UNIVERSIDADE DE SÃO PAULO

INSTITUTO DE GEOCIENCIAS

\title{
O POTENCIAL DE APLICAÇÃO DE ESTÉRIL DA MINERAÇÃO DE AREIA, EM MOGI DAS CRUZES (SP), COMO MATÉRIA-PRIMA CERÂMICA E POZOLÂNICA
}

\author{
Márcia Mika Saito \\ Orientadora: Profa. Dra. Lília Mascarenhas Sant'Agostino
}

DISSERTAÇÃO DE MESTRADO

Programa de Pós-Graduação em Recursos Minerais e Hidrogeologia

\author{
SÃO PAULO \\ 2002
}




\title{
UNIVERSIDADE DE SÃO PAULO INSTITUTO DE GEOCIÊNCIAS
}

\section{O POTENCIAL DE APLICAÇÃO DE ESTÉRIL DA MINERAÇÃO DE AREIA, EM MOGI DAS CRUZES (SP), COMO MATÉRIA-PRIMA CERÂMICA E POZOLÂNICA}

\author{
MÁRCIA MIKA SAITO
}

Orientadora: Profa. Dra. Lília Mascarenhas Sant'Agostino

DISSERTAÇÃO DE MESTRADO

COMISSÃO JULGADORA

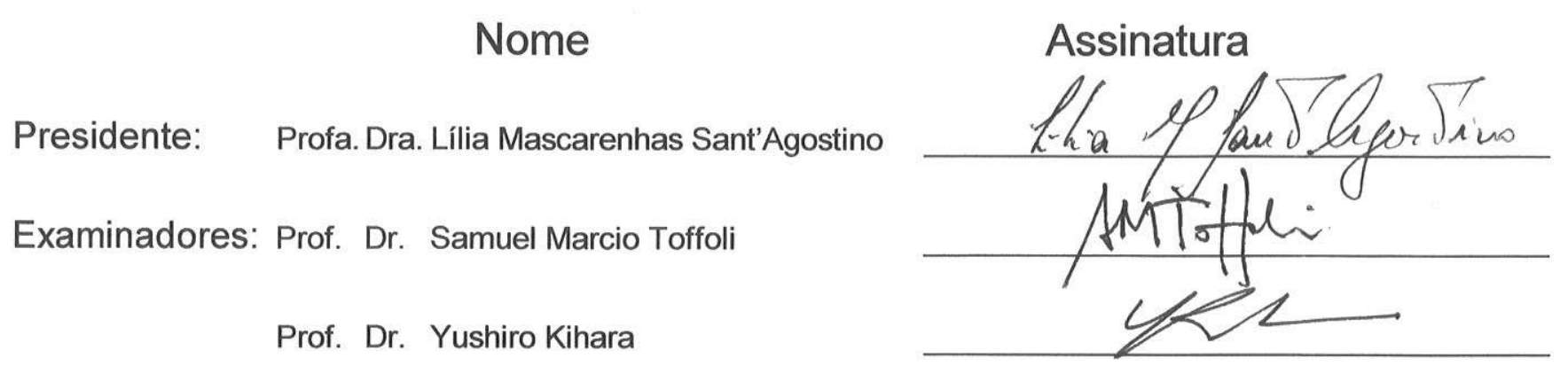

SÃO PAULO

2002 


\title{
UNIVERSIDADE DE SÃO PAULO INSTITUTO DE GEOCIÊNCIAS
}

O POTENCIAL DE APLICAÇÃO DE ESTÉRIL DA MINERAÇÃO DE AREIA, EM MOGI DAS CRUZES (SP), COMO MATÉRIA-PRIMA CERÂMICA E POZOLÂNICA .

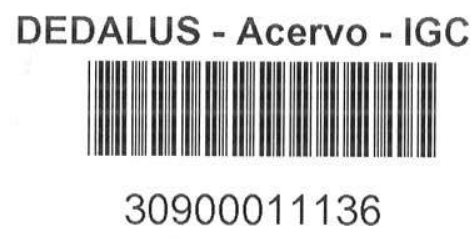

Márcia Mika Saito

Orientadora: Profa. Dra. Lília Mascarenhas Sant'Agostino

\section{DISSERTAÇÃO DE MESTRADO}

Programa de Pós-Graduação em Recursos Minerais e Hidrogeologia

\author{
SÃO PAULO \\ 2002
}


Ficha catalográfica preparada pelo Serviço de Biblioteca e Documentação do Instituto de Geociências da Universidade de São Paulo

\begin{tabular}{|l}
\hline Saito, Márcia Mika \\
o potencial de aplicação de estéril da \\
mineração de areia, em Mogi da Cruzes (SP), como \\
matéria prima cerâmica e pozolânica / \\
Márcia Mika Saito. - São Paulo, 2002. \\
172p. \\
Dissertação (Mestrado): IG/Usp - 2002 \\
Orient.: Sant'Agostino, Lília Mascarenhas \\
1. Mogi das Cruzes : Mineração de areia 2. \\
Cerâmica 3.Pozolana 4. Cimento I. Título. \\
\end{tabular}

$\begin{array}{r}\text { DOACAO SECAO DE POŚ- } \\ \text { GRADUACAO } \\ \hline \text { Data: } 21 / 10 / 02 \\ \hline\end{array}$


À minha família 


\section{RESUMO}

Este trabalho teve por objetivo apontar alternativas de uso aos estéreis da mineração de areia do Bairro do Taboão, em Mogi das Cruzes (SP), região responsável pela produção mensal de $170.000 \mathrm{~m}^{3}$ de areia, essencialmente consumida na Região Metropolitana de São Paulo.

Os estéreis, compostos por lamitos, lamitos arenosos e siltitos arenosos, representam de 30 a $50 \%$ do volume lavrado, e ocorrem como pacotes tabulares intercalados aos níveis arenosos explorados. O estéril tem impacto direto nos custos de produção, pelo volume movimentado, na vida útil da jazida, devido à ocupação de parte da área da jazida por bota-foras, e ainda sobre o meio ambiente, pela exposição desses materiais às intempéries.

Os lamitos apresentaram a composição mineralógica formada por esmectita $(50 \%)$, caulinita $(30 \%)$, illita $(15 \%)$ e outros minerais $(5 \%)$. Os lamitos arenosos e siltitos arenosos mostraram variações nas proporções de quartzo, caulinita e esmectita.

Amostras desses litotipos foram submetidas a ensaios de aplicação, com enfoque nos setores industriais de cerâmica estrutural e revestimento, e de cimento, visando o uso como pozolanas.

A caracterização cerâmica consistiu em determinação do índice de plasticidade e ensaios físicos em corpos-de-prova prensados e queimados à 950 e à $1.100^{\circ} \mathrm{C}$. Devido à composição mineralógica, as amostras apresentaram elevada plasticidade, característica que, em excesso, pode ser prejudicial ao processamento cerâmico, embora os produtos de queima em laboratório tenham mostrado resultados satisfatórios para uso em cerâmica estrutural e de revestimento.

A queima na temperatura $950^{\circ} \mathrm{C}$ resultou em produtos porosos, de cor avermelhada, com parâmetros de absorção de água e módulo de ruptura à flexão adequados para 
fabricação de tijolos furados e telhas. Os lamitos queimados à $1.100^{\circ} \mathrm{C}$ apresentaram os melhores resultados, atingindo características dos produtos grés e semi-grés.

A caracterização pozolânica foi realizada através da determinação dos índices de atividade pozolânica com cal e com cimento, utilizando lamitos e lamitos arenosos, em amostras naturais e calcinadas nas temperaturas $550,600,700$ e $850^{\circ} \mathrm{C}$.

As amostras naturais não se mostraram adequadas como pozolanas, devido ao caráter expansivo das esmectitas. Por outro lado, os índices de atividade pozolânica com cal obtidos para amostras calcinadas superaram o limite mínimo especificado pela norma brasileira, sendo os melhores resultados obtidos à $700^{\circ} \mathrm{C}$.

Os índices de atividade pozolânica com cimento, para as amostras ativadas à 550 e $600^{\circ} \mathrm{C}$, oscilaram em torno do limite mínimo especificado pela norma brasileira, sendo que temperatura ótima de ativação foi definida em $850^{\circ} \mathrm{C}$, com resultados superiores.

Os resultados obtidos indicaram que esses materiais apresentam grande potencialidade de aplicação nos setores industriais abordados, constituindo-se em matérias-primas estratégicas para uma demanda futura. 


\begin{abstract}
The aim of this study was research some alternative application for mining tailings from sand exploitation located at Bairro do Taboão in Mogi das Cruzes (SP). This district sand production is $170,000 \mathrm{~m}^{3} /$ month that is essentially consumed in the Great São Paulo Metropolitan Area.
\end{abstract}

The tailings, constituted by mudstones, sandy mudstones and sandy siltites, normally represent 30 to $50 \%$ of the total exploited volume. The tailings occur as tabular horizons intercalated with sandstone levels, affecting the production costs, due to its relative volume in the exploited material, the mineral reserves that are partially blocked by tailings stockpiles, and also the environment through the stockpiles powder material exposition to the weather.

Some samples of these litologies were submitted to specific application tests focussing ceramic production (common bricks, tiles and floor tiles) and as pozzolanic additive in cement manufacturing.

Mudstones are mineralogically composed by smectite $(50 \%)$, kaolinite $(30 \%)$, illite $(15 \%)$ and others accessories minerals (5\%). The sandy mustones and siltites showed mineral proportions variations, mainly of quartz, kaolinite and smectite.

The ceramic laboratory characterization was based on Atteberg limits (liquid and plastic limits) and physical parameters of pressed test specimens fired at $950^{\circ}$ and $1,000^{\circ} \mathrm{C}$. As a consequence of the mineral composition, the samples showed very high plasticity that can damage the ceramic process, even if the results, obtained using fired products, were satisfactory to application in common bricks and floor tiles ceramic.

The fired products obtained at $950^{\circ} \mathrm{C}$ were porous, reddish colored, and showed water absorption and bending strength suitable for common brick and tiles manufacturing. The 
best results were obtained to the mudstone fired at $1,100^{\circ} \mathrm{C}$ retrieving "gres" and "semigres" products characteristics.

To evaluate the behavior of the mudstone and sandy mudstone as pozzolan, some pozzolanic activity index were determined with lime and cement, using natural samples and calcined samples at $550,600,700$ and $850^{\circ} \mathrm{C}$.

The target materials are not able to be applied as natural pozzolans due to the expansive character of the smectites. On the other hand, the lime pozzolanic index obtained with calcined samples were in conformity with Brazilian specifications, the best burning temperature was $700^{\circ} \mathrm{C}$.

The cement pozolanic indices attained with the samples calcined at 550 and $600{ }^{\circ} \mathrm{C}$, reached the minimum specified in Brazilian norms, higher values were achieved for samples calcined at $850^{\circ} \mathrm{C}$, defining this temperature as the optimum.

The general results demonstrated that the material focused in this study have a great potentiality to be applied in the industrial segments covered, being a strategic raw material for future consumption. 


\section{AGRADECIMENTOS}

Gostaria de agradecer a todas as pessoas e instituições que me apoiaram e contribuiram para a realização deste trabalho.

À prof ${ }^{a} \mathrm{Dr}^{\mathrm{a}}$ Lília Mascarenhas Sant'Agostino, orientadora e amiga, pela sua dedicada orientação, compreensão, confiança, paciência e apoio fundamentais em todos os momentos.

À Carla Geanfrancisco, ao Sr. Ivo Damo e funcionários da empresa Cessi Comércio de Materiais para Construção Ltda., pela cessão de dados e apoio nos trabalhos de campo, coleta de amostras e viabilização de visitas às minerações de areia.

A FAPESP pela bolsa de mestrado concedida e financiamento de auxilio à pesquisa (Projetos: 99/9116-2 e 01/11358-3)

Ao prof. Samuel Márcio Toffoli e funcionários do Laboratório de Matérias-Primas Particuladas e Sólidos Não-Metálicos - LMPSol, Wilson, Valquíria e Denise, pela cessão de equipamentos e orientação na realização dos ensaios cerâmicos.

Aos funcionários da Associação Brasileira de Cimento Portland - ABCP, Flávio Munhoz, Vanini Perez e Celina, por promover as condições de execução dos ensaios pozolânicos.

Aos geólogos amigos Tarcísio José Montanheiro e Raquel Valério de Sousa Florêncio pelas importantes sugestões e críticas, que seguramente serviram para enriquecer o trabalho.

Aos professores Yushiro Kihara e Jorge Silva Bettencourt pelas sugestões e discussões.

Ao técnico Silvio Luiz Pereira pela inestimável ajuda na preparação de amostras.

Aos técnicos do IGc-USP, Flávio M. S. Carvalho (DRX), Paulo Mori (Florescência de raios $X$ ), Arthur (CPGeo), e os funcionários, Marquinhos (Manutenção), Luceir (seção polida).

Agradeço aos amigos George de Barros, Alexandre Carnier, Lucelene Martins, Marcelo Monteiro da Rocha, Ivo Trosdtorf Jr., Gláucia Cuchierato, Luciano Gobbo, Valéria Guimarães, Neide Y. Watanabe, Sílvia Cremonez, Cristiane L. Rodrigues, Iraldo, Cláudio Pires Florêncio, Irena Sparrenberger, Claudia Varnier, Sibele Ezaki e Alessandro Cesarino, que sempre estiveram prontamente dispostos a colaborar em todas as fases do trabalho.

Aos geólogos Marcos Souza Campos, Marcelo Fisher Gramani, Lucy Gomes Sant'Anna, Sônia A. Nogueira, Sergio Vicente Liotte, Francisco Motta e Luciana Maria Ferrer pela colaboração em diferentes etapas do trabalho.

Agradeço à minha família pelo apoio, compreensão e solidariedade em todos os momentos. 


\section{SUMÁRIO}

CAPITULO I-INTRODUCÃO

1. INTRODUÇÃO

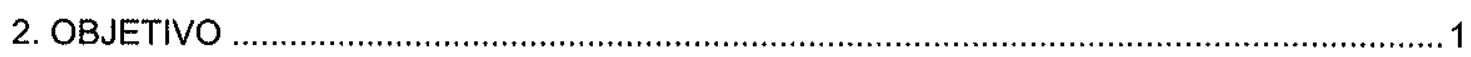

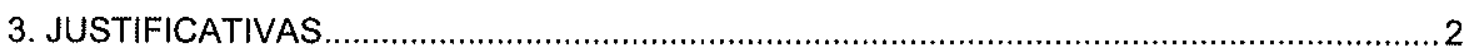

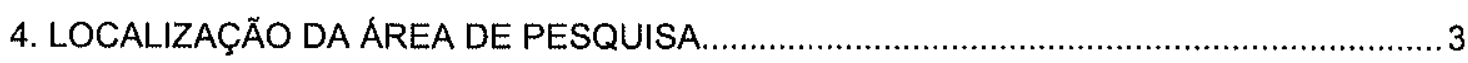

CAPITULO II-CONTEXTO GEOLÓGICO 4

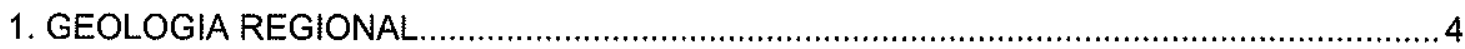

2. GEOLOGIA LOCAL

CAPÍTULO III-MINERACCÕES DE AREIA DE MOGI DAS CRUZES (SP) 11

1. A PRODUÇÃO DE AREIA DA REGIÃO DE MOGI DAS CRUZES …................................11

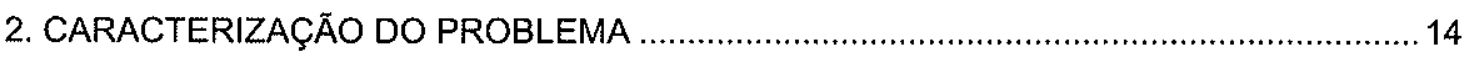

2.1 Estudo de caso: Mineração Cessi, Mogi das Cruzes (SP) ......................................... 18

CAPÍTULOIV-ARGILAS E SEUS USOS INDUSTRIAIS $\quad 24$

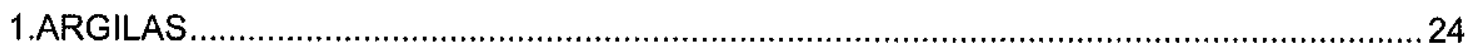

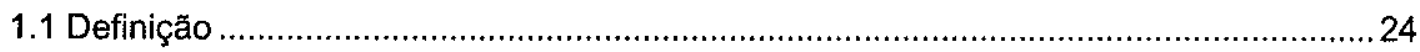

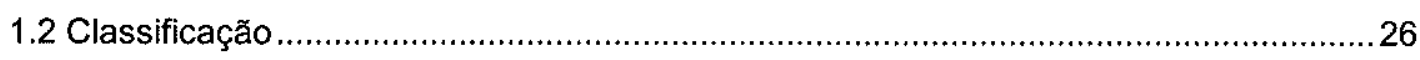

2. AS ARGILAS ESMECTITICAS DA BACIA DE TAUBATÉ (SP)

TRABALHOS ANTERIORES COM ENFASE NA APLICAÇÃO INDUSTRIAL ......................27

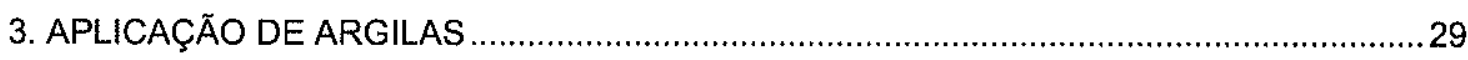

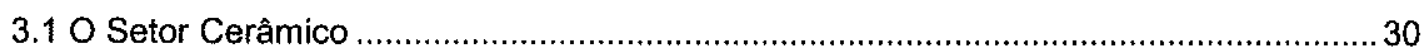

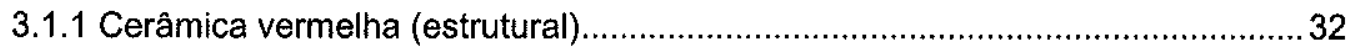

3.1.1.1 Argilas para cerâmica vermelha $\quad 32$

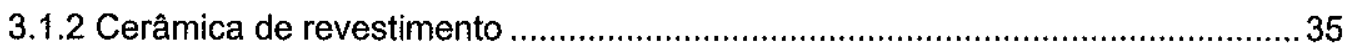

3.1.2.1 Argilas para cerâmica de revestimento .................................................. 37

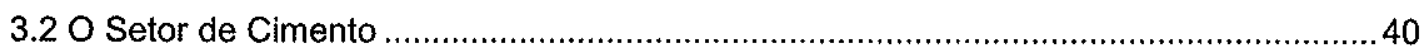

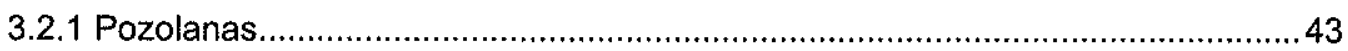

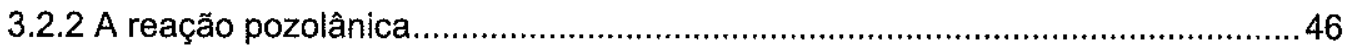

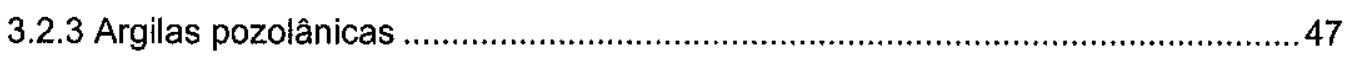

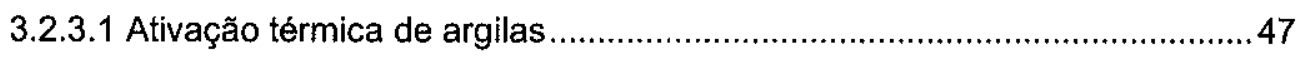

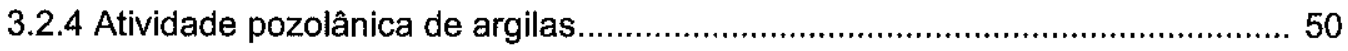

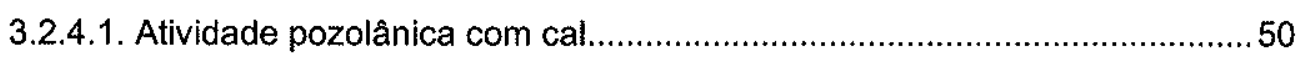

3.2.4.2. Atividade pozolânica com cimento...........................................................53 
1. LEVANTAMENTO BIBLIOGRÁFICO

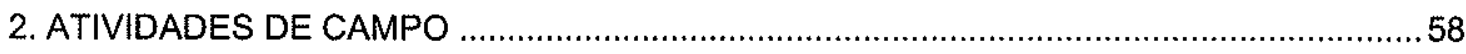

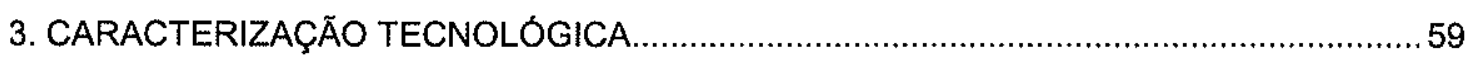

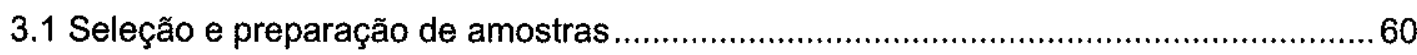

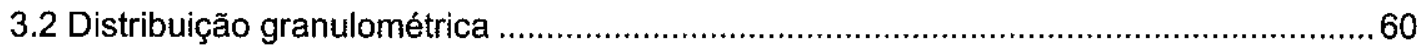

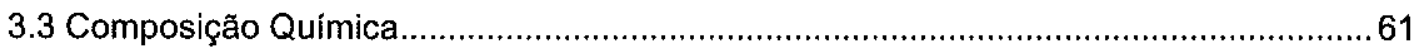

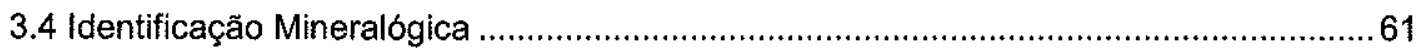

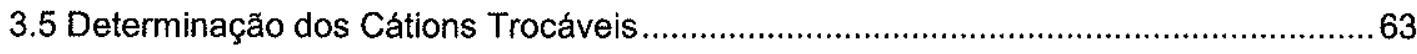

3.6 Análises Térmica Diferencial e Termogravimétrica .....................................................64

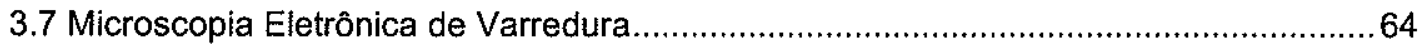

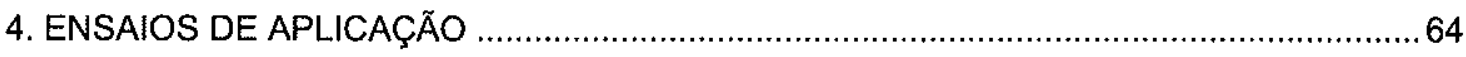

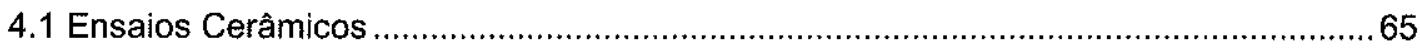

4.1.1 Determinação dos Limites de Liquidez e Plasticidade........................................65

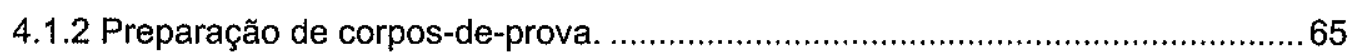

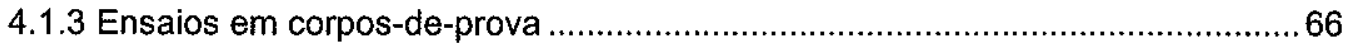

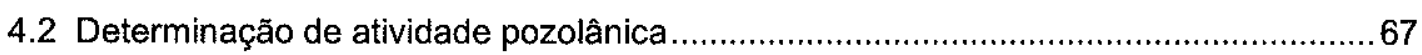

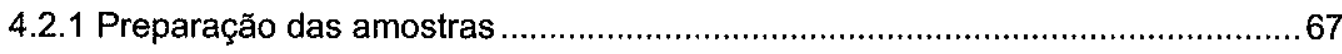

4.2.2 Indice de atividade pozolânica com cal - NBR 5751/92 .................................68

4.2.3 Indice de atividade pozolânica com cimento - NBR 5752/92 …........................69

\section{CAPÍTULO VI-RESULTADOS OBTIDOS NAS ATIVIDADES DE} CAMPO E NA CARACTERIZAÇÃO TECNOLÓGICA $\quad 70$

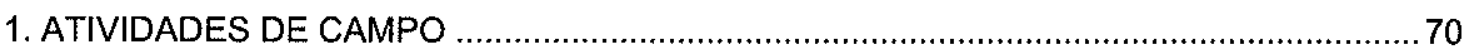

2. CARACTERIZAÇÃO TECNOLOGICA

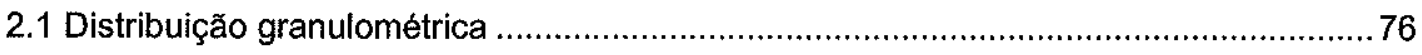

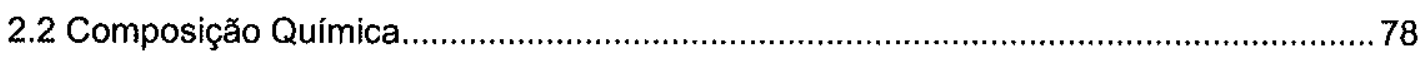

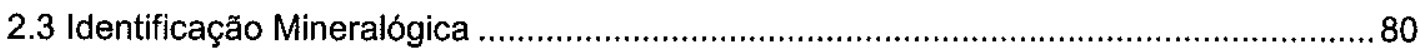

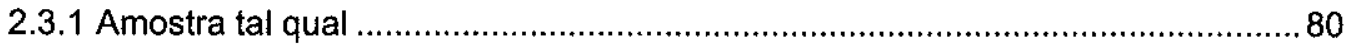

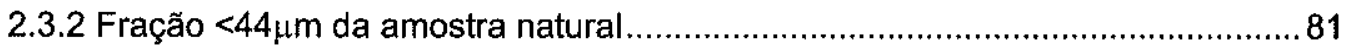

2.3.3 Fração $<2 \mu \mathrm{m}$ para identificação dos argilominerais ......................................... 85

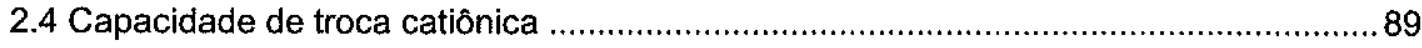

2.5 Análises termodiferencial (ATD) e termogravimétrica (ATG) ......................................91

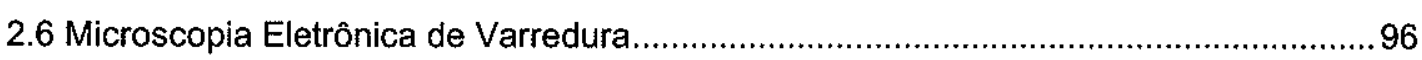

2.7 Quantificação das fases mineralógicas ................................................................ 100 


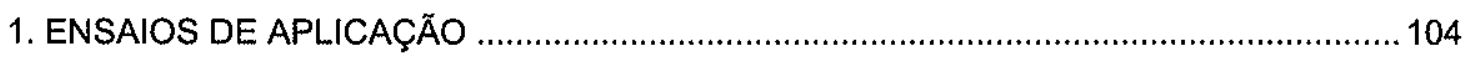

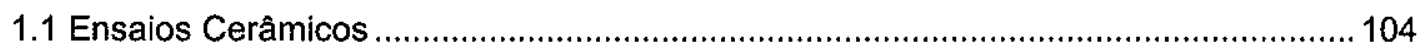

1.1.1 Limites de Atteberg - Limites de Liquidez e Plasticidade ............................... 104

1.1.2 Ensaios físicos nos corpos-de-prova pré queima ........................................ 108

1.1.3 Ensaios físicos em corpos-de-prova pós queima .......................................... 109

1.1.4 Considerações gerais sobre os ensaios cerâmicos......................................... 113

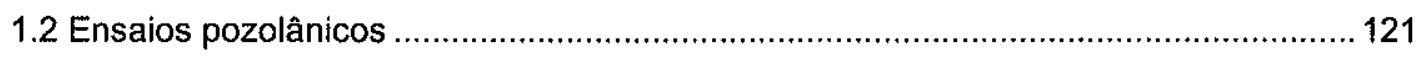

1.2.1 Índice de atividade pozolânica com cal ......................................................123

1.2.2 Índice de atividade pozolânica com cimento .............................................. 130

1.2.3 Considerações gerais sobre os ensaios pozolânicos ......................................1 133

CAPÍTULO VIII - CONCLUSÕES $\quad 136$

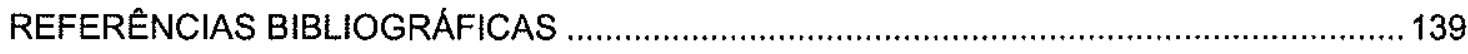

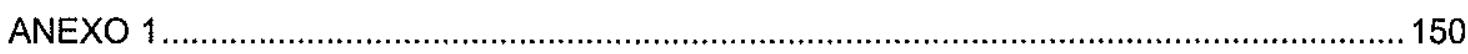

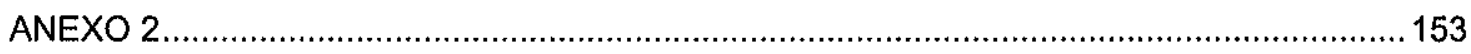

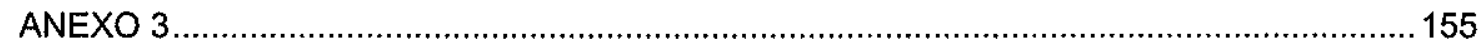

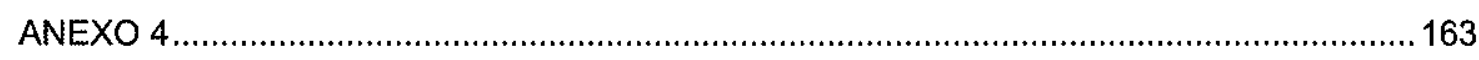




\section{Lista de Figuras}

Figura 1.1: Mapa de localização da área de pesquisa

Figura 2.1: Quadro tectono-estratigráfico do Rift Continental do Sudeste do Brasil RCSB (Riccomini et al., 1996)

Figura 2.2: Mapa geológico da região de Mogi das Cruzes (adaptado de Sant'Anna, 1999).

Figura 3.1: Mapa geológico da região do Bairro do Taboão em Mogi das Cruzes e Guararema (adaptado de Sant'Anna, 1999)

Figura 3.2: Mapa de potencialidade de areia (adaptado de Valverde et al., 1997) ........................ 17

Figura 3.3: Fluxograma de beneficiamento de areia na empresa Mineração Cessi, com os produtos, residuos e as respectivas destinações.

Figura 3.4: Capeamento da Cava 1 mostrando as intercalações de litotipos da Formação Resende, na Mineração Cessi

Figura 4.1: Organização estrutural dos átomos formadores de folhas tetraédricas e octaédricas; organização de camadas dioctaédricas e trioctaédricas; arranjos em estruturas 1:1 e 2:1, e exemplos de filossilicatos (adaptado de Velde, 1992).

Figura 4.2: Localização das fábricas de cimento no Brasil (adaptado de SNIC, 2002)...

Figura 4.3: Produção nacional de Cimento Portiand Comum e Composto (CP I+CP II) e Cimento Portland Pozolânico CP IV (extraído de SNIC, 1998, 1999, 2000)

Figura 4.4: Comportamento térmico de argilominerais (baseado em dados de SmyktazKloss, 1974).

Figura 4.5: Índices de Atividade Pozolânica com Cal aos 28 dias de cura para diferentes tipos de argilas. A região em verde representa conformidade com a norma NBR12653/92 (ABNT, 1992a).

Figura 4.6: Índice de Atividade Pozolânica com cimento aos 28 dias de cura para argilas naturais e calcinadas (He et al., 1995a). A região em verde representa conformidade com a norma ABNT NBR12653/92 (1992a).

Figura 4.7: Indice de atividade pozolânica com cimento aos 28 dias para diferentes argilas naturais e calcinadas. A região em verde representa conformidade com a norma NBR12653 (ABNT, 1992a) ....................................................................5

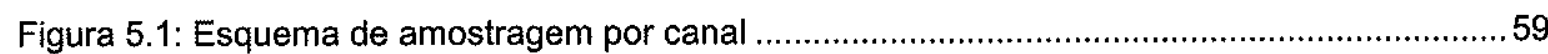

Figura 5.2: Fluxograma adotado para caracterização tecnológica ................................................60

Figura 5.3: Fluxograma dos métodos empregados para as análises por difração de raios $X$ de amostras naturais

Figura 5.4: Fluxogramas de preparação de amostras para difração de raios $X$ : (a) ensaios cerâmicos e (b) pozolanicidade

Figura 6.1: Planta esquemática da Mineração Cessi, Mogi das Cruzes (SP) ................................71

Figura 6.2: Seção geológica $A^{\prime}-A$ com a localização dos pontos de amostragem $e$ descrição simplificada dos intervalos amostrados

Figura 6.4: Distribuição granulométrica acumulada para as 17 amostras selecionadas ..................76

Figura 6.5: Diagrama triangular de Folk (1974) para classificação de rochas sedimentares

Figura 6.6: Difratogramas para amostras naturais: C6V (lamito arenoso), C11 e C19 (lamitos)

Figura 6.7: Difratograma da fração $<44 \mu \mathrm{m}$ da amostra C5A (lamito) ........................................... 82

Figura 6.8: Difratograma da fração $<44 \mu \mathrm{m}$ da amostra $\mathrm{C} 11 \mathrm{~B}$ (lamito) ......................................... 82

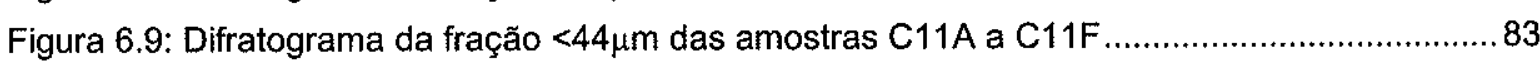

Figura 6.10: Difratograma da fração $<44 \mu \mathrm{m}$ das amostras C19AB e C19CD .............................. 83 
Figura 6.11: Difratograma da fração $<44 \mu \mathrm{m}$ da amostra C2S (lamito arenoso) 84

Figura 6.12: Difratograma da fração $<44 \mu \mathrm{m}$ da amostra C6V (lamito arenoso) ............................... 84

Figura 6.13: Difratograma da fração $<44 \mu \mathrm{m}$ da amostra $\mathrm{C} 13 \mathrm{~A}$ (siltito arenoso) 85

Figura 6.14: (a), (b) e (c) Difratogramas das frações $<2 \mu \mathrm{m}$ com identificação de grupos de argilominerais.

Figura 6.15: Difratogramas da fração $<2 \mu \mathrm{m}$ de amostra tal qual com determinação das espécies de argilominerais. (GL - glicerol; EG - etilenoglicol)

Figura 6.16: Difratogramas da fração $<2 \mu \mathrm{m}$ da amostra tal qual $\mathrm{C} 11$ natural, glicolada $\mathrm{e}$ aquecida a $550^{\circ} \mathrm{C}$

Figura 6.17: Capacidade de troca catiônica dos argilominerais (Grim, 1968) comparada com as amostras de lamitos e siltitos (os pontos laranja representam as médias das amostras)

Figura 6.18: (a) e (b) Curvas de ATD e ATG para amostras de lamito C11 e C19 (tal qual)

Figura 6.19: Curvas de ATD e ATG para amostra de lamito C5A (tal qual) e curva de DTG (derivada termogravimétrica)

Figura 6.20: Curvas de ATD e ATG para amostra de lamito arenoso C6V (tal qual) e curva de DTG (derivada termogravimétrica)

Figura 7.1: Estados de consistência e suas fronteiras (adaptado de Caputo, 1975)..................... 105

Figura 7.2: Diagrama de Casagrande, segundo Gippini (1969)................................................ 106

Figura 7.3: Diagrama de Bain (1986).

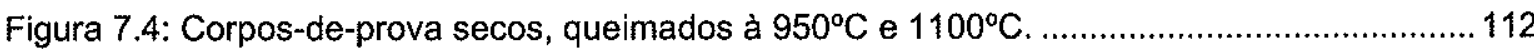

Figura 7.5: Perfil dos corpos-de-prova secos, queimados à $950^{\circ} \mathrm{C}$ e $1100^{\circ} \mathrm{C} \ldots \ldots \ldots \ldots \ldots \ldots \ldots \ldots . . . \ldots . \ldots . \ldots . .112$

Figura 7.6: Histograma de distribuição de freqüências para os coeficientes de correlação para as temperaturas de queima de $950^{\circ} \mathrm{C}$ e $1100^{\circ} \mathrm{C}$

Figura 7.7: Diagrama ternário com MRFXAAxRQ para temperatura de $1100^{\circ} \mathrm{C}$, mostrando a influência da tipologia do material nas propriedades cerâmicas (resultados recalculados para $100 \%$ ).

Figura 7.8: (a) Classificação dos produtos de queima, segundo Souza Santos (1989), baseada em absorção de água e módulo de ruptura à flexão, para corpos-deprova conformados por prensagem. (A seta representa a linha de tendência obtida para o conjunto de dados); (b) Diagrama simplificado de Casagrande, segundo Gippini (1969), com os dados de limite de liquidez e índice de plasticidade; (c) Diagrama de Bain (1986).

Figura 7.9: Classificação dos produtos de queima conforme recomendação da NBR13817 (ABNT, 1997), baseada em absorção de água e módulo de ruptura à flexão, para conformação por extrusão e por prensagem. (As setas representam as linhas de tendência obtidas para o conjunto de dados)

Figura 7.10: Curva termodiferencial típica das amostras esmectiticas estudadas (C11) ............ 122

Figura 7.11: Resultados de resistências mecânicas (índice de atividade pozolânica com cal) para amostras naturais e calcinadas

Figura 7.12: Difratogramas das amostras $\mathrm{C} 6 \mathrm{~V}$ e $\mathrm{C} 11$ na forma natural, calcinadas à 600 e $850^{\circ} \mathrm{C}$.

Figura 7.13: Influência da área especifica e da massa específica sobre a resistência mecânica em funçăo da temperatura de ativação

Figura 7.14: Resultados dos índices de atividade pozolânica em função da temperatura de ativação dos lamitos

Figura 7.15: Índices de atividade pozolânica com cal ( 7 dias de cura), com cimento (28 dias de cura) e curva termodiferencial do lamito (exemplo C11)... 


\section{Lista de Pranchas}

Prancha 3.1: Etapas do processo de extração e beneficiamento de areia: (1) Desmonte hidráulico; (2) Draga de bombeamento de polpa arenosa; (3) Peneira estática $(19,0 \mathrm{~mm})$ - lavagem da areia e bombeamento para relavagem; (4) Peneira estática (12,7 mm); (5) Relavagem da areia; (6) Classificação de areia em três faixas granulométricas (grosso, médio e fino); (7) Vista frontal das caixas de classificação; (8) Expedição dos produtos finais.

Prancha 3.2: Formas de ocorrência dos lamitos e utilização atual dos lamitos na Mineração Cessi: (1) nivel de lamito na base da Cava 1; (2) nível de lamito de $6 \mathrm{~m}$ de espessura na Cava 2;(3) material de decapeamento: deposição em bota-fora e; (4) material proveniente de desmonte hidráulico: manutenção da bacia de decantação. Diâmetro aproximado da bacia de decantação T1: $300 \mathrm{~m}$.

Prancha 6.1: Cava 1 da Mineração Cessi: (1) frente de lavra atual; (2) nivel lamítico (amostra C5A); (3) nivel lamítico arenoso (amostra C6V); (4) operação de decapeamento do nível lamítico arenoso; (5) desmonte hidráulico...

Prancha 6.2: Cava 2 da Mineração Cessi: (1) frente de lavra atual; (2) desmonte hidráulico; (3) e (4) nivel de lamito presente na base da cava 2 - pontos de amostragem $(C 9,10$ e 11) - espessura total do nível lamítico: $6 \mathrm{~m}$.

Prancha 6.3: Imagens ao microscópio eletrônico de varredura (MEV - sinal de elétrons secundários) da amostra C6V tal qual e fração $<2 \mu \mathrm{m}$ : (a) aspecto geral da matriz argilosa e espectro de EDS mostrando composição illítica (?) na área circundada: (b) aspecto geral da matriz lamítica; (c) argilominerais da fração $<2 \mu \mathrm{m}$; (d) argilominerais da fração $<2 \mu \mathrm{m}$ com espectro de EDS determinado na área circundada, mostrando a composição caulinítica

Prancha 6.4: Imagens ao microscópio eletrônico de varredura (MEV - sinal de elétrons secundários) da amostra $\mathrm{C} 11$ tal qual e fração $<2 \mu \mathrm{m}$ : (a) aspecto geral da matriz argilosa e espectro de EDS mostrando composição illítica (?) na área circundada: (b) detalhe da matriz lamítica e espectro de EDS mostrando uma composição caulinítica; (c) aspecto geral dos argilominerais; (d) argilominerais da fração $<2 \mu \mathrm{m}$ com espectro de EDS determinado na área circundada, mostrando a composição esmectítica.

Prancha 6.5: Imagens ao microscópio eletrônico de varredura (MEV - sinal de elétrons secundários) da amostra C19 tal qual: (a) aspecto geral da matriz argilosa e espectro de EDS mostrando composição esmectitica (?) na área circundada: (b) aspecto geral da matriz lamítica; (c) aspecto geral da matriz lamítica e espectro de EDS mostrando uma composição caulinítica; (d) argilominerais com espectro de EDS determinado na área circundada, mostrando a composição esmectítica

Prancha 7.1: Imagens obtidas ao microscópio eletrônico de varredura, utilizando elétrons secundários e difratogramas de raios $\mathrm{X}$ para a amostra $\mathrm{C} 6 \mathrm{~V}$ em estado natural, após queima à $950^{\circ} \mathrm{C}$ e $1100^{\circ} \mathrm{C}$.

Prancha 7.2: Imagens de microscopia eletrônica de varredura: (a) Fase neoformada a partir da reação pozolânica (placóide - gehlenita ?; rendilhado - $\mathrm{CSH}$ ), com espectro de EDS para o ponto circundado; (b) material rendilhado recobrindo as placas de argilominerais; (c) difratogramas de raios $X$ obtidos para amostras em estado natural e das misturas amostra+hidróxido de cálcio para as temperaturas de $600 \mathrm{e}$ $850^{\circ} \mathrm{C}$ (amostra $\mathrm{C} 6 \mathrm{~V}+\mathrm{Ca}(\mathrm{OH}) 2$ aos 7 dias de cura).

Prancha 7.3: Imagens de microscopia eletrônica de varredura: (a) Fase neoformada a partir da reação pozolânica (placóide - gehlenita ?; rendilhado - $\mathrm{CSH}$ ), com espectro de EDS para o ponto circundado; (b) material rendilhado recobrindo as placas de argilominerais, com espectro de EDS para o ponto circundado; (c) difratogramas de raios $\mathrm{X}$ obtidos para amostras em estado natural e para as misturas amostrathidróxido de cálcio para as temperaturas de 600 e $850^{\circ} \mathrm{C}$; (d) aspecto geral da pasta cal/pozolana (amostra $\mathrm{C} 11+\mathrm{Ca}(\mathrm{OH})_{2}$ aos 7 dias de cura). 


\section{Lista de Tabelas}

Tabela 3.1: Situação legal dos processos para a substância areia nos municípios de Mogi das Cruzes e Guararema (DNPM-SICOM, 29 de abril de 2002) ...

Tabela 3.2: Principais minerações de areia da região de Guararema/Mogi das Cruzes ................. 15

Tabela 3.3: Potencialidade das sub-áreas relativas ao Bairro do Taboão em Mogi das Cruzes e Norte de Guararema (Valverde et al., 1997).

Tabela 3.4: Dados de produção da empresa Cessi Materiais para Construção Ltda., em março de 2001

Tabela 4.1: Classificação dos filossilicatos com ênfase em argilominerais ( $\mathrm{Tr}-$ trioctaédricos; $\mathrm{Di}$ - dioctaédricos), segundo Moore \& Reynolds (1997) …....................2 27

Tabela 4.2: Aplicações industriais de algumas argilas (Murray, 1991; 2000) .................................29

Tabela 4.3: Panorama setorial dos principais segmentos cerâmicos ................................................. 31

Tabela 4.4: Compilação bibliográfica de resultados cerâmicos para argilas de diferentes composições extrudadas.

Tabela 4.5: Especificação técnica para blocos cerâmicos extrudados, segundo NBR 7171/83 (ABNT, 1983) e absorção de água, segundo IPT (apud Florêncio, 1999).

Tabela 4.6: Valores recomendados para matérias-primas cerâmicas, obtidos em ensaios realizados em laboratório (Souza Santos, 1989).

Tabela 4.7: Especificação para placas cerâmicas de revestimento segundo a absorção de água (AA) (NBR 13818 - ABNT, 1997b) e produto acabado, segundo CCB (1998)

Tabela 4.8: Compilação bibliográfica de resultados cerâmicos para argilas de diferentes composições prensadas

Tabela 4.9: Composição dos Cimentos Portland Comum, Composto e Pozolânico

Tabela 4.10 - Especificações químicas e físicas para materiais pozolânicos (NBR $12653 / 92$ - ABNT, 1992a)

Tabela 4.11 Vantagens tecnológicas, econômicas e ambientais atribuídas ao uso de pozolanas.

Tabela 4.12: Fases e fórmulas produzidas durante a reação pozolânica.

Tabela 4.13: Atividade pozolânica com cal $\left(\mathrm{Ca}(\mathrm{OH})_{2}\right)$, após 28 dias de cura, relação pozolana/cal=1 (células em cinza representam amostras com maiores conteúdos de esmectita).

Tabela 4.14: Indices de atividade pozolânica com cimento aos 28 dias de cura para argilas calcinadas (em cinza, amostras com esmectita).....

Tabela 5.1: Tratamentos para identificação dos argilominerais (para fração $<2 \mu \mathrm{m}$ ), segundo Thorez (1976); Moore \& Reynolds (1997)

Tabela 5.2: Fórmulas para determinação dos parâmetros físicos dos corpos-de-prova ...................67

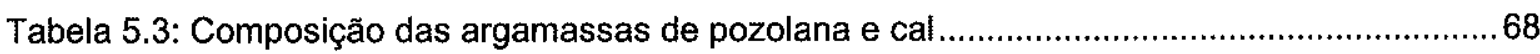

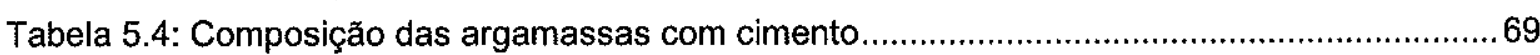

Tabela 5.5: Fórmula para a determinação do indice de atividade pozolânica..................................69

Tabela 6.1: Sumário das atividades de caracterização tecnológica e ensaios de apłicação

Tabela 6.2: Classificação das amostras segundo mediana $\left(D_{50 \%}\right)$, Shepard (1954) e Folk (1974).

Tabela 6.3: Composição química das amostras segundo os litotipos (\% em peso dos óxidos)

Tabela 6.4: Capacidade de troca cationica calculada das 17 amostras

Tabela 6.5: Temperaturas iniciais (To) e finais (Tc) para as transformações térmicas e variações de massa $(\Delta \%)$ 
Tabela 6.6: Composições químicas illita e caulinita ......................................................................... 101

Tabela 6.7: Composição química anidra para esmectita, illita e caulinita....................................... 101

Tabela 6.8: Composição química anidra dos óxidos $\mathrm{SiO}_{2 \text { total, }} \mathrm{SiO}_{2}$ livre e $\mathrm{SiO}_{2}$ ligado à

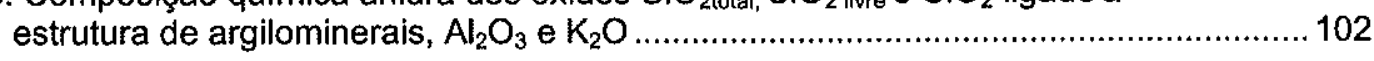

Tabela 6.9: Resultados de quantificação mineralógica para as amostras .................................... 103

Tabela 7.1: Amostras selecionadas para os ensaios ceråmicos. ................................................. 104

Tabela 7.2: Resultados obtidos para os limites de liquidez e plasticidade, e índice de

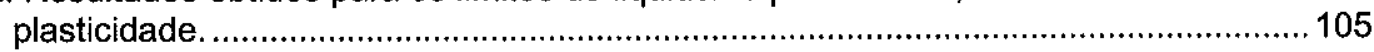

Tabela 7.3: Resultados de ensaios físicos nos corpos-de-prova a seco. .....................................109

Tabela 7.4: Resultados dos ensaios físicos nos corpos-de-prova queimados à $950^{\circ} \mathrm{C} \ldots \ldots \ldots \ldots \ldots \ldots \ldots . . . \ldots 10$

Tabela 7.5: Resultados dos ensaios físicos nos corpos-de-prova queimados à $1100^{\circ} \mathrm{C} \ldots \ldots \ldots \ldots \ldots \ldots . . . . . .111$

Tabela 7.6: Matriz de correlação entre propriedades cerâmicas e características naturais das matérias-primas para produtos de queima à $950^{\circ} \mathrm{C} \ldots \ldots \ldots \ldots \ldots \ldots \ldots \ldots . . . . . . . .114$

Tabela 7.7: Matriz de correlação entre propriedades cerâmicas e características naturais das matérias-primas para produtos de queima à $1100^{\circ} \mathrm{C}$............................. 116

Tabela 7.8: Reações e transformações térmicas de amostras de lamitos e lamito arenoso.

Tabela 7.9: Amostras selecionadas para as determinações de atividade pozolânica com cal e

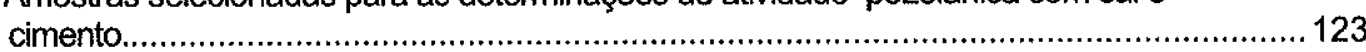

Tabela 7.10:Propriedades físicas das amostras naturais e calcinadas. ..................................... 123

Tabela 7.11:Composição das argamassas para a determinação de atividade pozolânica com cal aos 7 dias de cura.................................................................124

Tabela 7.12:Índice de atividade pozolânica com cal aos 7 dias de cura. ..................................... 124

Tabela 7.13:Caracterização física dos materiais pozolânicos e do cimento utilizado nos

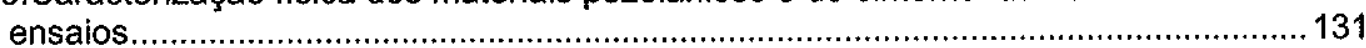

Tabela 7.14:Composição das argamassas com cimento Portland. ............................................ 131

Tabela 7.15:Resultados das determinações da atividade pozolânica com cimento aos 28 dias de cura.

Tabela 7.16: Enquadramento dos resultados obtidos nas especificações NBR 12653/92 (ABNT, 1992a). 135

\section{Lista de Siglas}

ABNT - Associação Brasileira de Normas Técnicas

ANEPAC - Associação Nacional das Entidades de Produtores de Agregados para Construção Civil

ANFACER - Associação Nacional dos Fabricantes de Cerâmica para Revestimento

$A B C$ - Associação Brasileira de Cerâmica

$A B C P$ - Associação Brasileira de Cimento Portland

CCB - Centro Cerâmico Brasileiro

CETESB - Companhia de Tecnologia de Saneamento Ambiental

DNPM - Departamento Nacional de Produção Mineral

SNIC - Sindicato Nacional das Indústrias de Cimento 


\section{CAPÍTULO I- INTRODUÇÃO}

\section{INTRODUÇÃO}

Este trabalho apresenta resultados de estudos de aplicação de estéreis lamíticos (sílticoargilosos), de composição esmectítica, provenientes de minerações de areia do Bairro do Taboão em Mogi das Cruzes (SP).

$\mathrm{Na}$ região são exploradas níveis arenosos que tipicamente encontram-se encobertos e intercalados com espessas camadas silto-argilosos (lamitos).

A remoção, mobilização e destinação de grandes volumes de material estéril na extração de areia torna o empreendimento pouco vantajoso, devido aos elevados custos de produção associados, além do esgotamento precoce das áreas úteis ocupadas por botaforas.

Buscou-se, através da caracterização tecnológica e ensaios específicos de aplicação, apontar algumas alternativas de uso desses materiais, enfocando dois segmentos industriais: cerâmico e cimento.

Foram executadas atividades de campo com visitas às empresas de mineração da região, acompanhamento da atividades produtivas, seleção de área alvo para a concentração dos trabalhos de amostragem, descrição geológica de frentes de lavra, tendo sido definida a Mineração Cessi para estudo de caso.

\section{OBJETIVO}

O objetivo deste trabalho foi caracterizar tecnologicamente resíduos (material estéril) de uma mineração de areia do distrito areieiro do Bairro do Taboão em Mogi das Cruzes (SP), de forma a apontar alternativas de uso industrial e com isso qualificar os resíduos a fim de obter um aproveitamento econômico, pela valoração do produto, e ambientalmente correto, por evitar estoques de material a céu aberto.

O equacionamento econômico associado à perspectiva de redução dos impactos ambientais visa contribuir para o desenvolvimento sustentável de empreendimentos hoje intensamente discriminados pela atuação dita agressiva ao meio ambiente. 


\section{JUSTIFICATIVAS}

O distrito areieiro do Bairro do Taboão em Mogi das Cruzes, localizado na porção oeste da Bacia de Taubaté, responde por $7 \%$ da demanda de areia da RMSP. Com produção mensal aproximada de $170.000 \mathrm{~m}^{3}$, a região conta com 17 empresas de mineração, a maioria instalada sobre sedimentos terciários da Formação Resende.

Os depósitos sedimentares da Formação Resende são caracterizados, nessa região, como intercalações métricas de arenitos, de granulação diversa, a conglomerados e níveis métricos de lamitos esverdeados, de composição esmectítica/caulinítica.

Os niveis lamíticos, que representam de 30 a $50 \%$ do volume total do depósito, são extraídos juntamente com a areia durante o desmonte das frentes de lavra. Atualmente parte desses materiais tem sido utilizada na elevação e manutenção de barragens de rejeitos, o restante é depositado em bota-foras que ocupam importantes parcelas do terreno.

Procurando alternativas para equacionamento do problema de destinação desses resíduos argilosos buscou-se investigar as características dos materiais com vistas à sua aplicação industrial em segmentos com grande potencial de consumo, especificamente a indústria cerâmica, como parte integrante das massas, e a indústria do cimento, como aditivo na forma de pozolana. 


\section{LOCALIZAÇÃO DA ÁREA DE PESQUISA}

O acesso a partir da capital de São Paulo é feito pela rodovia Presidente Dutra (BR 116) até o km 199 (saída para Arujá), de onde se segue pela rodovia Mogi-Dutra (SP 98) até o trevo de acesso à estrada do Taboão, próximo ao cruzamento com a rodovia Ayrton Senna (SP 70) e às instalações da General Motors do Brasil. Pode-se atingir o mesmo ponto através da rodovia Ayrton Senna (SP 70).

Prossegue-se pela estrada do Taboão por aproximadamente $5 \mathrm{~km}$, até atravessar o Ribeirão Maria Rosa fazendo-se, a seguir, uma conversão à esquerda, na estrada de terra que leva às instalações da Cessi Comércio de Materiais para Construção Ltda. e à área de pesquisa.

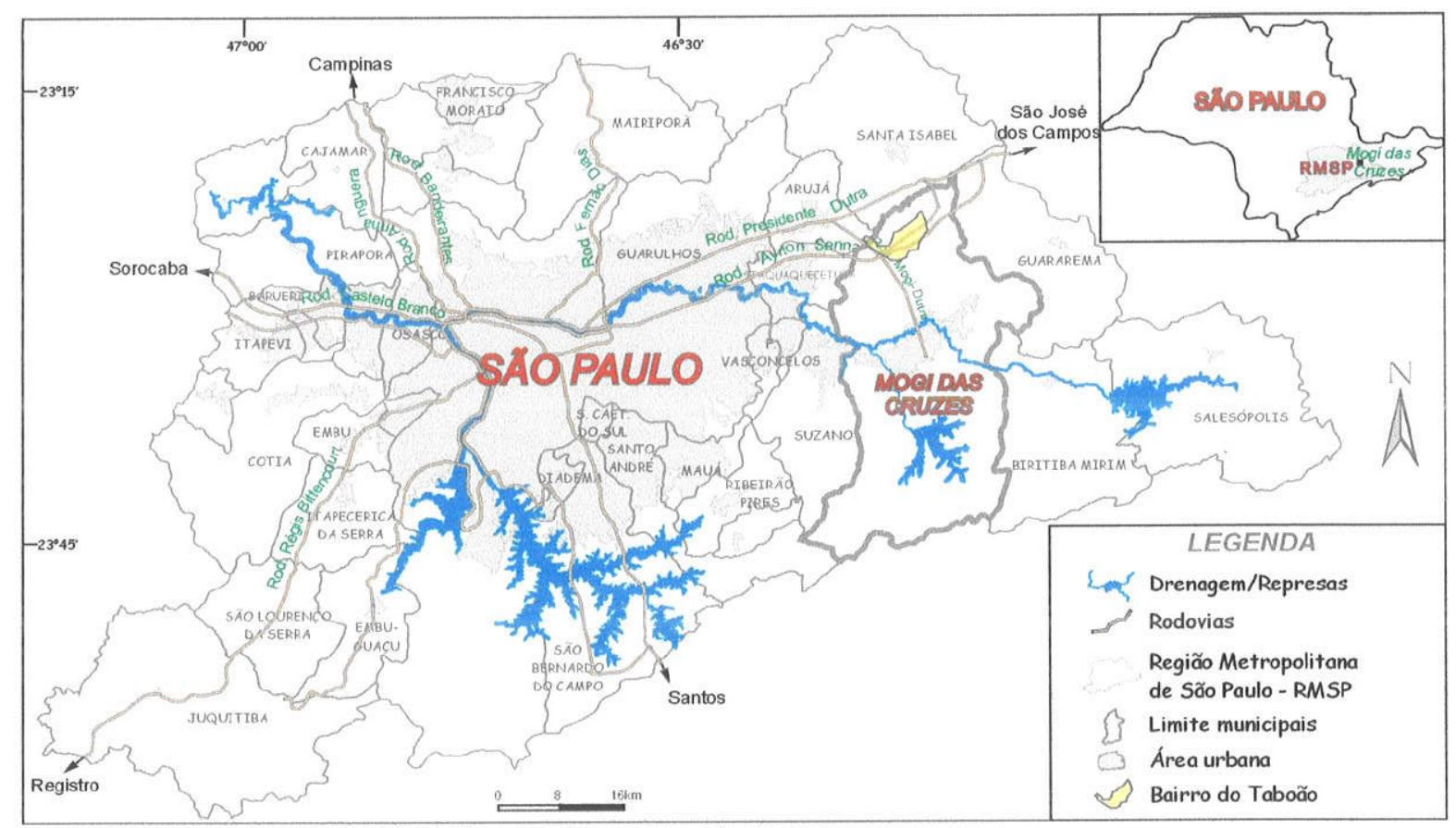

Figura 1.1: Mapa de localização da área de pesquisa. 


\section{CAPÍTULO II - CONTEXTO GEOLÓGICO}

\section{GEOLOGIA REGIONAL}

O arcabouço geológico da Região Metropolitana de São Paulo é constituído por terrenos policíclicos do Cinturão de Dobramentos Ribeira representados por rochas metamórficas, migmatitos e granitóides (Hasui et al., 1975). Sobre esses terrenos encontram-se depositados sedimentos cenozóicos das Bacias de São Paulo e Taubaté, que por vezes são sobrepostos por sedimentos aluviais e coluviais quaternários.

Os sedimentos cenozóicos, no Estado de São Paulo, encontram-se assentados sobre o embasamento pré-cambriano a eopaleozóico em bacias sedimentares que compõem o Rift Continental do Sudeste do Brasil - RCSB (Riccomini, 1989). O RCSB é uma feição tectônica de idade cenozóica, presente no extremo oriental da região sudeste do Brasil, disposta como uma faixa estreita e deprimida, alongada segundo a direção ENE, desenvolvendo-se entre as cidades de Curitiba (PR) e Barra de São João (RJ), numa extensão de quase $900 \mathrm{~km}$. No Estado de São Paulo, o RCSB engloba as Bacias de São Paulo (Região Metropolitana de São Paulo) e de Taubaté (parte da Região Metropolitana de São Paulo e Vale do Paraíba) (Sant'Anna, 1999).

Riccomini (1989) caracterizou os processos tectônicos e sedimentares, vigentes durante a evolução das bacias do RCSB, através de análises microestruturais e estudos de fácies e sistemas deposicionais, que foram apoiadas por dados mineralógicos, palinológicos, geocronológicos e geomorfológicos. O RCSB é composto na base pelo Grupo Taubaté, com as Formações Resende, Tremembé e São Paulo, e no topo pelas Formações Itaquaquecetuba e Pindamonhangaba, sobre os quais ocorrem sedimentos coluvionares recentes, produtos de eventos distintos da evolução tectônica da Bacia, conforme indicado no quadro tectonoestratigráfico da Figura 2.1. 


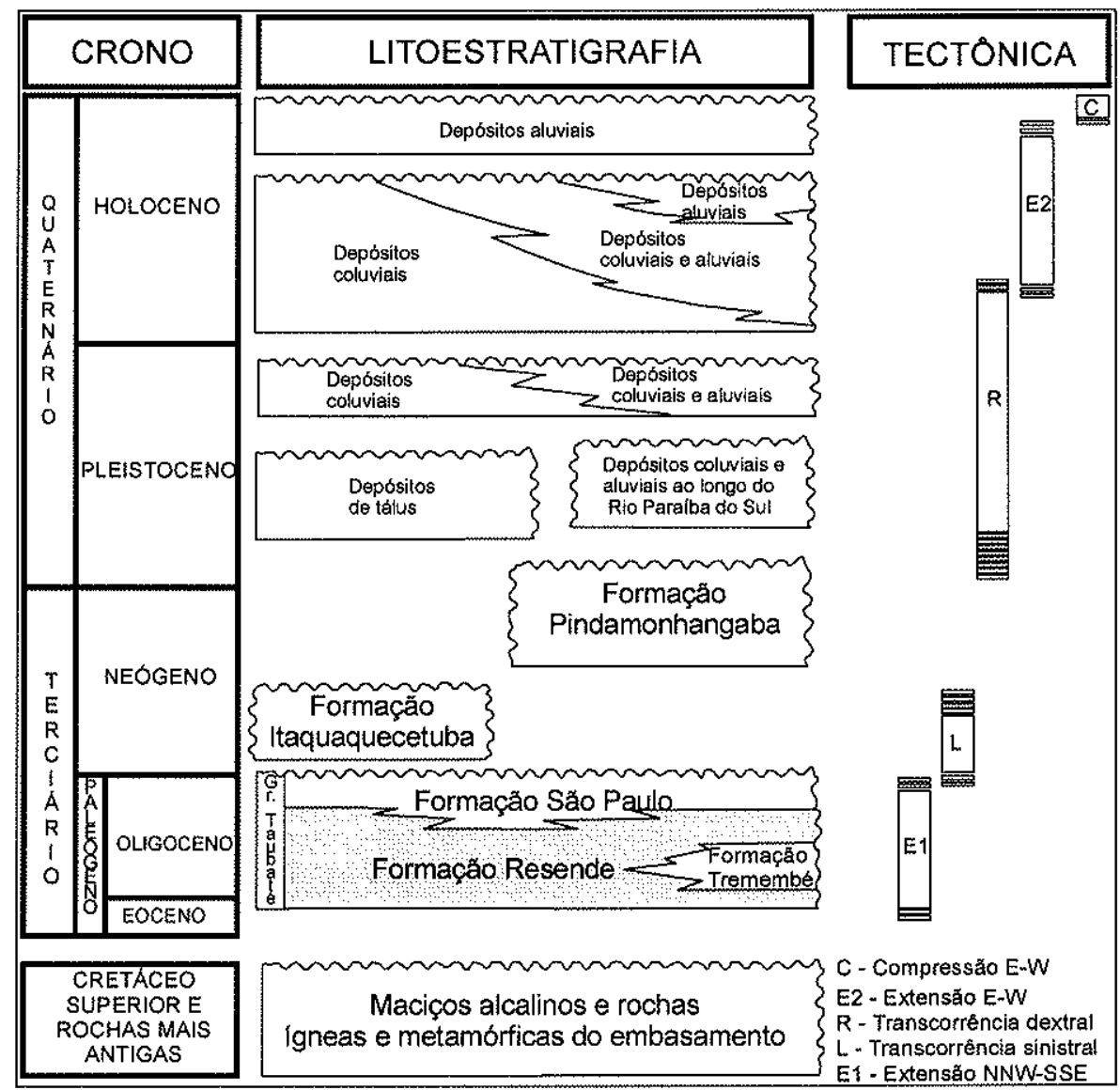

Figura 2.1: Quadro tectono-estratigráfico do Rift Continental do Sudeste do Brasil - RCSB (Riccomini et al., 1996)

Segundo Riccomini (1989), a seqüência de eventos que compõem o quadro evolutivo do RCSB em seu segmento mais contínuo, entre as cidades de São Paulo (SP) e Volta Redonda (RJ), é definida por:

a) Paleógeno (Eoceno-Oligoceno) - formação da depressão original (hemi-graben), produto do campo de esforços extensionais de direção NNE-SSE, com preenchimento vulcano-sedimentar sin-tectônico do Grupo Taubaté, que compreende um sistema de leques aluviais associados à planície aluvial de rios entrelaçados, com ocorrências nas porções basal e lateral da bacia (Formação Resende); um sistema playa-lake (Formação Tremembé); um sistema fluvial meandrante (Formação São Paulo); e eclosão de derrames de basanito restritos à porção sudeste de Volta Redonda (RJ). As Formações Resende e Tremembé foram depositadas em regimes climáticos semi-áridos, passando para úmidos durante a deposição da Formação São Paulo. 
b) Neógeno (Mioceno?) - implantação de um regime de esforços transcorrentes sinistral de direção NW-SE e localmente com compressão NE-SW. Periodo no qual foram formadas as soleiras de Arujá, Queluz, etc., responsáveis pela separação das drenagens dos rios Tietê e Rio Paraíba do Sul. A Formação Itaquaquecetuba foi depositada nessa época, restritamente à Bacia de São Paulo.

c) Plioceno (?) a Pleistoceno Inferior - deposição da Formação Pindamonhangaba em sistema fluvial meandrante, restritamente à Bacia de Taubaté.

d) Pleistoceno Superior - no início tectonicamente estável, com a deposição de sedimentos colúvio-aluvionares, seguido de nova fase de deformação, através de um sistema transcorrente E-W, com movimentação destral associada à compressão NW-SE e geração de novas soleiras, responsável pela configuração atual dos sedimentos.

e) Holoceno - instalação de um novo regime extensional NW-SE, definindo a rede de drenagem do Rio Paraíba do Sul.

f) Recente - modificação do campo de tensões, com vigência de um regime compressional.

A alternância entre os regimes compressionais e extensionais é atribuída à compensação entre as taxas de abertura na Cadeia Meso-Atlântica e de subducção da Placa de Nazca sob a Placa Sul Americana (Riccomini, 1989).

Dentre as formações terciárias que compõem o RCSB, a Formação Resende apresenta as maiores ocorrências superficiais (Figura 2.2). A esta formação pertencem os materiais de estudo deste trabalho, por isto será melhor detalhada.

A Formação Resende é caracterizada por sedimentos representativos de sistemas de leques aluviais associados a planícies aluviais de rios entrelaçados, cuja seção-tipo está exposta na rodovia Presidente Dutra, km 145 (Resende, RJ), tendo sido descrita inicialmente por Amador (1975). Segundo Riccomini et al. (1991b), a Formação Resende apresenta dois litofácies R1 e R2, respectivamente representativos das porções proximal e distal de um sistema de leques aluviais, cuja transição é observada na porção mediana, descrita como:

R1) Fácies de diamictitos e conglomerados polimíticos, com matriz lamítica arenosa arcoseana esverdeada, depositados por processos de fluxo gravitacional em sistema de 
leques aluviais proximais, com gradação normal ou inversa e acunhamento em direção ao eixo deposicional da bacia.

R2) Fácies de lamitos predominantemente arenosos e arenitos de coloração esverdeada, estes com estratificação cruzada acanalada de médio porte, e niveis conglomeráticos com seixos dominantemente de quartzo, quartzito, feldspatos e rochas do embasamento, apresentando gradação normal e inversa. Esses fácies ocorrem interdigitados aos conglomerados e diamictitos dos fácies descritos acima, constituindo corpos tabulares de espessuras métricas a decimétricas, representativos da sedimentação em planície aluvial de rios entrelaçados. Em alguns casos, os sedimentos arenosos ocorrem em meio a sedimentos síltico-argilosos (lamitos), podendo apresentar forma de extensos lençóis, com espessura não inferior a $1 \mathrm{~m}$, e estratificação cruzada acanalada, no topo dos lamitos.

Segundo Riccomini et al. (1991b), durante a deposição predominaram os processos de fluxo gravitacional de massa, com retrabalhamento em grau variado nas porções distais, passando localmente para a planície aluvial em sistema fluvial entrelaçado (braided). $\mathrm{Na}$ planície aluvial houve a formação dos niveis areníticos com estratificação cruzada, sendo que a estagnação de massas de água seria responsável pela diferenciação hidrodinâmica dos lamitos em corpos arenosos e siltico-argilosos.

Autores como Riccomini (1989), Brandt Neto et al. (1991), Riccomini et al. (1996), estudaram os sedimentos das unidades terciárias das bacias de Taubaté, Resende, Volta Redonda e São Paulo, visando definir composição, gênese e paleoambiente dos sedimentos, principalmente de esmectitas a eles associadas.

A origem das esmectitas teria sido condicionada pelo intemperismo químico sobre rochas gnáissicas, xistos e granitos do embasamento pré-cambriano. A hidrólise de feldspatos e micas teria fornecido os cátions necessários à formação de esmectitas, gerando produtos de alteração homogeneizados mineralógica e geoquimicamente, em escala regional. A principal época de geração desses paleossolos corresponde, provaveimente, ao Eoceno Inferior a Médio, quando as condições paleoclimáticas no sudeste brasileiro apresentavam tendência à aridez (clima temperado a semi-árido quente) (Sant'Anna, 1999).

A manutenção das condições paleoclimáticas no RCSB durante o Eoceno SuperiorOligoceno proporcionou o desenvolvimento de sistemas deposicionais desenvolvidos (leques aluviais associados a planícies de rios entrelaçados e lago do tipo playa-lake), bem como de rochas carbonáticas (calcretes e dolomitos) associadas a esses depósitos (Sant'Anna, 1999). 
A Formação São Paulo, de idade oligocênica superior (Lima et al. e Yamamoto apud Sant'Anna, 1999), compreende um sistema fluvial meandrante, caracterizado por arenitos grossos, conglomeráticos, com estratificações cruzadas, base erosiva e presença de clastos argilosos, representantes de depósitos de canais meandrantes; siltitos e argilitos laminados, às vezes, fossiliferos (linhitos), depositados em meandros abandonados; e arenitos médios a grossos como sedimentos de rompimento de diques marginais, gradando para sedimentos mais finos, rítmicos e laminados, de planície de inundação. A Formação São Paulo marca o término da sedimentação do Grupo Taubaté, num período de relativa calmaria tectônica (Riccomini, 1989).

Acima do Grupo Taubaté ocorrem as Formações Itaquaquecetuba (Coimbra et al., 1983; Riccomini \& Coimbra, 1992), representativa de um sistema fluvial entrelaçado com sedimentos restritos à Bacia de São Paulo, e Pindamonhangaba (Riccomini et al., 1991a; Riccomini, 1989; Mancini, 1995), correspondente a um sistema fluvial meandrante de ocorrência restrita à porção central da Bacia de Taubaté (Sant'Anna, 1999). 


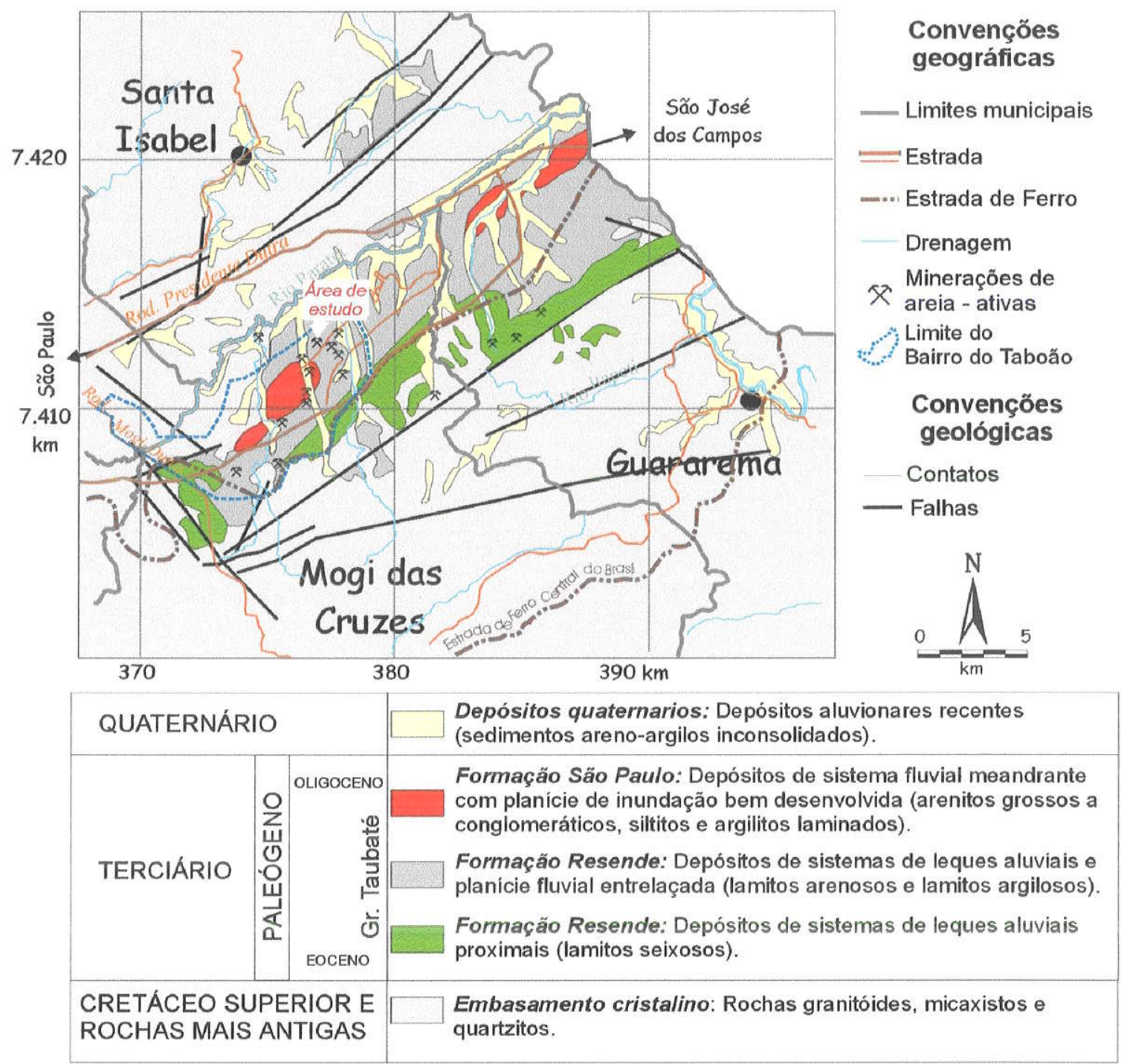

Figura 2.2: Mapa geológico da região de Mogi das Cruzes (adaptado de Sant’Anna, 1999)

\section{GEOLOGIA LOCAL}

No Bairro do Taboão, localizado na porção oeste da Bacia de Taubaté, ocorrem sedimentos dos fácies distal e mediano da associação de fácies da Formação Resende (litofácies R2 de Riccomini et al., 1991b). Subordinadamente afloram sedimentos da Formação São Paulo.

A Formação São Paulo ocorre isoladamente, com exposições, principalmente em frentes de lavra de minerações, reconhecida pelo predomínio de níveis arenosos. A Formação Resende é identificada pela expressiva ocorrência de níveis lamíticos esverdeados intercalados aos pacotes arenosos. 
Os afloramentos da Formação Resende são observados em frentes de lavra de minerações de areia e cortes de estrada, onde se observam as intercalações métricas de lamitos arenosos/argilosos, siltitos arenosos, arenitos, arenitos conglomeráticos e por vezes diamictitos. Os arenitos são caracterizados por gradação normal ou inversa, com estratificação cruzada de médio a pequeno porte, clastos do embasamento e de lamitos, de dimensões milimétricas a centimétricas.

Os lamitos são essencialmente constituidos por argilominerais, quartzo e feldspato (quase sempre caulinizado). A coloração esverdeada é característica dos níveis lamíticos não alterados, quando mais intemperizados os mesmos apresentam cores variegadas a arroxeadas. Localmente ocorrem lamitos arenosos e siltitos arenosos, que possuem maior quantidade de areia em sua composição. 


\section{CAPÍTULO III - MINERAÇÕES DE AREIA DE MOGI DAS CRUZES (SP)}

O município de Mogi das Cruzes situa-se na porção leste da Região Metropolitana de São Paulo - RMSP, sendo limitada pelos municípios de Arujá, Bertioga, Biritiba Mirim, Guararema, Itaquaquecetuba, Santa Isabel, Santo André e Suzano.

Durante muitas décadas a economia de Mogi das Cruzes esteve atrelada à agricultura (hortaliças e flores), introduzida há cerca de 100 anos pelos espanhóis e italianos foi prosseguida pelos imigrantes japoneses. Atualmente, a produção agrícola municipal abastece $35 \%$ do mercado do Estado de São Paulo, o que resulta em $14 \%$ da arrecadação municipal. A mineração é outra importante atividade econômica do município, responsável por $20 \%$ da economia (Prefeitura Municipal de Mogi das Cruzes, 2002), sendo caracterizada pela extração de bens minerais industriais (areia, argilas comuns, caulim, etc.), principalmente para a construção civil.

\section{A PRODUÇÃO DE AREIA DA REGIÃO DE MOGI DAS CRUZES}

A mineração em Mogi das Cruzes é basicamente exercida em dois pólos. Ao sul, nos Distritos de Jundiapeba e Biritiba-Ussú, são mineradas argilas comuns e plásticas, oriundas de depósitos quaternários das várzeas do Rio Tietê, e caulim proveniente de alteração de rochas pegmatiticas do embasamento. Ao norte, no Bairro do Taboão, encontram-se em operação 14 minerações de areia, todas situadas em depósitos sedimentares da Bacia de Taubaté.

Segundo estimativas de Cuchierato (2000), a demanda anual de areia para a Região Metropolitana de São Paulo (RMSP) é de 30 milhões de $\mathrm{m}^{3}$ (2,5 milhões de $\mathrm{m}^{3} / \mathrm{mês}$ ). Desse total, o distrito areieiro do Bairro do Taboão fornece mensalmente $170.000 \mathrm{~m}^{3}$ (Mineração Cessi - informação verbal, 2001).

Os dados da proporção de areia importada de outras regiões do Estado para abastecimento da RMSP variam de acordo com a fonte de informação.

Para Soares et al. (apud Zanchetta, 2000), 85\% do volume de areia consumido na RMSP provêm de outras regiões, enquanto Cuchierato (2000) apresenta valores de 50\%. Grande parte dessa divergência resulta da carência de dados oficiais do setor, sendo os valores de produção e consumo estimados a partir de fontes isoladas de informações. 
A demanda de areia da RMSP é suprida por diferentes fontes e distâncias, variando quanto à qualidade, preço e volume fornecido. Segundo dados da ANEPAC (2000), as minerações em aluviões ativos e inativos do Rio Paraíba do Sul (Jacareí, São José dos Campos, Caçapava, Taubaté, Tremembé e Pindamonhangaba) destinavam $600.000 \mathrm{~m}^{3} / \mathrm{mês}$ de sua produção para a comercialização na RMSP.

Até o ano de 1996, cerca de 3,7\% da areia consumida na RMSP eram importados do Vale do Ribeira - sul do estado (Bauermeister, 1996). O restante era transportado das regiões de Bofete, com areias extraídas das Formações Pirambóia (Bauermeister, 1996) e Botucatu (Bauermeister, 1996; Zanchetta, 2000), ambas da Bacia do Paraná, sendo que uma pequena parcela $(<1 \%)$ provém da região Sudoeste do Estado de Minas Gerais (Bauermeister, 1996).

Segundo Bauermeister (1996), os custos de produção de areia derivam do método de lavra empregado. Em 1996, o custo de extração por dragagem em leitos de rio era de US\$1,5$2,5 / \mathrm{m}^{3}$, enquanto que a operação em cava seca custava ao empreendedor US $\$ 6,5-8,8 / \mathrm{m}^{3}$.

A lavra em cava seca requer uma série de operações que incluem decapeamento para remoção de cobertura de solo e material estéril, desmonte hidráulico, bombeamento de polpas, peneiramento, lavagem e relavagem da areia para remoção de finos, e classificação granulométrica. Por outro lado, a operação em cava submersa é realizada por dragagem de sedimentos ativos e classificação em silos.

Os elevados custos de produção praticados pelas minerações do Bairro do Taboão, que lavram em cava seca, são compensados pela curta distância de transporte até o mercado consumidor da RMSP. Enquanto que as areias extraídas nos Vales do Paraíba e Ribeira percorrem mais de 100 e $180 \mathrm{~km}$, respectivamente, a areia do Distrito do Taboão é transportada por menos de $60 \mathrm{~km}$, pelas rodovias Presidente Dutra (BR 116) e Ayrton Senna (SP 70), ambas em bom estado de conservação e com um pedágio para nesse trecho. Para o abastecimento da região do ABC (Santo André, São Bernardo, São Caetano, Mauá, etc.) o escoamento é também realizado por estradas secundárias, passando pelo município de Suzano. Atualmente, os valores praticados não são oficialmente divulgados, sabe-se apenas que as areias do Vale do Paraíba e do Bairro do Taboão chegam ao consumidor com preços muito semelhantes.

Há uma tendência de aumento no número de minerações de areia para os próximos anos. Essa expectativa baseia-se na quantidade de novos requerimentos de pesquisa junto ao DNPM, órgão público federal responsável pelo controle e fiscalização do exercício das atividades de mineração em todo o Território Nacional. 
Segundo o Código de Mineração Brasileiro (DNPM, DECRETO-LEI N. ${ }^{\circ}$ 227, DE 27 FEVEREIRO DE 1967), a exploração de uma jazida depende do cumprimento de uma série de exigências e etapas junto ao DNPM (Departamento Nacional de Produção Mineral), CETESB (Companhia de Tecnologia de Saneamento Ambiental), Secretaria do Meio Ambiente e prefeituras municipais, finalizadas pela publicação da Concessão de Lavra ou Registro de Licenciamento no Diário Oficial da União (D.O.U.). Há ainda a exploração provisória em fases intermediárias do processo, através da Guia de Utilização, que é válida por 6 meses e tem a função de permitir a realização de uma lavra experimental para geração de receita durante o desenvolvimento da pesquisa mineral e a implantação da mina, além da avaliação tecnológica da substância.

Atualmente existem 103 processos registrados no Departamento Nacional de Produção Mineral (DNPM) para a exploração de areia nos municipios de Mogi das Cruzes e Guararema, dos quais 27 empreendimentos cumpriram as exigências legais necessárias para a operação, e outros 46 processos encontram-se em fase de pesquisa mineral, na qual serão definidas as viabilidades técnica e econômica das ocorrências minerais (Tabela 3.1).

Tabela 3.1: Situação legal dos processos para a substância areia nos municípios de Mogi das Cruzes e Guararema (DNPM-SICOM, 29 de abril de 2002).

\begin{tabular}{|c|c|c|c|c|}
\hline Fase do Processo & Mogi das Cruzes & Guararema & Total & Lavra \\
\hline Requerimento de Pesquisa & 14 & 6 & $\mathbf{2 0}$ & Não autorizada \\
\hline Autorização de Pesquisa & 38 & 8 & $\mathbf{4 6}$ & Autorizada mediante \\
Gequerimento de Lavra & 6 & 2 & $\mathbf{8}$ & Guia de Utilização \\
\hline Concessão de Lavra & 14 & 3 & $\mathbf{1 7}$ & \multirow{2}{*}{ Autorizada } \\
\hline Licenciamento & 10 & 0 & $\mathbf{1 0}$ & \\
\hline Total & $\mathbf{8 2}$ & $\mathbf{2 1}$ & $\mathbf{1 0 3}$ & \\
\hline
\end{tabular}




\section{CARACTERIZAÇÃO DO PROBLEMA}

A região de estudo situa-se na Bacia de Taubaté, onde predominam os depósitos sedimentares terciários da Formação Resende e, subordinadamente, corpos isolados da Formação São Paulo. Nesse contexto encontram-se 14 minerações de areia que compõem o distrito areieiro do Bairro do Taboão em Mogi das Cruzes, mais 3 empresas situadas na continuidade da mesma bacia, porém no município de Guararema (Figura 3.1 e Tabela 3.2).

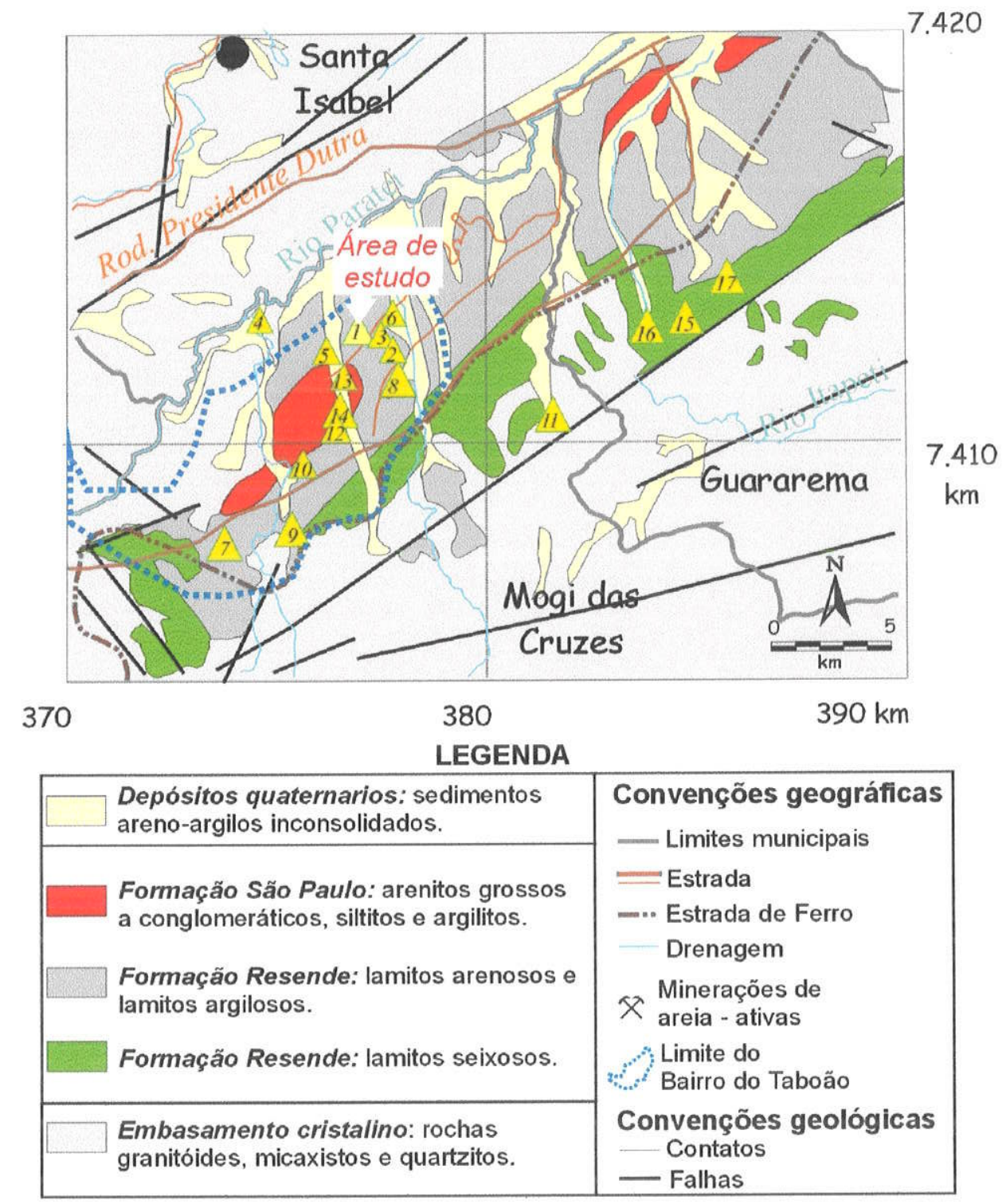

Figura 3.1: Mapa geológico da região do Bairro do Taboão em Mogi das Cruzes e Guararema (adaptado de Sant'Anna, 1999). 
Tabela 3.2: Principais minerações de areia da região de Guararema/Mogi das Cruzes

\begin{tabular}{|c|c|c|c|c|}
\hline $\mathbf{n}^{\circ}$ & Empresa & Contexto Geológico & Região & Município \\
\hline 1 & Cessi Comércio de Materiais para Const. Ltda. ${ }^{(2)}$ & \multirow{11}{*}{$\begin{array}{l}\text { Bacia de Taubaté } \\
\text { Fm. Resende }\end{array}$} & \multirow{14}{*}{ Bairro do Taboão } & \multirow{14}{*}{ Mogi das Cruzes } \\
\hline 2 & Empresa de Mineração JBS Ltda. ${ }^{(2)}$ & & & \\
\hline 3 & Empresa de Mineração JBS Ltda. ${ }^{(2)}$ & & & \\
\hline 4 & Extração de Areia e Pedra Cachoeira Ltda. (1) & & & \\
\hline 5 & Extração de Areia Taboão Ltda. ${ }^{\text {(1) }}$ & & & \\
\hline 6 & Itaquareia Ind. Ext. de Minérios Ltda. ${ }^{(1)}$ & & & \\
\hline 7 & Itaquareia Ind. Ext. de Minérios Ltda. ${ }^{(2)}$ & & & \\
\hline 8 & Mineração Raul Lerário ${ }^{(2)}$ & & & \\
\hline 9 & Porto de Areia e Ped. Saibro Luso Ltda. ${ }^{(2)}$ & & & \\
\hline 10 & Porto e Extração de Areia Três Coroas Ltda. ${ }^{(2)}$ & & & \\
\hline 11 & Real Empresa Ext. de Areia Ltda. ${ }^{(1)}$ & & & \\
\hline 12 & Dutra Extração de Areia Ltda. ${ }^{(2)}$ & \multirow{3}{*}{$\begin{array}{c}\text { Bacia de Taubaté } \\
\text { Fm. São Paulo }\end{array}$} & & \\
\hline 13 & Empresa Mineradora Boa Sorte Ltda. ${ }^{(1)}$ & & & \\
\hline 14 & Justo Extração de Areia Ltda. ${ }^{(2)}$ & & & \\
\hline & Produção mensal do Bairro do Taboão & & & $170.000 \mathrm{~m}^{3(3)}$ \\
\hline 15 & Proviga Ind. Min. Ltda (Extral) ${ }^{(1)}$ & \multirow{3}{*}{$\begin{array}{l}\text { Bacia de Taubaté } \\
\text { Formação Resende }\end{array}$} & \multirow{3}{*}{ Guararema } & \multirow{3}{*}{ Guararema } \\
\hline 16 & Proviga Ind. Min. Ltda (Fontoura) ${ }^{(3)}$ & & & \\
\hline 17 & Proviga Ind. Min. Ltda (Jomafe) ${ }^{(7)}$ & & & \\
\hline
\end{tabular}

Fontes: (1) Levantamento Cuchieratto (2000); ${ }^{(2)}$ Levantamento no Projeto; ${ }^{(3)}$ Informação verbal Cessi Comércio de Materiais para Construção Ltda. (2001). 
As ocorrências da Formação São Paulo no Bairro do Taboão são restritas, e observadas em apenas 3 minerações. Devido ao predomínio de sedimentos arenosos na Formação São Paulo, os rendimentos e recuperações no processo de extração e beneficiamento de areia são melhores que os encontrados em lavras de sedimentos da Formação Resende, composta por intercalações de arenitos e lamitos. Dessa forma, o estudo foi direcionado à problemática associada aos empreendimentos instalados sobre a Formação Resende.

A intercalação de corpos tabulares arenosos e lamíticos torna a lavra por desmonte hidráulico custosa e difícil, pois os níveis estéreis representam de 30 a $40 \%$ (em volume) dos recursos minerais. A remoção seletiva dos lamíticos (estéril) ocorre apenas nas porções superficiais (capeamento). Os demais níveis são lavrados juntamente com os pacotes arenosos e posteriormente separados manualmente ou com máquinas (rejeito), sendo depositados em bota-foras ou utilizados na manutenção de barragens de rejeitos. Em algumas situações, o avanço em profundidade é interrompido quando se atinge um pacote lamítico espesso, superior a $6 \mathrm{~m}$.

A destinação do rejeito/estéril associam-se dois problemas. O primeiro refere-se a limitação da área máxima para a exploração de areia, fixada pela legislação mineral em 50 ha (DNPM, Portaria n. ${ }^{\circ} 40$, de 10 de fevereiro de 2000), e a ocupação de parte do terreno por bota-foras tem como conseqüência direta na redução da vida útil da jazida. O segundo problema, refere-se às agressões ambientais causadas pela exposição às intempéries de materiais inconsolidados, provocando assoreamento de cursos d'água, além do impacto visual.

Embora existam essas dificuldades operacionais de lavra, os recursos minerais do distrito areieiro do Bairro do Taboão são substanciais e promissores para o abastecimento futuro da RMSP. Esse fato decorre pela disponibilidade em áreas pouco urbanizadas e pela proximidade com os mercados consumidores.

Valverde et al. (1997), fundamentados em parâmetros técnicos, como a espessura dos níveis arenosos, a granulometria, relação estéril/minério e cobertura associada, classificaram a potencialidade da região para produção de areia, como média a alta (Tabela 3.3). 
Tabela 3.3: Potencialidade das sub-áreas relativas ao Bairro do Taboão em Mogi das Cruzes e Norte de Guararema (Valverde et al., 1997).

\begin{tabular}{|c|c|c|c|c|c|c|}
\hline $\begin{array}{c}\mathrm{N}^{\circ} \text { da } \\
\text { Subárea }\end{array}$ & $\begin{array}{l}\text { Reserva } \\
\left(10^{6} \mathrm{~m}^{3}\right)\end{array}$ & $\begin{array}{l}\text { Espessura média } \\
(\mathrm{m})\end{array}$ & $\begin{array}{c}\text { Profundidade } \\
\text { máxima de cava }(\mathrm{m})\end{array}$ & $\begin{array}{c}\text { Razão } \\
\text { minériolestéril }\end{array}$ & $\begin{array}{c}\text { Cobertura } \\
(\mathrm{m})\end{array}$ & Classificação \\
\hline 27 & 62,2 & 17 & $>30$ & $2 a 4$ & $<3$ & alta \\
\hline 28 & 40,9 & 16 & $>30$ & 1 a 4 & $<3$ & alta \\
\hline 29 & 48,7 & 9,5 & 10 a 20 & 0,5 a 2 & $1 a 6$ & média \\
\hline 30 & 121 & 11,5 & 20 a 30 & 0,4 a 4 & 1 a 6 & média \\
\hline 31 & 122 & 10,9 & 10 a 20 & 0 a 4 & 1 a 6 & média \\
\hline 32 & 84 & 22,4 & $20 a>30$ & $0 a>4$ & 1 a 6 & alta \\
\hline 33 & 123,4 & 15,2 & 20 a 30 & $0 a>4$ & 1 a 18 & alta \\
\hline 34 & 227,9 & 18,8 & 20 a 30 & $0 a>4$ & 1 a 18 & alta \\
\hline 35 & 6,6 & 3,2 & 10 a 20 & 0 a 1 & 1 a 6 & baixa \\
\hline
\end{tabular}

As empresas situadas em Guararema, segundo essa classificação estariam inseridas em áreas de baixo potencial, cuja característica seria as pequenas espessuras e reservas.

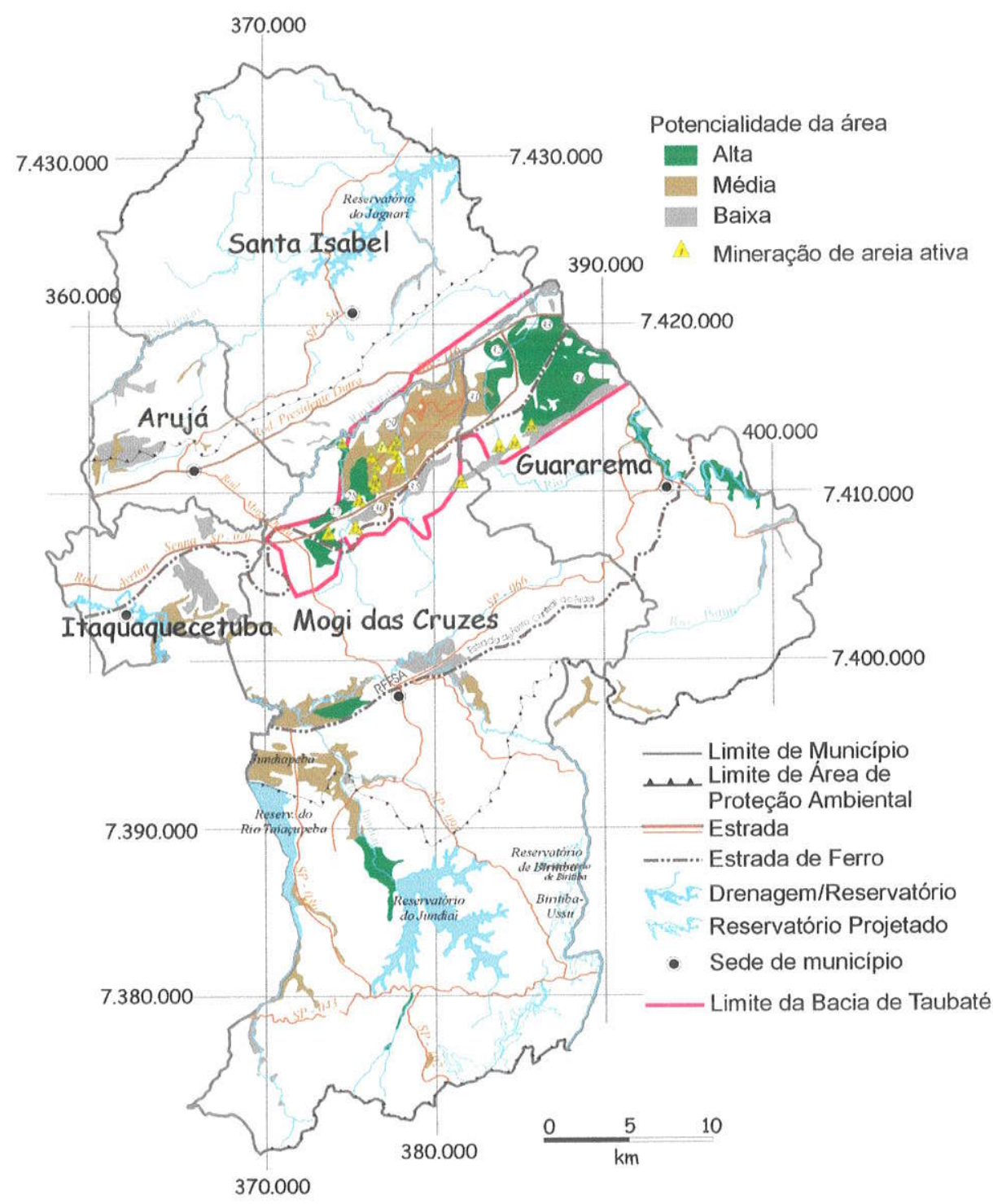

Figura 3.2: Mapa de potencialidade de areia (adaptado de Valverde et al., 1997) 
Segundo DNPM (2001), a reserva medida de areia e cascalho (substâncias agrupadas na estatística DNPM) do municipio de Mogi das Cruzes iguala-se à de Bofete ( 42,5 milhões de $\mathrm{m}^{3}$ ), porém são ainda inferiores às reservas de areia de Jacareí, no Vale do Paraíba $\left(\sim 107\right.$ milhões de $\left.\mathrm{m}^{3}\right)$. Esses dados enfatizam a média a alta potencialidade definida para a região de Mogi das Cruzes por Valverde et. al. (1997).

\subsection{Estudo de caso: Mineração Cessi, Mogi das Cruzes (SP)}

O estudo de caso foi desenvolvido junto a uma Mineração - Cessi Comércio de Materiais para Construção Ltda.-, cuja participação foi fundamental nas atividades de campo e cessão de dados de produção.

Localizada no Bairro do Taboão em Mogi das Cruzes, a Mineração Cessi possui tradição de mais de duas décadas na atividade de extração e comercialização de areia.

A extração de areia é realizada pelo método da cava seca, com desmonte hidráulico (jateamento de água sob pressão) nas bases das bancadas. O material empolpado (areia, finos e água) é bombeado por tubulações até o primeiro silo de classificação (Silo 1), onde passa por uma peneira estática para retenção de cascalhos e fragmentos de lamitos maiores que $19,0 \mathrm{~mm}(3 / 4)$. A seguir o material é novamente bombeado e peneirado (Silo 2), onde é retida a fração maior que $12,7 \mathrm{~mm}\left(1 / 2^{n}\right)$, igualmente constituída de lamitos e cascalhos. $O$ material passante é lavado em caixas de aço de $150 \mathrm{~m}^{3}$, onde é removida parte da fração mais fina (areia muito fina a argila), concentrando-se a fração areia por decantação.

Finalizando o processo, a polpa final é canalizada por gravidade para silos de $25-30 \mathrm{~m}^{3}$ para a classificação de areia grossa, média e fina (Silos 3), e remoção da lama sobrenadante, constituída de argila e silte.

Os resíduos grossos do processamento são depositados em bota-foras, e os finos em bacias de decantação, que na maioria das vezes são locadas em cavas desativadas (Figura 3.3 e Prancha 3.1). 


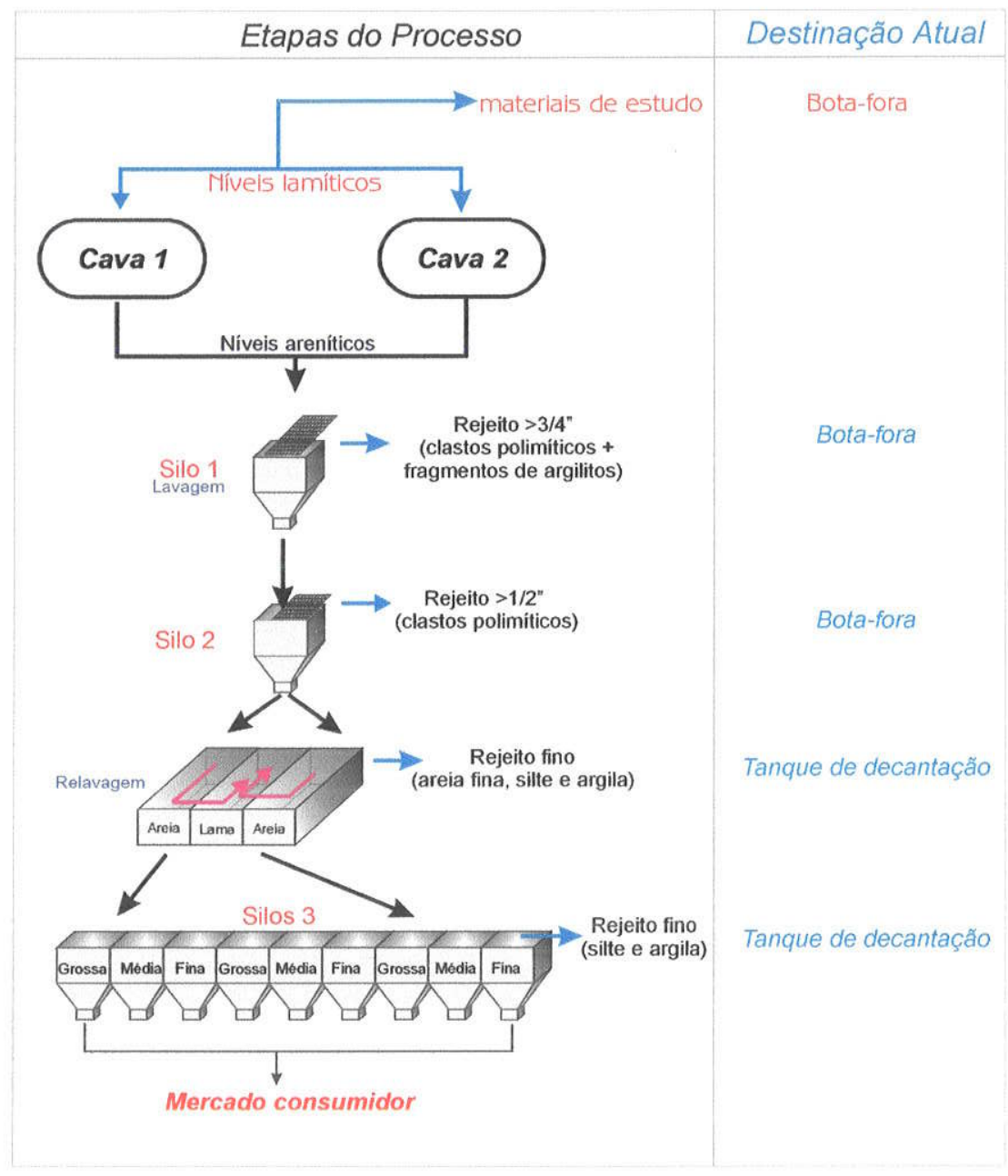

Figura 3.3: Fluxograma de beneficiamento de areia na empresa Mineração Cessi, com os produtos, resíduos e as respectivas destinações.

O volume de minério e os produtos extraídos variam de acordo com as frentes lavradas e as necessidades do mercado. Em média, segundo informações fornecidas verbalmente pela Mineração Cessi, são produzidos diariamente $650 \mathrm{~m}^{3}$ de areia (13 - $15 \mathrm{mil} \mathrm{m}^{3} / \mathrm{mês}$ ), além de grande quantidade de resíduos, como indicado na Tabela 3.4 .

Tabela 3.4: Dados de produção da empresa Cessi Materiais para Construção Ltda., em março de 2001.

\begin{tabular}{|c|c|c|c|}
\hline Material & $\begin{array}{c}\text { Volume } \\
\left.\text { ( } \mathbf{m}^{3} / \mathrm{dia}\right)\end{array}$ & $\begin{array}{c}\text { Produção } \\
\text { (\% em volume) }\end{array}$ & Destinação \\
\hline areia (fina a grossa) & 650 & 41,4 & Venda a varejo \\
\hline $\begin{array}{c}\text { rejeito + 3/4" (clastos polimíticos e } \\
\text { fragmentos de lamitos) }\end{array}$ & 50 & 3,2 & Bota fora \\
\hline $\begin{array}{c}\text { rejeito +1/2" (clastos polimíticos e } \\
\text { fragmentos de lamitos) }\end{array}$ & 20 & 1,2 & Bota fora \\
\hline lamitos & 600 & 38,2 & $\begin{array}{c}\text { Bota fora e manutenção } \\
\text { de barragem de rejeitos }\end{array}$ \\
\hline finos (areia muito fina a argila) & 250 & 15,9 & Tanque de decantação \\
\hline Total & 1570 & 100 & \\
\hline
\end{tabular}



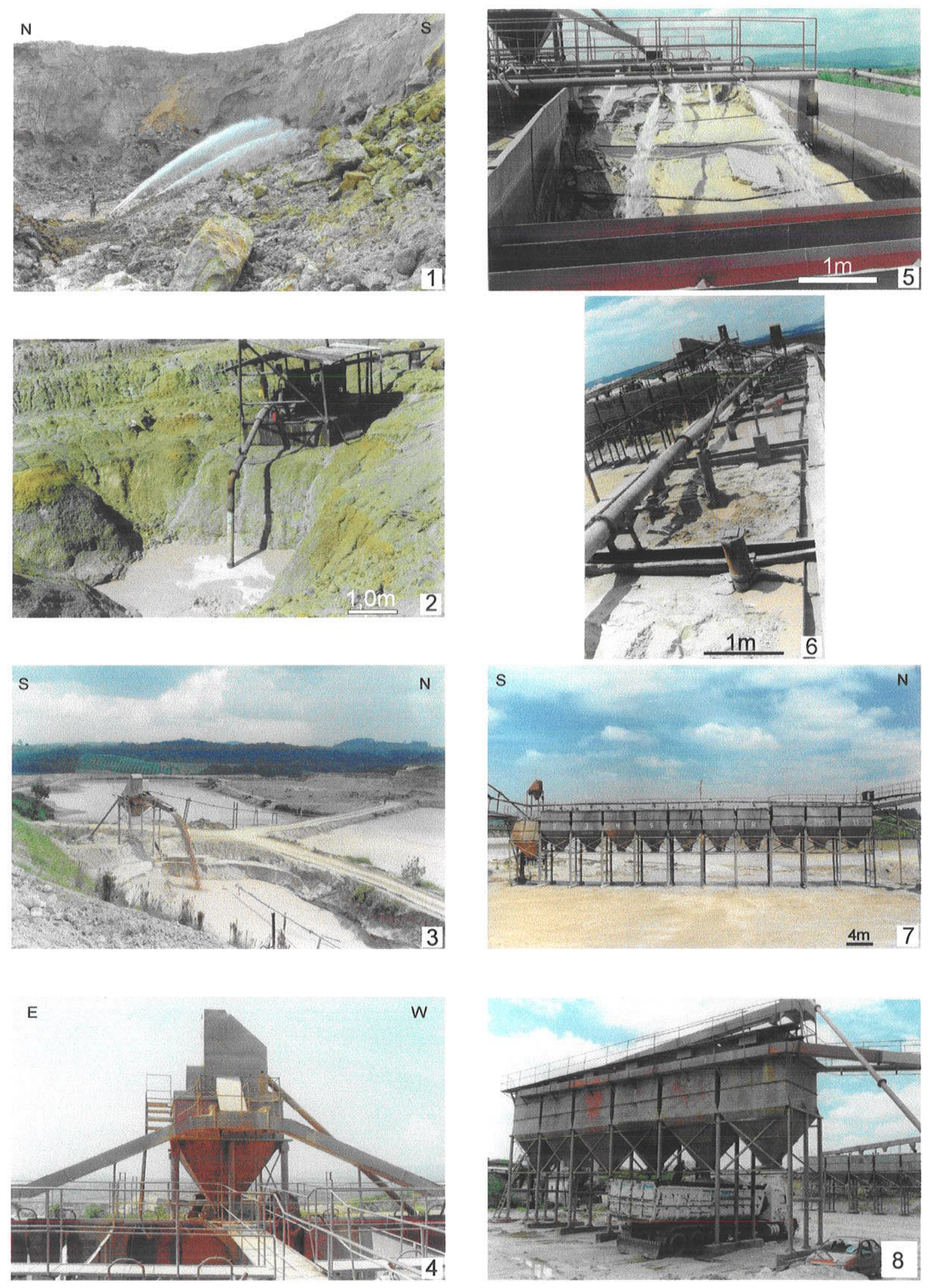

Prancha 3.1: Etapas do processo de extração e beneficiamento de areia: (1) Desmonte hidráulico; (2) Draga de bombeamento de polpa arenosa; (3) Peneira estática $(19,0 \mathrm{~mm})$ lavagem da areia e bombeamento para relavagem; (4)Peneira estática $(12,7 \mathrm{~mm})$; (5) Relavagem da areia; (6) Classificação de areia em três faixas granulométricas (grosso, médio e fino); (7) Vista frontal das caixas de classificação; (8) Expedição dos produtos finais. 
$\mathrm{Na}$ época de desenvolvimento do projeto a Mineração Cessi operava em duas frentes de lavra, definidas como Cavas 1 e 2, cujas características são descritas na seqüência.

Cava 1 - Aproximadamente $200 \mathrm{~m}$ de largura (direção NS) por 250m de comprimento (direção $\mathrm{EW}$ ) por $40 \mathrm{~m}$ de profundidade. O avanço da lavra é efetuado em uma única frente com talude de $50-60^{\circ}$, que pode localmente atingir $90^{\circ}$ gerando uma configuração de cava bastante instável. Devido à profundidade da operação são explorados níveis arenosos menos intemperizados, resultando em produtos de coloração amarelada a levemente rosadas.

O capeamento da Cava 1 é constituído por níveis lamíticos de espessura decimétrica à métrica intercalados por níveis decimétricos de arenitos (Figura 3.4). O decapeamento é realizado com retro-escavadeiras ou tratores de esteira, com a separação dos níveis lamíticos e dos arenosos.

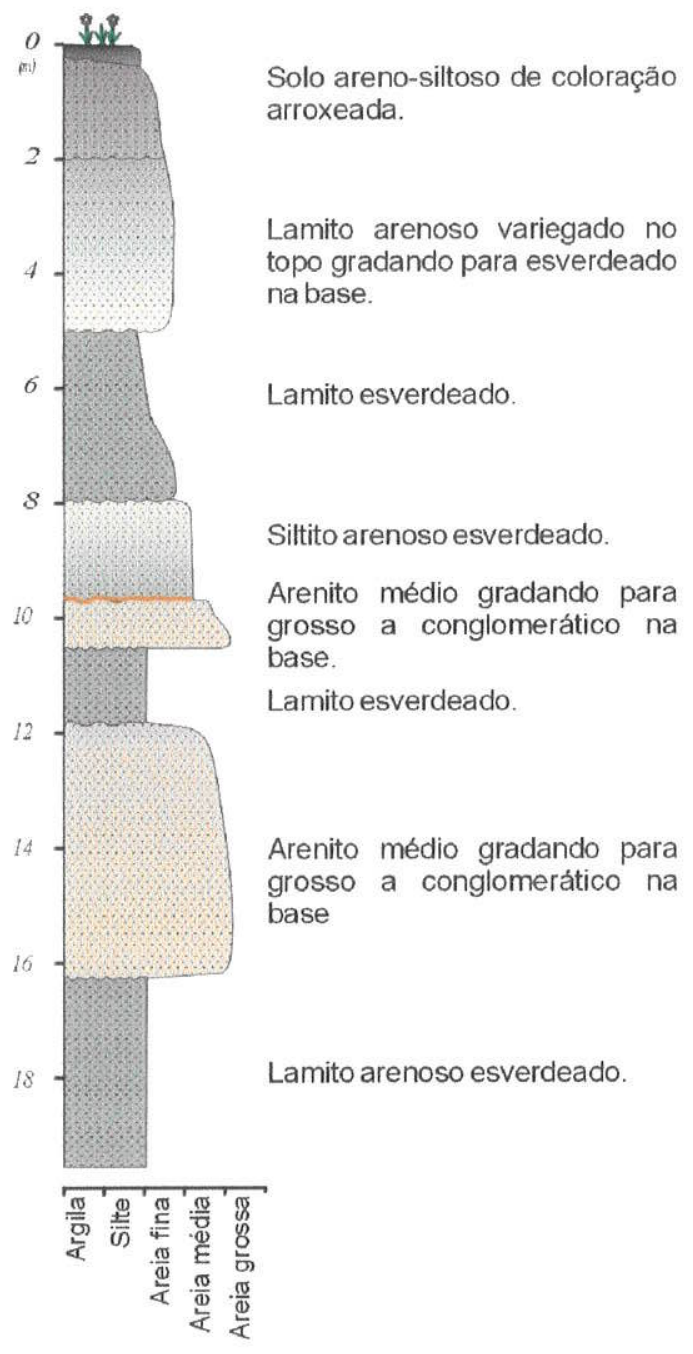

Figura 3.4: Capeamento da Cava 1 mostrando as intercalações de litotipos da Formação Resende, na Mineração Cessi. 
Cava 2 - A Cava 2 possui dimensões menores que a Cava 1, apresentando cerca de 90 $\mathrm{m}$ de largura por $180 \mathrm{~m}$ de comprimento e $20 \mathrm{~m}$ de profundidade. Pela pequena profundidade da cava, a frente de lavra é caracterizada por níveis de lamitos e arenitos mais intemperizados, resultado em produtos arenosos de coloração predominantemente rosados a arroxeados. $O$ decapeamento da Cava 2 consiste na remoção de $2-3 m$ de solo orgânico.

Nas bases das duas cavas encontram-se camadas de lamito de $12 \mathrm{~m}$ e $6 \mathrm{~m}$ de espessura, respectivamente. Esse fato tem inviabilizado economicamente o avanço em profundidade (Prancha 3.2).

Durante a primeira lavagem (Silo 1) as areias das duas cavas são homogeneizadas, uniformizando a coloração das duas fontes.

São reconhecidos, tanto na Cava 1 como na Cava 2, os niveis lamíticos esverdeados e arroxeados, de espessuras de 1 a $6 \mathrm{~m}$, intercalados aos pacotes métricos de arenito médio a grosso, de coloração amarelada a avermelhada, com estratificação cruzada acanalada de médio a pequeno porte.

A Figura 3.4 mostra as formas de contato normalmente observadas entre os litotipos em campo. Geraimente o contato basal dos níveis arenosos para os níveis lamíticos é erosivo, como ocorre a $16 \mathrm{~m}$ de profundidade. Para o topo observa-se a gradação para sedimentos mais finos (lamitos), como visto entre 5 e 9,8 m. Às vezes observam-se os niveis lamíticos truncando o topo de camadas arenosas, como mostrado em 12,2 m de profundidade.

Os niveis de lamitos frescos são facilmente distinguíveis dos demais litotipos através da coloração esverdeada, às vezes com brilho oleoso, estrutura maciça, geralmente com estrias de escorregamento. Há freqüente ocorrência de clastos angulosos de quartzo e feldspato caulinizado imersos na matriz argilosa. Quando em avançados estágios de alteração supérgena os lamitos apresentam coloração variegada a arroxeada. Numa situação intermediária, observa-se o lamito esverdeado gradando para arroxeado rumo aos contatos basal e de topo, localmente com manchas alaranjadas de percolação e precipitação de óxido de ferro.

Em alguns casos, nota-se a gradação lateral dos níveis lamíticos para lamitos arenosos ou mesmo para siltitos. A diferença é reconhecida pela mudança na textura da rocha, menos coesa e pouco brilhosa nos siltitos. 

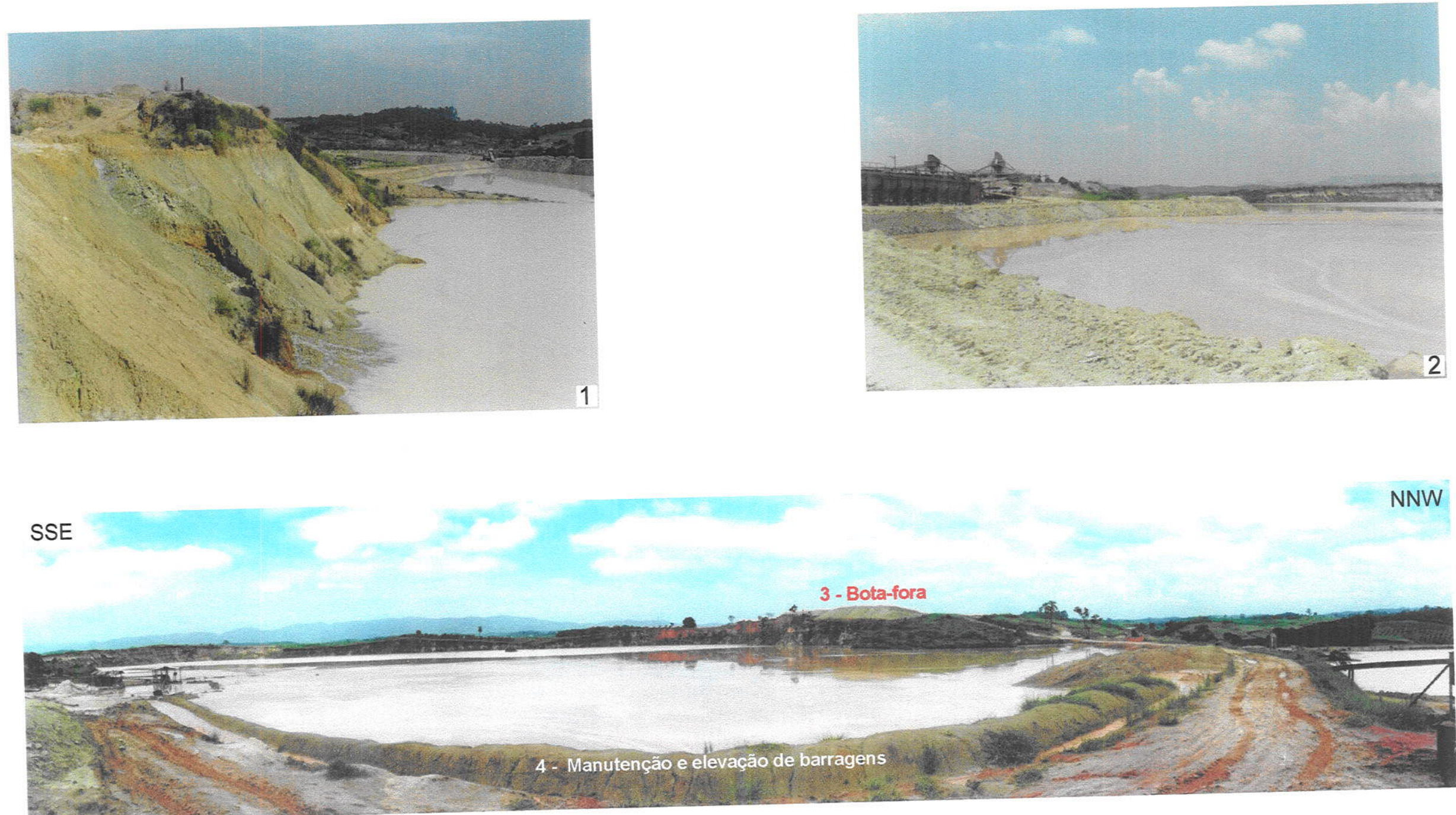

Prancha 3.2. Formas de ocorrência dos lamitos e utilização atual dos lamitos na Mineração Cessi: (1) Nível de lamito na base da Cava 2; (2) Material

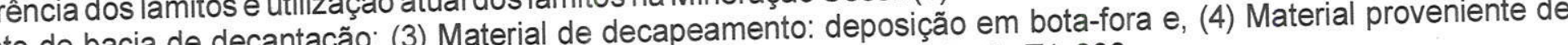
de decapeamento: alteamento de bacia de decantação, (3) 


\section{CAPÍTULO IV - ARGILAS E SEUS USOS INDUSTRIAIS}

\section{ARGILAS}

Neste trabalho buscou-se abranger os aspectos considerados essenciais para o entendimento das transformações térmicas e químicas que ocorrem em argilas quando submetidas a processos industriais (cerâmica e pozolânica), especialmente de materiais esmectíticos.

\subsection{Definição}

Por inúmeras vezes o termo argila é confundido com os nomes dos argilominerais que podem compô-la. Do ponto de vista sedimentológico, argila corresponde à fração granulométrica inferior a $4 \mu \mathrm{m}$ (por vezes $<2 \mu \mathrm{m}$ ), que pode ou não ser composta por argilominerais. O termo também se refere a "rocha" argila, geralmente composta por vários minerais, incluindo os argilominerais. O caulim é um exemplo conhecido de "rocha" argilosa com predominância do argilomineral caulinita.

Os argilominerais são aluminossilicatos hidratados, da classe dos filossilicatos, caracterizados pela clivagem perfeita (001) e hábito placóide. A estrutura atômica desses minerais é composta por alternância de duas unidades modulares planares, uma de tetraedros de silício, onde um átomo de Si é coordenado por 4 átomos de O; e outra de octaedros de alumínio, na qual um átomo $\mathrm{Al}$ ou $\mathrm{Mg}$ é coordenado por 6 átomos de $\mathrm{O} / \mathrm{OH}$, que resulta na unidade ou folha também conhecida como gibbsita - $\mathrm{Al}(\mathrm{OH})_{3}$, ou brucita $\mathrm{Mg}(\mathrm{OH})_{2}$ (Moore \& Reynolds, 1997). Da mesma forma que os tetraedros, os octaedros são mantidos unidos entre si através de fortes ligações covalentes.

Segundo Velde (1992), as variedades ou espécies de argilominerais encontradas na natureza são formadas por substituições de cátions de cargas similares ou distintas em sítios tetraedrais ou octaedrais. Essas substituições determinam o nome do mineral ou grupo, assim como as propriedades físicas e também o limite de estabilidade dos argilominerais em função das características químicas e físicas do meio.

A forma de ocupação dos sítios octaédricos diferencia as estruturas dioctaedrais das trioctaedrais (Figura 4.1). Nos tipos dioctaédricos, a ocupação é realizada por cátions trivalentes, geralmente o $\mathrm{Al}^{+3}$ podendo em alguns casos ocorrer substituição por $\mathrm{Fe}^{+3}$. Assim, 
argilominerais como por exemplo illita/esmectita, que apresentam simultaneamente camadas 2:1 e 1:1, chamados de camadas mistas ou interestratificados.

\section{2 Classificação}

A nomenclatura e a classificação dos argilominerais foram objetos de muitas discussões, devido às diferenças de critérios historicamente adotados. Em 1963 foi criado um subcomitê, a partir da Association Internationale pour L'Etude des Argiles (A.I.P.E.A.), designado a estabelecer a nomenclatura e a classificação dos argilominerais (Grim, 1968). Como resultado, os argilominerais foram classificados em tipos 2:1, 2:1:1(clorita) ou 1:1, segundo o empacotamento das folhas tetraédricas e octaédricas; em grupos e subgrupos; além da determinação de espécies, em alguns casos.

Moore \& Reynolds (1997) apresentou uma versão atualizada da classificação, que obedece às mesmas divisões dos grupos e subgrupos, com a inclusão da clorita no tipo $2: 1$, incorporação da illita, e atualização dos valores de carga de camadas. Não foram incorporados os argilominerais de camadas mistas, pois os autores consideraram que os componentes formadores dessas fases eram encontrados na classificação básica, como indicado na Tabela 4.1.

Segundo Srodón et al. (2001), a classificação utilizada não contemplou os poli-tipos de argilominerais. Havendo, dessa forma, a necessidade de considerar as variações químicas na identificação e nomenclatura de variedades de argilominerais dentro de um grupo. 
Tabela 4.1: Classificação dos filossilicatos com ênfase em argilominerais ( $\mathrm{Tr}$ - trioctaédricos; $\mathrm{Di}$ dioctaédricos), segundo Moore \& Reynolds (1997).

\begin{tabular}{|c|c|c|c|}
\hline Tipo de camada & $\begin{array}{c}\text { Grupo } \\
(z-\text { carga })\end{array}$ & Subgrupo & Espécies \\
\hline \multirow[b]{2}{*}{ 1:1 } & \multirow{2}{*}{$\begin{array}{l}\text { Serpentina } \\
\text {-caulinita } \\
\mathrm{z} \sim 0\end{array}$} & Serpentina (Tr) & Crisotila, antigorita, lizardita, etc. \\
\hline & & Caulinita (Di) & caulinita, dickita, nacrita, halloysita \\
\hline \multirow{15}{*}{$2: 1$} & \multirow{2}{*}{$\begin{array}{c}\text { Talco-pirofillita } \\
z \sim 0\end{array}$} & Talco (Tr) & Talco \\
\hline & & Pirofillita (D & Pirofillita \\
\hline & \multirow{2}{*}{$\begin{array}{c}\text { Esmectita } \\
z \sim 0,2-0,6\end{array}$} & Esmectita (Tr) & \multirow{2}{*}{$\begin{array}{c}\text { Saponita, hectorita } \\
\text { Montmorillonita, beidellita, nontronita. }\end{array}$} \\
\hline & & Esmectita (Di) & \\
\hline & \multirow{2}{*}{$\begin{array}{l}\text { Vermiculita } \\
z \sim 0,6-0,9\end{array}$} & Vermiculita (Tr) & Vermiculita \\
\hline & & Vermiculita (Di) & Vermiculita \\
\hline & \multirow{2}{*}{$\begin{array}{c}\text { Illita } \\
0,6<z<0,9\end{array}$} & Illita $(\mathrm{Tr})$ & $?$ \\
\hline & & Illita (Di) & Illita, glauconita \\
\hline & \multirow{2}{*}{$\begin{array}{c}\text { Mica } \\
z \sim 1,0\end{array}$} & Mica (Tr) & Biotita, flogopita, lepidolita \\
\hline & & Mica (Di) & Muscovita, paragonita \\
\hline & $\begin{array}{c}\text { Mica friável } \\
z \sim 2,0\end{array}$ & Mica friável (Di) & Margarita \\
\hline & \multirow{4}{*}{$\begin{array}{c}\text { Clorita } \\
\text { (z variável) }\end{array}$} & Clorita (Tr, Tr) & Cloritas comuns \\
\hline & & Clorita (Di, Di) & Donbassita \\
\hline & & Clorita (Di, $\mathrm{Tr}$ ) & Sudoita, cookeita \\
\hline & & Clorita $(\mathrm{Tr}, \mathrm{Di})$ & exemplos desconhecidos \\
\hline $2: 1$ & $\begin{array}{c}\text { Sepiolita } \\
\text {-paligorsquita } \\
\text { (z variável) }\end{array}$ & & $\begin{array}{c}\text { Sepiolita } \\
\text { paligorsquita }\end{array}$ \\
\hline
\end{tabular}

\section{AS ARGILAS ESMECTÍTICAS DA BACIA DE TAUBATÉ (SP) - TRABALHOS ANTERIORES COM ÊNFASE NA APLICAÇÃO INDUSTRIAL}

Esse item trata especificamente das aplicações industriais de argilas esmectíticas, buscando as possibilidades de uso para os lamitos argilosos da Formação Resende, cuja composição mineralógica é dada pela mistura dos argilominerais esmectita, caulinita e illita, além de outros minerais como quartzo e feldspato.

Através de intensos e sistemáticos estudos realizados por Riccomini (1989), Riccomini et al. (1991b) e Sant'Anna (1999), grande parte das características morfológicas, mineralógicas e genéticas do fácies lamítico tornou-se conhecida.

Os estudos mais sistemáticos para as argilas da Bacia de Taubaté foram realizados por Brandt Neto et al. (1991), seguidos por Sant'Anna (1999), com vistas a determinações paleoambientais de deposição e gênese. Brandt Neto et al. (1991) reconheceram duas formas de ocorrência das esmectitas. Na primeira, os cristais de esmectita de origem detrítica ocorrem como finas placas encurvadas com bordos arqueados, constituindo a matriz não alterada de lamitos de fácies mais argilosos da Formação Resende. Na segunda, os cristais 
de esmectita diagenética ocorrem em menor proporção, associados à calcita, sem feições que possam sugerir retrabalhamento mecânico. Os mesmos autores também identificaram cristais de caulinita diagenéticas e detríticas, sendo a segunda, de baixa cristalinidade.

O primeiro trabalho com vistas à aplicação industrial das argilas do Vale do Paraíba (Bacia de Taubaté) data da década de 50, na qual Paiva Neto \& Nascimento (1956) caracterizaram amostras de argila verde-oliva da Formação Tremembé, coletadas na região de São José dos Campos. Com base em resultados de análises químicas e termodiferenciais, bem como determinação da capacidade de troca catiônica, os autores concluíram que se tratava de nontronita, espécie do grupo das esmectitas.

As argilas da Formação Tremembé foram ainda qualificadas como terras-fuller, com poder de clarificação natural, porém de baixo rendimento (Souza Santos, 1963). Zandonadi (1974) aponta a improbabilidade de outros usos descorantes para essas argilas, exceto na clarificação de óleos vegetais. Mais recentemente, Franchi et al. (apud Sant'Anna, 1999) caracterizaram as argilas esmectíticas da região de Pindamonhangaba, e destacaram o alto rendimento como descorantes após tratamento químico de ativação ácida.

Souza Santos \& Santini (1965), percorrendo cortes de estrada da Rodovia Presidente Dutra, nas proximidades de Guararema, descreveram a ocorrência de argilas verdes, depositadas sobre folhelhos betuminosos, que eram utilizadas como aglomerantes de areia de fundição e descorantes de óleos vegetais e minerais. Em Tremembé foram descritas argilas compostas por argilominerais de camada mista illita-montmorillonita e caulinita utilizadas para as mesmas finalidades (Paiva Neto et al., 1956; Visconti et al., apud Souza Santos \& Santini, 1965; Zandonadi, 1974).

Riccomini et al. (1994) atribuíram como fatores preponderantes na determinação do rendimento tecnológico das esmectitas a origem detrítica e a neoformação, sobreposta pela alteração de argilominerais no ambiente lacustre,. Os autores ressaltaram ainda o difícil controle de qualidade de produtos tecnológicos quando argilas de níveis intemperizados são misturadas às argilas frescas, por apresentarem esmectitas de cristalinidades variadas.

Barelli et al. (1994) caracterizaram três amostras de argilas compostas por montmorillonita, caulinita e mica, coletadas no Vale do Paraíba, com vistas ao estudo do fenômeno de desagregabilidade, parâmetro importante para aplicações em geotecnia. Os autores definiram que o esboroamento verificado nessas argilas é aparentemente causado por fenômenos de origem capilar, associado à presença de argilominerais esmectíticos que, quando molhados, causam pressão de expansão. 


\section{APLICAÇÃO DE ARGILAS}

As argilas e os argilominerais têm uma infinidade de aplicações nas indústrias alimenticias, de papel, petrolifera, cerâmica, cimento, farmacêutica, plásticos, engenharia, etc..

O uso num determinado segmento industrial depende das características físicas, químicas e mineralógicas, pois são muitas as variedades de argilominerais encontradas na natureza, constituindo na maioria das vezes, argilas poliminerálicas. Murray (1991; 2000) apresentou uma visão geral sobre as aplicações tradicionais para caulim e esmectita (Tabela 4.2).

Tabela 4.2: Aplicações industriais de algumas argilas (Murray, 1991; 2000)

\begin{tabular}{|l|c|c|}
\hline \multicolumn{2}{|c|}{ Indüstria } & \multicolumn{2}{c|}{ Argila } \\
\cline { 2 - 3 } & Caulim & Esmectita \\
\hline Abrasivos para polimento & & \\
\hline Adesivos & & \\
\hline Aglomerante de alimento animal & & \\
\hline Aglomerantes de minérios & & \\
\hline Aglomerantes para moldes de fundição & & \\
\hline Agricultura & & \\
\hline Carga para borracha & & \\
\hline Catalisadores & & \\
\hline Clarificação de vinhos e cervejas & & \\
\hline Clarificação de óleos mineral e vegetal & & \\
\hline Dessecantes & & \\
\hline Fabricação do cimento & & \\
\hline Fibra de vidro & & \\
\hline Fluido de perfuração & & \\
\hline Indústria cerâmica & & \\
\hline Indústria de fertilizantes & & \\
\hline Indústria de papel & & \\
\hline Indústria farmacêutica & & \\
\hline Inseticidas & & \\
\hline Refratários & & \\
\hline Sanitários para cães e gatos & & \\
\hline Tinta & & \\
\hline
\end{tabular}

Dentre as inúmeras aplicações para argilas esmectíticas, neste estudo foram enfatizados dois segmentos, o cerâmico (estrutural e revestimento) e cimento (como pozolana). Os fatores decisivos na escolha foram: o volume de material consumido e a mínima necessidade de beneficiamento. Em ambos os casos, as matérias-primas são comercializadas na forma bruta, sem necessidade de rebuscados processos de classificação granulométrica ou cominuição, o que é mais compativel com a pequena capacidade tecnológica das empresas de mineração de areia. 


\subsection{O Setor Cerâmico}

A história da cerâmica brasileira iniciou-se nos primórdios do século $X X$, com instalação das primeiras indústrias de louça doméstica, financiadas por capitais nacionais procedentes de lucros da atividade cafeeira paulista (Salles \& Azevedo, 1965).

Gross (1957) discorreu sobre a precariedade da indústria nacional no que se refere a produtos estruturais de argila e, também, sobre a carência de pesquisa. Segundo Garroni (1958), a concorrência mais intensa e a presença de mercados mais exigentes obrigaram as indústrias a tomarem um novo rumo, de caráter mais científico, menos empírico e artesanal. É interessante notar que a preocupação com a qualidade na indústria cerâmica tem pelo menos meio século de existência.

Hoje, a indústria cerâmica tem um papel importante na economia do pais, com participação de $1 \%$ do PIB (Produto Interno Bruto). O valor anual da produção, sem considerar os setores de vidro e cimento, é da ordem de US\$ 6 bilhões, dos quais US\$ 750 milhões referem-se à comercialização de matérias-primas naturais (Associação Brasileira de Cerâmica - ABC, 2002).

Segundo ABC (2002), o setor cerâmico é amplo e heterogêneo, sendo a sua segmentação decorrente de diversos fatores, como tipos de matérias-primas utilizadas, propriedades e uso final dos produtos (Tabela 4.3). 
Tabela 4.3: Panorama setorial dos principais segmentos cerâmicos.

\begin{tabular}{|c|c|c|c|c|c|}
\hline Segmento & $\begin{array}{l}\text { Produção } \\
\text { anual }\end{array}$ & $\begin{array}{c}\text { Consumo de } \\
\text { Matéria-prima } \\
\text { (t/ano) }\end{array}$ & $\begin{array}{c}\text { Tipos de matérias- } \\
\text { primas }^{(1)}\end{array}$ & $\begin{array}{c}\mathrm{N}^{0} \text { de } \\
\text { empresas }\end{array}$ & $\begin{array}{l}\text { Faturamento } \\
\text { (US\$) }\end{array}$ \\
\hline $\begin{array}{l}\text { Cerâmica } \\
\text { vermelha }\end{array}$ & $70.000 .000 t^{(5)}$ & $90.000 .000^{(6)}$ & argilas comuns & $11.000^{(5)}$ & 4,2 bilhões $^{(5)}$ \\
\hline Revestimento & $400.000 .000 \mathrm{~m}^{2}$ & $6.000 .000^{(1)}$ & $\begin{array}{c}\text { argilas comuns (40 a } 50 \%) \text {, } \\
\text { argilas plásticas (15 a } 20 \%) \text {, } \\
\text { fundentes feldspáticos e filito } \\
\text { (20 a } 25 \%) \text {, } \\
\text { outros fundentes - } \\
\text { carbonatos, talco }(5 \text { a } 10 \%)\end{array}$ & $127^{(3)}$ & 1,3 bilhões ${ }^{(1)}$ \\
\hline $\begin{array}{l}\text { Isoladores } \\
\text { elétricos de } \\
\text { porcelana }^{(5)}\end{array}$ & $33.000 t^{(1)}$ & & & $6^{(15}$ & 40 milhões ${ }^{(1)}$ \\
\hline $\begin{array}{l}\text { Fritas e } \\
\text { corantes }\end{array}$ & $230.000 t^{(1)}$ & & & $22^{(1)}$ & 140 milhões \\
\hline Louça de mesa & $\begin{array}{c}100.800 .000 \\
\text { peças }\end{array}$ & & & $6^{(1)}$ & 54 milhões \\
\hline $\begin{array}{l}\text { Cerâmica } \\
\text { artística }\end{array}$ & $\begin{array}{l}1.800 .000 \\
\text { canecas }^{(1)}\end{array}$ & & & $200^{(1)}$ & 14 milhöes ${ }^{(1)}$ \\
\hline Refratário & & $500.000^{(1)}$ & $\begin{array}{l}\text { quartzo, magnesita, argilas } \\
\text { refratárias, bauxita, zircão, } \\
\text { cromita, etc }\end{array}$ & $44^{(1)}$ & 380 milhões (1) \\
\hline Louça sanitária & & $180.000^{(3)}$ & $\begin{array}{l}\text { argila ball clay, caulim, } \\
\text { feldspatos, talco, filito }\end{array}$ & & 148 milhões (1) \\
\hline Cimento & $38.927 .123 \mathrm{t}^{(2)}$ & $50.000 .000^{(3)}$ & calcário, argila, gesso & & 8,4 bilhões $^{(4)}$ \\
\hline Vidro & $2.065 .000 \mathrm{t}^{(5)}$ & $2.170 .000^{(3)}$ & $\begin{array}{c}\text { areia quartzosa }(75 \%) \\
\text { barilha }(12 \%) \\
\text { calcário }(11 \%) \\
\text { feldspato }(2 \%)\end{array}$ & $39^{(3)}$ & 2,66 bilhões $^{(3)}$ \\
\hline $\begin{array}{l}\text { Cerâmica } \\
\text { técnica }\end{array}$ & & & & & 300 milhōes. ${ }^{(1)}$ \\
\hline Filtros de água & & & & & 23,7 milhões ${ }^{(1)}$ \\
\hline $\begin{array}{l}\text { Matérias- } \\
\text { primas }\end{array}$ & & & & & 750 milhões ${ }^{(1)}$ \\
\hline
\end{tabular}
(1) Bustamante \& Bressiani (2000).
(2) Sindicato Nacional das Indústrias de Cimento (2002).
(3) Associação Técnica Brasileira das Indústrias Automáticas de Vidro (2002).
(4) Considerando preço médio de $R \$ 90,0 / t$ (DNPM, 2001) e U $\$ 1=R \$ 2,40$.
(5) Associação Brasileira de Cerâmica (2002).
${ }^{(6)}$ Calculado segundo a perda de $30 \%$ durante o processamento cerâmico (dado empírico).

Dos segmentos existentes, os de cerâmica vermelha e de revestimento constituem a maior parcela da produção brasileira, seja pelo volume produzido ou seja pelo faturamento anual. Assim, ambos são responsáveis pelo maior consumo de matérias-primas argilosas do setor, fato que os tornam atrativos para investigação e potencialização da aplicação dos lamitos extraídos nas minerações de areia.

O segmento de cerâmica de revestimento vem mostrando crescimento anual contínuo de 6-7\% na produção de pisos e revestimentos (ANFACER, 2002), o que leva a crer que haverá necessidade futura de demanda de matérias-primas cerâmicas. 


\subsubsection{Cerâmica vermelha (estrutural)}

Pertencem ao segmento de cerâmica vermelha ou cerâmica estrutural, os materiais de coloração avermelhada após queima, utilizados em construção civil (tijolos, blocos, telha e tubos cerâmicos/manilhas) e também em agregados leves (argila expandida), utensílios domésticos e de adorno. As lajotas muitas vezes são enquadradas nesse grupo ou em cerâmicas de revestimento.

A produção anual do setor de cerâmica vermelha foi estimada em 70 milhões de toneladas em 2000, produzidas por 11.000 empresas ( $A B C, 2002)$, das quais cerca de 3.600 (1.600 cerâmicas e 2.000 olarias) concentram-se na região sudeste do país (SENAl apud Motta et al., 2001). Devido ao déficit habitacional do país, espera-se que haja um crescimento do segmento nos próximos anos (Motta et al., 2001).

\subsubsection{Argilas para cerâmica vermelha}

Embora as matérias-primas para cerâmica vermelha sejam abundantes, seu aproveitamento tem a limitação econômica da distância entre a jazida e a indústria (Tanno \& Motta, 2000). Para que a produção de peças cerâmicas vermelhas tenha custos e preços competitivos, a indústria deve estar muito próxima da jazida, para que haja o mínimo de gasto com transporte de matérias-primas.

As matérias-primas para cerâmica estrutural são processadas através de operações mais simplificadas que os demais segmentos cerâmicos, mas que requerem igual atenção frente à necessidade de qualidade do produto final. A partir da lavra, a matéria-prima (ou matérias-primas, dependendo da região) é submetida aos processos de desagregação, laminação, homogeneização, desaeração em câmaras à vácuo, conformação por extrusão para a produção de blocos, seguidas, se forem fabricadas telhas, de prensagem, secagem e queima em temperaturas inferiores à $1000^{\circ} \mathrm{C}$. O armazenamento de matérias-primas para sazonamento é prática comum nessas empresas.

Segundo Pracidelli \& Melchiades (1997), as argilas de granulação muito fina apresentam boa plasticidade, porém necessitam de quantidades elevadas de água para desenvolvê-la. Em função do alto grau de compactação, a porosidade existente é reduzida, dificultando a eliminação de água durante a secagem, o que provoca um aumento do gradiente da umidade e, consequentemente, fortes retrações diferenciais e deformações. O ciclo de secagem deve ser longo, com aquecimento lento para materiais que apresentam esse comportamento. Apesar dessas desvantagens, geralmente resultam em produtos de elevadas resistências mecânicas a seco e após a queima. 
Zandonadi (1982) pesquisou a utilização de bentonitas de Campina Grande (PB) em vários segmentos cerâmicos, com diferentes formulações. Para a cerâmica estrutural, a excessiva plasticidade deve ser controlada através da adição de minerais finos não plásticos, a fim de prevenir o surgimento de defeitos nas peças. A adição adequada de desplastificantes eficientes (granulometria maior que $60 \mu \mathrm{m}$, superior a silte) reduz o grau de compactação, permitindo a eliminação da água no sentido do interior à superfície da peça e, como conseqüência, a retração também é reduzida. Os desplastificantes mais comuns são areia $(50-500 \mu \mathrm{m})$, chamota $(80-800 \mu \mathrm{m})$ e pó de carvão (1 a $2 \%$, que participa somente da fase inicial de queima). No entanto, a adição desses materiais requer controle da quantidade de água, a fim de facilitar o processo de extrusão (Pracidelli \& Melchiades, 1997).

A partir da literatura, foi feita uma breve compilação dos dados de caracterização cerâmica para matérias-primas argilosas com composições esmectiticas (Tabela 4.4), a fim de se conhecer os possíveis comportamentos de materiais naturais.

Morgado (1993) caracterizou um conjunto de 29 argilas de diversas procedências geológicas do Estado de Santa Catarina, com a determinação de parâmetros físicos pósqueima à 950,1250 e $1450^{\circ} \mathrm{C}$, em corpos-de-prova prensados, visando a pré-qualificação para cerâmica estrutural e de revestimento. Os produtos obtidos para a temperatura de 950 ${ }^{\circ} \mathrm{C}$ apresentaram elevada absorção de água (>13\%) e resistências mecânicas inferiores a $13 \mathrm{MPa}$, valores satisfatórios para a fabricação de blocos estruturais.

Strazzera et al. (1997) caracterizaram argilas de três formações geológicas terciárias, oriundas da região de Sardenha (Itália), que são utilizadas como matéria-prima na fabricação de telhas, blocos, etc.. A amostra da Formação Samassi (SAM) apresentou alta retração de secagem devido à elevada quantidade de esmectita, além da excessiva porosidade após queima, possivelmente atribuida ao alto teor de carbonatos, restringindo o uso em misturas com outras matérias-primas para fabricação de blocos comuns. 
Tabela 4.4: Compilação bibliográfica de resultados cerâmicos para argilas de diferentes composições extrudadas.

\begin{tabular}{|c|c|c|c|c|c|}
\hline Autor & Amostra & $\begin{array}{c}\text { Composição Mineralógica } \\
\text { (\% em peso) }\end{array}$ & $\begin{array}{l}\text { Temperatura } \\
\text { de queima }\left({ }^{\circ} \mathrm{C}\right)\end{array}$ & $\begin{array}{l}\text { Resistência } \\
\text { Mecânica } \\
\text { (MPa) }\end{array}$ & $\begin{array}{l}\text { Absorção de } \\
\text { água } \\
\text { (\% ém peso) }\end{array}$ \\
\hline \multirow{3}{*}{$\begin{array}{l}\text { Strazzera } \\
\text { et. al. } \\
(1997)\end{array}$} & $\mathrm{ClX}$ & $\begin{array}{l}\text { illita (25-34), quartzo (25-36), caulinita } \\
\text { (tr-14), carbonatos (19-24), } \\
\text { clorita (tr-8), feldspato (tr-16), } \\
\text { interestratificado de illita/esmectita }\end{array}$ & $800-900$ & $9-19$ & $17-27$ \\
\hline & USS & $\begin{array}{c}\text { illita }(32-39) \text {, quartzo }(21-42) \\
\text { caulinita (tr-10), carbonatos }(3-20) \\
\text { clorita (tr-9), feldspato (tr-12) }\end{array}$ & $800-900$ & $11-14$ & $18-23$ \\
\hline & SAM & $\begin{array}{c}\text { illita (tr-20), esmectita (tr-29), } \\
\text { quartzo }(22-39) \text {, caulinita (tr-9), } \\
\text { carbonatos }(4-39) \text {, feldspato }(7-23 \%)\end{array}$ & $800-900$ & $7-11$ & $30-36$ \\
\hline \multirow{8}{*}{$\begin{array}{l}\text { Florêncio } \\
\text { (1999) }\end{array}$} & \multirow{4}{*}{$\begin{array}{l}\text { Ritmito } \\
\text { cinza }\end{array}$} & \multirow{4}{*}{$\begin{array}{l}\text { quartzo, caulinita, illita, esmectita, } \\
\text { clorita, interestratificados, feldspato }\end{array}$} & 850 & 21,5 & 13,5 \\
\hline & & & 925 & 33,3 & 11,5 \\
\hline & & & 1000 & 42,3 & 6,0 \\
\hline & & & 1075 & 49,2 & 0,2 \\
\hline & \multirow{4}{*}{ Argilito } & \multirow{4}{*}{$\begin{array}{l}\text { quartzo, caulinita, illita, esmectita (tr) } \\
\text { clorita, interestratificados, feldspato }\end{array}$} & 850 & 7,5 & 19,3 \\
\hline & & & 925 & 11,1 & 19,2 \\
\hline & & & 1000 & 13,3 & 18,2 \\
\hline & & & 1075 & 21,1 & 14,0 \\
\hline
\end{tabular}

tr - traço

Nota-se a heterogeneidade dos índices físicos obtidos. As argilas esmectíticas SAM e Ritmito Cinza resultaram em índices físicos distintos, possivelmente pela influência de impurezas minerais presentes (carbonatos, feldspatos, etc.). Essas diferenças evidenciam a necessidade insubstituivel de caracterização e realização de ensaios cerâmicos para a determinação das características de matérias-primas.

As especificações técnicas brasileiras para produtos cerâmicos estruturais variam de acordo com o tipo de aplicação. Para blocos para alvenaria (vedação e estrutural) são especificadas as resistências mecânicas à compressão para produtos finais (NBR 7171/83 - ABNT, 1983) (Tabela 4.5).

Tabela 4.5: Especificação técnica para blocos cerâmicos extrudados, segundo NBR 7171/83 (ABNT, 1983) e absorçâoo de água, segundo IPT (apud Florêncio, 1999).

\begin{tabular}{|c|c|c|c|}
\hline Tipo de bloco & Categoria & $\begin{array}{c}\text { Resistência à Compressão } \\
\text { (Mpa) }\end{array}$ & $\begin{array}{c}\text { Absorção de água } \\
\text { (\% em peso) }\end{array}$ \\
\hline \multirow{2}{*}{ Vedação } & $\mathrm{A}$ & 1,5 \\
\hline & $\mathrm{B}$ & 2,5 \\
\hline \multirow{2}{*}{ Estrutural } & $\mathrm{C}$ & 4,0 & \multirow{2}{*}{5 a $20 \%$} \\
& $\mathrm{D}$ & 7,0 \\
& $\mathrm{E}$ & 10,0 & \\
\hline
\end{tabular}


Em ensaios laboratoriais são determinadas as resistências mecânicas à flexão, pois não existem normas para ensaios de matérias-primas. Souza Santos (1989) apresentou valores-limite, determinados em laboratório, para a qualificação de massas cerâmicas para uso na fabricação de tijolos, blocos furados e telhas (Tabela 4.6).

Tabela 4.6: Valores recomendados para matérias-primas cerâmicas, obtidos em ensaios realizados em laboratório (Souza Santos, 1989)

\begin{tabular}{|c|c|c|c|c|}
\hline \multirow{2}{*}{$\begin{array}{c}\text { Produtos } \\
\text { cerâmicos }\end{array}$} & \multirow{2}{*}{\begin{tabular}{c} 
Conformação \\
\cline { 3 - 5 }
\end{tabular}} & $\begin{array}{c}\text { Resistência Mecânica à Flexão-minimo } \\
\text { a seco(MPa) }\end{array}$ & $\begin{array}{c}\text { Absorção de água } \\
\text { - máximo } \\
\text { quem em peso) }\end{array}$ \\
\hline tijolos de alvenaria & manual & 1,5 & 2,0 & - \\
\hline blocos furados & extrusão & 2,5 & 5,5 & 25 \\
\hline telhas & $\begin{array}{c}\text { extrusão } e \\
\text { prensagem }\end{array}$ & 3,0 & 6,5 & 20 \\
\hline
\end{tabular}

\subsubsection{Cerâmica de revestimento}

A cerâmica de revestimento compreende os materiais empregados na construção civil para revestir paredes (azulejos), pisos e bancadas.

No Brasil, é um dos segmentos mais importantes e mais desenvolvidos tecnologicamente, sendo representado por cerca de 121 indústrias. O país tem produzido anualmente cerca de 400 milhões de $\mathrm{m}^{2}$ de revestimentos cerâmicos (ANFACER, 2002), constituindo-se o $4^{\circ}$ produtor mundial, após a China, Itália e Espanha (ABC, 2000; Bustamante \& Bressiani, 2000).

Embora o Brasil seja um grande produtor de revestimentos, representa apenas $4,8 \%$ do mercado mundial, com a produção basicamente comercializada no continente americano. Isso mostra que o país tem o grande desafio de aumentar sua participação nas exportações, o que se apoia na produção de materiais tecnológica e economicamente mais competitivos (ABC, 2000).

Segundo ANFACER (2002), há expectativa de crescimento no consumo de revestimento cerâmico no Brasil. Essa avaliação baseou-se no baixo consumo per capita brasileiro de $2,2 \mathrm{~m}^{2} / \mathrm{hab}$., contra $3,1 \mathrm{~m}^{2} /$ hab. da Itália, 4,9 $\mathrm{m}^{2} / \mathrm{hab}$. de Portugal e, $5,5 \mathrm{~m}^{2} / \mathrm{hab}$. de Taiwan e Espanha.

A produção de revestimentos cerâmicos na última década foi marcada por um enorme crescimento mundial. No Brasil o incremento na produção foi de $138 \%$ (ANFACER apud Gambuli, 2001). A China, em 2000, teve um surpreendente aumento na produção que chegou a $700 \%$, produzindo cerca de 1600 milhões de $\mathrm{m}^{2} /$ ano (Gambuli, 2001), contra cerca de 400 milhões de $\mathrm{m}^{2} / a n o$ no Brasil (ANFACER, 2002). As indústrias operam atualmente 
com cerca de $88,1 \%$ da capacidade instalada, permitindo o aumento da produção por alguns anos (ABC, 2000, Bustamante \& Bressiani, 2000).

Até 1998, o pólo Cerâmico de Santa Gertrudes (SP) respondia por $62 \%$ da produção de revestimentos cerâmicos no Brasil (Bustamante, 1998; Motta et al., 1998), sendo $70 \%$ destinada ao mercado interno e 10\% à exportação (Mercosul, EUA e Europa) (Bustamante, 1998). Segundo ANFACER (2002), o mesmo pólo hoje representa $63 \%$ do total nacional.

A fabricação de revestimentos cerâmicos no Brasil é realizada por dois processos: a via úmida e a via seca, os quais apresentam características bastante distintas, sejam tecnológicas ou econômicas.

Em particular, a Região Metropolitana de São Paulo, com expressiva participação na produção de revestimentos cerâmicos (cerca de $5 \%$ do total nacional), é composta por 4 empresas que processam suas matérias-primas exclusivamente por via úmida.

Processo Via úmida - A via úmida, encontrada em quase todos os pólos cerâmicos brasileiros, produz suportes de cores mais claras, que são obtidos a partir de uma mistura de $70-80 \%$ de matérias-primas argilosas (argilas comuns, argilas plásticas) e 20-30\% de matériasprimas complementares (feldspatos, areias feldspáticas, quartzo, talco, carbonatos, etc.).

Para a obtenção da massa cerâmica no processo por via úmida, são necessárias moagem e homogeneização das matérias-primas em meio aquoso, seguidas de secagem e atomização evaporação parcial da água contida na barbotina (suspensão aquosa) concomitante à formação de aglomerados esféricos. Na seqüência da atomização tem-se a prensagem (compactação) dos suportes, secagem, esmaltação e queima em temperaturas próximas de $1100^{\circ} \mathrm{C}$, geralmente por monoqueima (único ciclo de queima com duração de 30-50 minutos).

A fabricação de revestimentos cerâmicos por extrusão é pouco praticada no Brasil, representando $2-3 \%$ da produção nacional. Os produtos obtidos nesse processo são utilizados em finalidades especiais (Corpo Técnico da Cerâmica Porto Ferreira, 2000). Esse processo é utilizado pela empresa Gail Arquitetura em Cerâmica, instalada em Guarulhos (RMSP), para a fabricação de revestimentos cerâmicos especiais através de extrusão a vácuo e queima à $1300^{\circ} \mathrm{C}$.

Processo Via Seca - Mundialmente difundido, o processo é empregado na produção de pisos vidrados de base geralmente vermelha, por monoqueima (um ciclo de queima). No Brasil, esse processo é predominante em Santa Gertrudes, com utilização de matérias-primas locais. 
Nesse processo as matérias-primas são secas, moídas, homogeneizadas, prensadas, esmaltadas e queimadas.

O processo apresenta uma série de vantagens, incluindo a economia energética (Nassetti \& Palmonari, 1997; Lolli et al., 2000), eliminação de gastos com defloculantes e aditivos e menores custos de manutenção, além do menor impacto ambiental pela menor quantidade de etapas de processamento de matérias-primas (Lolli et al., 2000).

No Brasil, as especificações técnicas para produtos cerâmicos de revestimento são definidas pelas NBR13817/97 e NBR13818/97 (ABNT, 1997a ; 1997b) (Tabela 4.7).

Tabela 4.7: Especificação para placas cerâmicas de revestimento segundo a absorção de água (AA) (NBR 13818 - ABNT, 1997b) e produto acabado, segundo CCB (1998)

\begin{tabular}{|c|c|c|c|c|c|}
\hline Grupo de AA & Conformação & AA $(\%)$ & MRF (MPa) & Dilatação térmica & $\begin{array}{l}\text { Produto Comercial } \\
\text { (CCB, 1998) }\end{array}$ \\
\hline $\mathrm{Al}$ & \multirow{4}{*}{ Extrudado } & $\leq 3$ & $\geq 23$ & Por acordo & \\
\hline Alla & & $3 \leq$ abs $\leq 6$ & $\geq 20$ & Por acordo & \\
\hline Allb & & $6 \leq a b s \leq 10$ & $\geq 17,5$ & Por acordo & \\
\hline AllI & & $a b s \geq 10$ & $\geq 8$ & Por acordo & \\
\hline Bla & \multirow{5}{*}{ Prensado } & $\leq 0,5$ & $\geq 35$ & Por acordo & Porcelanato \\
\hline $\mathrm{Blb}$ & & $0,5 \leq a b s \leq 3$ & $\geq 30$ & Por acordo & Grés \\
\hline Blla & & $3 \leq \mathrm{abs} \leq 6$ & $\geq 22$ & Por acordo & Semi-grés \\
\hline Bllb & & $6 \leq a b s \leq 10$ & $\geq 18$ & Por acordo & Semi-poroso \\
\hline BIII & & $\geq 10$ & $\geq 15$ & Por acordo & Poroso \\
\hline
\end{tabular}

\subsubsection{Argilas para cerâmica de revestimento}

As matérias-primas cerâmicas são provenientes de diferentes regiões do Brasil e raramente são obtidas por minerações de grande porte. No caso de Santa Gertrudes, as matérias-primas são os argilitos da Formação Corumbataí, com o aproveitamento de jazidas próximas, com o mínimo de transporte.

Para as empresas cerâmicas de revestimento da Região Metropolitana de São Paulo, assim como de outras regiões que utilizam processamento a úmido, as matérias-primas são trazidas de diferentes locais e mescladas durante o processo, citando-se as argilas de Tambaú ( $\mathrm{N}$ do estado), argilas plásticas de São Simão, Mogi-Mirim (NE do estado), talco e filito de Itapeva ( $\mathrm{S}$ do estado), dentre outras origens.

Como visto, na indústria cerâmica de revestimento, cujo processamento é realizado a úmido, são utilizados vários tipos de argilas, cada qual com características e funções especificas na massa cerâmica. 
A adição de bentonita (montmorillonita sódica) a partir de teores de $3 \%$ em produtos de cerâmica branca interfere na coloração da massa após a queima. Por outro lado, favorece a redução da água de prensagem em $2,2 \%$, além de conferir melhores condições de prensagem do pó semi-seco. Para produtos extrudidos e torneados a adição também permite a redução da água de amassamento, com conseqüente economia de energia do processo durante a secagem. A adição de bentonita sódica ainda contribui para a redução do uso de defloculante, constituindo também em economia (Zandonadi, 1982). Em geral, as argilas esmectíticas apresentam elevada plasticidade, podendo ser adicionadas em massas cerâmicas em pequenas proporções como sugerido por Zandonadi (1982).

Além dos ensaios para corpos-de-prova extrudados, Strazzera et al. (1997) determinaram parâmetros físicos para amostras prensadas e queimadas em temperaturas mais elevadas $\left(1080\right.$ e $\left.1100^{\circ} \mathrm{C}\right)$, visando a caracterização para cerâmica de revestimento. Florêncio (1999) também realizou ensaios de queima e determinação de parâmetros físicos para corpos-de-prova extrudados e prensados (Tabela 4.8).

Da mesma forma que para a cerâmica estrutural, buscou-se na literatura alguns parâmetros físicos de matérias-primas naturais utilizadas em cerâmica de revestimento, enfocando principalmente materiais de composição esmectítica (Tabela 4.8). 
Tabela 4.8: Compilação bibliográfica de resultados cerâmicos para argilas de diferentes composições prensadas.

\begin{tabular}{|c|c|c|c|c|c|c|}
\hline $\begin{array}{c}\text { Quant. } \\
\text { esmectita } \\
\text { (\% em peso) }\end{array}$ & Autor & Amostra & Composição Minneralógica (\% em peso) & $\begin{array}{l}\text { Temperatura } \\
\text { de queima } \\
\left({ }^{\circ} \mathrm{C}\right)\end{array}$ & $\begin{array}{l}\text { Resistôncia } \\
\text { Mecánica } \\
\text { (MPa) }\end{array}$ & $\begin{array}{l}\text { Absorçäo de } \\
\text { água } \\
\text { (\% em peso) }\end{array}$ \\
\hline \multirow{2}{*}{$E \geq 10$} & \multirow{2}{*}{$\begin{array}{l}\text { Strazzera ot } \\
\text { al. }(1997)\end{array}$} & \multirow{2}{*}{$\mathrm{SAM}^{(1)}$} & \multirow{2}{*}{$\begin{array}{c}(\text { tr-20), E (tr-29), Q (22-39), K (tr-9), } \\
\text { Ca (4-39), F (7-23) }\end{array}$} & 1000 & 16 & 27 \\
\hline & & & & 1080 & 27 & 22 \\
\hline \multirow{22}{*}{$\begin{array}{l}\text { 음 } \\
\text { v } \\
\text { 要 } \\
\text { 总 } \\
\text { 点 }\end{array}$} & Motta (1991) & $\begin{array}{c}\mathrm{T}-17 \\
\text { (S. Itararé) }\end{array}$ & 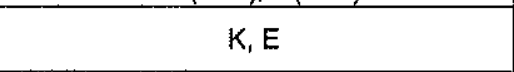 & 1100 & 13,1 & 12,4 \\
\hline & $\begin{array}{l}\text { Strazzera et } \\
\text { al. (1997) }\end{array}$ & $\mathrm{CIX}$ & $\begin{array}{c}\mathrm{I}(25-34), \mathrm{Q}(25-36), \mathrm{K}(\mathrm{tr}-14), \mathrm{Ca}(19-24), \\
\mathrm{Cl}(\mathrm{tr}-8), \mathrm{F}(\mathrm{tr}-16), \text { int, de } / / \mathrm{E}\end{array}$ & $1000-1080$ & $13-34$ & $16-23$ \\
\hline & \multirow{8}{*}{$\begin{array}{l}\text { Dondi } \\
(1999)\end{array}$} & Ranzano Fm & $\begin{array}{c}\mathrm{l}(24-31), \mathrm{Cl}(9-13), \mathrm{K}(3-4), \mathrm{E}(5), \mathrm{Q}(23-26), \\
\mathrm{F}(10-12), \mathrm{Ca}(6-20)\end{array}$ & 1000 & 14 & 20 \\
\hline & & Montepiano Fm & $\mathrm{I}(32), \mathrm{Cl}(8), \mathrm{K}(4), \mathrm{E}(6), \mathrm{Q}(28), \mathrm{F}(10), \mathrm{Ca}(5)$ & 1000 & 32 & 8 \\
\hline & & folhelho Var. & $\mathrm{I}(30), \mathrm{Cl}(7), \mathrm{K}(7), \mathrm{E}(9), \mathrm{Q}(26), \mathrm{F}(26), \mathrm{Ca}(6)$ & 1000 & 15 & 13 \\
\hline & & $\begin{array}{l}\text { folhelho Val } \\
\text { Rossenna }\end{array}$ & $\mathrm{l}(33), \mathrm{Cl}(7), \mathrm{K}(4), \mathrm{E}(8), \mathrm{Q}(28), \mathrm{F}(11), \mathrm{Ca}(2)$ & 1000 & 18 & 9 \\
\hline & & Fm Ranzano & $\begin{array}{c}\mathrm{I}(24-31), \mathrm{Cl}(9-13), \mathrm{K}(3-4), \mathrm{E}(5), \mathrm{Q}(23-26), \\
\mathrm{F}(10-12), \mathrm{Ca}(6-20)\end{array}$ & 1150 & 30 & 15 \\
\hline & & Fm Montepiano & $\mathrm{I}(32), \mathrm{Cl}(8), \mathrm{K}(4), \mathrm{E}(6), \mathrm{Q}(28), \mathrm{F}(10), \mathrm{Ca}(5)$ & 1150 & 42 & 0,5 \\
\hline & & folhelho Var. & 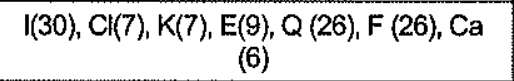 & 1150 & 35 & 4 \\
\hline & & $\begin{array}{l}\text { folhelho Val } \\
\text { Rossenna }\end{array}$ & $\mathrm{I}(33), \mathrm{Cl}(7), \mathrm{K}(4), \mathrm{E}(8), \mathrm{Q}(28), \mathrm{F}(11), \mathrm{Ca}(2)$ & 1150 & 30 & 6 \\
\hline & \multirow{6}{*}{$\begin{array}{l}\text { Florêncio } \\
(1999)\end{array}$} & \multirow{3}{*}{ Argilito } & \multirow{3}{*}{$\begin{array}{l}\text { Q, K, I, E (tr) } \\
\text { Cl, Int., F }\end{array}$} & 1050 & 13,3 & 15,5 \\
\hline & & & & 1075 & 14,2 & 14,6 \\
\hline & & & & 1100 & 15,2 & 13,1 \\
\hline & & \multirow{3}{*}{ Ritmito cinza } & \multirow{3}{*}{$\mathrm{Q}, \mathrm{K}, \mathrm{I}, \mathrm{E}, \mathrm{Cl}$, Int., F } & 1050 & 17,6 & 8,5 \\
\hline & & & & 1075 & 18,5 & 7,6 \\
\hline & & & & 1100 & 24,3 & 6,1 \\
\hline & \multirow{6}{*}{$\begin{array}{l}\text { Gaspar Jr. } \\
(1998)\end{array}$} & PcL1 & $\mathrm{I}, \mathrm{K}, \mathrm{E}, \mathrm{Q}$, hem/mag e F & 1110 & 28,3 & 8,5 \\
\hline & & PCL2 & $\mathrm{K}, \mathrm{I}, \mathrm{E}, \mathrm{Q}$, hem/mage $\mathrm{F}$ & 1110 & 13,3 & 25,0 \\
\hline & & Unicer & $K, I, E, Q$, hem/mag $\in F$ & 1110 & 23,4 & 24,1 \\
\hline & & PCL1 & $\mathrm{I}, \mathrm{K}, \mathrm{E}, \mathrm{Q}$, hem/mage $\mathrm{F}$ & 1123 & 27,1 & 6,2 \\
\hline & & PCL2 & $K, I, E, Q$, hem/mag e $F$ & 1123 & 11,4 & 23,5 \\
\hline & & Unicer & $\mathrm{K}, \mathrm{l}, \mathrm{E}, \mathrm{Q}$, hem/mag e F & 1123 & 9,9 & 8,8 \\
\hline \multirow{6}{*}{ 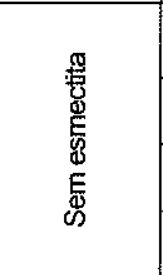 } & \multirow{2}{*}{ Motta (1991) } & T15(São Simão) & $\mathrm{K}$ & 1100 & 15,9 & 19,4 \\
\hline & & T31(Oeiras) & $\mathrm{K}$ & 1100 & 32,7 & 0,4 \\
\hline & $\begin{array}{c}\text { Strazzera et } \\
\text { al. (1997) }\end{array}$ & USS & $\begin{array}{c}\mathrm{I}(32-39), \mathrm{Q}(21-42), \mathrm{K}(\mathrm{tr}-10), \mathrm{Ca}(3-20), \mathrm{Cl} \\
(\mathrm{tr}-9), \mathrm{F}(\mathrm{tr}-12)\end{array}$ & $1000-1080$ & $20-30$ & $15-19$ \\
\hline & \multirow{2}{*}{$\begin{array}{c}\text { Gaspar Jr. } \\
\text { (1998) }\end{array}$} & $\mathrm{PcL3}$ & $\mathrm{I}, \mathrm{K}, \mathrm{Q}, \mathrm{Fe}$ hem $/ \mathrm{mag}$ & 1110 & 15,0 & 14,8 \\
\hline & & PcL3 & $\mathrm{I}, \mathrm{K}, \mathrm{Q}, \mathrm{F}$ e hem $/ \mathrm{mag}$ & 1123 & 16,4 & 12,6 \\
\hline & $\begin{array}{r}\text { Dondi } \\
(1999) \\
\end{array}$ & $\begin{array}{l}\text { folhelho } \\
\text { variegado }\end{array}$ & $\mathrm{I}(37), \mathrm{Cl}(11), \mathrm{K}(10), \mathrm{Q}(26), \mathrm{F}(8)$ & 1150 & 50 & $<1$ \\
\hline
\end{tabular}

E - esmectita; K - caulinita; I - illita; $\mathrm{Cl}$ - clorita; ; int - interestratificados; $\mathrm{Q}$ - quartzo; $\mathrm{F}$ - feldspato; Ca - carbonatos; hem/mag - hematita e magnetita; $t r$ - traço; ( ) \% em peso. Células em cinza representam materiais mais esmectíticos.

A compilação de dados demonstrou o caráter pouco previsivel do comportamento dos materiais argilosos. A presença de esmectita num material não excluiu sua aplicação, pois é o conjunto de variáveis tecnológicas que define o comportamento de uma matéria-prima.

Igualmente aos valores encontrados para peças cerâmicas extrudadas, observaram-se variações intensas entre os tipos de materiais. Porém, quando as mesmas amostras foram submetidas à conformação por extrusão e por prensagem, os parâmetros físicos obtidos para o primeiro foram sempre maiores que para o segundo. Florêncio (1999) atribuiu a elevação dos parâmetros físicos ao melhor empacotamento das partículas em peças cerâmicas extrudadas em relação às prensadas. 


\subsection{O Setor de Cimento}

Antes da abordagem do setor de cimento, foram introduzidas algumas importantes definições utilizadas na indústria de cimento, com ênfase ao uso de materiais pozolânicos como aditivos na fabricação de cimento.

Segundo a norma brasileira NBR 11172/90 (ABNT, 1990), o cimento é um aglomerante hidráulico de origem mineral, cuja característica principal é endurecer apenas pela reação com a água e, a seguir, resistir satisfatoriamente à ação da mesma.

O Cimento Portland é o mais conhecido e comercializado dentre os diversos tipos existentes. Segundo a NBR 11172/90 (ABNT, 1990), o Cimento Portland é obtido pela moagem de clínquer Portland, este constituído em sua maior parte de silicatos e/ou aluminatos de cálcio, resultantes da queima (fusão parcial) de uma mistura homogênea de calcário e argila, e que após moagem, sofre a adição de uma ou mais formas de sulfato de cálcio.

Ao Cimento Portland podem ser adicionadas quantidades especificas de materiais pozolânicos, escórias granuladas de alto-forno e materiais carbonáticos. Denomina-se Cimento Portland Comum, aquele com substituição inferior a 5\% (em massa) do clínquer Portland (ABNT, 1991a). A substituição de 6 a 14\% do clínquer resulta em Cimento Portland Composto (ABNT, 1991b) (Tabela 4.9).

Para substituições em proporções maiores, o cimento passa a receber o nome referente ao aditivo utilizado. No Cimento Portland Pozolânico, permite-se a adição de material pozolânico entre 15 a 50\%, em massa (ABNT, 1991c).

Tabela 4.9: Composição dos Cimentos Portland Comum, Composto e Pozolânico.

\begin{tabular}{|c|c|c|c|c|c|}
\hline $\begin{array}{l}\text { Cimento } \\
\text { Portland }\end{array}$ & Sigla* & Norma ABNT & $\begin{array}{c}\text { Clínquer + } \\
\text { Sulfato de } \\
\text { cálcio } \\
(\% \text { em massa })\end{array}$ & $\begin{array}{c}\text { Material } \\
\text { carbonático } \\
(\% \text { em massa) }\end{array}$ & $\begin{array}{c}\text { Material } \\
\text { Pozolânico } \\
\text { (\% em massa) }\end{array}$ \\
\hline Comum & $\mathrm{CPI}$ & NBR5732/91 & 100 & 0 & 0 \\
\hline Comum & $\mathrm{CP} 1-\mathrm{S}$ & NBR5732/91 & $99-95$ & 0 & $1-5$ \\
\hline $\begin{array}{l}\text { Composto } \\
\text { com Pozolana }\end{array}$ & $C P \|-Z$ & NBR11578/91 & $94-76$ & $0-10$ & $6-14$ \\
\hline Pozolânico & CPIV & NBR $5736 / 91$ & $85-45$ & $0-5$ & $15-50$ \\
\hline
\end{tabular}

Dentre os aglomerantes existentes destacam-se os Cimentos Portland Comum (CP I) e Composto (CP II), que representaram em 2001 cerca de $79 \%$ da produção brasileira. $O$ Brasil ocupou a $6^{\circ}$ posição dentre os produtores mundiais de cimento, com $2,30 \%$, perdendo apenas para China $(33,84 \%)$, Índia $(5,58 \%)$, Estados Unidos $(5,42 \%)$, Japão $(4,55 \%)$ e Coréia do Sul (2,94\%) (DNPM, 2001). 
O Brasil conta com 48 fábricas de cimento e 9 unidades de moagem responsáveis pela produção anual de cerca de 38,9 milhões de toneladas (Figura 4.2). Desse total, 6 fábricas de cimento e 4 unidades de moagem estão instaladas no Estado de São Paulo, e juntas produzem cerca de 550.000t/mês, pouco mais da metade da demanda do estado. Assim, parte do cimento é importado de outros estados (SNIC, 2002).

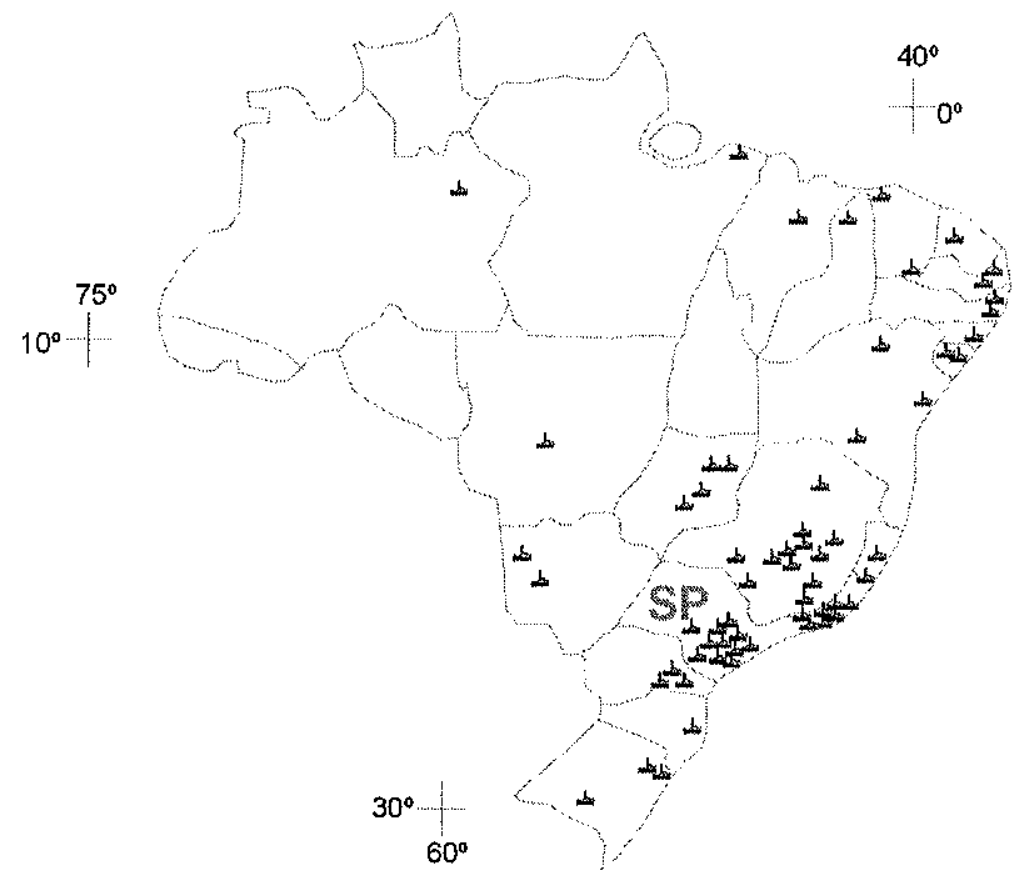

Figura 4.2: Localização das fábricas de cimento no Brasil (adaptado de SNIC, 2002).

A fabricação de Cimento Portland no Brasil iniciou-se em 1953, com a produção de 1.901.913t de Cimento Portland Comum e 128.505t de cimento de alto-forno (CP III) (SNIC, 1998). Quinze anos mais tarde, em 1969, foi iniciada a produção de Cimento Portland Pozolânico na região Sul do Brasil (Charqueadas, Rio Grande do Sul), obtido pela adição de cinzas volantes, subprodutos de usina termoelétrica (Kihara \& Esper, 1986). Argilas cauliníticas calcinadas foram inicialmente utilizadas como pozolanas durante a construção da Barragem de Jupiá (MS), llha Solteira (MS), Capivara (SP), Água Vermelha (SP) e Barragem de Tucuruí (PA), nas décadas de 70-80 (Zampieri, 1989; 1993).

Até 1992 o Cimento Portland Pozolânico no Brasil era fabricado por 13 indústrias, que juntas, produziam pouco mais de 3 mithões de toneladas. Seis dessas empresas localizavam-se na região Sul do país e utilizavam as cinzas volantes, outras 6 situavam-se no Nordeste, e uma na região Norte, onde empregavam pozolanas de argilas calcinadas. Devido à existência de grandes siderúrgicas no Sudeste do Brasil, as indústrias de cimento dessa região optaram pelo uso da escória de alto-forno (ABCP/IBRACON, 1993). 
A Figura 4.3 traz o histórico da produção do Cimento Portland Comum (CP I) e Composto (CP II) em comparação com o Cimento Portland Pozolânico (CP IV).

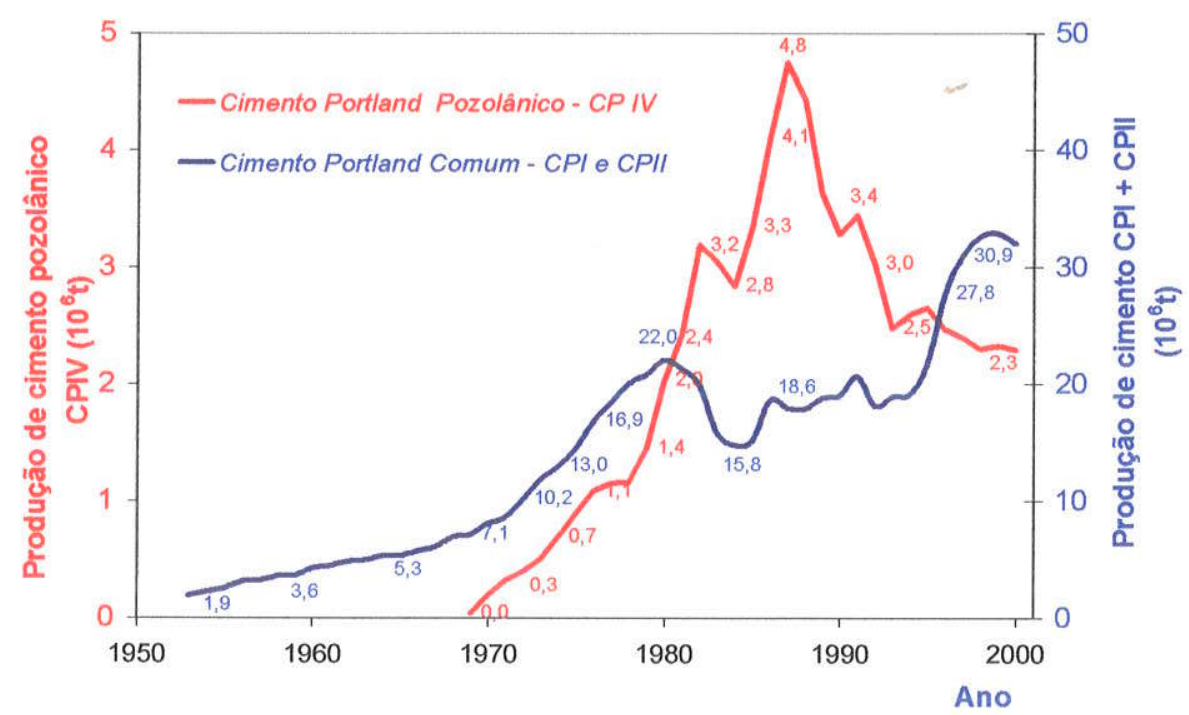

Figura 4.3: Produção nacional de Cimento Portland Comum e Composto (CP I+CP II) e Cimento Portland Pozolânico CP IV (extraído de SNIC, 1998, 1999, 2000).

Nos últimos 5 anos observou-se um crescimento acentuado na produção de Cimento Portland Comum e Composto, motivado pelo aquecimento da indústria de construção civil, principalmente de pequenas obras. Por outro lado, desde o início da década de 90, a produção de Cimento Portland Pozolânico tem se mantido num patamar próximo a 2,3 milhões de toneladas anuais, muito inferior ao da década de 80 que foi marcada pelo grande consumo de cimento em obras de engenharia (usinas hidroelétricas).

O perfil de distribuição atual do cimento é caracterizado pelo predomínio do mercado varejista, que responde pelo consumo de cerca de $70 \%$ da produção, sobre as concreteiras, que consomem menos de $15 \%$ (SNIC, 2002). Algumas indústrias, visando o importante mercado, indicam o Cimento Portland Pozolânico para mais diferentes usos (CIA de Cimento Itambé, 2001; Votorantim Cimentos S.A., 2002), a exceção do uso em obras que requerem altas resistências nas primeiras idades, como acontece na aplicação em concreto armado (ABCP, 2001).

Em virtude das vantagens econômicas, ambientais e tecnológicas que os aditivos agregam ao produto final, as indústrias têm buscado incrementar a produção de cimentos com adições de escória de alto-forno ou de pozolanas (naturais e artificiais, conforme a disponibilidade regional). 


\subsubsection{Pozolanas}

O termo pozolana tem dois significados distintos: o primeiro é atribuído às rochas piroclásticas da região de Pozzuoli (Itália), essencialmente constituídas por vidro, às vezes zeolitizado. O segundo é atribuído aos materiais inorgânicos, tanto naturais como artificiais, que reagem com o hidróxido de cálcio em meio aquoso (hidratação do clínquer do cimento Portland) (Massazza, 2001).

A definição e classificação de materiais pozolânicos no Brasil é estabelecida pela norma NBR12653/92 (ABNT, 1992):

"Materiais silicosos ou silicoaluminosos que, por si só, possuem pouca ou nenhuma atividade aglomerante, mas que, quando finamente divididos e na presença de água, reagem com o hidróxido de cálcio à temperatura ambiente para formar compostos com propriedades aglomerantes".

Existem diferentes tipos de pozolanas, classificadas de acordo com a sua natureza e as suas características.

Pozolanas $\left\{\begin{array}{l}\begin{array}{l}\text { Pozolanas Naturais: materiais de origem vulcânica, geralmente de caráter petrográfico } \\ \text { ácido }\left(-65 \% \text { de } \mathrm{SiO}_{2} \text { ) ou de origem sedimentar com atividade pozolânica }\right.\end{array} \\ \text { Pozolanas Artificiais }\left\{\begin{array}{l}\text { Argilas calcinadas: materiais provenientes de calcinação } \\ \text { de certas argilas submetidas a temperaturas, em geral, entre } \\ 500 \text { e } 900^{\circ} \mathrm{C} \text {, de modo a garantir a sua reatividade com } \\ \text { hidróxido de cálcio } \\ \text { Cinzas volantes: materiais finamente divididos que } \\ \text { resultam da combustão de carvão mineral pulverizado ou } \\ \text { granulado comatividade pozolânica } \\ \text { Outros materiais: escórias siderúrgicas ácidas, cinzas de } \\ \text { materiais vegetais, rejeito de carvão mineral }\end{array}\right.\end{array}\right.$

As características físicas e químicas necessárias para que um material seja uma pozolana são definidas pela NBR 12653/92 (ABNT, 1992), conforme indicado na Tabela 4.10. 
Tabela 4.10 - Especificações químicas e físicas para materiais pozolânicos (NBR 12653/92 - ABNT, 1992a).

\begin{tabular}{|c|c|c|c|c|}
\hline \multirow{7}{*}{ 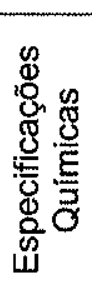 } & \multirow{2}{*}{ Propriedades } & \multicolumn{3}{|c|}{ Classe do material pozolânico } \\
\hline & & $N^{(1)}$ & $\mathrm{C}^{(2)}$ & $E^{(3)}$ \\
\hline & $\mathrm{SiO}_{2}+\mathrm{Al}_{2} \mathrm{O}_{3}+\mathrm{Fe}_{2} \mathrm{O}_{3}(\%$ min. $)$ & 70 & 70 & 50 \\
\hline & $\mathrm{SO}_{3}(\%$ máx. $)$ & 4,0 & 5,0 & 5,0 \\
\hline & Teor de umidade (máx.) & 3,0 & 3,0 & 3,0 \\
\hline & Perda ao fogo (\% máx.) & 10,0 & 6,0 & 6,0 \\
\hline & Álcalis disponiveis em $\mathrm{Na}_{2} \mathrm{O}$ (\% máx.) & 1,5 & 1,5 & 1,5 \\
\hline \multirow{5}{*}{ 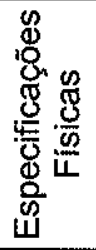 } & Material retido na peneira $45 \mu \mathrm{m}$ (\% máx.) & 34 & 34 & 34 \\
\hline & \multicolumn{4}{|c|}{ Indice de atividade pozolânica } \\
\hline & $\begin{array}{c}\text { com cimento aos } 28 \text { dias em relação ao } \\
\text { controle (\% min.) }\end{array}$ & 75 & 75 & 75 \\
\hline & com o cal aos 7 dias (MPa) & 6,0 & 6,0 & 6,0 \\
\hline & água requerida (\% máx) & 115 & 110 & 110 \\
\hline
\end{tabular}

(1) Classe N: Pozolanas naturais e artificiais que obedeçam aos requisitos aplicáveis nesta Norma, como certos materiais vulcânicos de caráter petrográfico ácido, cherts silicosos, terras diatomáceas e argilas calcinadas.

(2) Classe C: Cinza volante produzida pela queima de carvão mineral em usinas termoelétricas, que obedece aos requisitos aplicáveis nesta norma.

(3) Classe E: Qualquer pozolana cujos requisitos diferem das classes anteriores, conforme estabelecido nesta norma.

Apesar do uso milenar de argamassa de cal-pozolana e da experiência secular do cimento pozolânico, o interesse por materiais pozolânicos no mundo é recente, resultante da necessidade de fornecer alguma utilização a subprodutos industriais, como cinzas volantes de termoelétricas, cinza de casca de arroz e microssílica gerada nas aciarias (Massazza, 2001). Além desses fatores, a elevação dos custos produtivos em função do aumento dos preços do combustivel e da energia elétrica, assim como a necessidade de diminuição da emissão de $\mathrm{CO}_{2}$ durante a calcinação de carbonatos, componente essencial na fabricação do cimento, têm incentivado consideravelmente a busca por materiais pozolânicos. A Tabela 4.11 traz a compilação de uma série de vantagens de natureza tecnológica, econômica e ambiental atribuída à utilização de pozolanas. 
Tabela 4.11 Vantagens tecnológicas, econômicas e ambientais atribuídas ao uso de pozolanas.

\begin{tabular}{|c|c|c|}
\hline Tecnológicas & Econômicas & Ambientais \\
\hline $\begin{array}{l}\text { - Como a reação pozolânica é lenta, a taxa de } \\
\text { liberação de calor é lenta também. Esse fato impede } \\
\text { a fissuraçâao térmica da pasta de cimento durante a } \\
\text { cura e, consequentemente, a resistência mecânica é } \\
\text { aumentada, embora seu desenvolvimento ocorra em } \\
\text { idades superiores às de um cimento Portland comum } \\
\text { (Malhotra \& Mehta, 1996). } \\
\text { - Os produtos da reação pozolânica são bastante } \\
\text { eficientes no preenchimento de espaços capilares } \\
\text { grandes (refinamento de poros e de grãos), } \\
\text { melhorando, assim, a impermeabilidade do sistema, } \\
\text { além de contribuir para o aumento da durabilidade da } \\
\text { pasta de cimento endurecida frente a ataques } \\
\text { químicos e melhorar a resistência mecânica (Mehta, } \\
\text { 1994; Malhotra \& Mehta, 1996). }\end{array}$ & $\begin{array}{l}\text { Na composição do concreto, o cimento Portland } \\
\text { é o componente de mais alto custo. Por outro lado, } \\
\text { muito dos materiais cimenticeos e pozolânicos em } \\
\text { uso atualmente, são subprodutos ou resíduos } \\
\text { industriais, que necessitam de pouco ou nenhum } \\
\text { gasto energético para que possam ser adicionados } \\
\text { ao clínquer para a fabricação do cimento. } \\
\text { Obviamente, quando usadas como substituto parcial } \\
\text { do cimento, mundialmente entre } 20 \text { a } 60 \% \text { da massa } \\
\text { do cimento, as adiçães "minerais" podem resultar } \\
\text { numa enorme economia de energia (Malhotra \& } \\
\text { Mehta, 1996). } \\
\text { o combustivel e a energia elétrica são } \\
\text { responsáveis por } 50 \text { e 15\%, respectivamente, do } \\
\text { custo total da produção do cimento nas indústrias } \\
\text { brasileiras, enquanto que as matérias-primas e } \\
\text { demais gastos são menos impactantes na } \\
\text { composição do custo final. Em função dos aumentos } \\
\text { tarifários da energia elétrica (35\%) e aumento dos } \\
\text { derivados de petróleo (225\%), em 1999, o custo da } \\
\text { produção de cimento sofreu um aumento de } 30 \% \text { em } \\
\text { São Paulo (Bocchili, 2001). } \\
\text { - Além da redução do custo de produção, a } \\
\text { substituição de uma parcela do dínquer por material } \\
\text { pozolânico (Zampieri, 1993) permite ganhos } \\
\text { adicionais em função do aumento de produtividade } \\
\text { (maior quantidade de cimento/tonelada clínquer) e, } \\
\text { para iguais niveis de produção, em decorrência do do } \\
\text { prolongamento da vida útil dos equipamentos e da } \\
\text { própria jazida de calcário. }\end{array}$ & $\begin{array}{l}\text { - O total de material pozolânico e subprodutos } \\
\text { cimenticeos gerados anualmente pelas usinas } \\
\text { termoelétricas e siderúrgicas excede } 500 \text { milhöes de } \\
\text { toneladas. Muitos desses produtos contêm elementos } \\
\text { tóxicos, que podem ser danosos à saúde humana se } \\
\text { não forem dispostos de maneira segura. As indústrias } \\
\text { do cimento e do concreto são veiculos preferidos para } \\
\text { disposição de subprodutos "minerais" porque a } \\
\text { maioria dos metais prejudiciais pode ser incorporado } \\
\text { seguramente nos produtos de hidratação de cimento } \\
\text { (Malhotra \& Mehta, 1996; Yamamoto et al., 1997; } \\
\text { Sabir et al., 2001). } \\
\text { Acrescente-se os efeitos da redução da } \\
\text { produção, considerando que para cada tonelada de } \\
\text { cimento Portland fabricado, são lançados na } \\
\text { atmosfera 1,25 toneladas de co, da queima de } \\
\text { combustivel (0,75t) e da calcinação de carbonatos } \\
\text { (0,50t) (Wilson, 1993). Em 1997, a indústria de } \\
\text { cimento foi responsável por 7-8\% da emissão de CO }{ }_{2} \\
\text { na atmosfera, derivado de atividades antrópicas } \\
\text { (Mehta, 1998). }\end{array}$ \\
\hline
\end{tabular}




\subsubsection{A reação pozolânica}

A reação entre o material pozolânico e o hidróxido de cálcio, gerado durante a hidratação das fases do clínquer Portland, é denominada reação pozolânica. Segundo Takemoto \& Uchikawa (apud Zampieri, 1993), os produtos da reação são (Tabela 4.12):

Tabela 4.12: Fases e fórmulas produzidas durante a reação pozolânica

\begin{tabular}{|c|c|}
\hline Fase & Fórmula \\
\hline Silicato cálcico hidratado & $\mathrm{C}-\mathrm{S}-\mathrm{H}^{*}$ \\
\hline $\begin{array}{c}\text { Solução sólida carboaluminato- } \\
\mathrm{C}_{4} \mathrm{AH}\end{array}$ & $\mathrm{C}_{4} \mathrm{AH} \mathrm{H}_{12}$ \\
\hline Gehlenita hidratada & $\mathrm{C}_{2} \mathrm{ASH} \mathrm{H}_{8}$ \\
\hline Hidrogranada & $\mathrm{C}_{3}(\mathrm{~A}, \mathrm{~F}) \mathrm{H}_{6}$ \\
\hline
\end{tabular}

* Abreviação empregada pelo setor de cimento, na qual C, S, F, Ae $\mathrm{H}$, representam $\mathrm{CaO}, \mathrm{SiO}_{2}, \mathrm{Fe}_{2} \mathrm{O}_{3}, \mathrm{Al}_{2} \mathrm{O}_{3}$ e $\mathrm{H}_{2} \mathrm{O}$, respectivamente. C-S-H:CaO. $\mathrm{SiO}_{2} \cdot \mathrm{H}_{2} \mathrm{O} ; \mathrm{CH}: \mathrm{Ca}(\mathrm{OH})_{2}$.

Para compreender as diferenças entre as reações pozolânica e de hidratação do cimento, Metha (1994) descreveu como:

$$
\begin{array}{cc}
\mathrm{C}_{3} \mathrm{~S}+\mathrm{H} \stackrel{\text { Rápida }}{\rightarrow} \mathrm{C}-\mathrm{S}-\mathrm{H}+\mathrm{CH}^{*} & \text { Reação de hidratação das fases do cimento } \\
\text { Pozolana }+\mathrm{CH}+\mathrm{H} \stackrel{\text { Lenta }}{\rightarrow} \mathrm{C}-\mathrm{S} \cdot \mathrm{H} & \text { Reação pozolânica }
\end{array}
$$

Nessas reações, verifica-se que é produzido $\mathrm{Ca}(\mathrm{OH})_{2}$ durante a hidratação das fases do clinquer de Cimento Portland, cuja presença em alguns meios quimicamente agressivos facilita $\mathrm{o}$ ataque químico ao concreto. Por outro lado, $\mathrm{OCa}(\mathrm{OH})_{2}$ reage com a pozolana adicionada, produzindo mais $\mathrm{C}-\mathrm{S}-\mathrm{H}$, um importante componente na determinação das propriedades da pasta, além de outros produtos secundários (Mehta, 1994).

Segundo Zampieri (1993), em meios fortemente alcalinos, como em pastas de cimento, a reação entre a pozolana e o hidróxido de cálcio é favorecida, uma vez que a solubilidade dos componentes $\mathrm{SiO}_{4}^{-4}$ e $\mathrm{AlO}_{2}^{-}$é aumentada. Esse meio é também caracterizado pela grande disponibilidade de cálcio que, por sua vez, combina-se com os íons de silício e alumínio para formação de aluminatos, silicatos e aluminossilicatos cálcicos hidratados, típicos da reação pozolânica. O mesmo autor concluiu que a proporção e a seqüência de cristalização das fases hidratadas dependem da reatividade e da composição química da pozolana, do tempo de reação considerado e, também, da relação pozolana/cal. 


\subsubsection{Argilas pozolânicas}

Mielenz et al. (1951), propuseram uma classificação das pozolanas naturais por atividade-tipo, colocando os materiais em ordem decrescente de reatividade química: (1) vidro vulcânico > (2) opala > (3) argilas (caulinita>montmorillonita>illita>vermiculita>paligorskita) > (4) zeólita > óxidos hidratados de alumínio > (6) não pozolânicos.

No Brasil, desde o primórdios da fabricação de cimento pozolânico, as indústrias utilizamse de pozolanas de argilas calcinadas e cinzas volantes. A exploração comercial de pozolanas naturais ainda não ocorre.

Montanheiro (1999) reconheceu na região de Leme/Casa Branca e Araçatuba (SP), depósitos organogênicos atuais de frústulas e espículas, constituídos parcialmente por sílica amorfa. Os indices de atividade pozolânica com cimento obtidos para esses materiais atenderam às especificações estabelecidas pela NBR12653/92 (ABNT, 1992a). Outra ocorrência de pozolana natural representada por um argilito composto por caulinita, muscovita, quartzo e microclínio (amostra TM-97), foi determinada pelo mesmo autor na região de Franca-Pedregulho (SP).

\subsubsection{Ativação térmica de argilas}

Em geral, a atividade pozolânica de argilas sem calcinação não atinge o índice mínimo recomendado pela NBR 12653/92 (ABNT, 1992a). Com a calcinação, em temperaturas superiores a $550^{\circ} \mathrm{C}$, as argilas pouco reativas sofrem alterações estruturais, passando a fases mais reativas.

A reação química entre materiais sílico-aluminosos e a cal depende da forma como o Si e - Al se apresentam nas fases componentes. A princípio, a reatividade química em meio alcalino $\left(\mathrm{Ca}(\mathrm{OH})_{2}\right)$ é proporcional ao desarranjo cristalino, de forma que materiais com estruturas amorfas ou desordenadas atomicamente apresentam atividade pozolânica mais intensa que materiais melhor cristalinizados.

A atividade pozolânica de argilas calcinadas é estritamente dependente de uma série de fatores que devem ser considerados. A composição mineralógica, a cristalinidade, a temperatura ótima de calcinação são algumas das importantes variáveis que devem ser determinadas durante a caracterização de uma pozolana. 
O tratamento térmico de argilominerais provoca o desarranjo cristalino a partir da desidroxilação, que pode ocorrer desde $550^{\circ} \mathrm{C}$, no caso de caulinita, a temperaturas superiores a $900^{\circ} \mathrm{C}$ para illitas, por exemplo.

Segundo Pera (2001), o comportamento dos argilominerais durante o aquecimento depende da estrutura, tamanho dos cristais e da cristalinidade do material. Depois da eliminação da água adsorvida, que acontece por volta de $100^{\circ} \mathrm{C}$, a caulinita perde hidroxila de sua estrutura à cerca de $550^{\circ} \mathrm{C}$. A natureza do produto da desidroxilação da caulinita pode ser uma mistura amorfa de sílica e alumina, podendo apresentar a estrutura residual da caulinita em alguns casos; esse produto é denominado metacaulinita. Sob temperaturas superiores à $900^{\circ} \mathrm{C}$, a metacaulinita passa a compor uma mistura de novas fases cristalinas, constituída de sílica livre e mulita.

A literatura trata fartamente de transformações térmicas e estruturais de caulinitas. A desidroxilação - perda da água estrutural - ocorre entre 550 e $700^{\circ} \mathrm{C}$, quando se forma a metacaulinita (Mackenzie e Babushkin et al. apud He et al. 1994), porém, somente entre 650 e $850^{\circ} \mathrm{C}$, as argilas cauliníticas apresentam propriedades pozolânicas interessantes, pois nesse intervalo é produzida grande quantidade de material amorfo (Ambroise et al., 1992).

He et al. (2000) descrevem as transformações ocorridas durante a calcinação de um argilomineral de camada mista mica/esmectita sintética. Basicamente, as mudanças observadas são as mesmas da caulinita, porém em temperaturas diferentes. A desidroxilação ocorre entre $560^{\circ} \mathrm{C}$ e $760^{\circ} \mathrm{C}$, intervalo no qual o material tem comportamento metaestável, com estrutura remanescente. A partir de $960^{\circ} \mathrm{C}$ ocorre a destruição da estrutura cristalina, com aparecimento de novas fases, como $\mathrm{\gamma A}_{2} \mathrm{O}_{3}$.

He et al. (1995a) confirmaram que a calcinação que danifica e desarranja a estrutura cristalina do argilomineral é muito importante na ativação das propriedades pozolânicas. Segundo esses autores, a atividade pozolânica pode ser avaliada por dois métodos diferentes da reação com $\mathrm{Ca}(\mathrm{OH})_{2}$ e cimento, tradicionalmente utilizados:

a) Identificação da presença de fase amorfa, evidenciada em difratograma de raios $X$, pelo alargamento de picos.

b) Quantificação do conteúdo de $\mathrm{Al}$ e Si álcali-solúvel, que reflete a presença de aluminossilicatos ativos no material, disponível para reação com $\circ \mathrm{Ca}(\mathrm{OH})_{2}$. As solubilidades do Al e Si aumentam com a calcinação, quando os argilominerais são submetidas a temperaturas inferiores a $800-900^{\circ} \mathrm{C}$, devido à destruição da estrutura 
cristalina. Em temperaturas mais elevadas, a solubilidade é abruptamente reduzida pela cristalização de mulita, que consome três vezes mais $\mathrm{Al}$ que Si.

A determinação da temperatura de calcinação pode ser feita com base na interpretação de curvas termogravimétricas (ATG) e termodiferenciais (ATD), nas quais são reconhecidas as temperaturas específicas de perdas de água estrutural, desidroxilação e formação de novas fases. Somam-se a esses ensaios, análises por difração de raios $X$, que conferem maior segurança na identificação dos produtos de calcinação.

Os argilominerais apresentam comportamentos térmicos distintos. As temperaturas das transformações variam também entre as espécies do mesmo grupo de argilas, como ocorre, por exemplo, entre os tipos de esmectita (montmorillonita, nontronita, hectorita/saponita) (Figura 4.4), uma vez que dependem das estruturas cristalinas e do quimismo mineral.

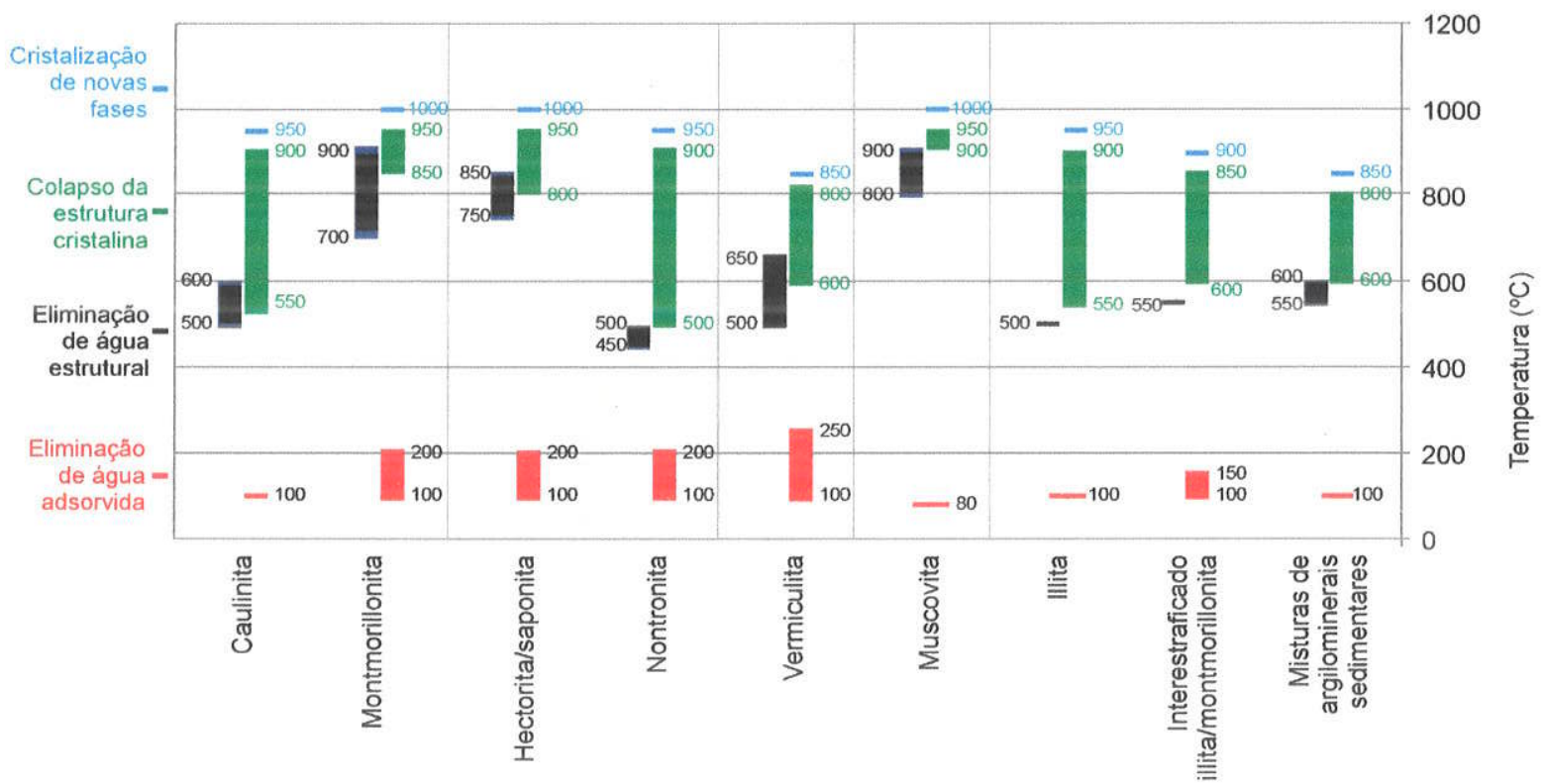

Figura 4.4: Comportamento térmico de argilominerais (baseado em dados de Smyktaz-Kloss, 1974)

A desestruturação cristalina em arranjos dioctaédricos ocorre em temperaturas mais elevadas que em trioctaédricos (Smyktaz-Kloss, 1974; Souza Santos, 1989). Dessa forma, as espécies montmorillonita e beidellita (esmectitas dioctaédricas) são ativadas em temperaturas mais elevadas que a nontronita (esmectita trioctaédrica). 


\subsubsection{Atividade pozolânica de argilas}

No Brasil, a determinação de atividade pozolânica é realizada segundo recomendações de duas normas técnicas: NBR5751/92 - Materiais pozolânicos - Determinação da atividade pozolânica - Índice de atividade pozolânica com cal (ABNT, 1992b); e NBR5752/92 - Materiais pozolânicos - Determinação da atividade pozolânica com cimento Portland - Índice de atividade pozolânica com cimento (ABNT, 1992c). Para o entendimento do comportamento dos materiais estudados frente aos ensaios, buscou-se na literatura mundial, índices de atividades pozolânicas com cal e com cimento de diferentes argilas, tomando-se a cautela de observar o método empregado.

\subsubsection{Atividade pozolânica com cal}

Segundo Zampieri (1993), os índices de atividade pozolânica dependem da proporção pozolana/cal, apesar do conhecimento de que a capacidade de fixação do $\mathrm{Ca}(\mathrm{OH})_{2}$ difere conforme a natureza do material. Esse autor, buscando determinar uma relação ótima entre os reagentes, e com isso melhor avaliar a potencialidade da atividade pozolânica, desenvolveu uma série de estudos variando as relações cal/pozolana (argilas cauliníticas e esmectíticas calcinadas). $O$ autor verificou, de maneira geral, que na relação pozolana/cal=1 há excesso de $\mathrm{Ca}(\mathrm{OH})_{2}$, o que resulta em desempenho mecânico nem sempre satisfatório. Os melhores resultados obtidos foram nas reações com 10 a $30 \%$ de $\mathrm{Ca}(\mathrm{OH})_{2}$.

Diferentes autores (Zampieri, 1989; Metha, 1994) sustentaram que a reatividade dos materiais argilosos ativados termicamente é decrescente na seguinte ordem: caulinita mal cristalizada > caulinita bem cristalizada > esmectitas > micas mal cristalizadas > micas bem cristalizadas. No entanto, a presença de impurezas tem grande influência no desempenho mecânico de corpos-de-prova preparados com argila calcinada e cal.

Há uma certa discordância na literatura quanto ao período de cura para a determinação do índice de atividade pozolânica com cal; a maioria dos autores consultados preferiu o período de cura de 28 dias. Zampieri (1993) justificou a escolha pela concordância com os ensaios normatizados de cimento e, também, por acreditar que após esse período o sistema atinge o equilíbrio. Por outro lado, há um consenso quanto a relação pozolana/ cal, que deve ser padronizada em 1:1 (Tabela 4.13).

A Figura 4.5 apresenta graficamente os índices de atividade pozolânica com cal para um período de cura de 28 dias. 
Tabela 4.13: Atividade pozolânica com cal $\left(\mathrm{Ca}(\mathrm{OH})_{2}\right)$, após 28 dias de cura, relação pozolana/cal $=1$ (células em cinza representam amostras com maiores conteúdos de esmectita).

\begin{tabular}{|c|c|c|c|c|c|}
\hline Autor & Amostra & $\begin{array}{c}\text { Temp. }\left({ }^{\circ} \mathrm{C}\right) l \\
\text { tempo de } \\
\text { calcinação(h) }\end{array}$ & $\begin{array}{c}\text { Composição mineralógica } \\
(\% \text { em peso })\end{array}$ & Procedimento & $\begin{array}{l}\text { Resistência à } \\
\text { compressão } \\
\text { (MPa) }\end{array}$ \\
\hline \multirow{3}{*}{ Murat (1983) } & $\begin{array}{l}\text { K1-caulinita } \\
\text { bem } \\
\text { cristalizada }\end{array}$ & $730 / 6 \mathrm{~h}$ & caulinita $(63,0)$; quartzo $(37,0)$ & sem descrição & 4,51 \\
\hline & $\begin{array}{l}\text { K2-caulinita } \\
\text { mal } \\
\text { cristalizada }\end{array}$ & $730 / 6 \mathrm{~h}$ & caulinita $(98,0)$;quartzo $(1-2,0)$ & sem descrição & 9,96 \\
\hline & $\mathrm{K} 3$ & $730 / 6 \mathrm{~h}$ & $\begin{array}{c}\text { caulinita }(85,0) \text {; quartzo }(5,0) ; \\
\text { muscovita }(10,0)\end{array}$ & sem descrição & 5,85 \\
\hline \multirow{4}{*}{$\begin{array}{l}\text { Zampieri } \\
(1989)\end{array}$} & $\begin{array}{l}\text { caulinita bem } \\
\text { cristalizada }\end{array}$ & $700-900 / 2 h$ & $\begin{array}{l}\text { caulinita }(93,5) \text {; mica }(5,5) \\
\text { quartzo }(0,5) \text {; gibsita }(0,5)\end{array}$ & \multirow{4}{*}{$\begin{array}{c}\text { Água } / \mathrm{s} \text { olido }=0,65 \\
\text { cal } / \text { pozolana }=1\end{array}$} & $15-20$ \\
\hline & $\begin{array}{l}\text { caulinita mal } \\
\text { cristalizada }\end{array}$ & $700-900 / 2 h$ & $\begin{array}{c}\text { caulinita }(88,5) ; \text { mica }(10,0) \\
\text { quartzo }(1,5)\end{array}$ & & $15-24$ \\
\hline & $\begin{array}{c}\text { argila } \\
\text { esmectitica }\end{array}$ & $700-900 / 2 \mathrm{~h}$ & 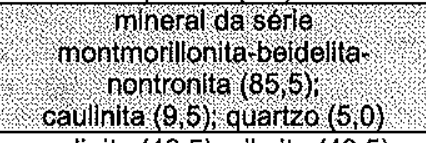 & & 5,0 \\
\hline & $\begin{array}{c}\text { argila } \\
\text { aluminosa }\end{array}$ & $700-900 / 2 h$ & $\begin{array}{c}\text { caulinita }(46,5) ; \text { gibsita }(43,5) ; \\
\text { mica }(9,0) ; \text { quartzo }(1,0)\end{array}$ & & $11-15$ \\
\hline \multirow{4}{*}{$\begin{array}{l}\text { Ambroise et } \\
\text { al. (1992) }\end{array}$} & A & $800 / 5 h$ & $\begin{array}{c}\text { caulinita }(92,5) ; \text { mica }(4,0) \\
\text { anatásio }(3,0) ; \text { quartzo }(0,5)\end{array}$ & $\begin{array}{l}\text { Agua/sollido }=0,72 \\
\mathrm{cal} / \text { pozolana }=1\end{array}$ & 25,9 \\
\hline & $F$ & $800 / 5 \mathrm{~h}$ & $\begin{array}{l}\text { caulinita }(92,0) ; \text { quartzo }(4,0) ; \\
\text { muscovita }(3,0) ; \text { anatásio }(1,0)\end{array}$ & $\begin{array}{l}\text { Agualsólido }=0,68 \\
\text { cal/pozolana }=1\end{array}$ & 24,1 \\
\hline & $\mathrm{O}$ & $800 / 5 h$ & $\begin{array}{c}\text { Illita }(37,5) ; \text { quartzo }(29,0) ; \\
\text { caulinita }(19,0) ; \text { carbonatos }(8,0) \text {; } \\
\text { Na interestratificado }(4,0) ; \\
\text { anatásio }(1,0)\end{array}$ & $\begin{array}{l}\text { Agua/sólido }=0,50 \\
\text { cal/pozolana }=1\end{array}$ & 10,7 \\
\hline & $S$ & $800 / 5 \mathrm{~h}$ & $\begin{array}{c}\text { illita }(30,0) ; \text { caulinita }(29,0) ; \\
\text { quartzo }(18,0) ; \text { carbonatos } \\
(11,0) ; \\
\text { Na-Mg interestratificado }(5,0) \\
\text { anatásio }(1,0)\end{array}$ & $\begin{array}{l}\text { Agua/sólido }=0,50 \\
\text { cal/pozolana }=1\end{array}$ & 12,0 \\
\hline \multirow{3}{*}{$\begin{array}{c}\text { Zampierì } \\
(1993)\end{array}$} & A & \multirow{3}{*}{$800 / 30 \mathrm{~min}$} & 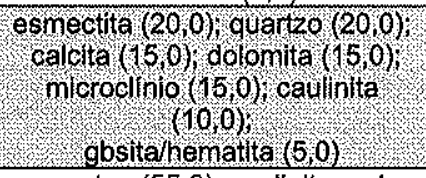 & \multirow{3}{*}{ NBR5751/77 } & 12,3 (7dias) \\
\hline & B & & $\begin{array}{c}\text { quartzo }(55,0) ; \text { caulinita mal } \\
\text { cristalizada }(40,0) \\
\text { clorita/gibsita }(5)\end{array}$ & & 12,9 (7dias) \\
\hline & C & & $\begin{array}{l}\text { caulinita bem cristalizada }(90,0) \text {; } \\
\text { mica }(8,0) \text {; quartzo }(2,0)\end{array}$ & & 11,1 (7dias) \\
\hline \multirow{3}{*}{$\begin{array}{l}\text { Zampieri } \\
(1993)\end{array}$} & A & \multirow{3}{*}{$800 / 30 \mathrm{~min}$} & 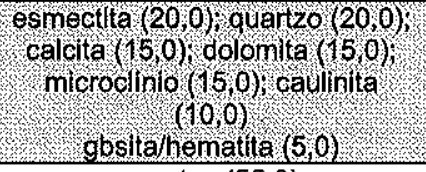 & $\begin{array}{l}\text { Água } / \text { sólido }=0,50 \\
\text { cal/pozolana }=1\end{array}$ & $\sim 10$ \\
\hline & B & & $\begin{array}{l}\text { quartzo }(55,0) \\
\text { caulinita mal cristalizada }(40,0) \\
\text { clorita/gibsita }(5,0)\end{array}$ & $\begin{array}{l}\text { Agua/sólido }=0,50 \\
\text { cal/pozolana }=1\end{array}$ & $\sim 8$ \\
\hline & C & & $\begin{array}{l}\text { caulinita bem cristalizada }(90,0) \\
\text { mica }(8,0) \text {; quartzo }(2,0)\end{array}$ & $\begin{array}{l}\text { Agua/sólido }=0,65 \\
\text { cal } / \text { pozolana }=1\end{array}$ & -19 \\
\hline \multirow{11}{*}{$\begin{array}{l}\text { Llebig \& } \\
\text { Althaus } \\
\text { (1997) }\end{array}$} & \multirow{6}{*}{ bentonita } & $500 / 5 \mathrm{~h}$ & \multirow{11}{*}{$\begin{array}{c}\text { caulinita - principal } \\
\text { esmectita/illita/quartzo - } \\
\text { acessórios }\end{array}$} & \multirow{11}{*}{$\begin{array}{c}\text { cal/pozolana }=1 \\
3 \text { partes de areia } \\
\text { para 1parte de } \\
\text { argamassa } \\
\text { pozolana/cal }\end{array}$} & 0,2 \\
\hline & & $600 / 5 \mathrm{~h}$ & & & 0,4 \\
\hline & & $1000 / 5 \mathrm{~h}$ & & & 0,5 \\
\hline & & $900 / 5 \mathrm{~h}$ & & & 0,8 \\
\hline & & $700 / 5 \mathrm{~h}$ & & & 1,4 \\
\hline & & $800 / 5 \mathrm{~h}$ & & & 1,9 \\
\hline & \multirow{5}{*}{ caulinita } & $1000 / 5 \mathrm{~h}$ & & & 0,8 \\
\hline & & $900 / 5 \mathrm{~h}$ & & & 1,5 \\
\hline & & $600 / 5 \mathrm{~h}$ & & & 1,7 \\
\hline & & $700 / 5 h$ & & & 1,8 \\
\hline & & $\begin{array}{l}500 / 5 h \\
800 / 5 h\end{array}$ & & & $\begin{array}{l}1,8 \\
1,8\end{array}$ \\
\hline \multirow{2}{*}{$\begin{array}{c}\text { Montanheiro } \\
(1999)\end{array}$} & TM-97 & Natural & $\begin{array}{l}\text { quarzto, microclínio, muscovita, } \\
\text { caulinita }\end{array}$ & \multirow[t]{2}{*}{ NBR5751/92 } & 7,7 (7dias) \\
\hline & TM-107 & $800 / 1 \mathrm{~h}$ & caulinita, quartzo, muscovita & & 15.9 (7dias) \\
\hline
\end{tabular}




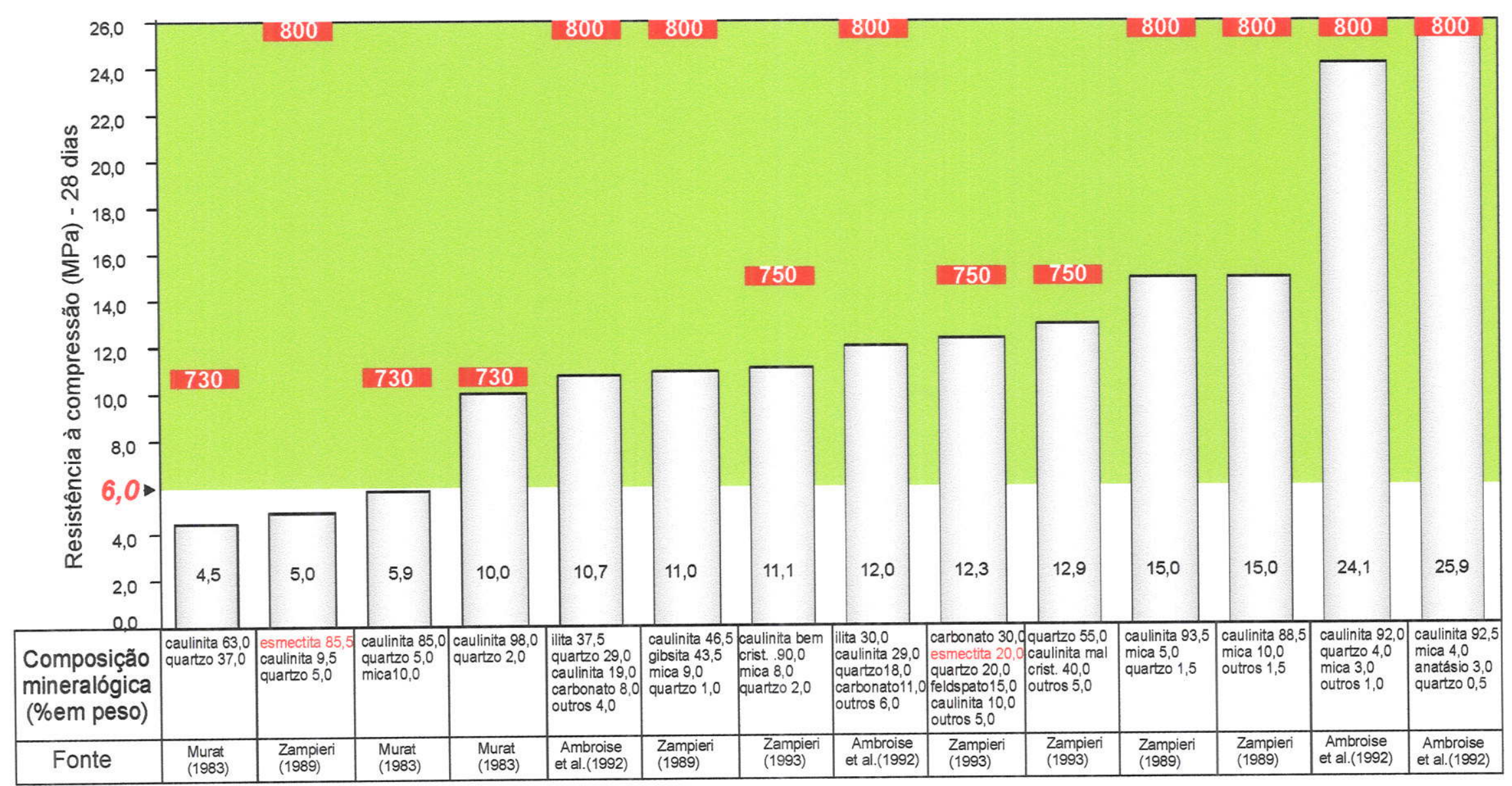

830 Temperatura de calcinação $\left({ }^{\circ} \mathrm{C}\right)$

Figura 4.5: Índices de Atividade Pozolânica com Cal aos 28 dias de cura para diferentes tipos de argilas. A região em verde representa conformidade com a norma NBR12653/92 (ABNT, 1992a) 


\subsubsection{Atividade pozolânica com cimento}

A determinação do índice de atividade pozolânica com cimento é mais precisa para a caracterização física, uma vez que a pozolana substitui parte do clínquer Portland na preparação do cimento aditivado, como ocorre industrialmente.

Segundo Zampieri (1993), a máxima resistência mecânica dos cimentos aditivados com pozolanas não se relaciona unicamente com o equilíbrio entre a capacidade de fixação do hidróxido de cálcio e a pozolana. A resistência adquirida decorre das novas fases geradas pela hidratação dos componentes do clínquer no cimento e da reação pozolânica.

A substituição parcial do clínquer pela pozolana deve obedecer à proporções estequiométricas. $O$ desenvolvimento das melhores resistências depende de uma reação sem reagentes em excesso, como observado por Zampieri (1993), as reações ideais ocorreriam quando o $\mathrm{Ca}(\mathrm{OH})_{2}$ representasse cerca de $30 \%$ da massa de pozolana.

He et al. (1995b) determinaram os índices de atividade pozolânica com cimento de cinco argilominerais padrões da American Clay Minerals Society: illita, montmorillonita cálcica, montmorillonita sódica, camada mista de mica/esmectita e sepiolita, além de uma amostra de caulinita bem cristalizada. Segundo esses autores, 0 índice de atividade pozolânica obtido para amostras naturais obedeceu a seguinte ordem: montmorillonita cálcica > caulinita > illita > montmorillonita sódica > camada mista mica/esmectita > sepiolita. No entanto, somente a montmorillonita cálcica constituiria uma pozolana natural, segundo a especificação brasileira. Após a ativação térmica, os desempenhos mecânicos foram consideravelmente melhorados, tornando-as pozolanas artificiais (Figura 4.6). 


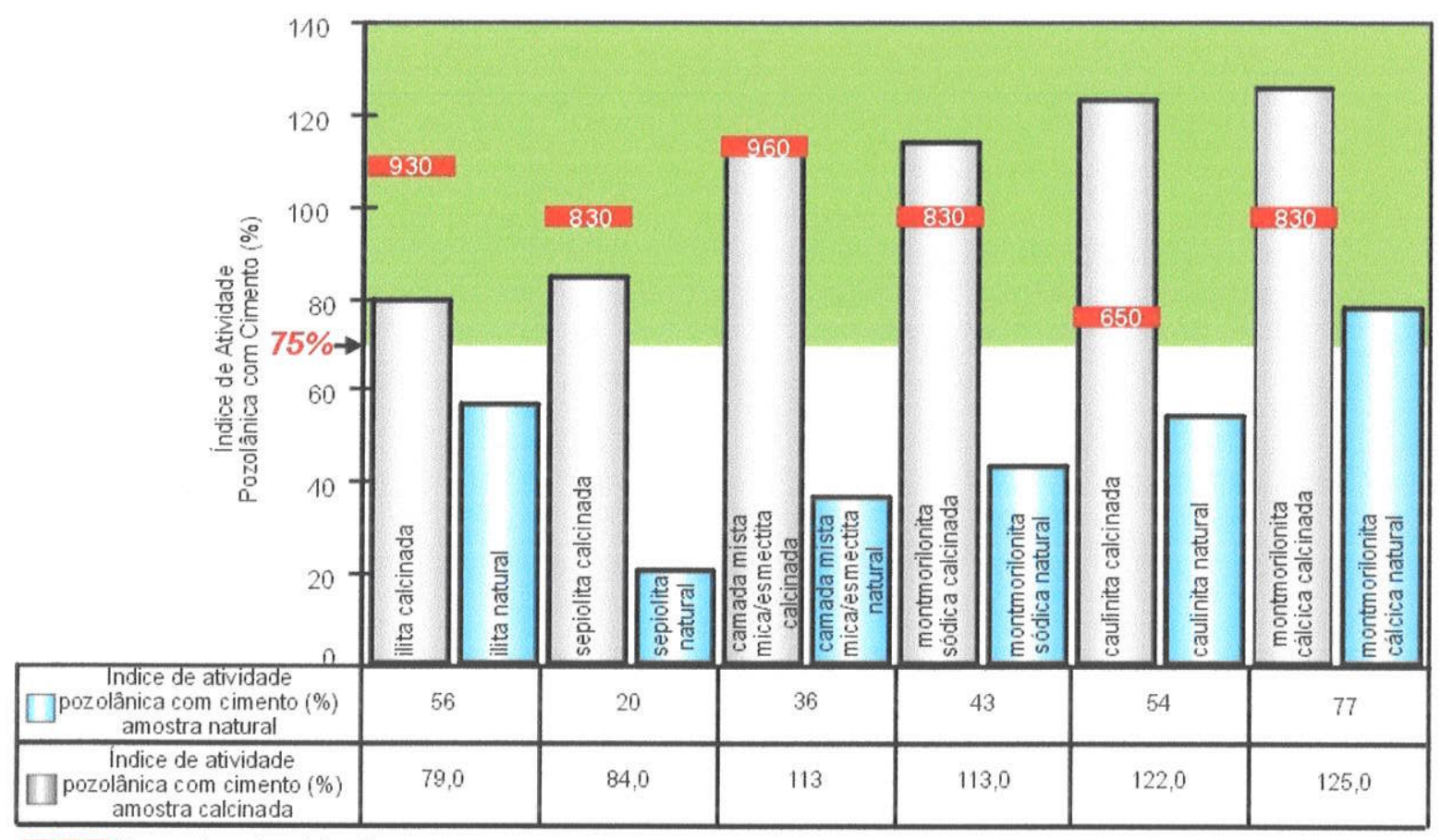

830 Temperatura de calcinaçăo

Figura 4.6: Índice de Atividade Pozolânica com cimento aos 28 dias de cura para argilas naturais e calcinadas (He et al., 1995a). A região em verde representa conformidade com a norma ABNT

NBR12653/92 (1992a).

Os resultados compilados de diversos autores confirmaram a elevação do desempenho mecânico com o aumento da temperatura de calcinação, sendo isso mais evidente para amostras com esmectita e com illita.

No Brasil, Zampieri (1993) caracterizou três tipos de argilas: uma esmectítica, uma caulinítica com muito quartzo e uma predominantemente caulinítica.

Com vistas a avaliar comparativamente os dados dos materiais de estudos com os de literatura, realizou-se uma compilação de índices obtidos para diversas argilas (Tabela 4.14). 
Tabela 4.14: Índices de atividade pozolânica com cimento aos 28 dias de cura para argilas calcinadas (em cinza, amostras com esmectita)

\begin{tabular}{|c|c|c|c|c|c|}
\hline Autor & Amostra & $\begin{array}{c}\text { Temperatural } \\
\text { tempo de } \\
\text { calcinação } \\
\left({ }^{\circ} \mathrm{C}\right) \\
\end{array}$ & Composição (\% em peso) & $\begin{array}{l}\text { Indice de atividade } \\
\text { pozolânica com } \\
\text { cimento }(\%)\end{array}$ & $\begin{array}{c}\text { Material } \\
\text { pozolânico } \\
\text { (\% em peso) }\end{array}$ \\
\hline \multirow[b]{2}{*}{ 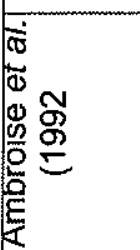 } & \multirow[b]{2}{*}{0} & \multirow[b]{2}{*}{$800 / 5 \mathrm{~h}$} & \multirow{2}{*}{$\begin{array}{c}\text { illita }(37,5) \\
\text { quartzo }(29,0) \\
\text { caulinita }(19,0) \\
\text { carbonatos }(8,0) \\
\text { Na interestratificado }(4,0) \\
\text { anatásio }(1,0)\end{array}$} & 91,6 & 20 \\
\hline & & & & 91,6 & 30 \\
\hline \multirow{6}{*}{ 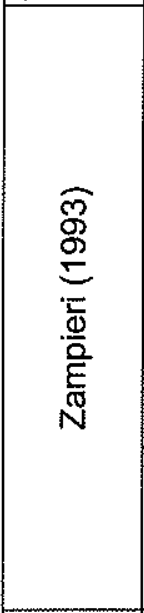 } & \multirow[b]{2}{*}{ A } & \multirow{6}{*}{$800 / 30 \mathrm{~min}$} & \multirow{2}{*}{$\begin{array}{c}\text { esmectita }(20,0) \\
\text { quartzo }(20,0) \\
\text { calcita }(15,0) \\
\text { dolomita }(15,0) \\
\text { microclinio }(15,0) \\
\text { caulinita }(10,0) \\
\text { gbsita/hematita }(5,0)\end{array}$} & 110 & 20 \\
\hline & & & & 109 & 30 \\
\hline & \multirow[b]{2}{*}{ B } & & \multirow{2}{*}{$\begin{array}{c}\text { quartzo }(55,0) \\
\text { caulinita mal cristalizada } \\
(40,0) \\
\text { clorita/gibsita (5) }\end{array}$} & 86 & 20 \\
\hline & & & & 77 & 30 \\
\hline & \multirow[b]{2}{*}{ C } & & \multirow{2}{*}{$\begin{array}{c}\text { caulinita bem cristalizada } \\
(90,0) \\
\text { mica }(8,0) \\
\text { quartzo }(2,0)\end{array}$} & 110 & 20 \\
\hline & & & & 110 & 30 \\
\hline \multirow{5}{*}{ 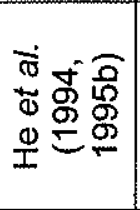 } & \multirow{5}{*}{$\begin{array}{l}\text { caulinita } \\
\text { bem } \\
\text { cristaliza } \\
\text { da }\end{array}$} & natural & \multirow{5}{*}{$\begin{array}{c}\text { caulinita }(82,0) \\
\text { mica }(12,0) \\
\text { quartzo }(3,8) \\
\text { microclinio }(2,3 \%)\end{array}$} & 75 & \multirow{5}{*}{30} \\
\hline & & $550 / 100 \mathrm{~min}$ & & 120 & \\
\hline & & $650 / 100 \mathrm{~min}$ & & 117 & \\
\hline & & $800 / 100 \mathrm{~min}$ & & 131 & \\
\hline & & $950 / 100 \mathrm{~min}$ & & 125 & \\
\hline \multirow{4}{*}{ 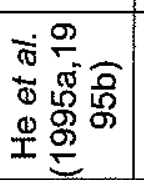 } & \multirow{4}{*}{ illita } & natural & \multirow{4}{*}{$\begin{array}{c}\text { illita }(83,0) \\
\text { feldspato }(12,0) \\
\text { quartzo }(4,0) \\
\text { calcita }(1,0)\end{array}$} & 56 & \multirow{4}{*}{30} \\
\hline & & $650 / 100 \mathrm{~min}$ & & 57 & \\
\hline & & $790 / 100 \mathrm{~min}$ & & 64 & \\
\hline & & $920 / 100 \mathrm{~min}$ & & 79 & \\
\hline \multirow{2}{*}{ 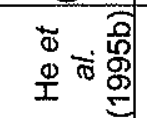 } & \multirow{2}{*}{ sepiolita } & natural & \multirow{2}{*}{ sepiolita } & 20 & 30 \\
\hline & & 830 & & 84 & 30 \\
\hline \multirow{8}{*}{$\frac{6}{\mathscr{g}}$} & \multirow{4}{*}{$\begin{array}{l}\text { montmo- } \\
\text { rillonita } \\
\text { sódica }\end{array}$} & natural & \multirow{4}{*}{$\begin{array}{l}\text { montmorillonita sódica } \\
\text { (74,0) } \\
\text { microclinio }(17,0) \\
\text { quartzo }(5,0) \\
\text { calcita }(3,0)\end{array}$} & 43 & \multirow{8}{*}{30} \\
\hline & & $730 / 100 \mathrm{~min}$ & & 82 & \\
\hline & & $830 / 100 \mathrm{~min}$ & & 113 & \\
\hline & & $930 / 100 \mathrm{~min}$ & & 98 & \\
\hline & \multirow{4}{*}{\begin{tabular}{|c|} 
montmo- \\
rillonita \\
cálcica
\end{tabular}} & natural & \multirow{4}{*}{$\begin{array}{l}\text { montmorillonita cálcica } \\
(75 \%) \\
\text { opala + quartzo }(25)\end{array}$} & 77 & \\
\hline & & $730 / 100 \mathrm{~min}$ & & 102 & \\
\hline & & $830 / 100 \mathrm{~min}$ & & 125 & \\
\hline & & $930 / 100 \mathrm{~min}$ & & 108 & \\
\hline \multirow{4}{*}{ 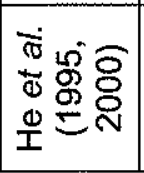 } & & natural & & 36 & \\
\hline & mista & 560 & camada mista & 70 & 30 \\
\hline & micales- & 760 & micalesmectita $(100)$ & 70 & \\
\hline & & 960 & & 113 & \\
\hline
\end{tabular}


He et al. (1994) concluiram que a melhor temperatura de calcinação para argila caulinítica é $550^{\circ} \mathrm{C}$, uma vez que conjuga dois importantes fatores: resultado técnico satisfatório e a menor temperatura de ativação (menor custo energético) (Figura 4.7). Segundo He et al. (1995b), a illita natural é praticamente inerte em misturas com cimento, e calcinações a 650 e $790^{\circ} \mathrm{C}$ não foram eficientes para a sua ativação, tendo formado uma pozolana de moderada atividade $(79 \%)$ somente à $920^{\circ} \mathrm{C}$. Zampieri (1989) obteve resultados satisfatórios para argilas esmectíticas calcinadas na temperatura de $800^{\circ} \mathrm{C}$, enquanto que He et al. (1996) chegaram a valores interessantes, com amostras calcinadas à $730^{\circ} \mathrm{C}$.

Esses resultados sugerem a viabilidade técnica do uso de materiais não somente cauliníticos para aproveitamento como pozolana, desde que termicamente adequados. Notou-se que, desses materiais, as argilas essencialmente illíticas e/ou interestratificados foram submetidas à temperaturas de ativação mais elevadas para a obtenção de resultados plenamente satisfatórios. 


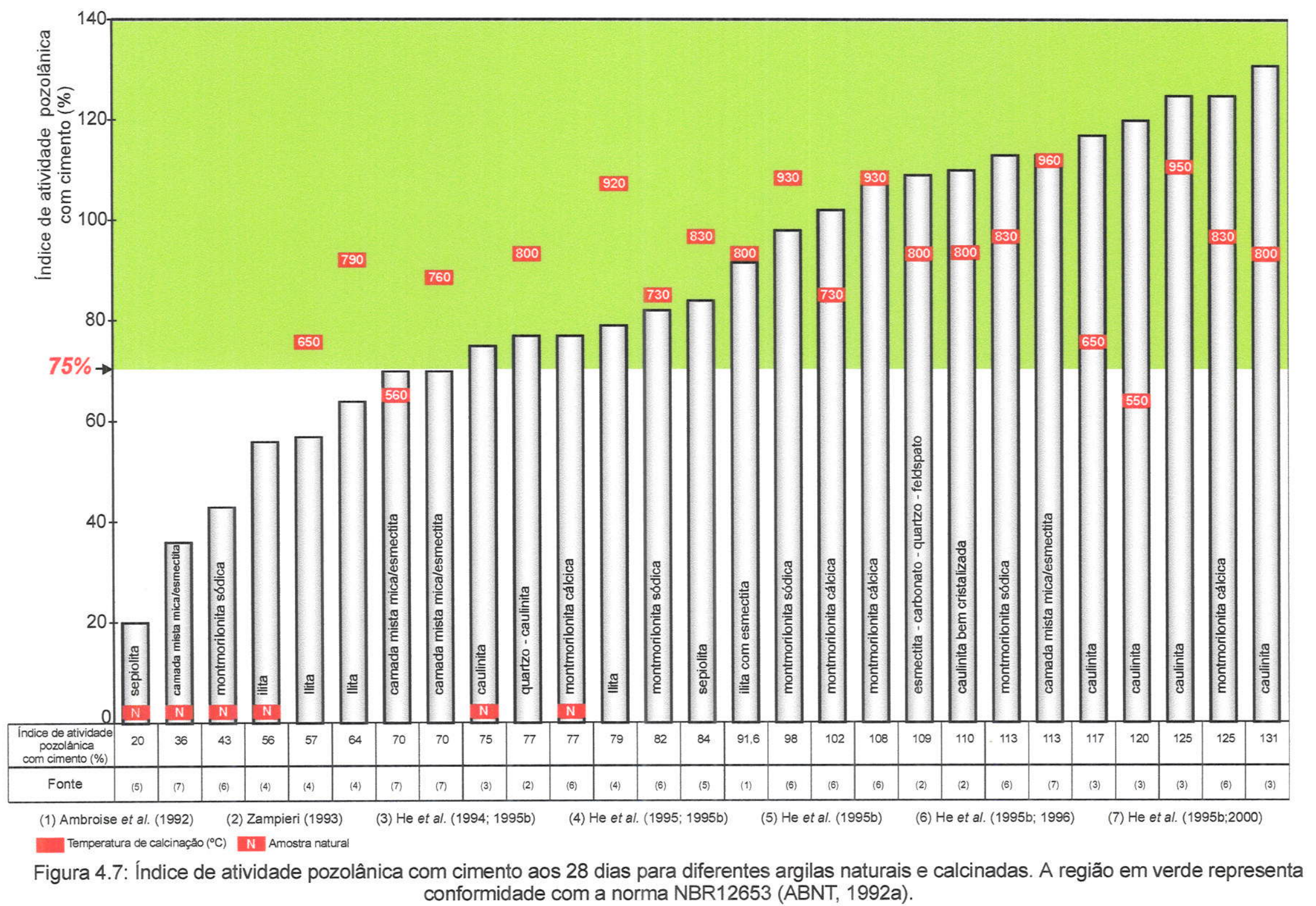




\section{CAPÍTULO V - MATERIAIS E MÉTODOS}

O trabalho foi realizado em etapas de escritório, campo e de laboratório.

\section{LEVANTAMENTO BIBLIOGRÁFICO}

O levantamento bibliográfico contemplou assuntos relacionados aos procedimentos empregados na caracterização tecnológica e à aplicabilidade industrial de matériasprimas argilosas, principalmente esmectíticas. Os capítulos II, III e IV resultaram da compilação de dados e revisão bibliográfica obtidas na literatura.

\section{ATIVIDADES DE CAMPO}

Buscou-se caracterizar o distrito areieiro do Bairro do Taboão sob os aspectos geológicos, características dos depósitos, procedimentos de lavra, etc., através de visitas às minerações e registros fotográficos. Desse agrupamento mineiro, a empresa Cessi Materiais para Construção Ltda. (Mineração Cessi) foi definida para estudo de caso, por ter se mostrado favorável à colaboração em atividades de campo e na cessão de dados.

Constaram dos trabalhos de campo na Mineração, o acompanhamento do processo produtivo - da extração ao despacho da areia beneficiada, assim como um mapeamento expedito das frentes de lavra a fim de se identificar os litotipos presentes. Foi também realizada a amostragem de níveis lamíticos de diferentes porções das frentes de lavra, respeitando-se a representatividade lateral e vertical.

A amostragem foi executada em 19 canais verticais- C1 a C19 - com cerca de $20 \mathrm{~cm}$ de largura por $10 \mathrm{~cm}$ de profundidade, ao longo da espessura do corpo (Figura 5.1). Em geral, a cada metro foram coletados cerca de $6 \mathrm{~kg}$, totalizando 44 amostras, cujas descrições encontram-se no Anexo 1. 


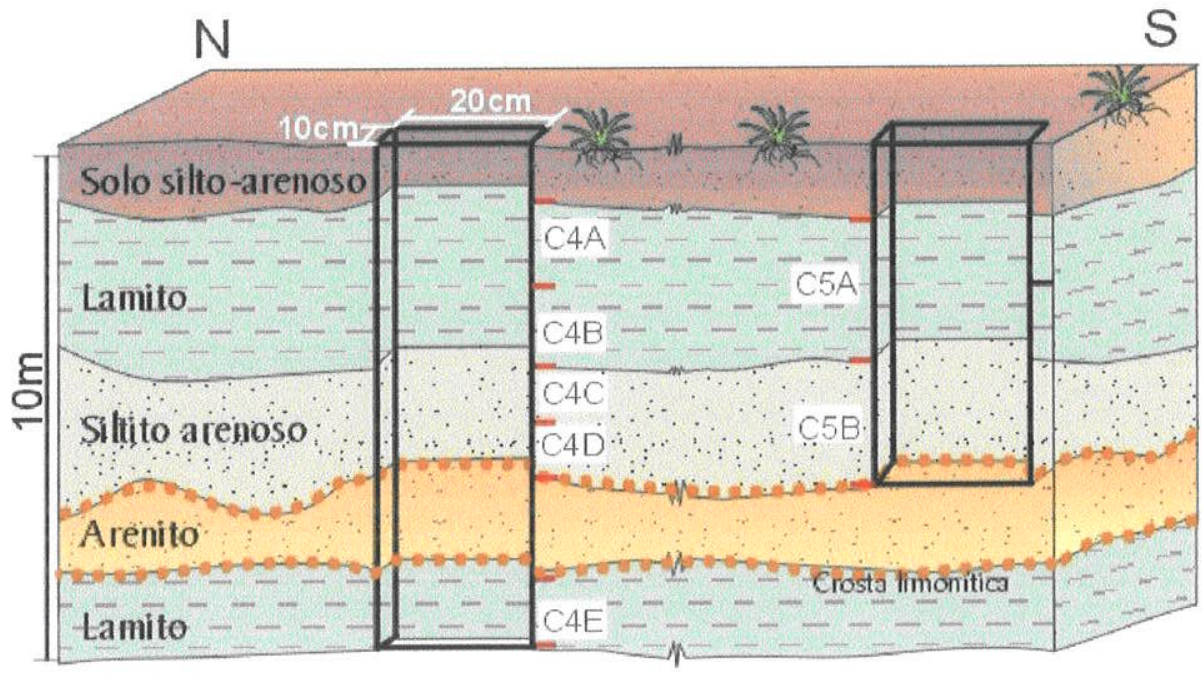

Figura 5.1: Esquema de amostragem por canal.

\section{CARACTERIZAÇÃO TECNOLÓGICA}

Segundo LCT (2000), a caracterização tecnológica é o estudo das propriedades físicas, químicas e físico-químicas de matérias-primas minerais face ao processo de beneficiamento ou uso final. Consiste no conhecimento da natureza e propriedades dos constituintes minerais através de métodos e instrumentos analíticos, visando a aplicabilidade nos processos de concentração ou mesmo no uso final, sendo norteada pelas especificações do segmento da indústria a que se destina o bem mineral.

A caracterização tecnológica visou definir a assembléia mineralógica, composição química total, capacidade de troca catiônica, distribuição do tamanho de partículas (granulometria), formas de associação mineral e transformações térmicas. Esses atributos nortearam a execução dos ensaios de aplicação, com vistas às indústrias cerâmica e de cimento.

Os ensaios inerentes à caracterização tecnológica e os específicos de aplicação foram realizados nos seguintes laboratórios: Laboratórios do Instituto de Geociências-USP; Laboratório de Caracterização Tecnológica do Departamento de Engenharia de Minas EPUSP; Laboratório de Matérias-Primas Particuladas e Sólidos Não-Metálicos - LMPSol do Departamento de Engenharia Metalúrgica e de Materiais - EPUSP; Laboratório de Mecânica de Solos do Departamento de Engenharia Civil-EPUSP e Laboratório da Associação Brasileira de Cimento Portland. 


\subsection{Seleção e preparação de amostras}

Do total das 44 amostras coletadas, foram selecionadas 17 , utilizando como critério as similaridades observadas em descrição macroscópica e a disposição espacial, com vistas a manter a representatividade do universo amostral.

As amostras foram secas ao ar livre e em estufa à $50^{\circ} \mathrm{C}$ durante $48 \mathrm{~h}$, sendo depois submetidas a redução granulométrica abaixo de 10-20 mm em britador de mandíbulas (Furlan - Modelo BM-2010).

A cominuição em moinho tipo Setamil e a desagregação foram efetuadas conforme a necessidade do método analítico. A Figura 5.2 mostra o fluxograma de preparação de amostras com os parâmetros determinados e os respectivos métodos empregados.

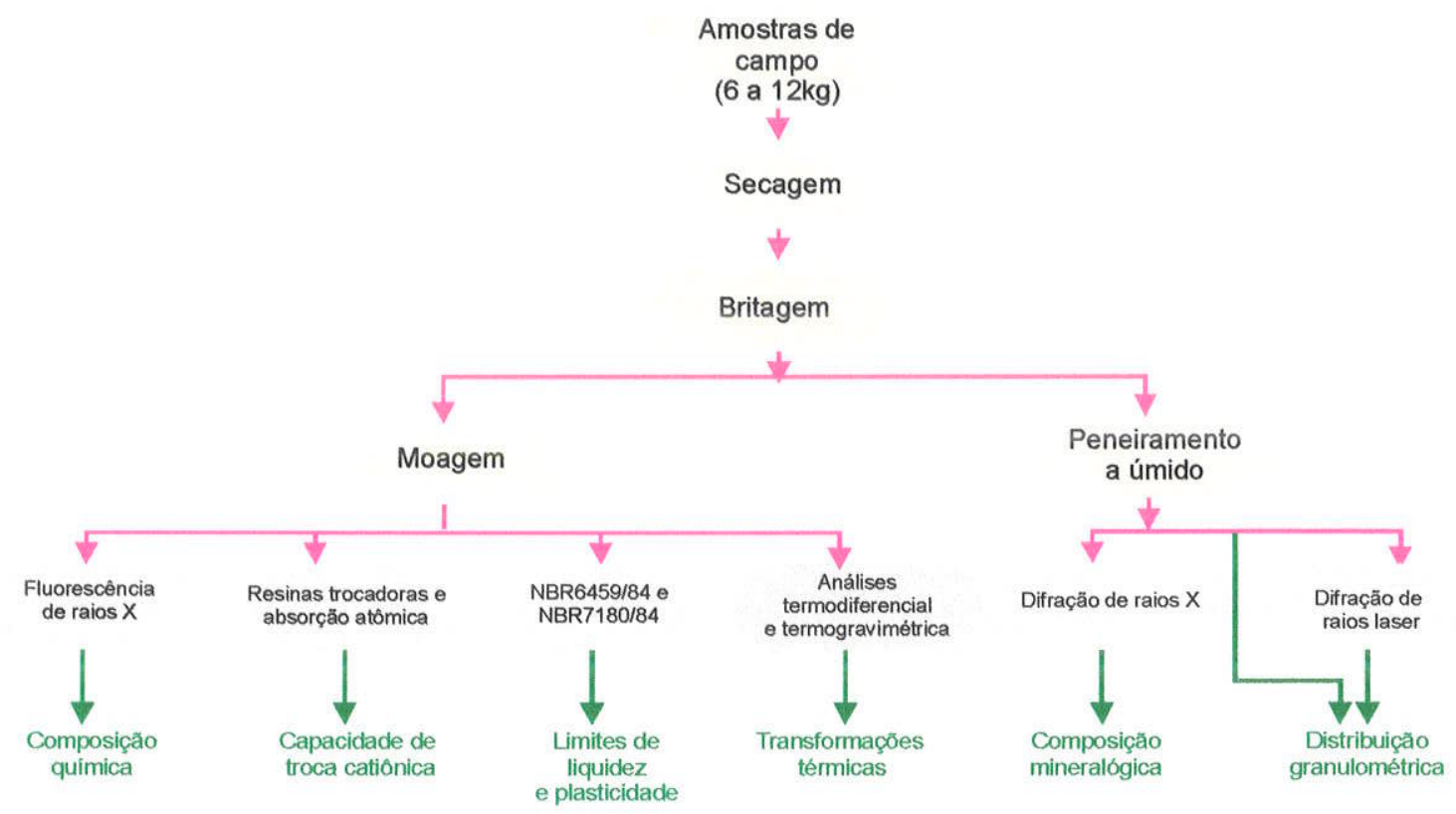

Figura 5.2: Fluxograma adotado para caracterização tecnológica.

\subsection{Distribuição granulométrica}

A distribuição do tamanho de partículas foi determinada por peneiramento a úmido em peneiras circulares de aberturas $500,177,150,106,75$ e $44 \mu \mathrm{m}$, seguida de análise por granulômetro de difração laser, via úmida, para o material $<44 \mu m$ (Analisador de Partículas Malvern $3600 E c)$, análises realizadas no Laboratório de Preparação de Amostras do Depto de Geologia Sedimentar e Ambiental - IGc-USP, e no Laboratório de Caracterização Tecnológica (LCT) - Dpto de Eng. Minas - EPUSP, respectivamente. 


\subsection{Composição Química}

Foram dosados os óxidos $\mathrm{SiO}_{2}, \mathrm{Al}_{2} \mathrm{O}_{3}, \mathrm{Fe}_{2} \mathrm{O}_{3}, \mathrm{TiO}_{2}, \mathrm{MgO}, \mathrm{CaO}, \mathrm{Na}_{2} \mathrm{O}, \mathrm{K} 2 \mathrm{O}, \mathrm{MnO}$ e $\mathrm{P}_{2} \mathrm{O}_{5}$ para amostras totais, em pastilha fundida com tetraborato de lítio. Utilizou-se o Espectrômetro de Fluorescência de Raios X (Modelo PW2400 da Philips), do Departamento de Mineralogia e Geotectônica - IGc-USP.

\subsection{Identificação Mineralógica}

A determinação da assembléia mineralógica de amostras naturais, assim como de compostos neoformados em processos cerâmicos e cimentíceos, foi realizada por difração de raios $X$. Foram aplicados diferentes métodos de preparação de amostras, adequados de acordo com o tipo de material analisado: lâmina de vidro, para frações finas $(<44 \mu \mathrm{m}$ e $-2 \mu \mathrm{m})$, método do pó prensado para amostras totais, fragmentos de corpos-de-prova de ensaios cerâmicos e de ensaios de pozolanicidade com cal. Foram utilizados os Difratômetro de Raios X Philips e Siemens (D5000), dos Laboratórios LCT -EPUSP e do Departamento de Mineralogia e Geotectônica - IGc-USP, respectivamente.

As condições de operação para ambos os equipamentos foram:

- radiação $\mathrm{CuK} \alpha$;

- passo de $0,02^{\circ} 2 \theta$ com tempo de contagem de 0,5 s para amostras $<44 \mu \mathrm{m}$, obtidas por peneiramento;

- passo de $0,05^{\circ} 2 \theta$ com tempo de contagem de $1 \mathrm{~s}$ para as demais análises;

- leitura de intervalo de ângulo de 2,5 a $70^{\circ} 2 \theta$ para amostras sem tratamento e 2,5 a $15^{\circ} 2 \theta$, para amostras glicoladas e aquecidas.

Os difratogramas obtidos foram interpretados com o programa EVA MFC Appplication versão 2.2.0.0/1996-1997, utilizando fichas de identificação do Joint Commitee on Powder Diffactin Standards (JCPDS). A editoração dos gráficos foi realizada nos programas Winfit Versão Beta Release 1.2.1 (Stefan Krumm, Geologisches Institut Erlangen, Schlossgarten 5, D-91054 Erlangen, 1997) e Corel Draw $®$.

$O$ estudo detalhado dos argilominerais foi realizado por difratometria de raios $X$ nas frações $<2 \mu \mathrm{m}$, separadas pelo método da pipetagem (Suguio, 1973).

A Figura 5.3 traz o fluxograma de preparação de amostras e o método empregado para a obtenção de difratograma de amostras naturais. 


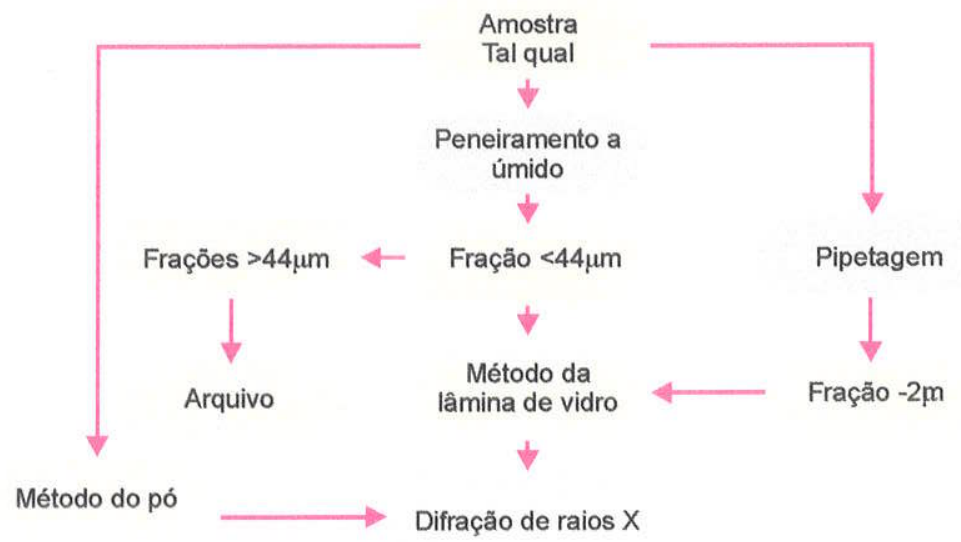

Figura 5.3: Fluxograma dos métodos empregados para as análises por difração de raios $X$ de amostras naturais.

Foram executadas trocas catiônicas, tratamentos térmicos e solvatações (glicerol e etilenoglicol) para a diferenciação das espécies de argilominerais expansivos da fração $<2 \mu \mathrm{m}$ (Tabela 5.1). A diferenciação foi diagnosticada através de alterações de posições das reflexões basais do pico (001).

Tabela 5.1: Tratamentos para identificação dos argilominerais (para fração $<2 \mu \mathrm{m}$ ), segundo Thorez (1976); Moore \& Reynolds (1997).

\begin{tabular}{|c|c|c|}
\hline $\begin{array}{l}\text { Reconhecimento, } \\
\text { identificação e } \\
\text { diferenciação entre } \\
\text { espécies }\end{array}$ & Saturação e solvatação & Reflexões diagnósticas \\
\hline $\begin{array}{l}\text { reconhecimento de } \\
\text { argilominerais expansivos }\end{array}$ & $\begin{array}{l}\text { solvatação com etilenoglicol, } \\
\text { seguido de aquecimento a } \\
550^{\circ} \mathrm{C} / 2 \mathrm{~h} \text {. }\end{array}$ & $\begin{array}{c}\text { Caulinita: } 7 \AA \text { - natural; } 7 \AA \text { - glicolado e } \\
\text { desaparecimento após aquecimento. } \\
\text { Esmectita: } 14,5 \AA \text { - natural; } 17,7 \AA \text { - glicolado e } \\
\text { colapso para } 10 \AA \text { após aquecimento. } \\
\text { Vermiculita: } 14,5 \AA \text { - natural; } 17,7 \AA \text { - glicolado e } \\
\text { colapso para } 10 \AA \text { após aquecimento. } \\
\text { Clorita: } 14,2 \AA \text { - natural; } 14,2 \AA \text { - glicolado e } \\
\text { colapso para } 14,2 \AA \text { após aquecimento. }\end{array}$ \\
\hline $\begin{array}{l}\text { beidellita, montmorillonita e } \\
\text { vermiculita }\end{array}$ & $\begin{array}{l}\text { saturação com cátion } \mathrm{Mg}^{+2} \text {, } \\
\text { seguido solvatação com } \\
\text { glicerol }\end{array}$ & $\begin{array}{c}\text { beidellita - sem expansão }(\sim 14 \AA) \\
\text { montmorillonita - expande de 14-15 para 17- } \\
18 \AA \\
\text { vermiculita - sem expansão }(\sim 14 \AA)\end{array}$ \\
\hline $\begin{array}{l}\text { esmectitas dioctaédricas e } \\
\text { esmectitas trioctaédricas }\end{array}$ & - & $\begin{array}{c}\text { dioctaédricas: pico }(006)=1,49-1,52 \\
\text { trioctaédricas: } 1,53-1,54\end{array}$ \\
\hline montmorillonita e beidellita & $\begin{array}{l}\text { teste de Greene-Kelly: } \\
\text { saturação com } \mathrm{Li}^{+} \text {mais } \\
\text { aquecimento a } 300^{\circ} \mathrm{C} / 2 \mathrm{~h} \text {, } \\
\text { seguido de solvatação com } \\
\text { etilenoglicol }\end{array}$ & $\begin{array}{c}\text { montmorilonita - sem expansão } \\
\text { beidellita - expansão para } 17-18 \AA \text {. }\end{array}$ \\
\hline montmorilonita e beidellita & saturação com K ${ }^{+}$ & $\begin{array}{c}\text { montmorillonita }-12,4 \AA \\
\text { beidellita }-10,1 \AA\end{array}$ \\
\hline
\end{tabular}

Foram também realizadas análises difratométricas para fragmentos de produtos de queima: de corpos-de-prova cerâmicos, de lamitos calcinados a 600 e $850^{\circ} \mathrm{C}$ e dos corpos de prova de ensaios pozolânicos com cal. As Figuras 5.4a e b apresentam os fluxogramas dos procedimentos adotados. 


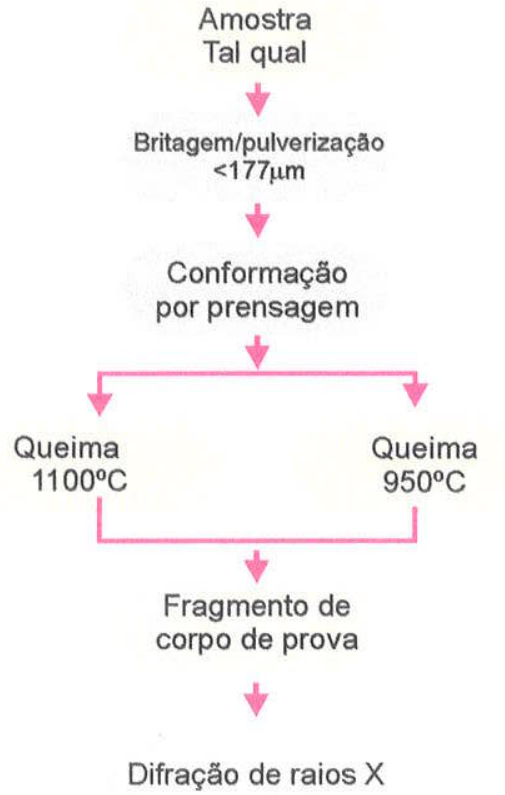

(a)

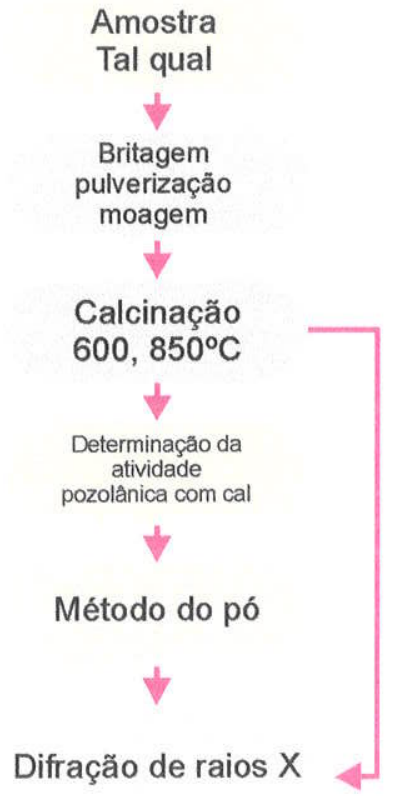

(b)

Figura 5.4: Fluxogramas de preparação de amostras para difração de raios $\mathrm{X}$ : (a) ensaios cerâmicos e (b) pozolanicidade.

\subsection{Determinação dos Cátions Trocáveis}

Foram dosados os cátions trocáveis $\mathrm{Na}, \mathrm{K}, \mathrm{Ca}, \mathrm{Mg}, \mathrm{H}$, e $\mathrm{Al}$, cuja somatória resultou na Capacidade de Troca Catiônica (CTC calculada). Essas determinações foram realizadas no Laboratório de Análise Química de Solo e Planta da UFSCar (Araras - SP) do Centro de Ciências Agrárias do Departamento de Recursos Naturais e Proteção AmbientalUFSCar, segundo métodos analíticos a úmido e instrumentais próprios. Os procedimentos analíticos foram:

- $\mathrm{Al}$ - por titulação com solução padrão de $\mathrm{NaOH}$;

- $\mathrm{H}^{+}$trocável -pela diferença entre o pH da amostra em solução de $\mathrm{CaCl}_{2}$ e da mesma com adição de solução tampão de sais neutros;

- Cálcio e magnésio -por espectrofotometria de absorção atômica após troca iônica do cálcio e magnésio da amostra pelo potássio em solução de $\mathrm{KCl} 1 \mathrm{~N}$;

- Sódio -por espectrofotometria de chama após troca com $\mathrm{H}^{+}$de solução de ácido clorídrico $0,1 \mathrm{~N}$;

- Potássio -por espectrofotometria de chama após troca com resina trocadora de cátions saturada de sódio em solução. 


\subsection{Análises Térmica Diferencial e Termogravimétrica}

Foram realizadas 4 análises termodiferenciais (ATD) e termogravimétricas (ATG) simultâneas, com o equipamento Simultaneous DTA-TGA (Modelo SDT 2960/TA Instruments), no Laboratório de Análises Mineralógicas do Depto de Geologia Sedimentar e Ambiental -IGc-USP.

As condições de análise adotadas foram: $20 \mathrm{mg}$ de amostra pulverizada e seca $a 0^{\circ} \mathrm{C}$, taxa de aquecimento de $10^{\circ} \mathrm{C} / \mathrm{min}$., intervalo de medição de $25^{\circ} \mathrm{C}$ a $1250^{\circ} \mathrm{C}$ e padrão de alumina. $\mathrm{O}$ aquecimento foi realizado em cadinho de alumina sob atmosfera dinâmica de nitrogênio.

\subsection{Microscopia Eletrônica de Varredura}

As amostras naturais foram analisadas na forma tal qual e também nas frações $<2 \mu \mathrm{m}$.

Buscou-se observar as fases geradas nos corpos-demprova queimados a $950^{\circ}$ e $1100^{\circ} \mathrm{C}$ obtidos nos ensaios cerâmicos, e também o produto da reação entre a pozolana e a cal.

Fó utilizado o microscópio eletrônico de varredura LEO (Modelo Stereoscan 440) acoplado a espectrômetro de dispersão de energia (EDS), do Laboratório de Caracterização Tecnológica do Departamento de Engenharia de Minas - EPUSP.

\section{ENSAIOS DE APLICAÇÃO}

Os resultados obtidos na caracterização tecnológica foram utilizados na seleção e/ou agrupamento das amostras para a realização dos ensaios específicos. As amostras pertencentes ao mesmo pacote sedimentar passaram a compor uma única amostra (C11A a C11F = C11; C19AB e C19DC = C19), com base na similaridade observada. Dessa forma, 9 amostras foram submetidas aos ensaios cerâmicos, compreendendo de lamitos a siltitos arenosos. Para os ensaios de pozolanicidade foram selecionadas 3 amostras de lamito e 1 amostra de lamito arenoso. 


\subsection{Ensaios Cerâmicos}

Foram efetuados ensaios cerâmicos expeditos para uma pré-qualificação para dois segmentos: a cerâmica estrutural e de revestimento, diferenciados pelas temperaturas de queima 950 e $1100^{\circ} \mathrm{C}$, respectivamente.

Os ensaios cerâmicos foram realizados exclusivamente em corpos-de-prova confeccionados por prensagem, por essa razão buscou-se complementar a caracterização cerâmica dos materiais de estudo com determinações dos limites de liquidez/plasticidade e indice de plasticidade, visando obter informações para a caracterização de matérias-primas conformadas por extrusão (cerâmica estrutural).

\subsubsection{Determinação dos Limites de Liquidez e Plasticidade}

As medidas dos limites de liquidez e plasticidade são parâmetros importantes na cerâmica, principalmente para processos de conformação que requerem grande volume de água, como ocorre na fabricação de cerâmica estrutural, louças domésticas e sanitárias.

A preparação das amostras foi realizada segundo recomendações da NBR 6457/86 (ABNT, 1986), e os limites determinados segundo as normas NBR6459/84 Determinação do Limite de Liquidez em Solo (ABNT, 1984a) e NBR7180/84 Determinação do Limite de Plasticidade em Solo (ABNT, 1984b). Os ensaios foram realizados por técnicos do Laboratório de Mecânica dos Solos do Departamento de Engenharia Civil da Escola Politécnica da USP.

\subsubsection{Preparação de corpos-de-prova.}

Foram adotados os procedimentos de rotina utilizados no Laboratório de Matérias-Primas Particuladas e Sólidos Não-Metálicos - LMPSol do Depto de Engenharia Metalúrgica e Materiais -EPUSP, que se basearam em métodos adaptados de Souza Santos (1989).

A preparação inicioumse com a pulverização das amostras secas em moinho de anéis vibratórios (tipo Setamil). Com os materiais reduzidos à granulação $<177 \mu \mathrm{m}$ foram prensados corpos-de-prova de $20 \times 60 \times 5 \mathrm{~mm}$ em moldes de aço (prensa hidráulica - Marca EVA), utilizando-se 25MPa de carga. Para cada amostra foram confeccionados cerca de 30 corpos-de-prova com aproximadamente $9,5 \mathrm{~g}$ e umidade de $5 \%$, aproximadamente. 


\subsubsection{Ensaios em corpos-de-prova}

Após a prensagem, os corpos-de-prova foram secos em estufa à $110^{\circ} \mathrm{C}$ durante $24 \mathrm{~h}$, e divididos em 3 subgrupos, um destinado aos ensaios físicos a seco, e os demais para a queima nas temperaturas de 950 e $1100^{\circ} \mathrm{C}$. A queima foi realizada em forno elétrico (Marca EDG -Modelo 1800), com taxa de aquecimento de $3^{\circ} \mathrm{C} / \mathrm{min}$, patamar de temperatura de 3 h e resfriamento natural.

Para os corpos-de-prova secos e queimados foram medidas as massas e as dimensões para a determinação da retração linear de secagem/queima.

Para o ensaio de absorção de água, procedeu-se conforme recomendações da NBR 13818/97 (ABNT, 1997), partindo-se de valores de massa saturada em água (ms). Foi também medida a massa imersa (mi), em balança hidrostática, para a determinação dos parâmetros de massa específica aparente (MEA) e porosidade aparente (PA) (Tabela 5.2).

A resistência mecânica (módulo de ruptura à flexão - MRF) foi determinada através do ensaio de rompimento dos corpos-de-prova, na máquina universal de ensaios (Marca Versat, Modelo 500), utilizando-se a velocidade de avanço de $0,01 \mathrm{~mm} / \mathrm{s}$. 
Tabela 5.2: Fórmulas para determinação dos parâmetros físicos dos corpos-de-prova.

\begin{tabular}{|c|c|c|c|}
\hline & Parâmetro & Fórmula & Onde: \\
\hline \multirow{3}{*}{ 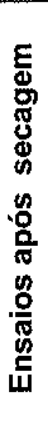 } & $\begin{array}{l}\text { umidade de } \\
\text { prensagem }\end{array}$ & $\mathrm{H}=\frac{\mathrm{Mu}-\mathrm{Ms}}{\mathrm{Mu}} .100$ & $\begin{array}{c}H=\text { umidade }(\%) \\
M u=\text { massa inicial com umidade }(\mathrm{g}) \\
\mathrm{Ms}=\text { massa final após secagem }(\mathrm{g})\end{array}$ \\
\hline & $\begin{array}{l}\text { retração de } \\
\text { secagem }\end{array}$ & $R S=\frac{L u-L S}{L u} .100$ & $\begin{array}{c}\text { RS = retração linear de secagem }(\%) \\
\text { Lu }=\text { comprimento inicial com umidade }(\mathrm{mm}) \\
\mathrm{Ls}=\text { comprimento final após secagem }(\mathrm{mm})\end{array}$ \\
\hline & $\begin{array}{l}\text { resistência } \\
\text { mecânica à } \\
\text { flexão }\end{array}$ & $M R F=\frac{3 F \cdot L}{2 b \cdot e_{\min }^{2}}$ & $\begin{array}{c}\text { MRF = módulo de resistência à flexão (MPa) } \\
F=\text { força de ruptura }(\mathrm{N}) \\
\begin{aligned} \mathrm{L}=\text { distância entre as barras de apoio }(\mathrm{mm})=4 \mathrm{~mm} \\
\mathrm{~b}=\text { largura do corpo-de-prova ao longo da ruptura } \\
\text { após o ensaio }(\mathrm{mm}) \\
\mathrm{e}=\text { espessura }(\mathrm{mm})\end{aligned}\end{array}$ \\
\hline \multirow{6}{*}{ 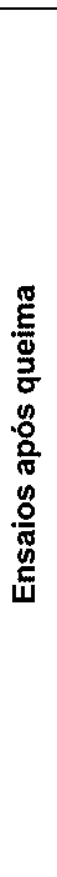 } & $\begin{array}{l}\text { retração de } \\
\text { queima }\end{array}$ & $R Q=\frac{L s-L q}{L s} .100$ & $\begin{array}{c}\mathrm{RQ}=\text { retração linear de queima }(\%) \\
\mathrm{Ls}=\text { comprimento após secagem }(\mathrm{mm}) \\
\mathrm{Lq}=\text { comprimento após queima }(\mathrm{mm})\end{array}$ \\
\hline & $\begin{array}{l}\text { resistência } \\
\text { mecânica à } \\
\text { flexão }\end{array}$ & $M R F=\frac{3 F \cdot L}{2 b \cdot e_{\min }^{2}}$ & $\begin{array}{c}\text { MRF }=\text { módulo de resistência à flexão (MPa) } \\
F=\text { força de ruptura }(\mathrm{N}) \\
\mathrm{L}=\text { distância entre as barras de apoio }(\mathrm{mm})=4 \mathrm{~mm} \\
\mathrm{~b}=\text { largura do corpo-de-prova ao longo da ruptura } \\
\text { após o ensaio }(\mathrm{mm}) \\
\mathrm{e}=\text { espessura }(\mathrm{mm})\end{array}$ \\
\hline & $\begin{array}{l}\text { absorção de } \\
\text { água }\end{array}$ & $\mathrm{AA}=\frac{\mathrm{mu}-\mathrm{ms}}{\mathrm{ms}} .100$ & $\begin{array}{c}\mathrm{AA}=\text { absorção de água }(\%) \\
\text { ms = massa seca }(\mathrm{g}) \\
\mathrm{mu}=\text { massa saturada em água }(\mathrm{g})\end{array}$ \\
\hline & $\begin{array}{l}\text { porosidade } \\
\text { aparente }\end{array}$ & $\mathrm{PA}=\frac{\mathrm{mu}-\mathrm{ms}}{\mathrm{mu}-\mathrm{mi}} \cdot 100$ & $\begin{array}{c}\mathrm{PA}=\text { porosidade aparente }(\%) \\
\mathrm{mu}=\text { massa saturada em água }(\mathrm{g}) \\
\mathrm{ms}=\text { massa seca }(\mathrm{g}) \\
\mathrm{mi}=\text { massa imersa em água }(\mathrm{g})\end{array}$ \\
\hline & $\begin{array}{c}\text { massa especifica } \\
\text { aparente }\end{array}$ & $\mathrm{MEA}=\frac{\mathrm{ms}}{\mathrm{mu}-\mathrm{mi}}$ & $\begin{array}{c}\text { MEA }=\text { massa especifica aparente }\left(\mathrm{g} / \mathrm{cm}^{3}\right) \\
m u=\text { massa saturada em água }(\mathrm{g}) \\
\text { ms }=\text { massa seca }(\mathrm{g}) \\
\mathrm{mi}=\text { massa imersa em água }(\mathrm{g}) \\
\mathrm{mu}-\mathrm{mi}=\text { volume aparente }\left(\mathrm{cm}^{3}\right)\end{array}$ \\
\hline & $\begin{array}{l}\text { massa especifica } \\
\text { aparente da } \\
\text { parte sólida }\end{array}$ & $\mathrm{MEA}_{\text {sólida }}=\frac{\mathrm{ms}}{\mathrm{ms}-\mathrm{mi}}$ & $\begin{array}{c}\text { MEA }_{\text {soblida }}= \\
\text { massa especifica aparente }\left(\mathrm{g} / \mathrm{cm}^{3}\right) \\
m i=\text { massa seca }(\mathrm{g}) \\
\mathrm{mi} \text { imersa em agua }(\mathrm{g})\end{array}$ \\
\hline
\end{tabular}

\subsection{Determinação de atividade pozolânica}

A determinação de atividade pozolânica com cal e cimento foi integralmente realizada pelos técnicos do Laboratório de Ensaios da Associação Brasileira de Cimento Portland (SP), cujos métodos empregados seguem estritamente as recomendações normativas da Associação Brasileira de Normas Técnicas (ABNT).

\subsubsection{Preparação das amostras}

As amostras naturais foram secas em estufa a $100^{\circ} \mathrm{C}$ durante $24 \mathrm{~h}$, sendo então britadas em britador de mandíbulas até granulometria menor que $0,84 \mathrm{~mm}$ e pulverizadas em moinho de bolas de porcelana até atingir um residuo inferior a $20 \%$ na peneira de $44 \mu \mathrm{m}$. Por último, foram feitas as calcinações nas temperaturas $550,600,700$ e $850^{\circ} \mathrm{C}$ durante $2 \mathrm{~h}$, em forno estático de alta temperatura. Após a preparação da amostra, determinaram- 
se a massa específica - NBR NM23/01 (ABNT, 2001), área específica - NBR NM76/98 (ABNT,1998); e o resíduo na peneira de 45 $\mu \mathrm{m}$ - NBR 12826/93 (ABNT, 1993).

\subsection{2 Índice de atividade pozolânica com cal - NBR 5751/92}

Foram preparadas argamassas compostas por uma parte (em massa) de hidróxido de cálcio, nove partes (em massa) de areia normal e mais uma quantidade de material pozolânico correspondente ao dobro do volume do hidróxido de cálcio, segundo a NBR 5751/92 (ABNT, 1992b). Foram moldados três corpos-de-prova cilíndricos de $50 \mathrm{~mm}$ de diâmetro por $100 \mathrm{~mm}$ de altura, utilizando-se as proporções de materiais indicadas na Tabela 5.3.

Tabela 5.3: Composição das argamassas de pozolana e cal

\begin{tabular}{|c|c|c|}
\hline Material & Massa $(\mathrm{g})$ & Onde \\
\hline Hidróxido de cálcio & 104 & $\begin{array}{c}\delta \text { poz }=\text { massa especifica do } \\
\text { material pozolânico (NBR } \\
6474) .\end{array}$ \\
\hline Areia normal & 234 de cada uma das quatro fraçóes \\
Material pozolânico & $2 \times \frac{\delta p o z}{\delta c a l} \times 104$ & $\begin{array}{c}\delta \text { cal }=\text { massa especifica da cal } \\
\text { hidratada (NBR 6474). }\end{array}$ \\
\hline
\end{tabular}

* definido pela NBR 7215/96.

O material pozolânico e o hidróxido de cálcio foram homogeneizados em recipiente fechado, durante 2 minutos, aproximadamente. A água de amassamento (quantidade de água para a mistura correspondente a um índice de consistência de $225 \pm 5 \mathrm{~mm}$ obtido no ensaio de abatimento - NBR 7215/96 - ABNT, 1996 ) foi adicionada à mistura na cuba de um misturador mecânico. A agitação da areia e o tempo de amassamento, as moldagem e desmoldagem, e o rompimento dos corpos-de-prova em ensaios de resistência à flexão, seguiram as recomendações da NBR 7215/96 (ABNT, 1996).

Durante os 7 dias de cura os corpos-de-prova foram mantidos vedados para garantir a umidade, sendo que, durante as primeiras $24 \pm 2 \mathrm{~h}$ os corpos-de-prova permaneceram à temperatura de $23 \pm 2^{\circ} \mathrm{C}$, durante as $144 \pm 2 \mathrm{~h}$ posteriores foram mantidos em temperatura de $55 \pm 2^{\circ} \mathrm{C}$ até $4 \pm 0,5 \mathrm{~h}$ antes do ensaio de ruptura à compressão, quando os corpos-de-prova passaram à temperatura de $23 \pm 2^{\circ} \mathrm{C}$, conforme a NBR $5751 / 92$ (ABNT, 1992a). 


\subsection{3 Índice de atividade pozolânica com cimento - NBR 5752/92}

Para a confecção dos corpos-de-prova, foram preparadas argamassas com dois traços diferentes: a Argamassa A, de referência, somente com cimento Portland e, a Argamassa B, com $35 \%$ do seu volume absoluto de cimento substituído por material pozolânico. Para cada tipo de argamassa, foram moldados três corpos-de-prova cilíndricos de $50 \times 100 \mathrm{~mm}$, sendo que as proporções de materiais utilizados constam da Tabela 5.4.

Tabela 5.4: Composição das argamassas com cimento

\begin{tabular}{|c|c|c|c|}
\hline \multirow{2}{*}{ Material } & \multicolumn{2}{|c|}{ Massa $(\mathrm{g})$} & \multirow{2}{*}{ Onde } \\
\hline & Argamassa A & Argamassa B & \\
\hline Cimento Portland & 912,0 & 202,8 & \multirow{4}{*}{$\begin{array}{l}A=\text { massas específicas do material } \\
\text { pozolânico e do cimento (NBR } 6474 \text { ) } \\
B=\text { quantidades de água (NBR } 7215 \text { ) }\end{array}$} \\
\hline Material pozolânico & - & $109,2 \times \frac{\delta p^{(A)}}{\delta c^{(A)}}$ & \\
\hline Areia normal & 936,0 & 936,0 & \\
\hline Água & $x(B)$ & $y(B)$ & \\
\hline
\end{tabular}

A moldagem e o rompimento dos corpos-de-prova nos ensaios de resistência à flexão, seguiram as recomendações da NBR 7215/96 (ABNT, 1996). A água requerida é expressa em porcentagem pela seguinte relação: Água requerida $=\frac{B}{A} \times 100(\%)$, onde: $B$ e $A$ = quantidade de água necessária para a obtenção de índices de consistência normais de $225 \pm 5 \mathrm{~mm}$ para as argamassas $B$ e $A$, respectivamente.

Após a moldagem, os corpos-de-prova cilíndricos foram colocados em câmara úmida à temperatura de $23 \pm 2^{\circ} \mathrm{C}$, durante $24 \pm 2 \mathrm{~h}$, com as faces superiores expostas ao ar úmido, mas protegidas de respingos de água. Após a desmoldagem, os corpos-de-prova foram armazenados em recipientes hermeticamente fechados e estanques, sob temperatura de $38 \pm 2^{\circ} \mathrm{C}$, durante 27 dias. Para o ensaio à compressão, os corpos-de-prova, ainda dentro dos recipientes fechados, foram resfriados ao ar até $23 \pm 2^{\circ} \mathrm{C}$ (NBR 5752/92 - ABNT, 1992C).

O cálculo do índice de atividade pozolânica com cimento Portland foi feito através da fórmula indicada na Tabela 5.5.

Tabela 5.5: Fórmula para a determinação do índice de atividade pozolânica

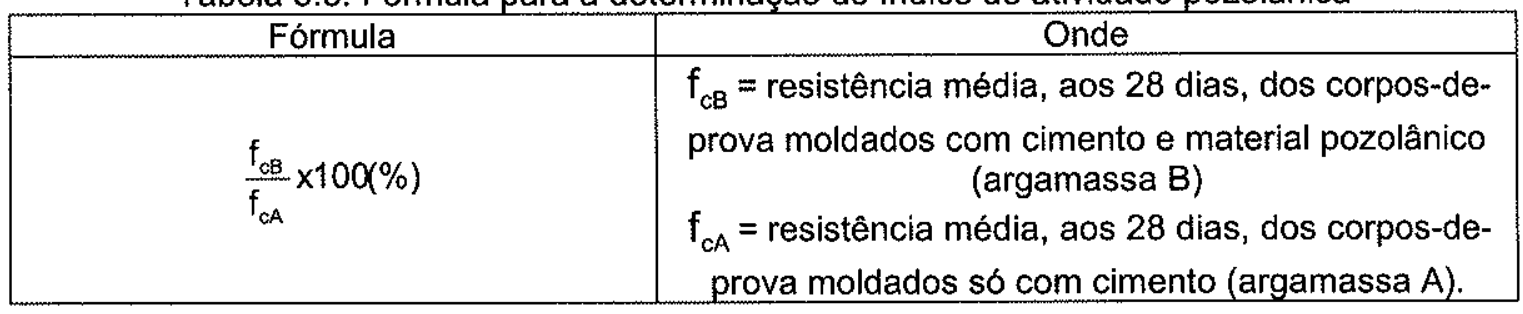




\section{CAPITTULO VI-RESULTADOS OBTIDOS NAS ATIVIDADES DE CAMPO E NA CARACTERIZAÇÃO TECNOLÓGICA}

\section{ATIVIDADES DE CAMPO}

Durante a execução dos trabalhos de campo foram visitadas 8 minerações de areia dentre as 14 existentes no Bairro do Taboão, cujos dados de localização, processos de beneficiamento, destinação de rejeitos e registros fotográficos são apresentados no Anexo I.

Somente três empresas extraem a areia de sedimentos da Formação São Paulo, o que lhes confere melhores recuperações e rendimentos, consequentemente menores volumes de estéril/rejeitos e resíduos finos gerados durante o processamento. As demais empresas, incluindo-se a Mineração Cessi, encontram-se sobre os depósitos sedimentares da Formação Resende, com suas intercalações métricas de lamitos e arenitos.

Visando avaliar a garantia do fornecimento do material em estudo, aspecto crítico do ponte de vista industrial, foi feita uma avaliação dos recursos minerais disponíveis. Para tanto foram adotados os parâmetros de lavra (produção, recuperação, profundidade e relação lamito/arenito) da Mineração Cessi nos anos de 2000 e 2001, considerando avanços de $70 \mathrm{~m}$ para a Cava 1 e $100 \mathrm{~m}$ para a Cava 2, para um período de 3 anos.

Com a projeção feita, verificou-se que nos próximos 3 anos serão removidos cerca de $860.000 \mathrm{~m}^{3}$ de material para extração de $546.000 \mathrm{~m}^{3}$ de areia (sem beneficiamento) e um volume de $314.000 \mathrm{~m}^{3}$ de material lamítico. A quantidade de lamito a ser mobilizada é bastante elevada, sendo que há limitação de áreas para deposição desse material.

A amostragem foi realizada exclusivamente em frentes de lavra da Mineração Cessi. Procurou-se coletar amostras dos níveis lamíticos e siltosos que tivessem espessura igual ou superior à $0,5 \mathrm{~m}$ (descrições no Anexo 2 ), considerado como limite operacional para uma possivel lavra seletiva.

A Figura 6.1 apresenta configuração da Mineração Cessi no primeiro semestre de 2000, e a Figura 6.2 mostra a seção esquemática $A^{\prime}-A$, e os pontos de amostragem. As Pranchas 6.1 e 6.2 apresentam aspectos gerais da Mineração Cessi, assim como detalhes dos locais de amostragem. 


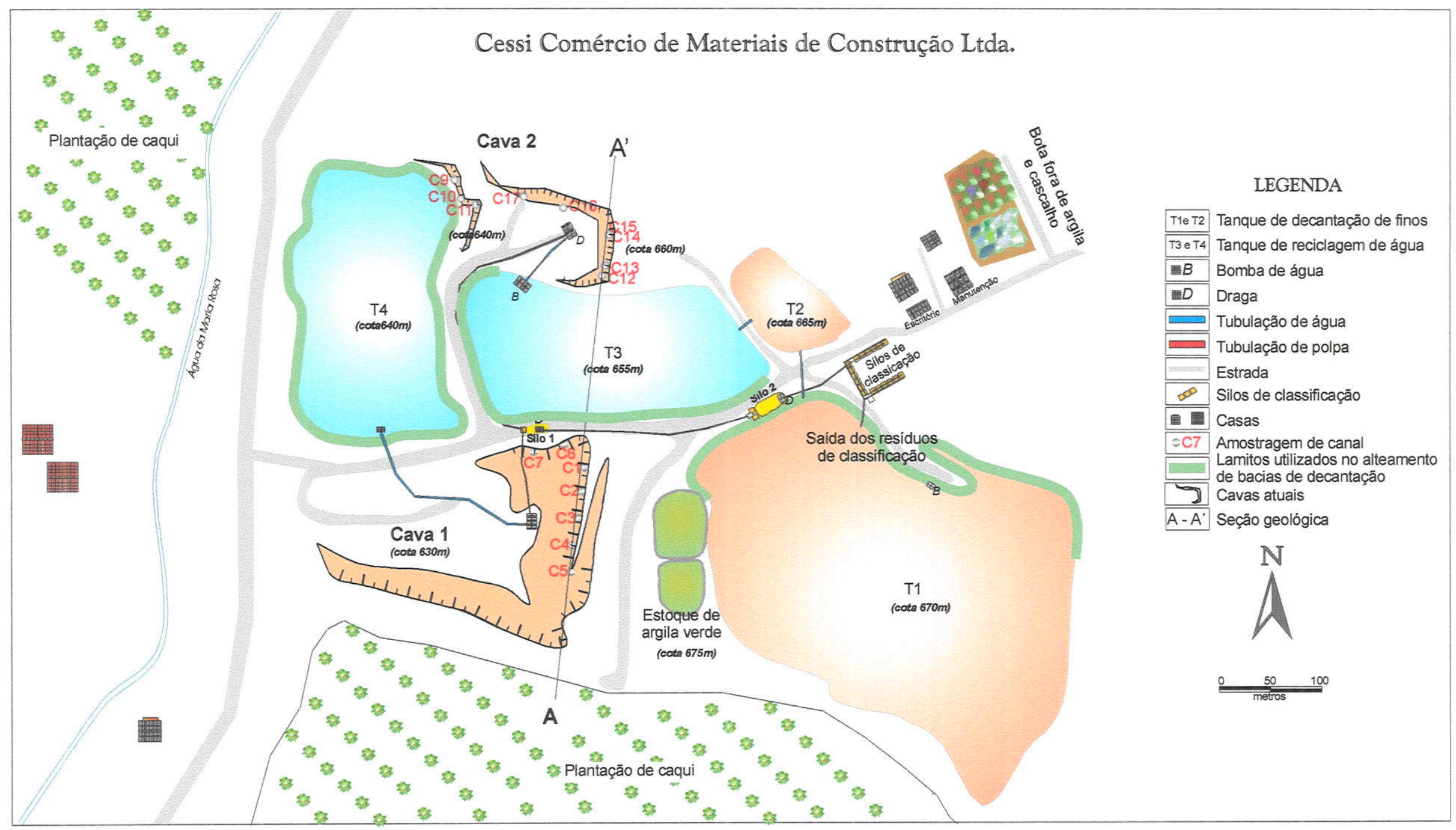

Figura 6.1: Planta esquemática da Mineração Cessi, Mogi das Cruzes (SP). 


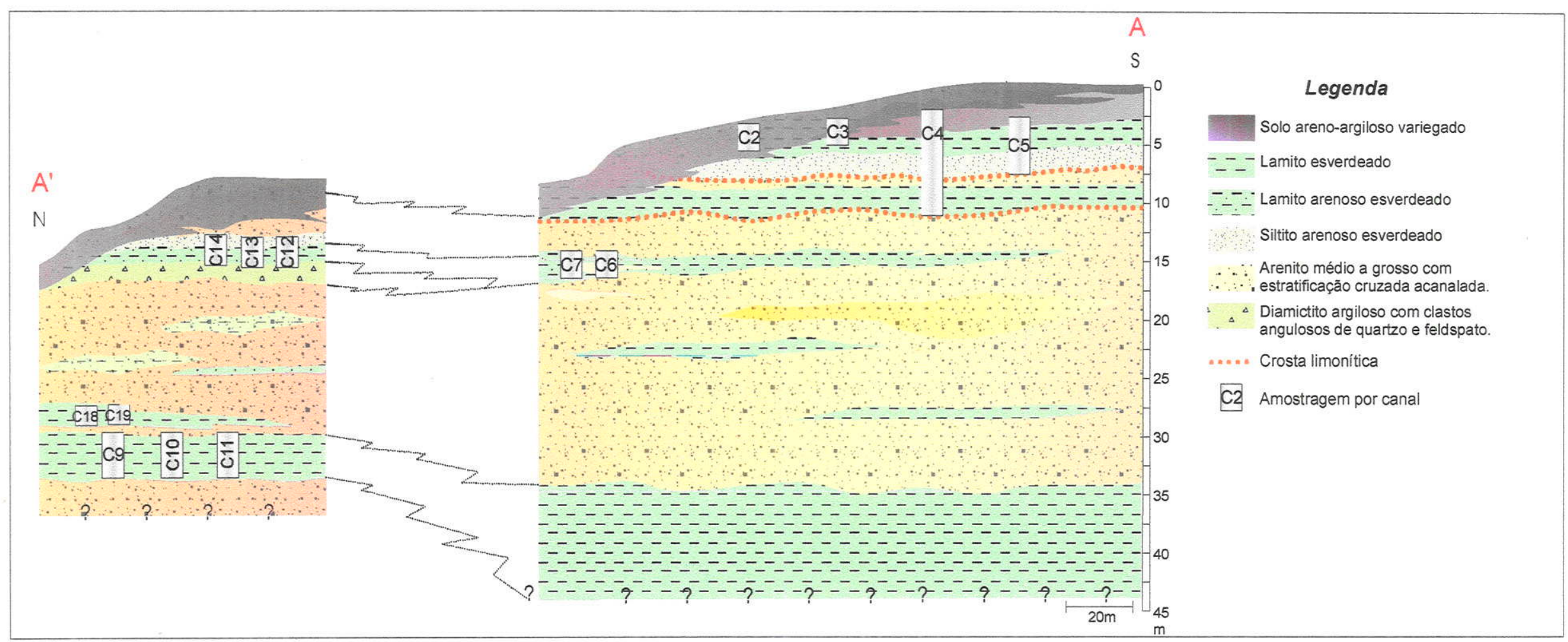

\begin{tabular}{|c|c|c|c|}
\hline Canal & Amostra & $\begin{array}{c}\text { Espessurat } \\
(m)\end{array}$ & Rocha \\
\hline $\mathrm{C2}$ & $\mathrm{C} 2 \mathrm{~S}$ & 0,80 & Lamito arenoso verde arroxeado \\
\hline C3 & $\mathrm{C} 3$ & 1,00 & Lamito arenoso variegado \\
\hline \multirow{6}{*}{ C4 } & C4A & 1,50 & Lamito verde com porçōes arroxeadas \\
\hline & $C 4 B$ & 1,50 & Lamito verde com porçôes arroxeadas \\
\hline & C4C & 0,90 & Siltito arenoso verde maciço \\
\hline & C4D & 0,90 & Siltito arenoso verde maciço \\
\hline & C4E & 1,40 & Lamito verde \\
\hline & C4E/2 & 1,40 & Lamito verde \\
\hline \multirow{2}{*}{ C5 } & C5A & 3,00 & Lamito verde com porçōes arroxeadas \\
\hline & C5B & 1,80 & Siltito arenoso verde maciço \\
\hline \multirow{3}{*}{ c6 } & $\cos$ & 0,80 & Lamito arenoso roxo \\
\hline & CEV & 1,40 & Lamito arenoso esverdeado a acastanhado \\
\hline & C6! & 0,30 & \\
\hline
\end{tabular}

\begin{tabular}{|c|c|c|c|}
\hline Canal & Amostra & 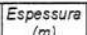 & Rocha \\
\hline C7 & $\mathrm{C7}$ & 3,35 & Lamito verde \\
\hline \multirow{4}{*}{ c9 } & C9A & 1,60 & Lamito verde \\
\hline & C9B & 1,40 & Lamito verde \\
\hline & $\operatorname{coc}$ & 1,20 & Lamito verde \\
\hline & C9D & 1,00 & Lamito interdigitado com lamito arenoso \\
\hline \multirow{6}{*}{ C10 } & C10A & 1,00 & Lamito verde \\
\hline & $\mathrm{C} 10 \mathrm{~B}$ & 0,30 & Lamito verde \\
\hline & $\mathrm{C} 10 \mathrm{C}$ & 1,00 & Lamito verde \\
\hline & $C 10 D$ & 0,80 & Lamito verde \\
\hline & C10E & 1,00 & Lamito verde \\
\hline & C10F & 0,70 & Lamito verde com porcōes arroxeadas \\
\hline
\end{tabular}

\begin{tabular}{|c|c|c|c|}
\hline Cana & Amostra & $\begin{array}{c}\text { Espessura } \\
(m)\end{array}$ & Rocha \\
\hline \multirow{6}{*}{ C11 } & C11A & 1,00 & Lamito verde \\
\hline & C11B & 1,00 & Lamito verde \\
\hline & C11C & 1,00 & Lamito verde \\
\hline & $\overline{C 11 D}$ & 1,00 & Lamito verde \\
\hline & C11E & 1,00 & Lamito verde a levemente marrom \\
\hline & C11F & 1,00 & Lamito levemente marrom esverdeada \\
\hline C12 & $\mathrm{C} 12$ & 1,20 & Siltito arenoso alaranjado \\
\hline \multirow{3}{*}{ C13 } & C13A & 1,20 & Siltito arenoso verde \\
\hline & C13B & 0,80 & Lamito verde, localmente acastanhado \\
\hline & $\mathrm{C} 13 \mathrm{C}$ & 1,30 & Diamictito com matriz argilose verde \\
\hline
\end{tabular}

\begin{tabular}{|c|c|c|c|}
\hline Cana & Amostra & $\begin{array}{c}\text { Espessura } \\
(m)\end{array}$ & Rocha \\
\hline \multirow{3}{*}{ C14 } & C14A & 1,10 & Siltito arenoso verde \\
\hline & C14B & 0,90 & Lamito verde \\
\hline & C14C & 1,50 & Diamictito com matriz argilosa verde \\
\hline $\mathrm{C} 15$ & C15 & 0,95 & Lamito verde \\
\hline $\mathrm{C} 16$ & C16 & 1,60 & Lamito arenoso \\
\hline \multirow{2}{*}{ C17 } & C17A & 1,40 & Lamito verde com porçઠేs arroxeadas \\
\hline & C17B & 1,20 & Diamictito com matriz argilosa \\
\hline C18 & C18A & 1,10 & Lamito verde \\
\hline \multirow{2}{*}{$C_{19}$} & CI9AB & 1,50 & Lamito verde \\
\hline & C19CD & 1,50 & Lamito verde \\
\hline
\end{tabular}

Figura 6.2: Seção geológica A'-A com a localização dos pontos de amostragem, e descrição simplificada dos intervalos amostrados. 

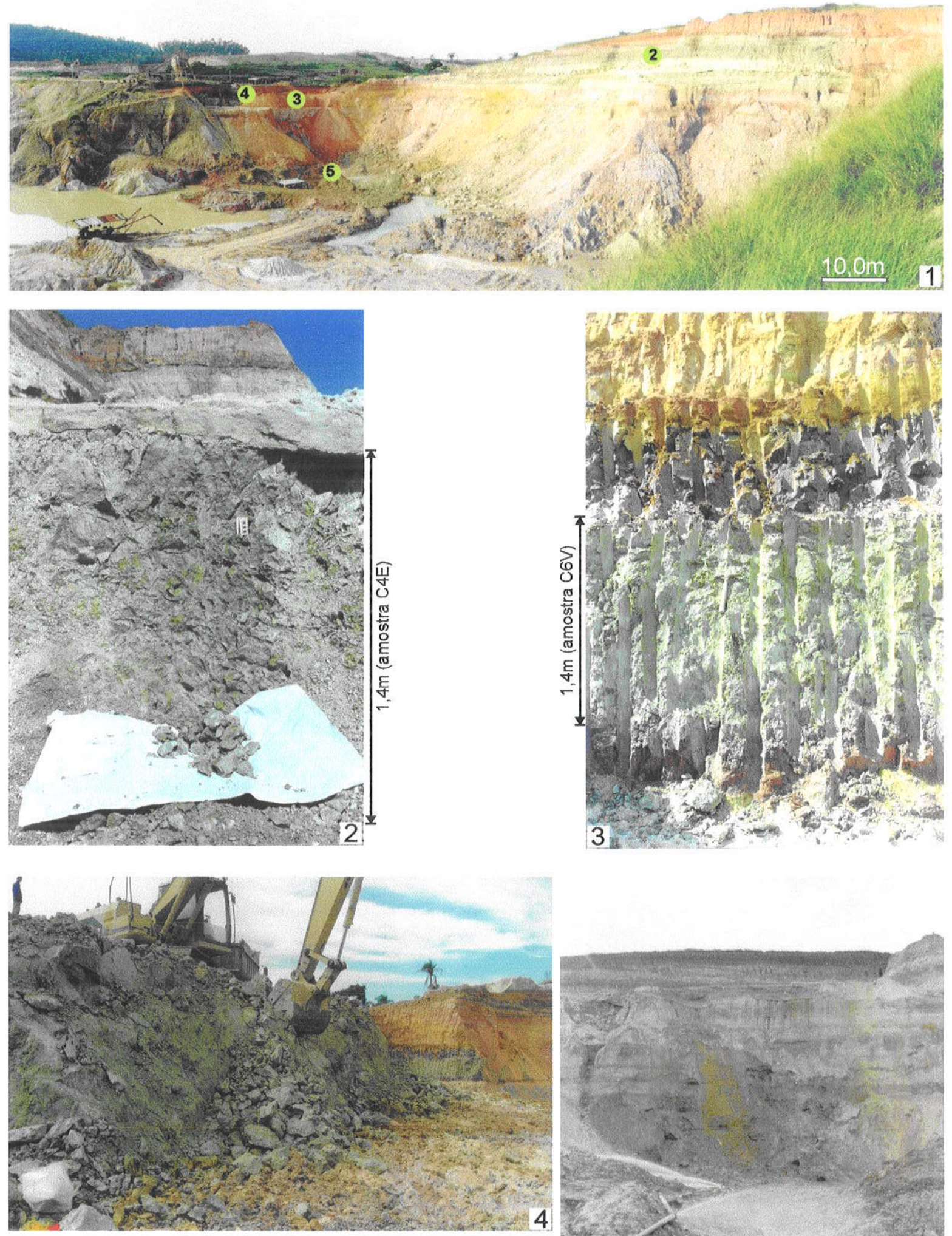

Prancha 6.1: Cava 1 da Mineração Cessi: (1) frente de lavra atual; (2) nível lamítico (amostra C5A); (3) nível lamítico arenoso (amostra C6V); (4) operação de decapeamento do nível lamítico arenoso e; (5) desmonte hidráulico.

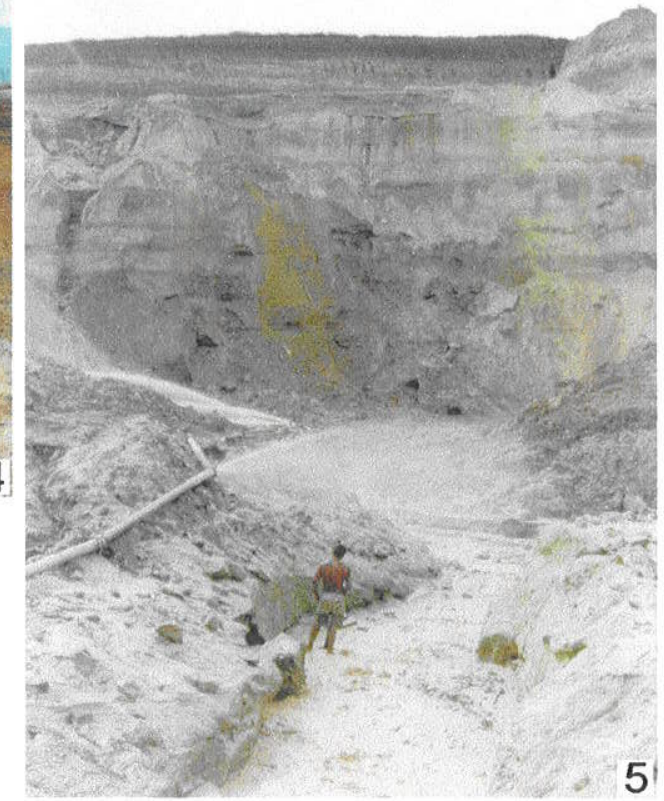



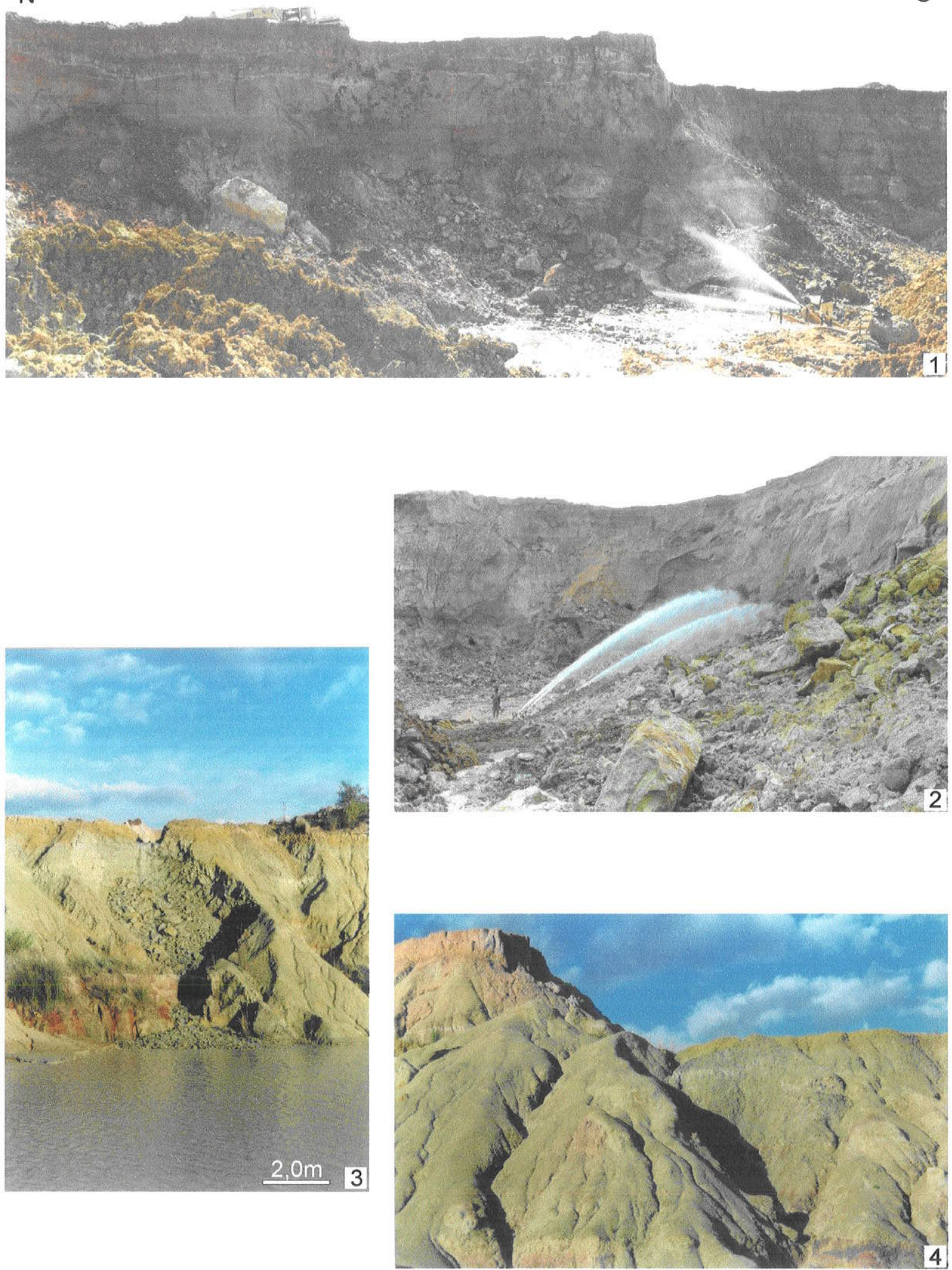

Prancha 6.2: Cava 2 da Mineração Cessi: (1) frente de lavra atual; (2) desmonte hidráulico; (3) e (4) nível de lamito presente na base da Cava 2 - pontos de amostragem (C9, 10 e 11) - espessura total do nível lamítico: $6 \mathrm{~m}$. 


\section{CARACTERIZAÇÃO TECNOLÓGICA}

Os ensaios de caracterização tecnológica consistiram em determinação das composições granulométricas, químicas e mineralógicas em amostras selecionadas, como sumariado na Tabela 6.1.

Tabela 6.1: Sumário das atividades de caracterização tecnológica e ensaios de aplicação.

\begin{tabular}{|c|c|c|c|c|c|c|c|c|c|c|c|}
\hline \multirow[b]{2}{*}{ Amostra } & \multirow[b]{2}{*}{ Rocha } & \multicolumn{7}{|c|}{ Caracteriza cáo tecnológlca } & \multicolumn{3}{|c|}{$\begin{array}{l}\text { Ensalos de } \\
\text { Aplicacaão }\end{array}$} \\
\hline & & 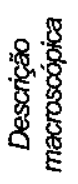 & 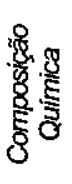 & 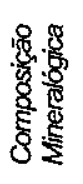 & 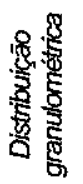 & 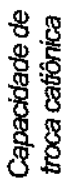 & $\begin{array}{l}\frac{8}{5} \\
\frac{8}{5} \\
\frac{5}{5}\end{array}$ & $\stackrel{0}{Q}$ & 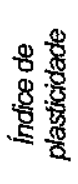 & 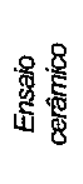 & 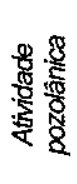 \\
\hline $\mathrm{C} 2 \mathrm{~S}$ & LA & $x$ & $x$ & $x$ & $x$ & $\mathrm{x}$ & $\mathrm{C} 2 \mathrm{~S}$ & & $x$ & $\mathrm{x}$ & \\
\hline $\mathrm{C} 3$ & LA & $x$ & & & & & & & & & \\
\hline $\mathrm{C} 4 \mathrm{~A}$ & $\mathrm{~L}$ & $x$ & $x$ & $x$ & $x$ & $x$ & C4A & & & $x$ & \\
\hline$\overline{C 4 B}$ & $\mathrm{~L}$ & $\bar{x}$ & $x$ & $x$ & $x$ & $x$ & $\mathrm{C} 4 \mathrm{~B}$ & & $\mathrm{x}$ & $\bar{x}$ & \\
\hline C4C & $\overline{S A}$ & $\bar{x}$ & & & & & & & & & \\
\hline C4D & SA & $x$ & & & & & & & & & \\
\hline $\mathrm{C} 4 \mathrm{E}$ & $L$ & $x$ & & & & & & & & & \\
\hline $\mathrm{C} 4 \mathrm{E} / 2$ & $\mathrm{~L}$ & $\mathrm{x}$ & & & & & & & & & \\
\hline C5A & $L$ & $\bar{x}$ & $x$ & $\mathrm{x}$ & $\mathrm{x}$ & $x$ & $\mathrm{C} 5 \mathrm{~A}$ & $x$ & & $x$ & $x$ \\
\hline C5B & $S A$ & $x$ & $x$ & $x$ & $x$ & $x$ & C5B & & $x$ & $x$ & \\
\hline C6S & $\overline{\mathrm{LA}}$ & $\frac{x}{x}$ & & & & & & & & & \\
\hline $\mathrm{C} 6 \mathrm{~V}$ & $\mathrm{LA}$ & $x$ & $x$ & $x$ & $x$ & $x$ & $\mathrm{C} 6 \mathrm{~V}$ & $x$ & $x$ & $x$ & $x$ \\
\hline C6! & LA & $x$ & & & & & & & & & \\
\hline $\mathrm{C7}$ & $L$ & $x$ & & & & & & & & & \\
\hline $\mathrm{C9A}$ & L & $\bar{x}$ & & & & & & & & & \\
\hline $\mathrm{CgB}$ & L & $x$ & & & & & & & & & \\
\hline C9C & $\mathrm{L}$ & $\bar{x}$ & & & & & & & & & \\
\hline C9D & $L$ & $x$ & & & & & & & & & \\
\hline C10A & $L$ & $x$ & & & & & & & & & \\
\hline $\mathrm{C} 10 \mathrm{~B}$ & $\mathrm{~L}$ & $x$ & & & & & & & & & \\
\hline $\mathrm{C} 10 \mathrm{C}$ & $L$ & $x$ & & & & & & & & & \\
\hline C10D & $\mathrm{L}$ & $\bar{x}$ & & & & & & & & & \\
\hline $\mathrm{C} 10 \mathrm{E}$ & $\mathrm{L}$ & $x$ & & & & & & & & & \\
\hline $\mathrm{C} 10 \mathrm{~F}$ & $L$ & $\bar{x}$ & & & & & & & & & \\
\hline C11A & $L$ & $x$ & $x$ & $x$ & $x$ & $x$ & & & & & \\
\hline C11B & $L$ & $x$ & $x$ & $x$ & $x$ & $x$ & & & & & \\
\hline C11C & $L$ & $x$ & $x$ & $x$ & $x$ & $x$ & C11 & $x$ & $x$ & $x$ & $x$ \\
\hline C11D & $L$ & $x$ & $x$ & $x$ & $x$ & $x$ & & $x$ & $x$ & & $x$ \\
\hline C11E & $\mathrm{L}$ & $x$ & $x$ & $x$ & $x$ & $x$ & & & & & \\
\hline C11F & $\bar{L}$ & $\bar{x}$ & $x$ & $\mathrm{x}$ & $x$ & $x$ & & & & & \\
\hline $\mathrm{C} 12$ & SA & $x$ & & & & & & & & & \\
\hline C13A & SA & $x$ & $x$ & $x$ & $x$ & $x$ & & & & & \\
\hline $\mathrm{C} 13 \mathrm{~B}$ & $L$ & $x$ & $x$ & $x$ & $x$ & $x$ & & & $x$ & $x$ & \\
\hline $\mathrm{C} 13 \mathrm{C}$ & D & $x$ & & & & & & & & & \\
\hline C14A & SA & $\bar{x}$ & & & & & & & & & \\
\hline C14B & $\mathrm{L}$ & $x$ & & & & & & & & & \\
\hline $\mathrm{C} 14 \mathrm{C}$ & D & $x$ & & & & & & & & & \\
\hline $\mathrm{C} 15$ & $\mathrm{~L}$ & $x$ & & & & & & & & & \\
\hline $\mathrm{C} 16$ & LA & $x$ & & & & & & & & & \\
\hline C17A & $L$ & $x$ & & & & & & & & & \\
\hline $\mathrm{C} 17 \mathrm{~B}$ & $\bar{D}$ & $x$ & & & & & & & & & \\
\hline C18A & $L$ & $x$ & $x$ & $x$ & $x$ & $x$ & C18 & & $x$ & & \\
\hline $\mathrm{C} 19 \mathrm{AB}$ & $\mathrm{L}$ & $x$ & $x$ & $x$ & $x$ & $x$ & C19 & $x$ & $x$ & $x$ & $x$ \\
\hline C19CD & $L$ & $x$ & $x$ & $x$ & $x$ & $x$ & 619 & $x$ & $x$ & $x$ & $x$ \\
\hline
\end{tabular}

L -lamito; LA - lamito arenoso; SA - siltito arenoso; D - diamictito 


\subsection{Distribuição granulométrica}

A classificação granulométrica das partículas, realizada por peneiramento a úmido conjugado com resultados do analisador a laser para frações $<44 \mu \mathrm{m}$, permitiu obter a distribuição granulométrica das 17 rochas sedimentares amostradas (Figura 6.4).

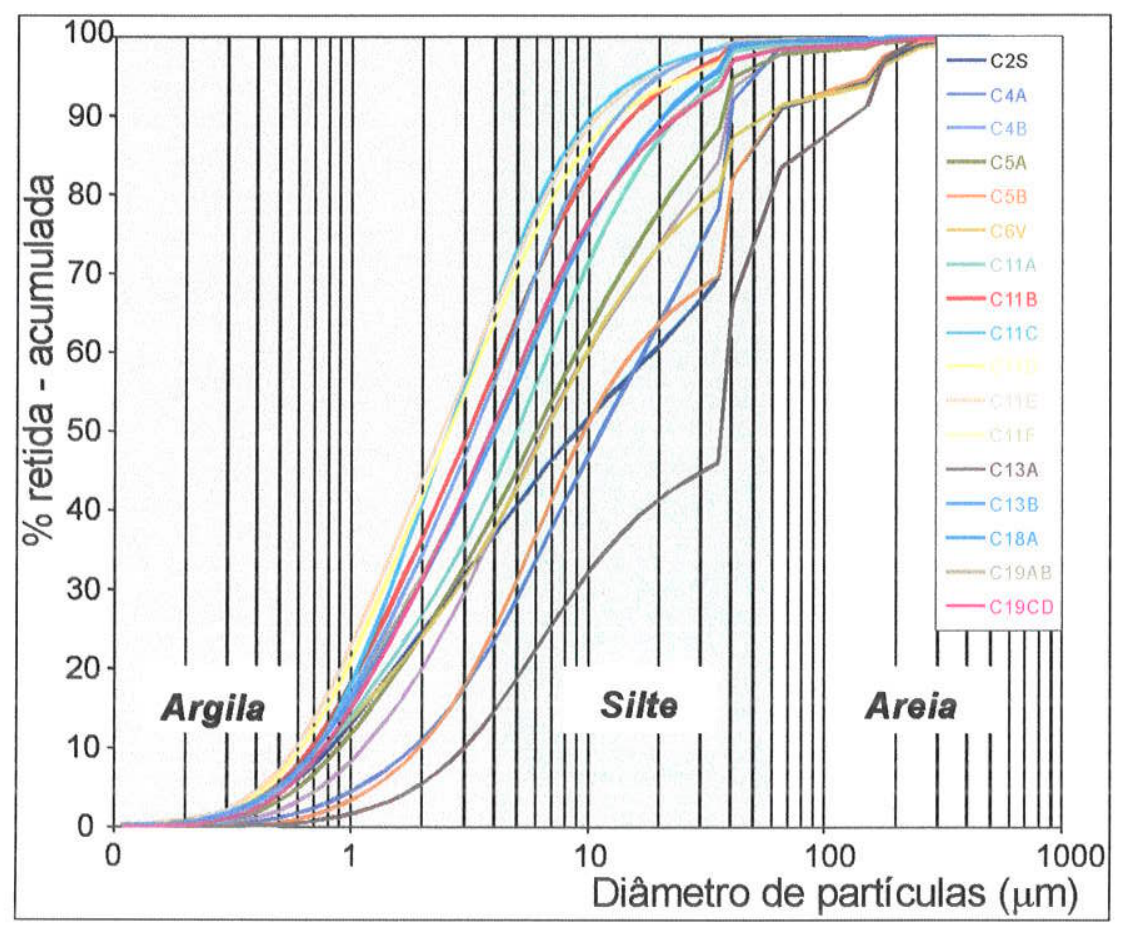

Figura 6.4: Distribuição granulométrica acumulada para as 17 amostras selecionadas.

As fortes inflexões observadas na dimensão de $44 \mu \mathrm{mm}$ resultaram da recomposição da curva granulométrica a partir dos dados obtidos nos dois métodos empregados, não denotando anomalias ou incorreções na avaliação.

Do total de 17 amostras analisadas, 14 mostraram distribuições muito semelhantes, com a maioria das partículas concentradas nas frações silte e argila. Somente as amostras C4B, C5B e C13A apresentaram composições mais arenosas.

Para a classificação granulométrica dos sedimentos e da nomenclatura da rocha foram empregados os diagramas ternários de Shepard (1954) e de Folk (1974), respectivamente, conforme apresentado nas Figuras 6.5 e 6.6. Nos vértices dos diagramas ternários foram utilizadas as frações areia $(>0,62 \mathrm{~mm})$, silte $(0,004-0,62 \mathrm{~mm})$ e argila $(<0,004 \mathrm{~mm})$. Através desses gráficos foi feito o refinamento interpretativo dos dados. De forma que, no grupo de amostras aparentemente homogêneo na distribuição acumulada materiais mais siltosos (argila siltosa) distinguiram-se dos mais argilosos (silte argiloso). As amostras mais arenosas classificaram-se como silte arenoso (Figura 6.4). 


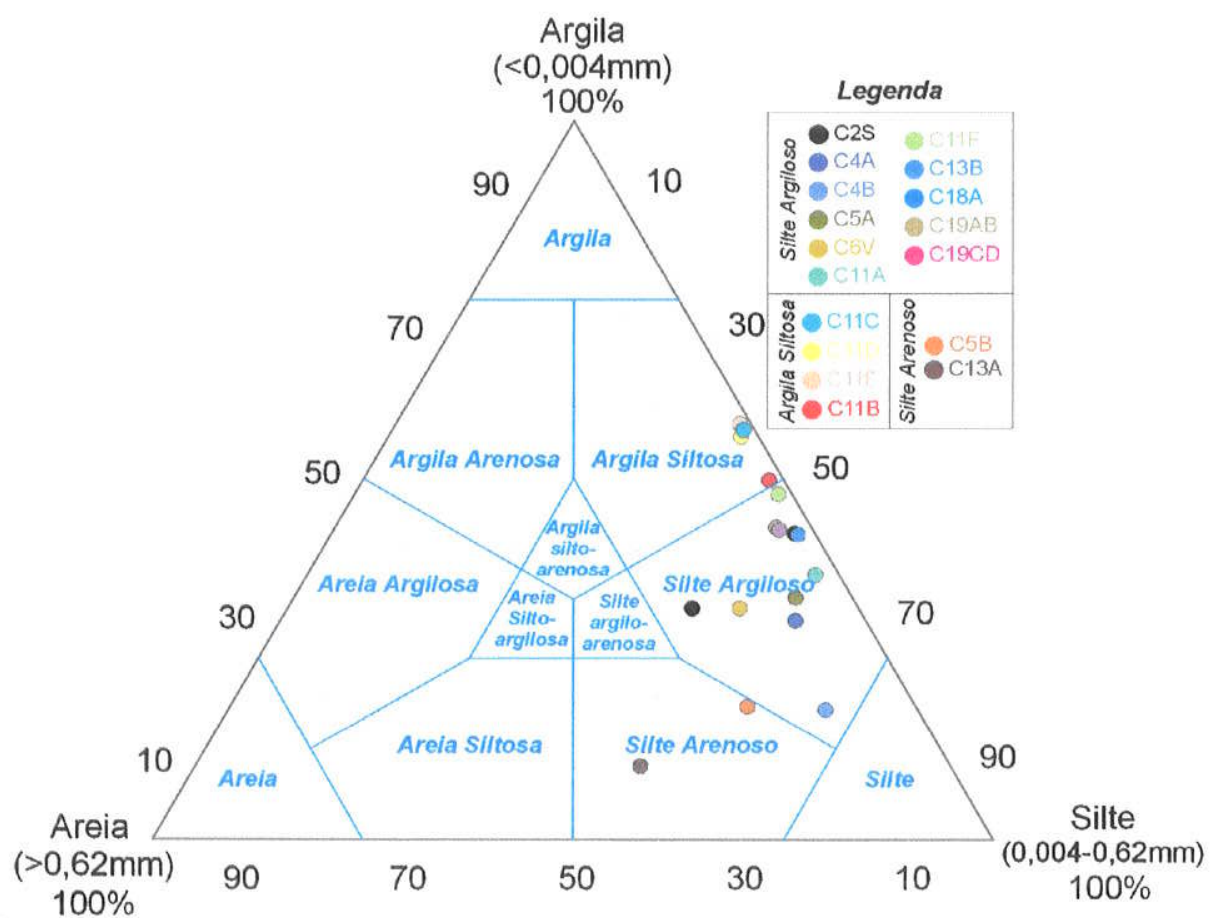

Figura 6.4: Diagrama ternário de Shepard (1954) para classificação de sedimentos com base na distribuição granulométrica.

Segundo a classificação de Folk (1974) para rochas sedimentares, as amostras estudadas enquadraram-se em lamitos, lamitos arenosos e siltitos arenosos (Figura 6.5). Em ambas as classificações não foram observadas populações nitidamente distintas, apenas gradações entre materiais mais grossos e mais finos.

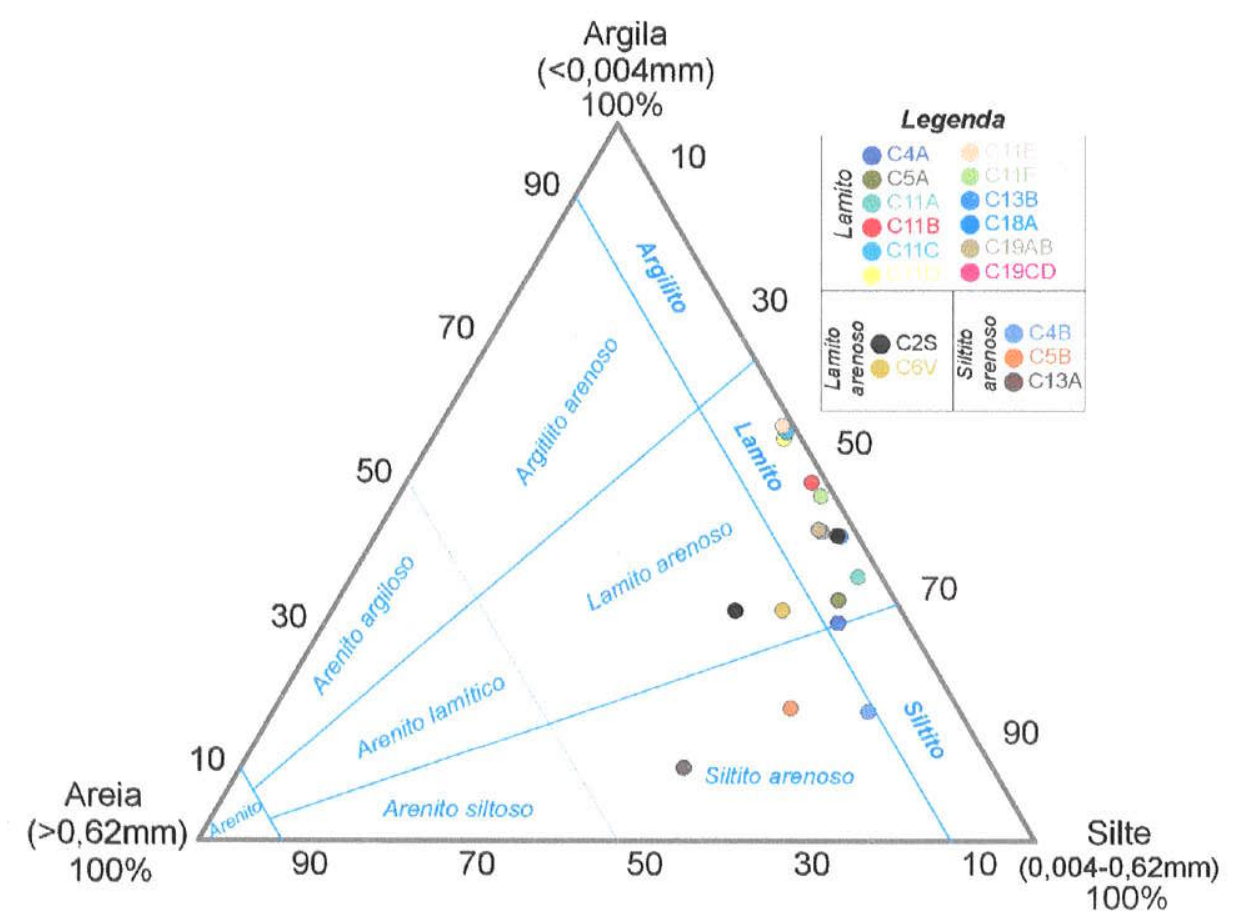

Figura 6.5: Diagrama triangular de Folk (1974) para classificação de rochas sedimentares. 
Além das classificações de Folk e Shepard foram determinadas as medianas $\left(D_{50 \%}\right)$, parâmetro comumente empregado na caracterização de matérias-primas cerâmicas. Para a sistematização da caracterização optou-se pela classificação de Folk (1974), desde que se tratam de rochas sedimentares, tendo as amostras recebido a nomenclatura de lamitos, lamitos arenosos e siltitos arenosos. A Tabela 6.2 resume as classificações obtidas para cada uma das amostras segundo os critérios adotados.

Tabela 6.2: Classificação das amostras segundo mediana $\left(D_{50 \%}\right)$, Shepard (1954) e Folk (1974)

\begin{tabular}{|c|c|c|c|c|c|c|}
\hline \multirow[b]{2}{*}{ Amostra } & \multicolumn{3}{|c|}{ Frações } & \multirow[b]{2}{*}{$D_{50 \%}$} & \multicolumn{2}{|c|}{ Classificação } \\
\hline & $\begin{array}{c}\% \text { Areia } \\
(>0,62 \mathrm{~mm})\end{array}$ & $\begin{array}{c}\% \text { Silte } \\
(0,004-0,62 \mathrm{~mm})\end{array}$ & $\begin{array}{c}\text { \% Argila } \\
(<0,004 \mathrm{~mm})\end{array}$ & & $\begin{array}{c}\text { Shepard } \\
\text { (sedimentos) }\end{array}$ & $\begin{array}{c}\text { Folk } \\
\text { (rochas sedimentares) }\end{array}$ \\
\hline C 2S & 19,17 & 48,23 & 32,60 & 10,48 & Silte argiloso & Lamito arenoso \\
\hline $\bar{C} 4 \mathrm{~A}$ & 7,60 & 61,55 & 30,85 & 7,72 & Silte argiloso & Lamito \\
\hline C 4B & 9,64 & 71,98 & 18,38 & 12,2 & Silte & Siltito arenoso \\
\hline C $5 A$ & 5,96 & 60,11 & 33,94 & 6,6 & Silte argiloso & Lamito \\
\hline C 5B & 19,19 & 61,88 & 18,92 & 10,48 & Silte arenoso & Siltito arenoso \\
\hline $\mathrm{C} 6 \mathrm{~V}$ & 13,53 & 54,06 & 32,41 & 7,72 & Silte argiloso & Lamito arenoso \\
\hline C 11A & 2,25 & 60,71 & 37,04 & 5,7 & Silte argiloso & Lamito \\
\hline $\mathrm{C} 11 \mathrm{~B}$ & 1,01 & 48,82 & 50,17 & 3,6 & argila siltosa & Lamito \\
\hline C 11C & 0,57 & 42,03 & 57,39 & 3,1 & argila siltosa & Lamito \\
\hline C 11D & 1,37 & 42,44 & 56,19 & 3,1 & argila siltosa & Lamito \\
\hline C 11E & 0,61 & 41,31 & 58,08 & 3,1 & argila siltosa & Lamito \\
\hline C 11F & 0,97 & 50,67 & 48,36 & 3,8 & Silte argiloso & Lamito \\
\hline C $13 \mathrm{~A}$ & 36,28 & 53,08 & 10,64 & 45,87 & Silte arenoso & Siltito arenoso \\
\hline C 13B & 1,49 & 55,78 & 42,73 & 4,88 & Silte argiloso & Lamito \\
\hline C 18A & 1,78 & 55,30 & 42,92 & 4,88 & Silte argiloso & Lamito \\
\hline C 19AB & 3,24 & 53,35 & 43,41 & 4,66 & Silte argiloso & Lamito \\
\hline C 19CD & 3,40 & 52,81 & 43,79 & 4,54 & Silte argiloso & Lamito \\
\hline
\end{tabular}

\subsection{Composição Química}

As composições químicas em óxidos das 17 amostras selecionadas são apresentadas na Tabela 6.3.

A análise dos dados feita segundo o agrupamento em litotipos, permitiu a observação de distribuição mais homogênea dos teores, indicando a dependência entre a composição química e a distribuição granulométrica. Essa correlação tornou-se mais evidente em amostras de lamitos cuja variação percentual fol inferior a $5 \%$ para $\mathrm{SiO}_{2}$ e $\mathrm{Al}_{2} \mathrm{O}_{3}$, porém não foi válida quando considerados os teores de outros elementos.

As maiores variações para $\mathrm{SiO}_{2}$ e $\mathrm{Al}_{2} \mathrm{O}_{3}$ dentro de um mesmo litotipo foram observadas nos siltitos arenosos, possivelmente associadas às proporções da fração areno-quarztosa. 
Tabela 6.3: Composição química das amostras segundo os litotipos (\% em peso dos óxidos).

\begin{tabular}{|c|c|c|c|c|c|c|c|c|c|c|c|c|c|}
\hline \multicolumn{2}{|r|}{ Amostra } & $\mathrm{SiO}_{2}$ & $\mathrm{Al}_{2} \mathrm{O}_{3}$ & $\mathrm{Fe}_{2} \mathrm{O}_{3}$ & $\mathrm{TiO}_{2}$ & $\mathrm{~K}_{2} \mathrm{O}$ & $\mathrm{CaO}$ & MgO & Mno & $\mathrm{P}_{2} \mathrm{O}_{5}$ & $\mathrm{Na}_{2} \mathrm{O}$ & $\begin{array}{c}\mathrm{PF} \\
\left(1000^{\circ} \mathrm{C}\right)\end{array}$ & Total \\
\hline \multirow{14}{*}{$\stackrel{8}{\frac{8}{3}}$} & C5A & 53,16 & 24,67 & 7,45 & 1,14 & 2,27 & 0,06 & 01 & 0,02 & 0,08 & $0,01^{*}$ & 9,81 & 99,67 \\
\hline & C11A & 1,96 & 26,80 & 6,21 & 1,35 & 2,10 & 0,23 & 0,75 & .01 & 0,08 & $<0,01^{*}$ & 9,80 & 99,29 \\
\hline & C11B & 70 & 6,89 & 94 & 1,29 & 1,90 & 32 & 87 & 02 &, 09 & & 10,14 & 0,16 \\
\hline & C11C & 52,07 & 5,28 & 49 & 1,34 & 1,97 & 0,38 & 0,02 & 0,02 & 0,08 & $<0,01^{*}$ & 9,71 & 9,36 \\
\hline & C11D & 0,46 & 3,87 & 22 & 1,27 & 1,64 & 0,38 & 87 & 01 & 0,08 & $<0,01^{*}$ & 10,64 & 9,45 \\
\hline & & 0,79 & 7,53 & 6,81 & 1,28 & 1,65 & 37 & 0,85 & 0,01 & 0,07 & $<0,01^{*}$ & 10,39 & 99,76 \\
\hline & $\mathrm{C} 11 \mathrm{~F}$ & 0,62 & 7,52 & 6,79 & 1,28 & 1,65 & 0,36 & 0,86 & 01 & 0,07 & $<0,01^{*}$ & 10,82 & 9,98 \\
\hline & &, 00 & 26,17 & 9,21 & 1,23 & 1,91 & 21 & 0,83 & 0,02 & 0,09 & $<0,01^{*}$ & 10,33 & 100,00 \\
\hline & C18A & 50,24 & 25,26 & 9,67 & 1,24 & 1,94 & 0,07 & 0,72 & 0,02 & 0,08 & $<0,01^{*}$ & 10,17 & 9,41 \\
\hline & & & 25,08 & 14 & 1,19 & 34 & & 59 & & 07 & & 10,38 &, 52 \\
\hline & C19CD & 52,64 & 25,51 & 8,19 & 1,20 & 1,93 & 0,04 & 0,66 & 0,01 & 0,07 & $<0,01^{*}$ & 9,62 & 9,88 \\
\hline & édia & 51,44 & 26,14 & 74 & 1,26 & 1,89 & 0,22 & 0,73 & 0,02 & 0,08 & -009 & 10,16 & 9,68 \\
\hline & & $\pm 1,06$ & 1,03 & 1,09 & $\pm 0,06$ & $\pm 0,19$ & $\pm 0,15$ & $\pm 0,26$ & $\pm 0,00$ & $\pm 0,01$ & 0 & $\pm 0,39$ & $\pm 0,29$ \\
\hline & $\begin{array}{r}D e \\
\text { relat }\end{array}$ & & 3,93 & 1,11 & 5,00 & 10,30 & 66,60 & 36,01 & 22,40 & 9,34 & 0 & 3,86 &, 30 \\
\hline & & & & & & & & & & & & & \\
\hline \multirow{6}{*}{$\begin{array}{l}0 \\
8 \\
5 \\
0 \\
0 \\
\frac{8}{E} \\
\mathbb{J}\end{array}$} & & 60,48 & 22,11 & 5,72 & 0,99 & 1,82 & 0,03 & 0,47 & 0,01 & 0,06 & $<0,01^{*}$ & 8,44 & 100,12 \\
\hline & & 6,63 & 23,52 & 6,89 & 1,11 & 2,19 & & 0,75 & 0,02 & 0,07 & $<0,01^{*}$ & 8,71 & \\
\hline & $6 \mathrm{~V}$ & 51,70 & 26,88 & 7,40 & 1,28 & 1,68 & 0,03 & 0,63 & 0,02 & 0,10 & $<0,01^{*}$ & 10,29 & 100,01 \\
\hline & Média & 56,27 & 24,17 & 67 & 1,13 & 1,90 & 0,03 & 0,62 & 0,01 & 0,07 & $<0,01$ & 9,15 & 100,02 \\
\hline & & $\pm 4,40$ & $\pm 2,45$ & $\pm 0,86$ & $\pm 0,15$ & $\pm 0,26 \mid$ & $\pm 0,00$ & $\pm 0,14$ & $\pm 0,01$ & $\pm 0,02$ & 0 & $\pm 1,00$ & $\pm 0,10$ \\
\hline & $\begin{array}{c}\text { Desvio } \\
\text { relativo (\% }\end{array}$ & 7,82 & 10,14 & 12,91 & 13,22 & 13,89 & 0,00 & 22,78 & 37,55 & 30,55 & 0 & 10,93 & 0,10 \\
\hline \multirow{6}{*}{$\begin{array}{l}8 \\
8 \\
6 \\
8 \\
8\end{array}$} & & & & & & & & & & & & 8,49 & 0.98 \\
\hline & & & 17,13 & & 0,77 & 2,47 & & & & & & 6,44 & 9,55 \\
\hline & $\mathrm{C} 13 \mathrm{~A}$ & 74,25 & 14,26 & 2,62 & 0,56 & 3,03 & 0,05 & 0,16 & 0,00 & 0,05 & $<0,01$ & 4,13 & 99,16 \\
\hline & Média & 66,71 & 18,13 & 4,55 & 0,83 & 2,71 & 0,05 & 0,47 & 0,01 & 0,06 & $<0,01$ & 6,35 & 99,89 \\
\hline & & $\pm 8,01$ & $\pm 4,46$ & 1,91 & $\pm 0,31$ & $\pm 0,29$ & $\pm 0,02$ & $\pm 0,34$ & $\pm 0,01$ & $\pm 0,01$ & 0 & $\pm 2,18$ & $\pm 0,96$ \\
\hline & $\begin{array}{c}\text { Desvio } \\
\text { relativo (\%) }\end{array}$ & 12,01 & 24,60 & 41,96 & 36,60 & 10,64 & 40,00 & 71,22 & 85,44 & 10,21 & 0 & 34,33 & 0,96 \\
\hline
\end{tabular}

$<0,01$ - abaixo do limite de detecção analítica

P.F. - Perda ao fogo à $1000^{\circ} \mathrm{C}$. 


\subsection{Identificação Mineralógica}

A determinação da assembléia mineralógica baseou-se principalmente em interpretações de difratogramas de raios $X$. Auxiliaram também, os resultados de análises químicas, termogravimétricas e termodiferenciais.

A apresentação dos resultados da difração de raios $X$ seguiu a ordem de preparação das amostras, frações granulométricas analisadas e tratamentos executados:

- Amostra tal qual (natural);

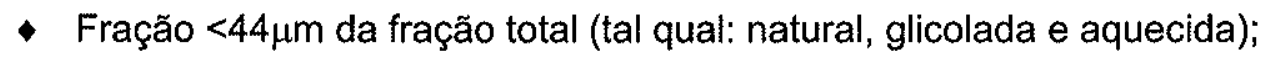

- Fração <2 $4 \mathrm{~m}$ da amostra tal qual (natural, glicolada e aquecida);

- Fração $<2 \mu \mathrm{m}$ da amostra tal qual (após trocas catiônicas, glicoladas e aquecidas).

\subsubsection{Amostra tal qual}

Foram selecionadas três amostras representativas, C6V, C11 e C19, para a identificação detalhada.

As amostras C11 e C19 apresentaram assembléias mineralógicas muito semelhantes, com caulinita, illita, esmectita, quartzo e feldspato. A amostra C6V, diferenciou-se das demais, pela ausência da esmectita, que deveria ser reconhecida pela reflexão basal (001) próxima de 15-16Å (Figura 6.6).

A esmectita foi reconhecida pela presença de reflexão basal do plano (001), próxima de 15-16 $\AA$, em amostras naturais, apresentada sempre sob a forma alargada e de baixa intensidade, refletindo a baixa cristalinidade.

A illita foi identificada pelo conjunto de reflexões dos planos paralelos à (001), nas distâncias 10,5 e $3,3 \AA$. Os picos mostraram-se levemente alargados e assimétricos, possivelmente pela presença de interestratificados de illita/esmectita.

A caulinita, por outro lado apresentou-se sempre com as reflexões basais de alta intensidade e picos agudos, revelando sua elevada cristalinidade. Esse argilomineral apresentou as principais reflexões a 7,0 e $3,5 \AA$.

O quartzo foi identificado em todas as amostras pelas reflexões características nas distâncias 4,46 e $3,33 \AA$, com picos agudos. 
As reflexões do feldspato ocorreram de forma bastante sutil nos difratogramas, próximas de $3,24 \AA$. Embora não tenham sido reconhecidas nítidas reflexões de óxidos de ferro, sua presença foi sugerida pela característica ruidosa do perfil (background), possivelmente esteja presente em formas amorfas.

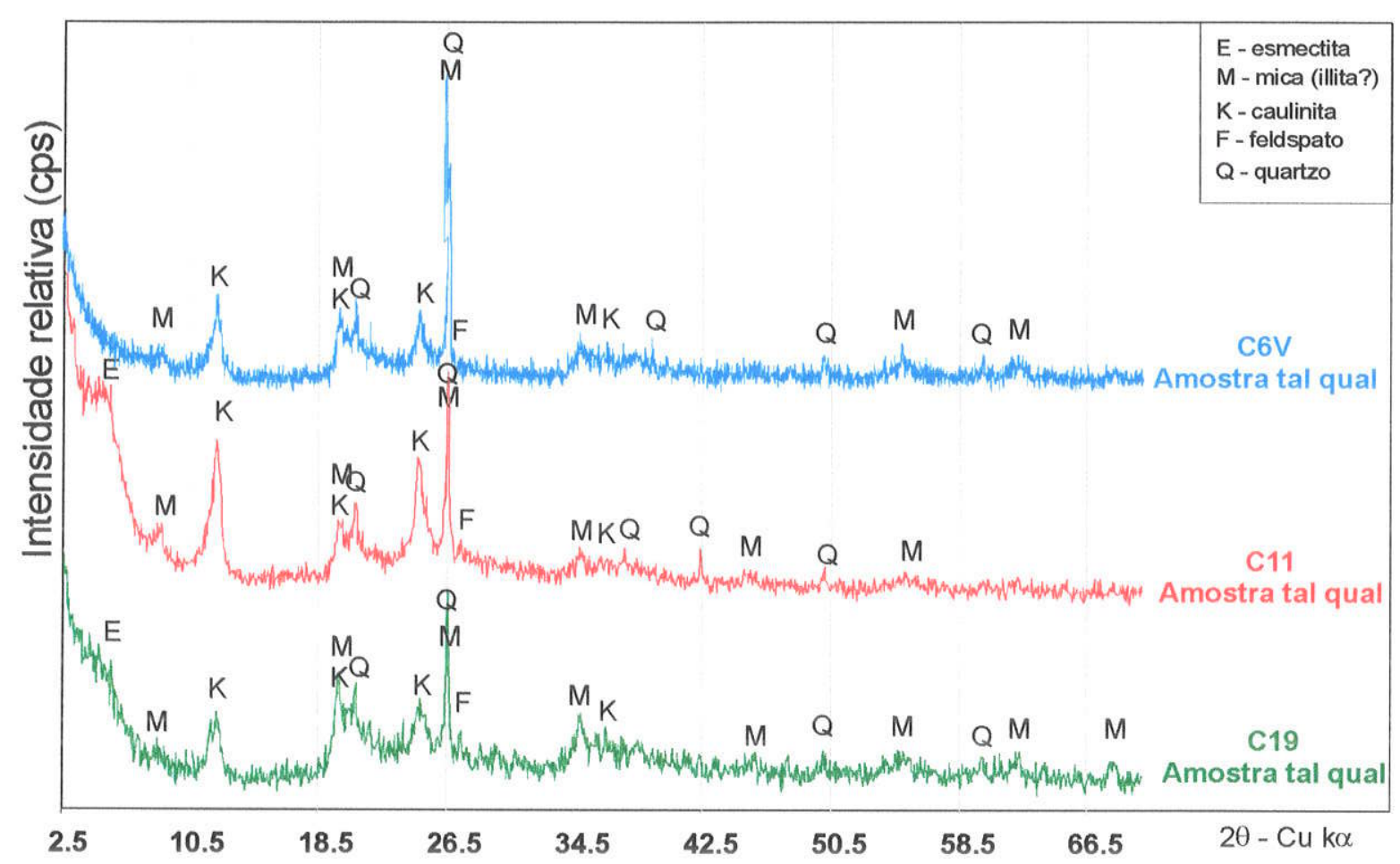

Figura 6.6 - Difratogramas para amostras naturais: C6V (lamito arenoso), C11 e C19 (lamitos).

\subsubsection{Fração $<44 \mu \mathrm{m}$ da amostra natural}

Foram analisadas as 17 amostras iniciais, produtos de peneiramento a úmido. Os resultados serão apresentados segundo o agrupamento adotado: lamitos, lamitos arenosos e siltitos arenosos.

A fração $>44 \mu \mathrm{m}$ é basicamente constituída de quartzo, e pequenas quantidades $(<5 \%$ da fração) de feldspato caulinizado e mica (illita?), cujas proporções foram obtidas por estimativa ao estereomicroscópio.

Os lamitos e lamitos arenosos são essencialmente constituídos de esmectita, caulinita, illita e quartzo. Para os siltitos arenosos a elevada proporção de quartzo na fração resultou em difratogramas com picos agudos e de elevada intensidade relativos ao quartzo, com perfil ruidoso de background. 
Mesmo com a eliminação da fração mais quartzosa e após os tratamentos de glicolagem e aquecimento, não foi identificada a esmectita na amostra C6V. Nas demais amostras, repetindo os resultados obtidas para amostra totais, a esmectita apresentou somente a

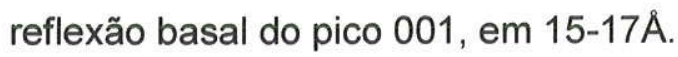

\section{a) Lamitos}

Para as frações $<44 \mu \mathrm{m}$ dos lamitos, os picos da caulinita mostraram maior intensidade que os da mica (illita?) e da esmectita. A esmectita foi identificada por apresentar reflexão basal (001) a cerca de $15 \AA$ em amostra natural, $18 \AA$ em amostra glicolada e a $10 \AA$ após aquecimento (Figuras 6.7 e 6.8 ).

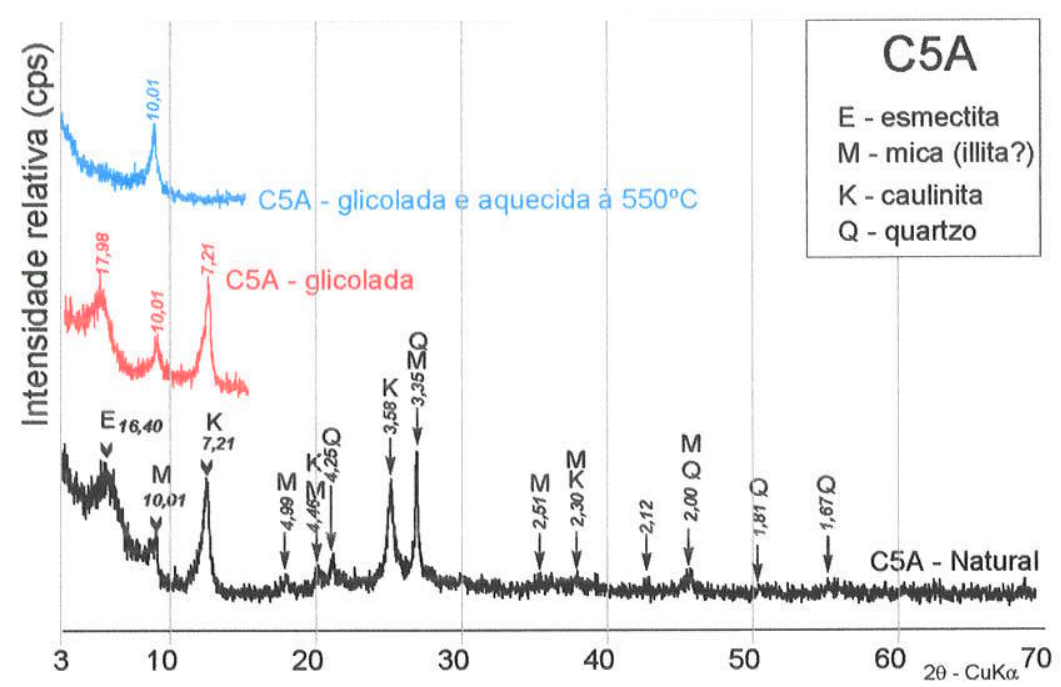

Figura 6.7: Difratograma da fração $<44 \mu m$ da amostra C5A (lamito).

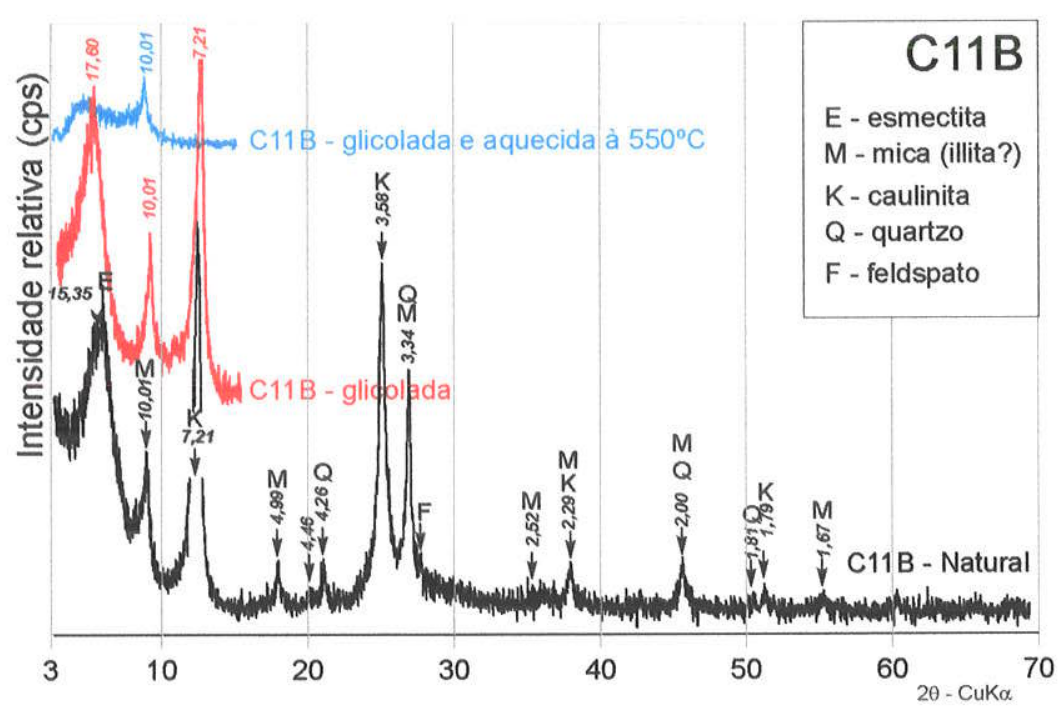

Figura 6.8: Difratograma da fração $<44 \mu \mathrm{m}$ da amostra C11B (lamito). 
A análise do difratograma C11 permitiu inferir certa monotonia composicional, evidenciada pela pequena variabilidade mineralógica ao longo do pacote sedimentar de 6m (Figura 6.9). O mesmo comportamento pôde ser observado em difratogramas de amostras da camada C19 com $3 \mathrm{~m}$ de espessura (Figura 6.10).

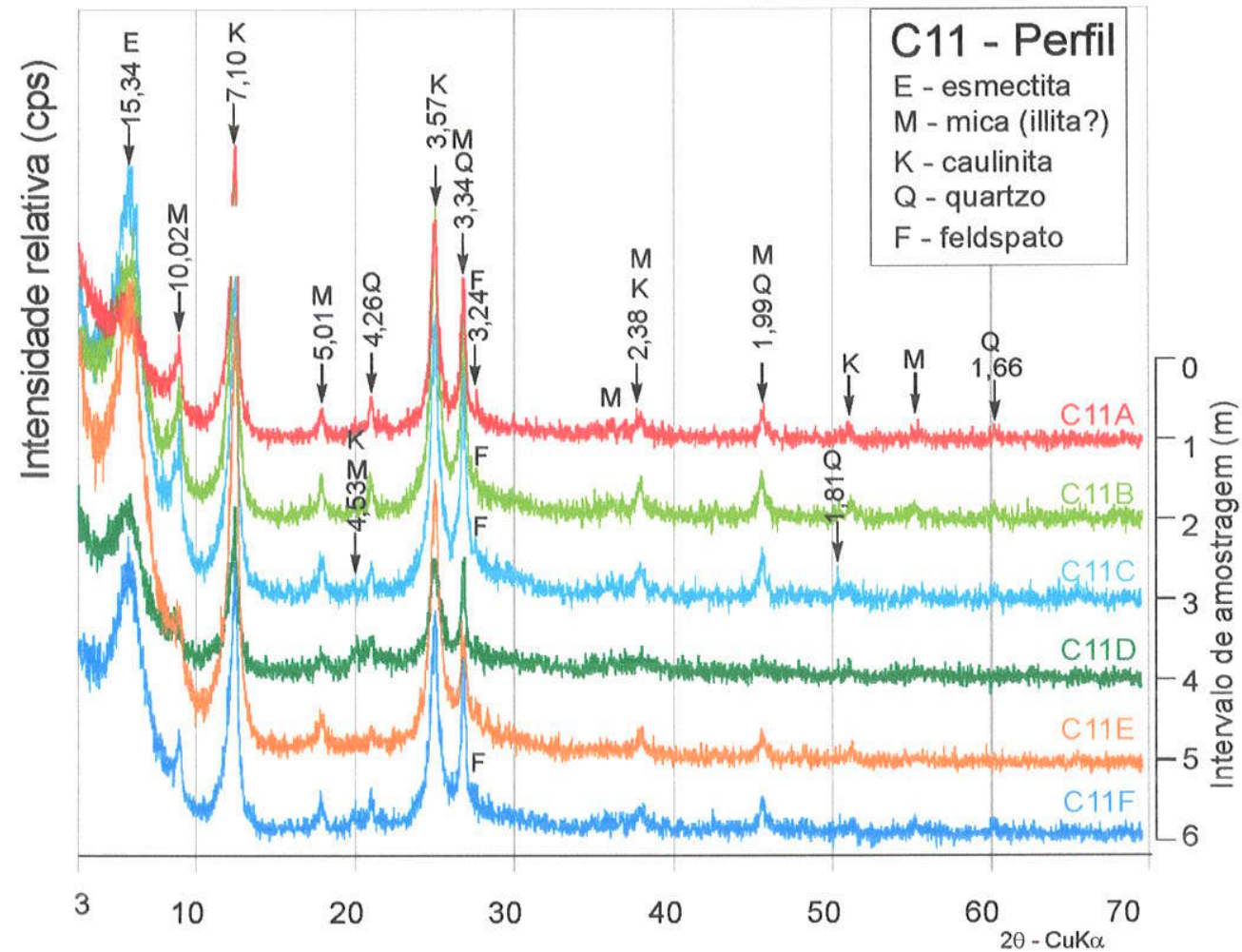

Figura 6.9: Difratograma da fração $<44 \mu \mathrm{m}$ das amostras C11A a C11F.

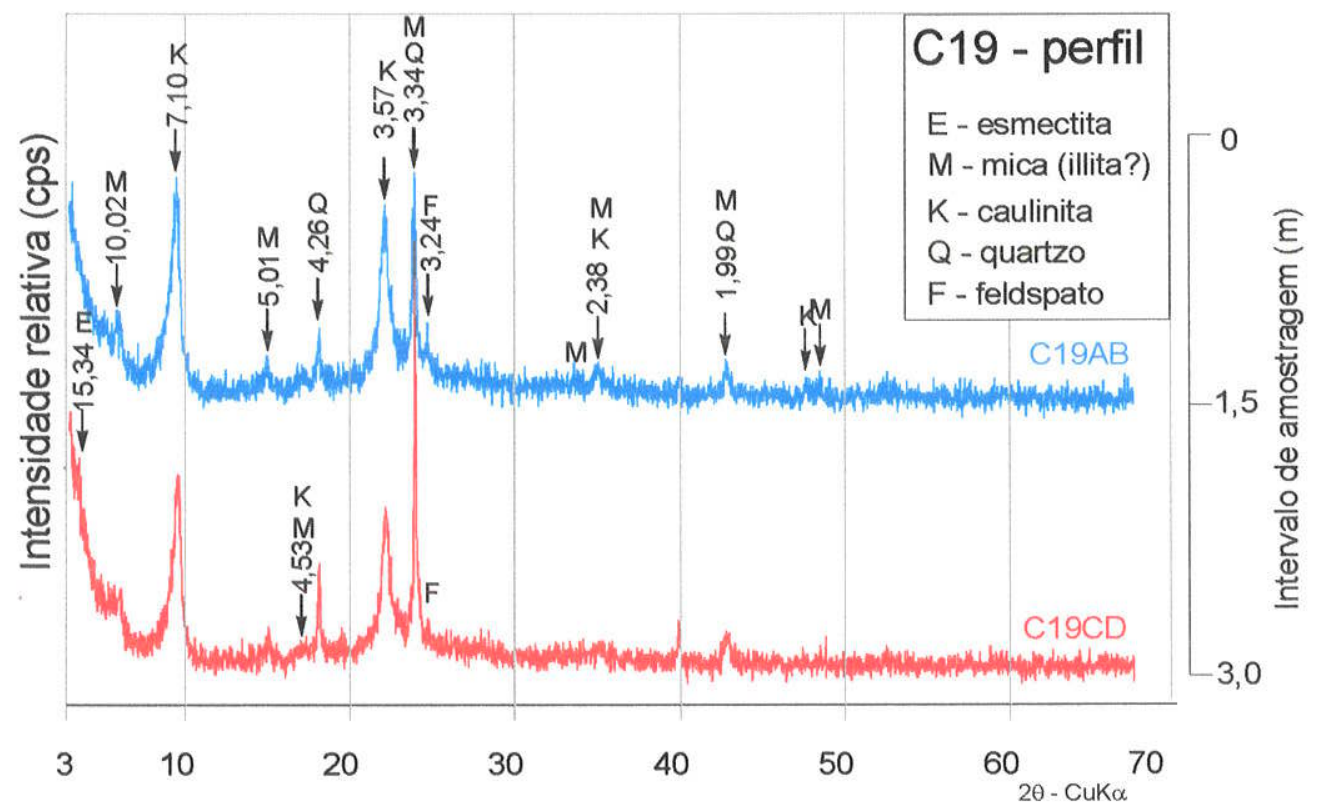

Figura 6.10: Difratograma da fração $<44 \mu m$ das amostras C19AB e C19CD. 


\section{b) Lamitos arenosos}

Os picos da caulinita apresentaram maior intensidade que os da mica (illita ?) e da esmectita. A esmectita semelhantemente ao que ocorreu para os lamitos, foi identificada por apresentar reflexão basal (001) a cerca de $15 \AA$ em amostra natural, $18 \AA$ em amostra glicolada e a $10 \AA$ após aquecimento (Figuras 6.11 e 6.12 ).

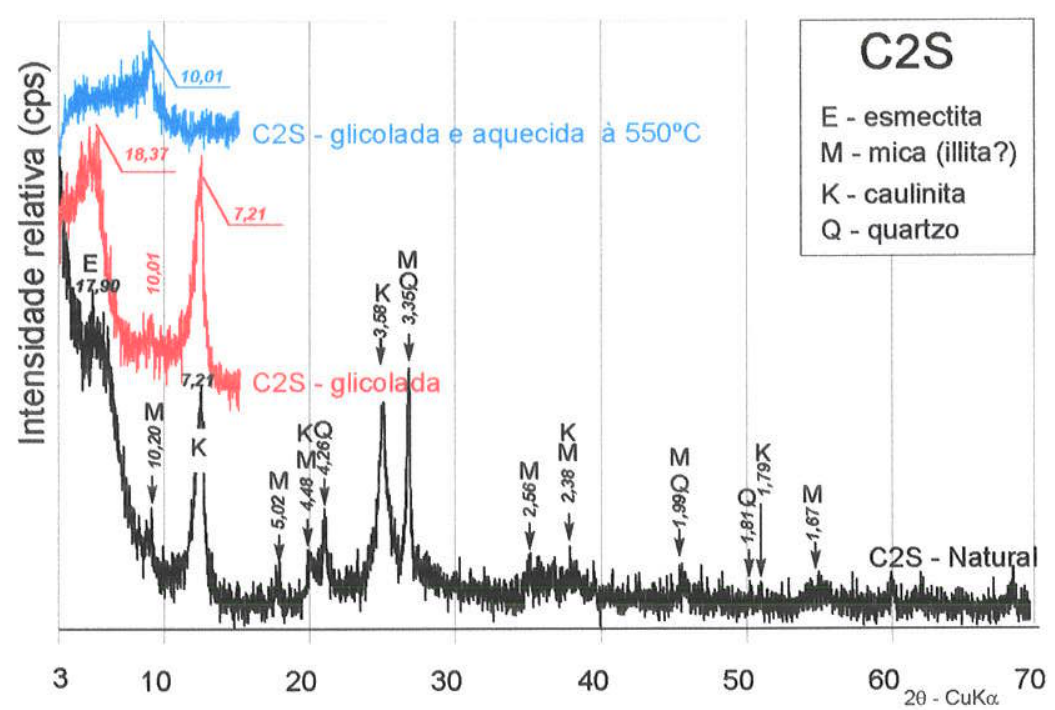

Figura 6.11: Difratograma da fração $<44 \mu m$ da amostra C2S (lamito arenoso).

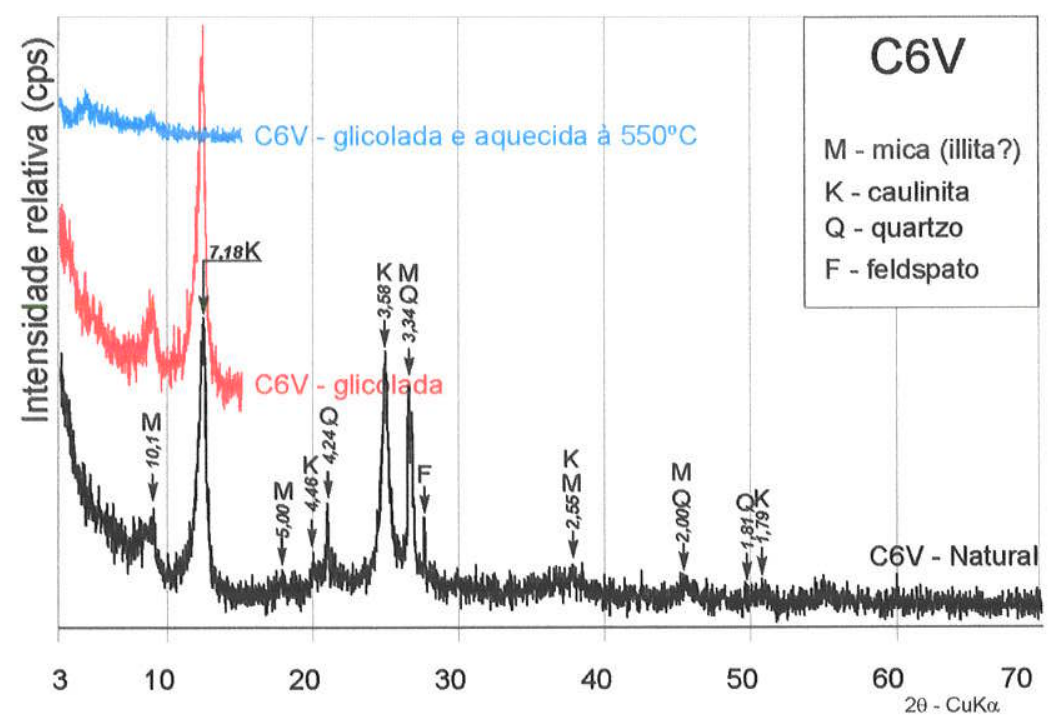

Figura 6.12: Difratograma da fração $<44 \mu \mathrm{m}$ da amostra C6V (lamito arenoso). 


\section{c) Siltitos arenosos}

Para as amostras de siltitos arenosos, analisadas na fração $<44 \mu \mathrm{m}$, como esperado o quartzo apresentou os picos de maior intensidade frente aos das caulinita, illita e esmectita. A esmectita foi identificada pelas reflexões basais (001) em amostra natural, e confirmada pelos tratamentos. A illita apresentou-se como componente comum a todas as amostras (Figuras 6.13).

A amostra C13A apresentou o pico a $3,24 \AA$ do feldspato mais bem definido, nas demais amostras o feldspato apareceu pouco definido, certamente pela alteração supérgena que pode tê-lo transformado em caulinita.

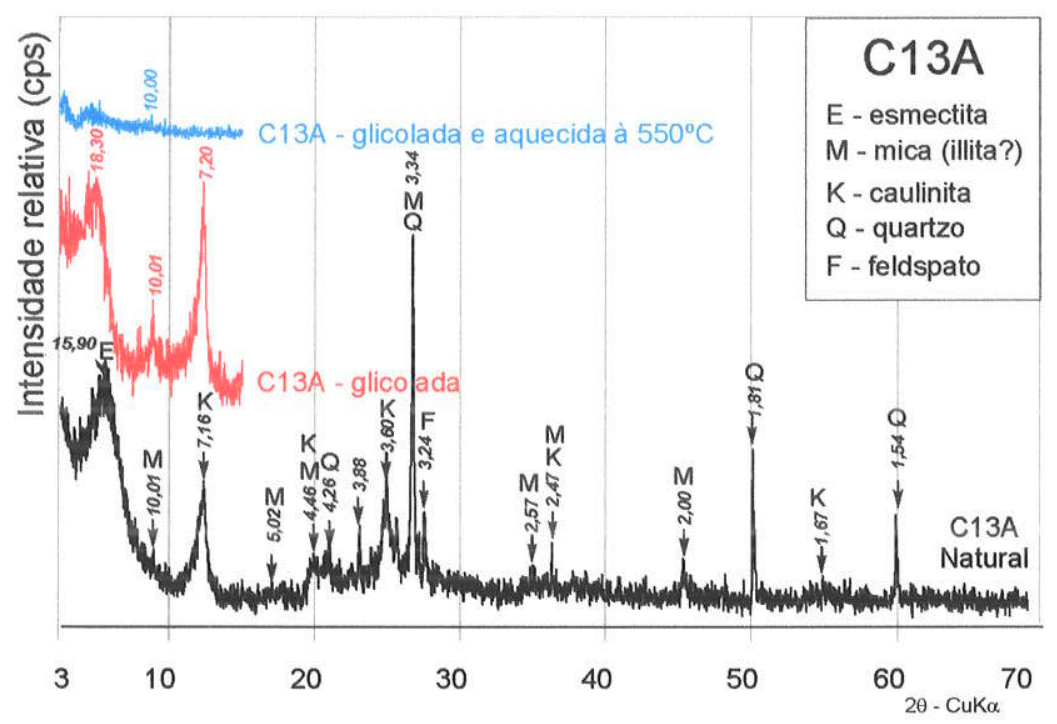

Figura 6.13: Difratograma da fração $<44 \mu \mathrm{m}$ da amostra C13A (siltito arenoso).

\subsubsection{Fração < $2 \mu \mathrm{m}$ para identificação dos argilominerais}

Foram realizadas análises difratrométricas na fração $<2 \mu \mathrm{m}$ de três amostras C6V, C11 e C19, buscando-se o refinamento na identificação dos argilominerais. Os resultados obtidos são apresentados nas Figuras 6.14a a 6.14c.

A esmectita é facilmente identificada através da comparação dos padrões difratométricos de amostras secas ao ar com amostras solvatadas com etilenoglicol (glicolagem) (Moore \& Reynolds, 1997). Após a solvatação com etilenoglicol o pico (001) desloca-se de $15 \AA$ para a $16,9 \AA$. Com o aquecimento à $500-550^{\circ} \mathrm{C}$ espera-se que o pico de $16,9 \AA$ seja deslocado para $10 \AA$, em função do colapso da estrutura cristalina ocasionada pela remoção de hidroxilas. 
Para as amostras analisadas verificou-se que a expansão ocorreu de $\sim 16 \AA$ para $18-19 \AA$, valores pouco comuns quando comparados com os da literatura. Após o aquecimento,

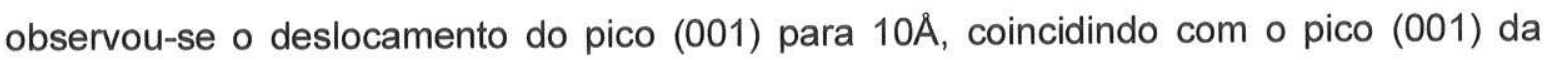
illita. Possivelmente a diferença na posição do pico em relação ao descrito na literatura, se tenha sido provocada pela baixa cristalinidade das esmectitas nesses materiais.

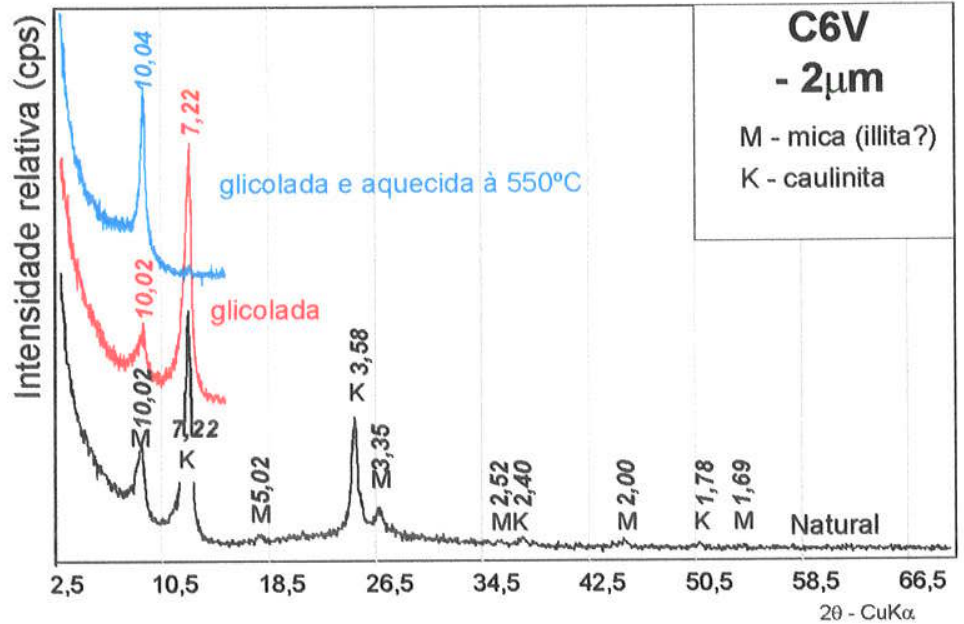

(a)

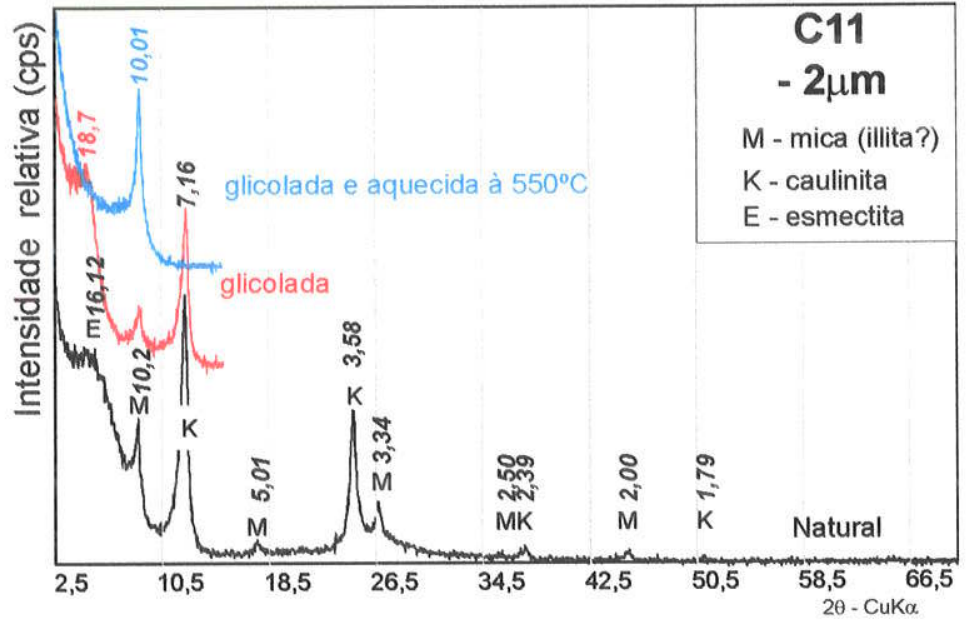

(b)

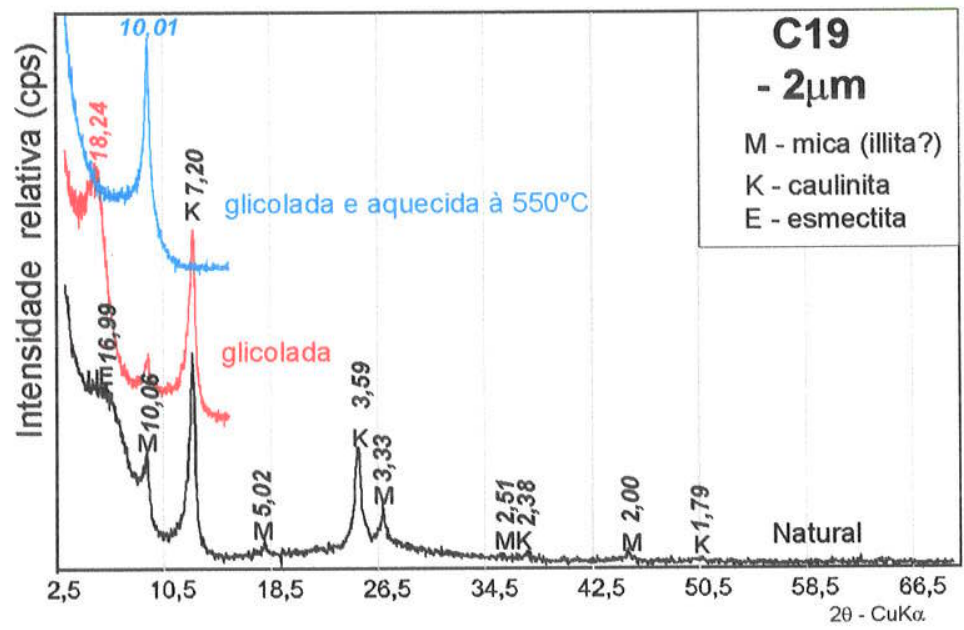

(c)

Figuras 6.14: (a), (b) e (c) Difratogramas das frações <2 $\mu \mathrm{m}$ com identificação de grupos de argilominerais. 
A confirmação da presença de minerais do grupo das esmectitas foi obtida através da saturação com solução de $\mathrm{KCl}$, seguida de aquecimento a $300^{\circ} \mathrm{C}$. O pico (001) da esmectita apresentou a reflexão basal novamente sobreposta ao da illita. Nesse tratamento, os demais argilominerais não sofreram quaisquer modificações.

Prosseguindo-se as investigações, buscou-se refinar a identificação da espécie esmectita, através de outras saturações. O teste Greene-Kelly, que consiste na saturação com solução salina de lítio (Greene-Kelly apud Moore \& Reynolds, 1997), permite diferenciar a montmorillonita da nontronita, saponita e beidellita. Essas espécies saturadas com lítio e aquecida a $300^{\circ} \mathrm{C}$, apresentam a reflexão basal à $10 \AA$. Após a saturação somente na montmorillonita não se observa o deslocamento do pico (001) para 17A. A distinção final entre beidellita e os demais componentes do grupo é obtida pela saturação com solução de $\mathrm{MgCl}_{2}$, seguida de solvatação com glicerol, na qual ocorre o aparecimento do pico próximo de $13 \AA$, característico da beidellita.

Os difratogramas obtidos após os tratamentos impostos às frações <2 $\mu \mathrm{m}$, mostraram que a variedade de esmectita presente nas amostras em estudo é a beidellita. Esse fato corroborou os dados obtidos por Sant'Anna (1999) que identificou beidellita em amostras de lamitos da Formação Resende. 


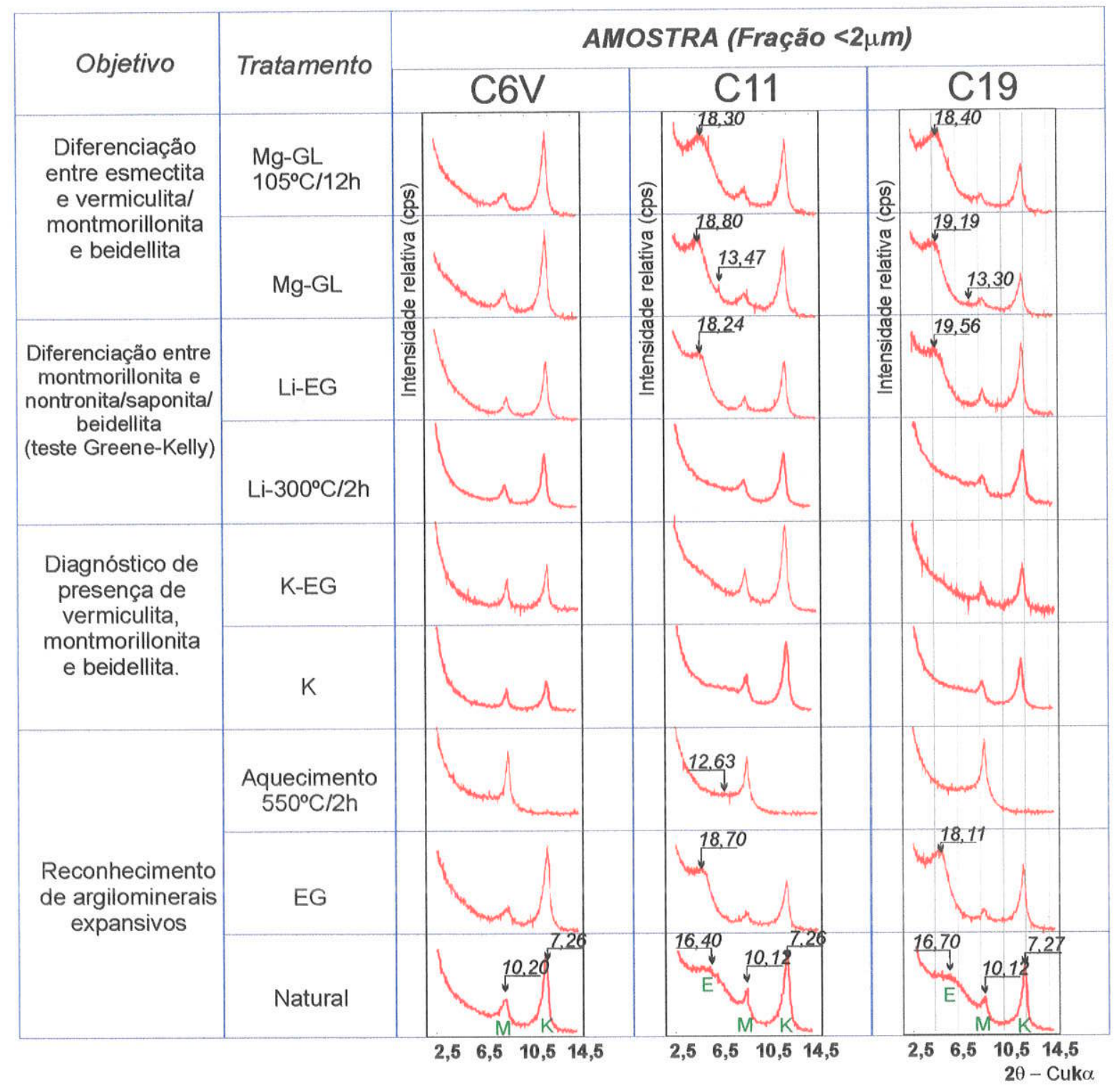

Figura 6.15: Difratogramas da fração $<2 \mu \mathrm{m}$ de amostra tal qual com determinação das espécies de argilominerais. (GL - glicerol; EG - etilenoglicol)

Reconheceu-se a existência de interestratificados de illita/esmectita através da análise do pico 001 a $10 \AA$, em amostra natural, que apresentou forma alargada e assimétrica. Após glicolagem notou-se a expansão parcial, com o surgimento de um pico a $10,3 \AA$, que desapareceu após o aquecimento a $550^{\circ} \mathrm{C}$, que ressaltou apenas o pico mais agudo da mica (illita) (Figura 6.16). A forma alargada e assimétrica do pico (001) da illita foi igualmente observada em outras amostras.

Argilominerais de camadas mistas de caulinita/illita; caulinita/esmectita não foram reconhecidos nas amostras analisadas. 


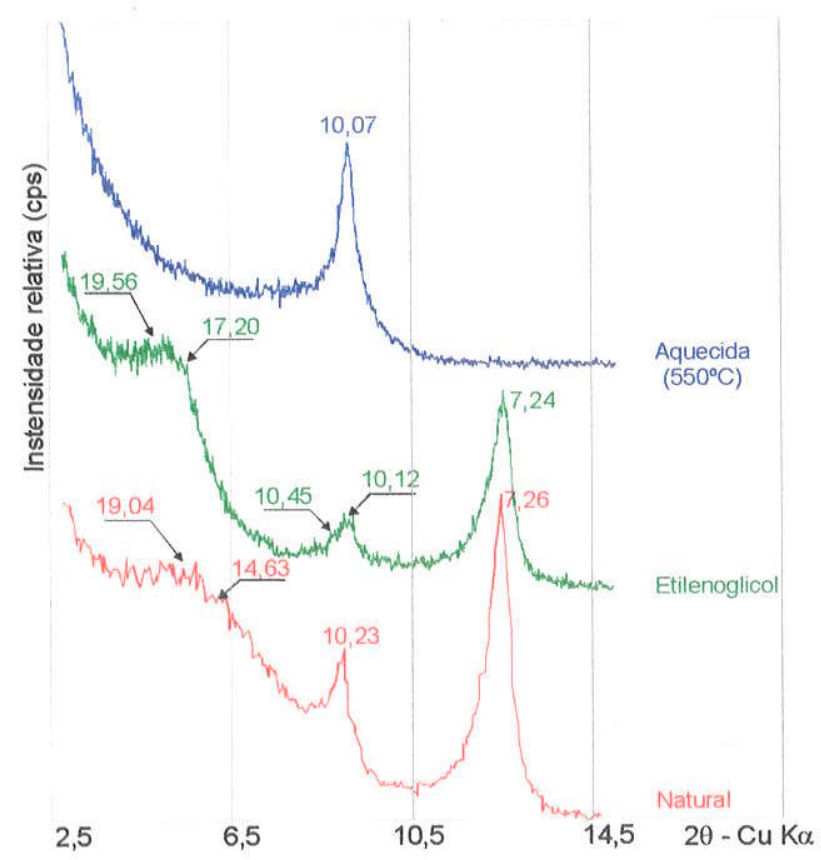

Figura 6.16: Difratogramas da fração $<2 \mu \mathrm{m}$ da amostra tal qual $\mathrm{C} 11$ natural, glicolada e aquecida a $550^{\circ} \mathrm{C}$.

\subsection{Capacidade de troca catiônica}

Os resultados de capacidade de troca catiônica (CTC) das 17 amostras analisadas apresentaram pouca variação relativa, mesmo entre litotipos distintos (Tabela 6.4).

A CTC das amostras de lamito variou entre 25 e $47 \mathrm{meq} / 100 \mathrm{~g}$, com média de $39 \mathrm{meq} / 100 \mathrm{~g}$. Valores de CTC de 33 e $37 \mathrm{meq} / 100 \mathrm{~g}$ (média de $35 \mathrm{meq} / 100 \mathrm{~g}$ ) foram obtidos para as duas amostras de lamito arenoso, enquanto que os resultados para o siltito arenoso variaram entre 36 e $44 \mathrm{meq} / 100 \mathrm{~g}$, com média de $39 \mathrm{meq} / 100 \mathrm{~g}$. Os siltitos e lamitos arenosos mostraram as menores variações nos resultados, devido ao pequeno número de amostras avaliadas.

Dos cátions trocáveis analisados, apenas os íons sódio e potássio apresentaram variações nas concentrações inferiores a $27 \%$, enquanto que os demais mostraram grandes discrepâncias relativas, mesmo quando foram comparadas amostras sotopostas, como as do perfil lamítico C11 e C19.

Mesmo com variações, os resultados obtidos foram considerados válidos, uma vez que os valores de CTC de argilominerais reportados na literatura apresentam variações superiores a 50\%, como por exemplo Grim (1968) apresentou valores de CTC de alguns argilominerais: 5 a $15 \mathrm{mmeq} / 100 \mathrm{~g}$ (caulinita; 15 a $40 \mathrm{meq} / 100 \mathrm{~g}$ (illita) e 80 a $150 \mathrm{meq} / 100 \mathrm{~g}$ (esmectita). 
Tabela 6.4: Capacidade de troca catiônica calculada das 17 amostras.

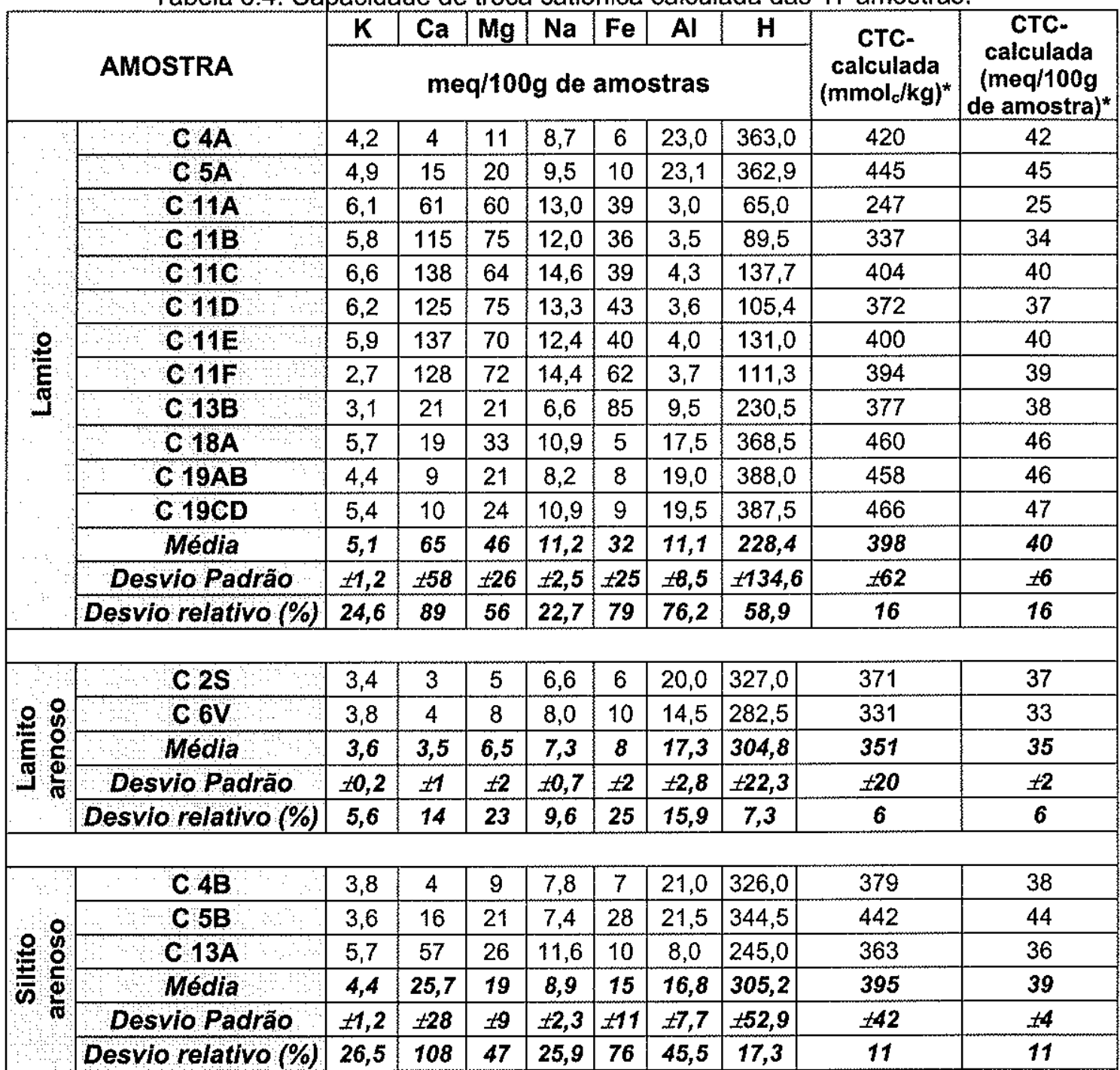

*Os resultados apresentam-se em mmol $/ \mathrm{kg}$ (milimol-carga/kg - Sistema Internacional) e meq $/ 100 \mathrm{~g}$ de amostra (miliequivalentes $/ 100 \mathrm{~g}$ de amostra analisada - unidade usual).

A assembléia mineralógica das amostras é basicamente formada por argilominerais (caulinita, illita, esmectita e interestratificados de illita/esmectita ), e pequenas proporções de quartzo e feldspato, e pode-se considerar que o valor de CTC obtido resultou da soma das CTC parciais de cada um dos componentes argilosos.

Se forem comparados os valores de CTC reportados para argilominerais (Figura 6.17) e os resultados obtidos neste trabalho, a esmectita compõe cerca de $50 \%$ das amostras, pois o maior valor de CTC obtido foi de $47 \mathrm{meq} / 100 \mathrm{~g}$, inferior ao intervalo de 80 $150 \mathrm{meq} / 100 \mathrm{~g}$ de esmectitas puras. 


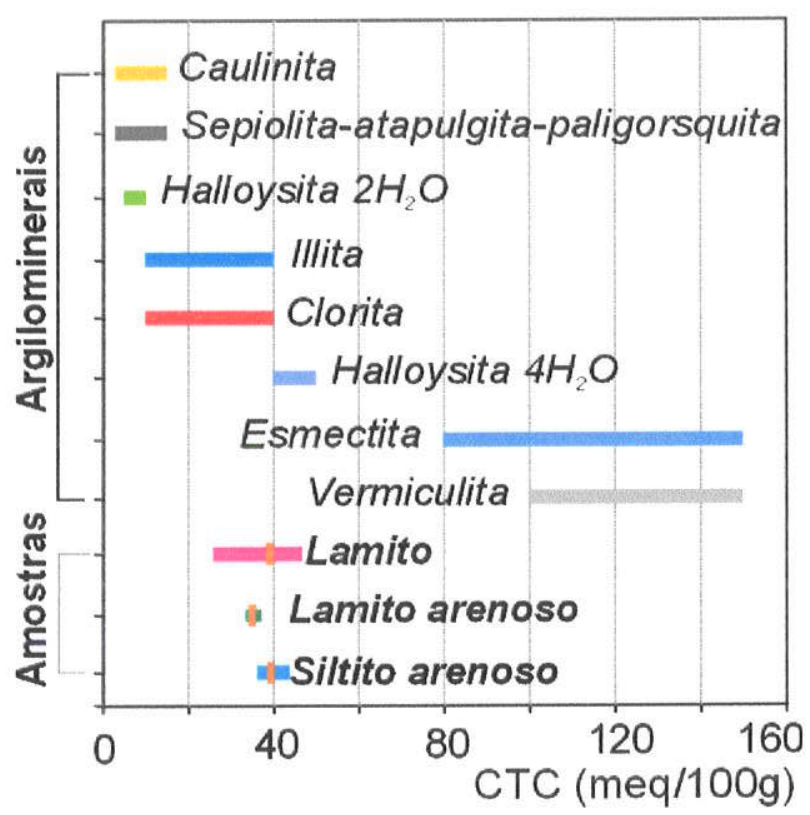

Figura 6.17: Capacidade de troca cationica dos argilominerais (Grim, 1968) comparada com as amostras de lamitos e siltitos (os pontos laranja representam as médias das amostras).

\subsection{Análises termodiferencial (ATD) e termogravimétrica (ATG).}

As transformações térmicas observadas nas análises termodiferencial e termogravimétrica auxiliaram as identificações mineralógicas, além de terem sido importantes na caracterização cerâmica, e imprescindíveis na determinação das temperaturas de ativação para os ensaios de atividade pozolânica.

Foram realizadas análises térmicas nas amostras C6V (lamito arenoso), C5A, C11 e C19 (lamitos), resultando em curvas termodiferencias e termogravimétricas, conforme apresentado nas Figuras 6.18 a 6.20 .

Segundo Guggenheim \& Groos (2001), as curvas termogravimétricas podem apresentar deflexões sutis que não são facilmente reconhecidas. Em busca dessas sutilezas determinase a derivada termogravimétrica - DTG (dm/dt - variação da massa em função da temperatura). Das quatro amostras analisadas, somente no termograma da amostra C6V foi observada uma pequena perda de massa relativa $(0,67 \%)$ na temperatura de $266^{\circ} \mathrm{C}$, possivelmente relacionada ainda à eliminação de água adsorvida. 


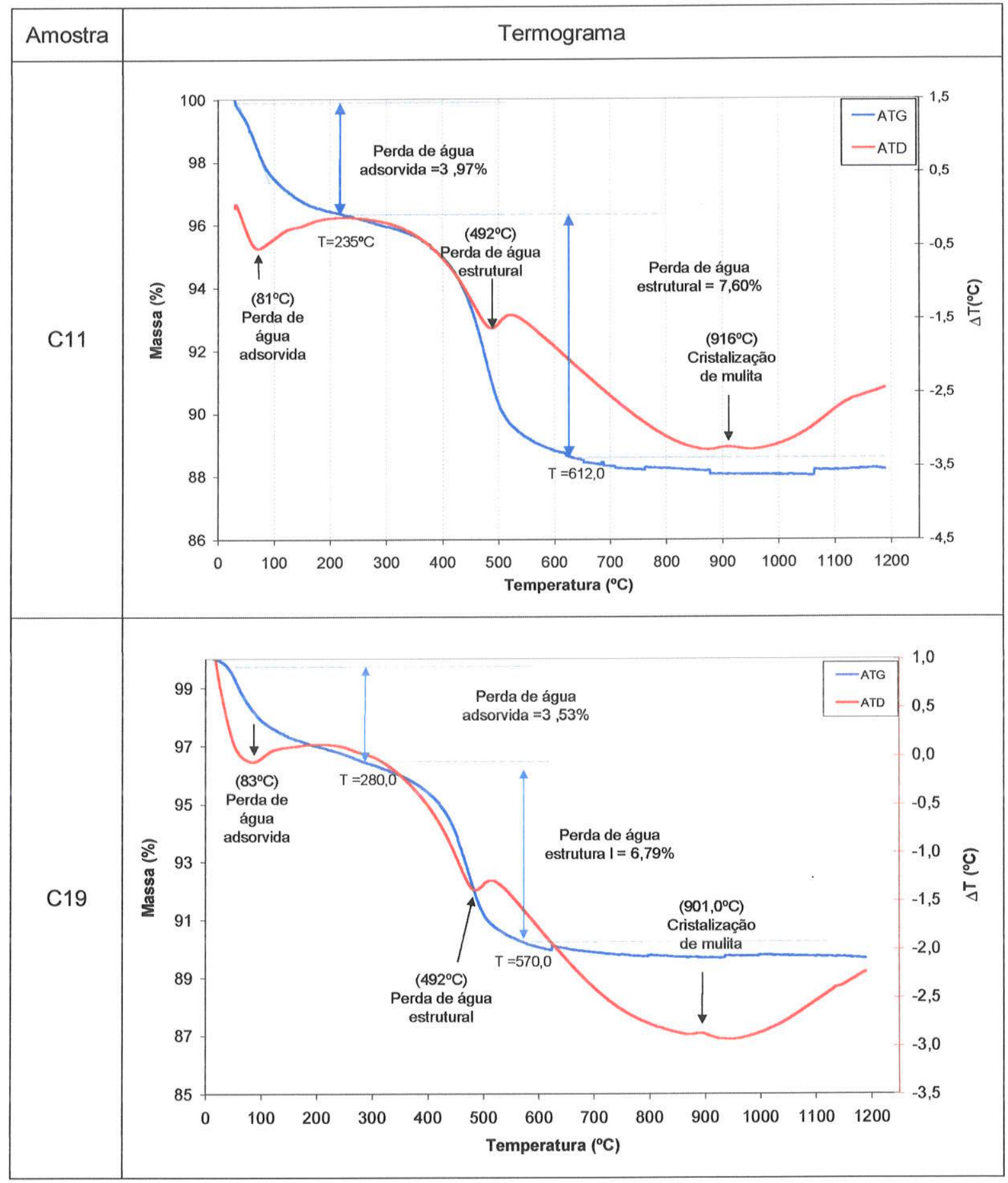

Figura 6.18: (a) e (b) Curvas de ATD e ATG para amostras de lamito C11 e C19 (tal qual). 


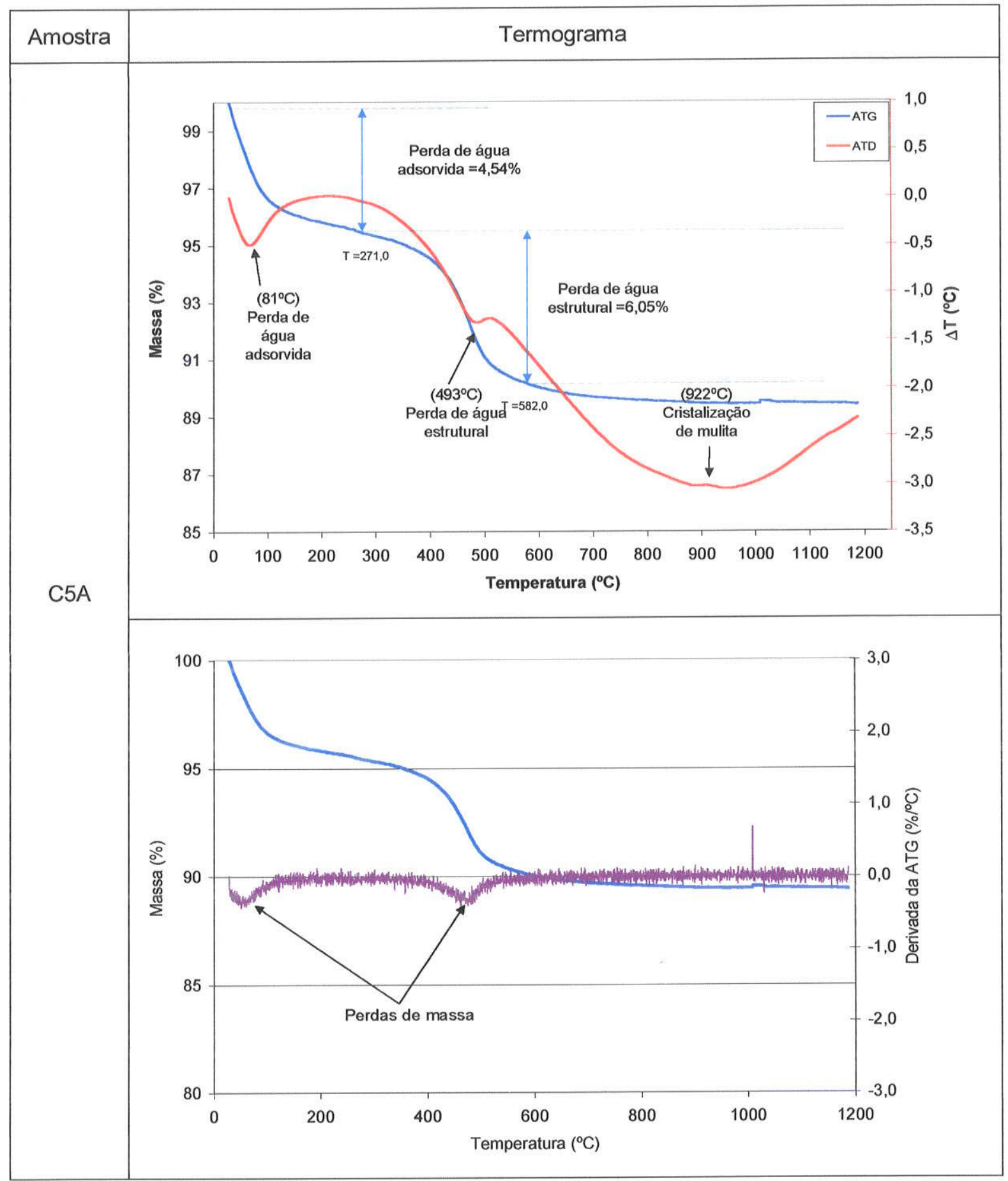

Figura 6.19: Curvas de ATD e ATG para amostra de lamito C5A (tal qual) e curva de DTG (derivada termogravimétrica). 


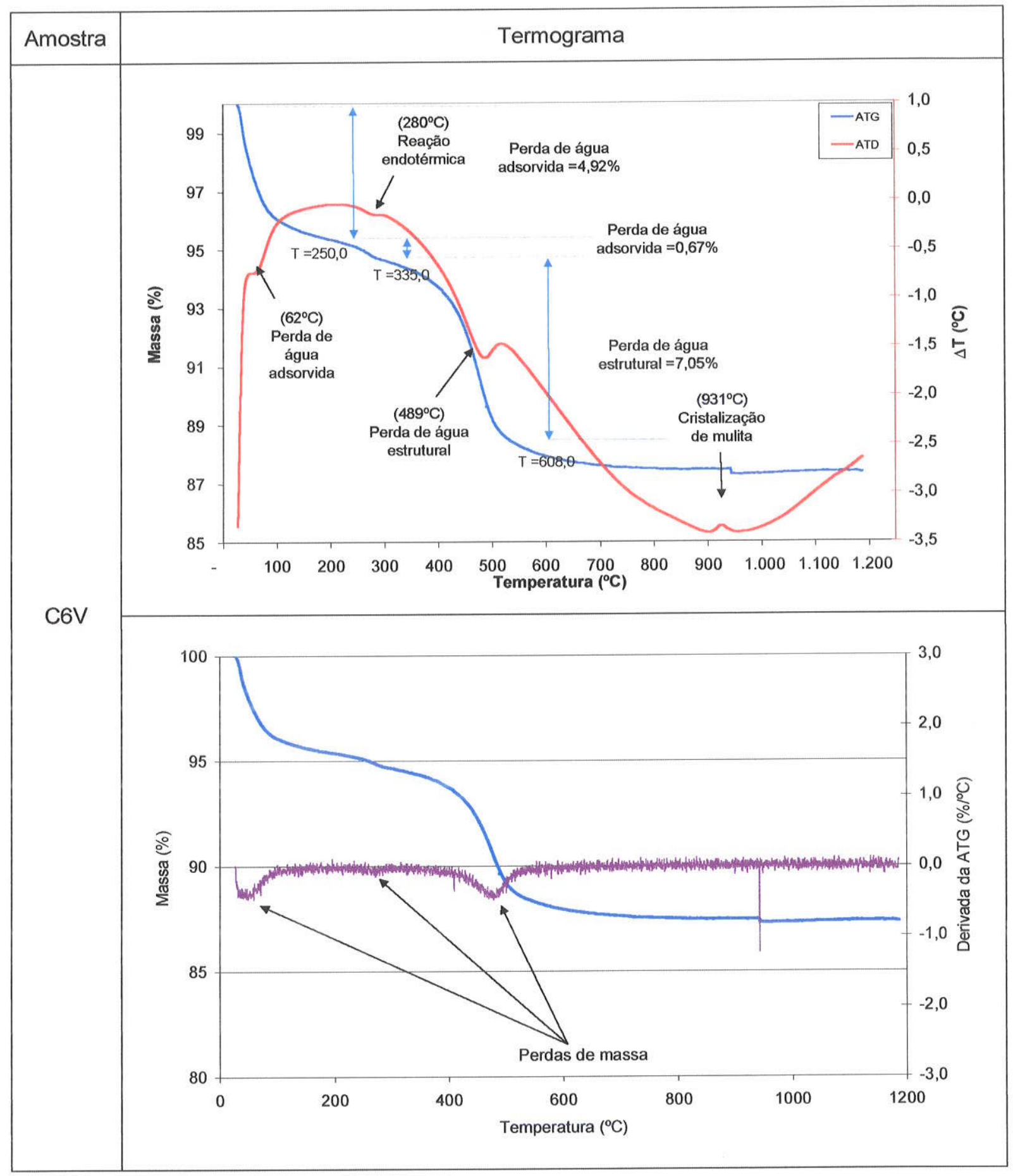

Figura 6.20: Curvas de ATD e ATG para amostra de lamito arenoso C6V (tal qual) e curva de DTG (derivada termogravimétrica).

A análise das curvas de ATD (análise termo diferencial) mostra que a eliminação da água adsorvida e coordenada por cátions trocáveis ocorreu em temperaturas inferiores à $100^{\circ} \mathrm{C}$, indicado pela posição da primeira deflexão endotérmica. Nessa primeira transformação foram perdidas 3 a $4 \%$ da massa inicial. 
A desidroxilação (eliminação de água estrutural - hidroxila) ocorreu por volta de $500^{\circ} \mathrm{C}$, com perdas de 6-7\% da massa, representada pelo segundo pico endotérmico intenso. Em temperatura próxima de $930^{\circ} \mathrm{C}$, iniciou-se a reorganização atômica, com nucleação de novas de fases estáveis à elevada temperatura (possivelmente mulita e cristobalita), observada pelo pico exotérmico na curva de ATD (Tabela 6.5).

Tabela 6.5: Temperaturas iniciais (To) e finais (Tc) para as transformações térmicas e variações de massa $(\Delta \%)$.

\begin{tabular}{|c|c|c|c|c|c|c|}
\hline \multirow{2}{*}{ Análise } & \multirow{2}{*}{ Amostra } & \multicolumn{3}{|c|}{ Lamito } & \multirow{2}{*}{$\begin{array}{c}\text { Lamito } \\
\text { arenoso } \\
\text { C6V }\end{array}$} & \multirow[b]{2}{*}{ Transformações } \\
\hline & & C5A & C11 & C19 & & \\
\hline \multirow{9}{*}{$\stackrel{0}{\stackrel{0}{<}}$} & To $\left({ }^{\circ} \mathrm{C}\right)$ & 28 & 30 & 14 & 28 & \multirow{3}{*}{$\begin{array}{l}\text { Eliminação de água adsorvida e } \\
\text { água coordenada aos cátions } \\
\text { trocáveis. }\end{array}$} \\
\hline & $\mathrm{Tc}\left({ }^{\circ} \mathrm{C}\right)$ & 271 & 235 & 280 & 250 & \\
\hline & $\Delta$ massa $(\%)$ & 4,54 & 3,97 & 3,53 & 4,92 & \\
\hline & To $\left({ }^{\circ} \mathrm{C}\right)$ & - & - & - & 250 & \multirow{3}{*}{ Eliminação de água adsorvida } \\
\hline & $\operatorname{Tc}\left({ }^{\circ} \mathrm{C}\right)$ & - & - & - & 335 & \\
\hline & $\Delta$ massa (\%) & - & - & - & 0,67 & \\
\hline & To $\left({ }^{\circ} \mathrm{C}\right)$ & 271 & 235 & 280 & 335 & \multirow{3}{*}{ Eliminação de água estrutural } \\
\hline & Tc $\left({ }^{\circ} \mathrm{C}\right)$ & 582 & 612 & 570 & 608 & \\
\hline & $\Delta$ massa $(\%)$ & 6,05 & 7,6 & 6,79 & 7,05 & \\
\hline \multirow{4}{*}{$\stackrel{0}{<}$} & & 81 & 81 & 82 & 82 & \multirow{3}{*}{ Perdas de água } \\
\hline & Reações & 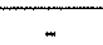 & . & - & 280 & \\
\hline & & 493 & 492 & 493 & 489 & \\
\hline & $\begin{array}{c}\text { Reação } \\
\text { exotérmica }\end{array}$ & 922 & 916 & 901 & 931 & Recristalização \\
\hline
\end{tabular}

Nas temperaturas de queima selecionadas para os ensaios cerâmicos (cerâmica estrutural $-950^{\circ} \mathrm{C}$ e de revestimento $-1100^{\circ} \mathrm{C}$ ) ocorreram transformações mineralógicas importantes, possivelmente com geração de novas fases cristalinas, incluindo mulita e também uma fase vítrea.

Para a aplicação como pozolanas, a temperatura de calcinação para ativação teria de ser superior a $550^{\circ} \mathrm{C}$, na qual se iniciou o colapso cristalino de parte dos argilominerais presentes, principalmente da caulinita. O limite superior seria definido por volta de $900^{\circ} \mathrm{C}$, antes da nucleação de mulita.

Comparativamente com dados apresentados por Smyktaz-Kloss (1974), o intervalo de 550 e $900^{\circ} \mathrm{C}$ representaria as transformações térmicas em caulinitas. Possivelmente, o início do desarranjo cristalino da esmectita e da illita deve ter ocorrido nesse intervalo, uma vez que em torno de $700^{\circ} \mathrm{C}$ seria iniciado a desidroxilação desses argilominerais. 


\subsection{Microscopia Eletrônica de Varredura}

Foram analisadas ao microscópio eletrônico de varredura 3 amostras tal qual (C6V, C11 e C19) e as respectivas frações $<2 \mu \mathrm{m}$, com a finalidade de reconhecer a morfologia dos argilominerais presentes.

Sant'Anna (1999) descreveu as esmectitas da Formação Resende, como formas onduladas de granulação fina, crescidas como agregados e também como placas de granulação grossa, ambos contendo $\mathrm{Si}, \mathrm{Al}, \mathrm{Mg}, \mathrm{K}, \mathrm{Ca}$ e Fe.

As imagens obtidas no MEV para as amostras C6V são apresentadas nas Pranchas 6.1; 6.2 e 6.3. Os argilominerais da amostra C6V em geral apresentaram-se com bordas irregulares e formas não euédricas. Não foi possível a diferenciação de hábito cristalino entre os argilominerais presentes (illita e caulinita). O espectro de EDS (c) sugeriu uma composição illítica para o ponto analisado, enquanto que (e) representaria o espectro de uma caulinita, dada a ausência de Mg e a relativa pequena quantidade de Fe presente.

As amostras C11 e C19 apresentaram Mg, Fe e K, além de Si e Al. Esses resultados refletiram as composições illíticas e esmectíticas das frações argilosas. De forma geral, as caulinitas apresentaram-se como cristais não euédricos de bordas irregulares, a esmectita, por sua vez, mostrou-se em finas placas de bordos irregulares. 

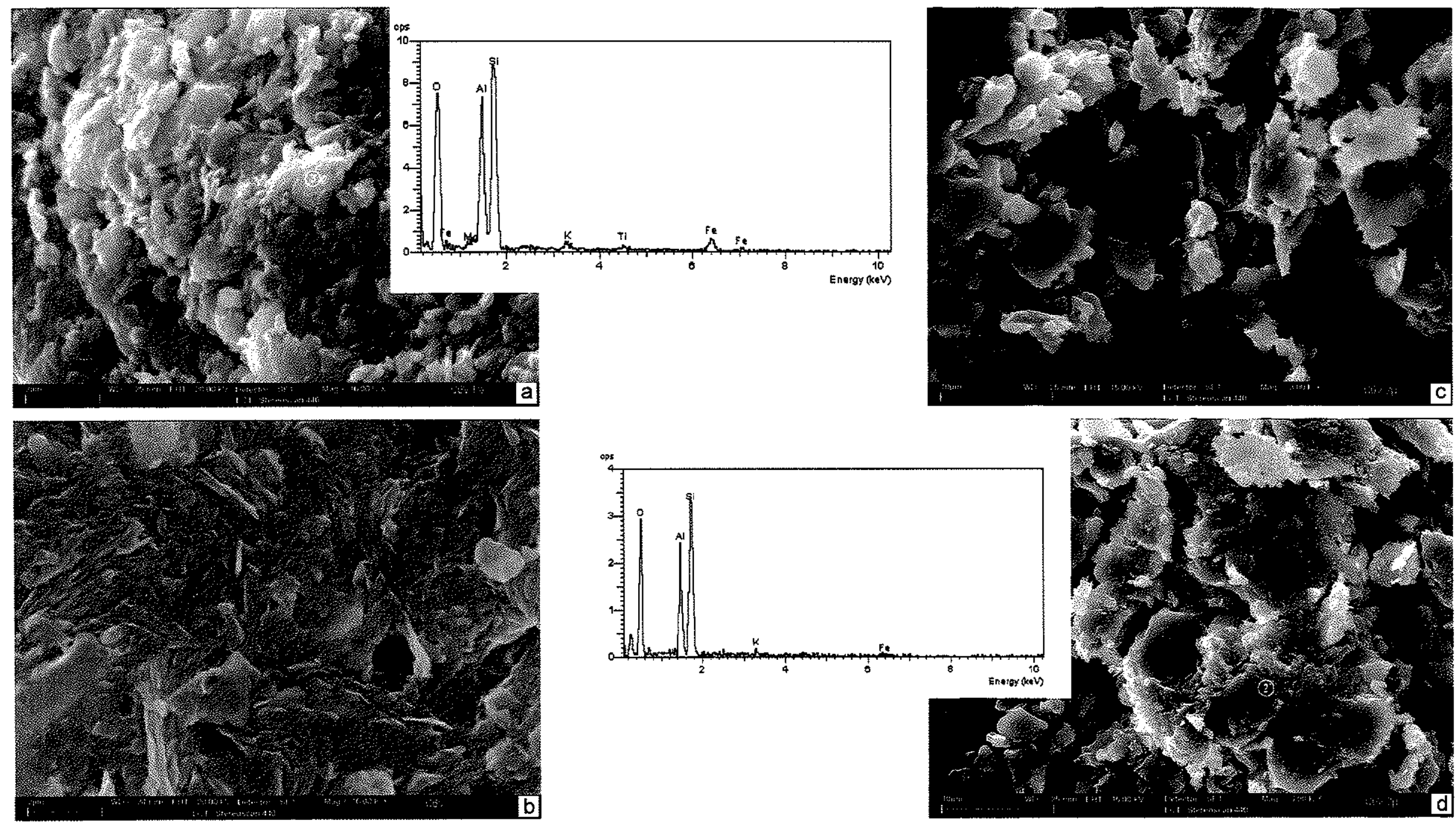

Prancha 6.3: Imagens ao microscópio eletrônico de varredura (MEV sinal de elétrons secundários) da amostra C6V tal qual e fração <2m: (a) aspecto geral da matriz argilosa e espectro de EDS mostrando composição ilíitica (?) na área circundada: (b) aspecto geral da matriz lamítica; (c) argilominerais da fração <2m; (d) argilominerais da fração $<2 \mathrm{~m}$ com espectro de EDS determinado na área circundada, mostrando a composição caulinítica. 

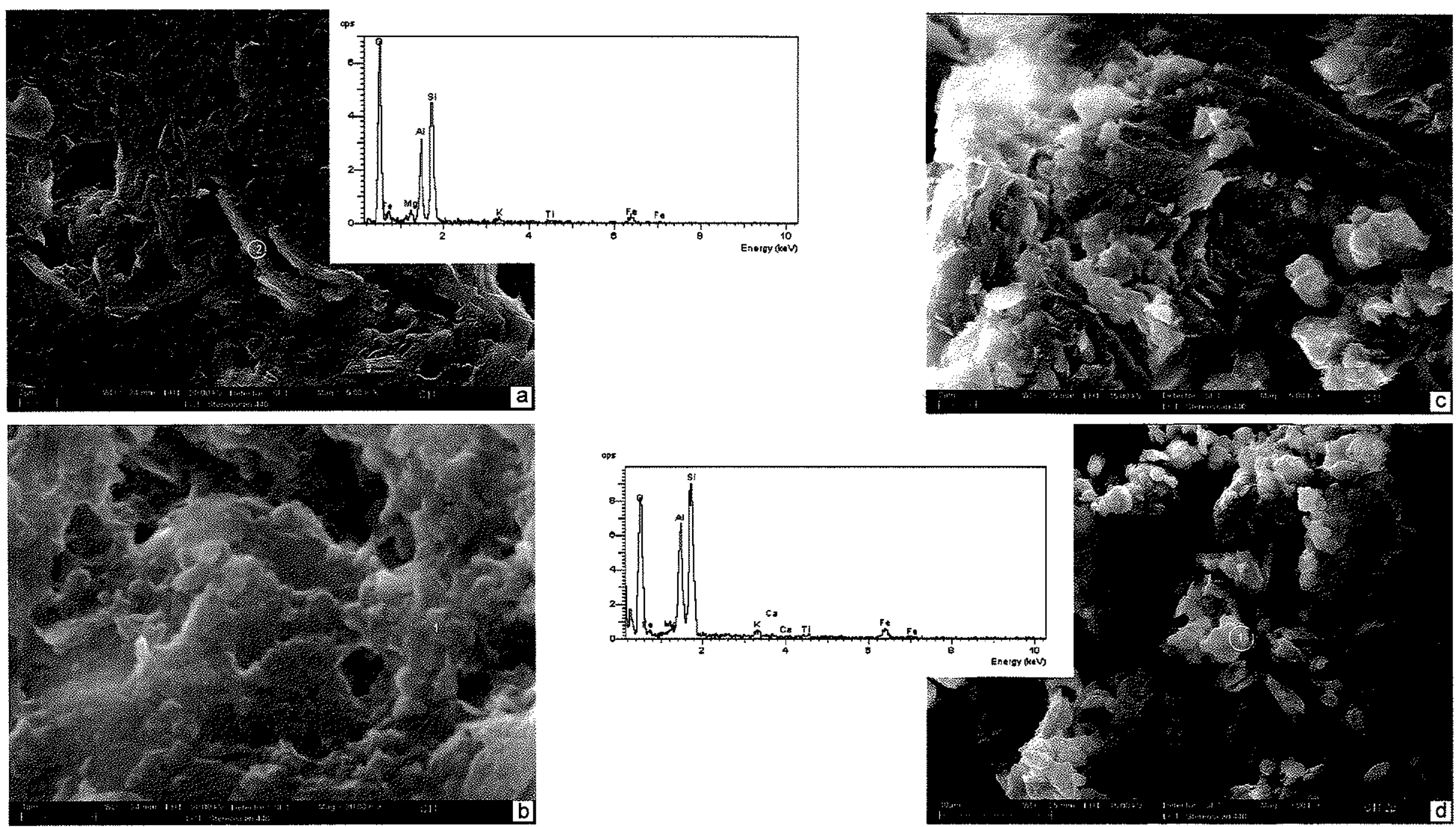

Prancha 6.4: Imagens ao microscópio eletrônico de varredura (MEV sinal de elétrons secundários) da amostra C11 tal qual e fração <2m: (a) aspecto geral da matriz argilosa e espectro de EDS mostrando composição illítica (?) na área circundada: (b) detalhe da matriz lamítica e espectro de EDS mostrando uma composição caulinítica; (c) aspecto geral dos argilominerais; (d) argilominerais da fração < $2 \mathrm{~m}$ com espectro de EDS determinado na área circundada, mostrando a composição esmectítica. 

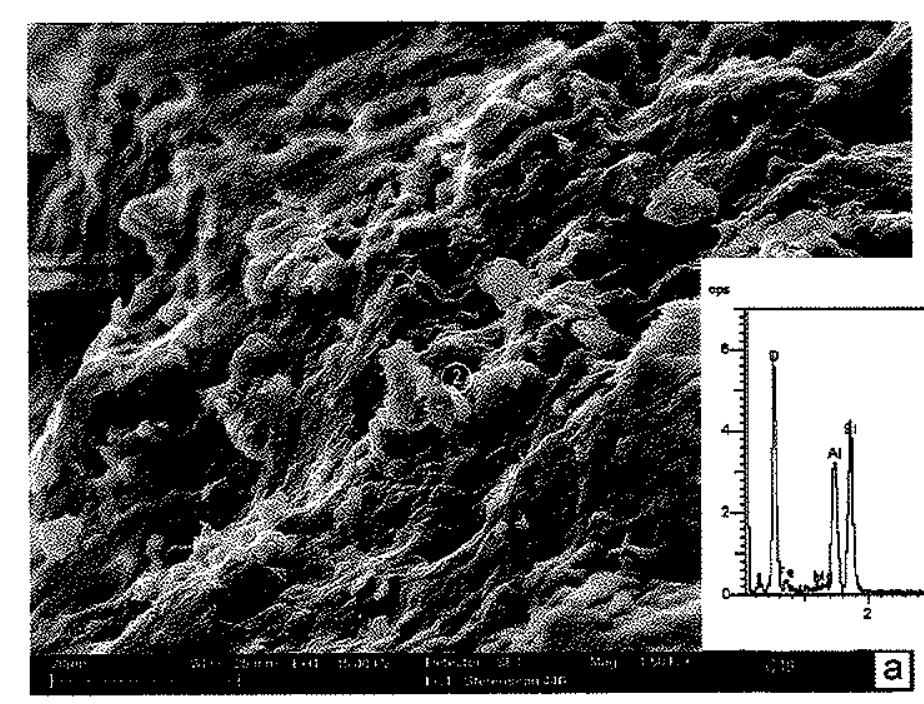
(ops

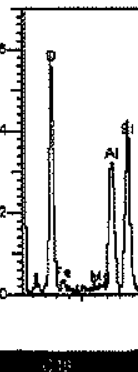

a

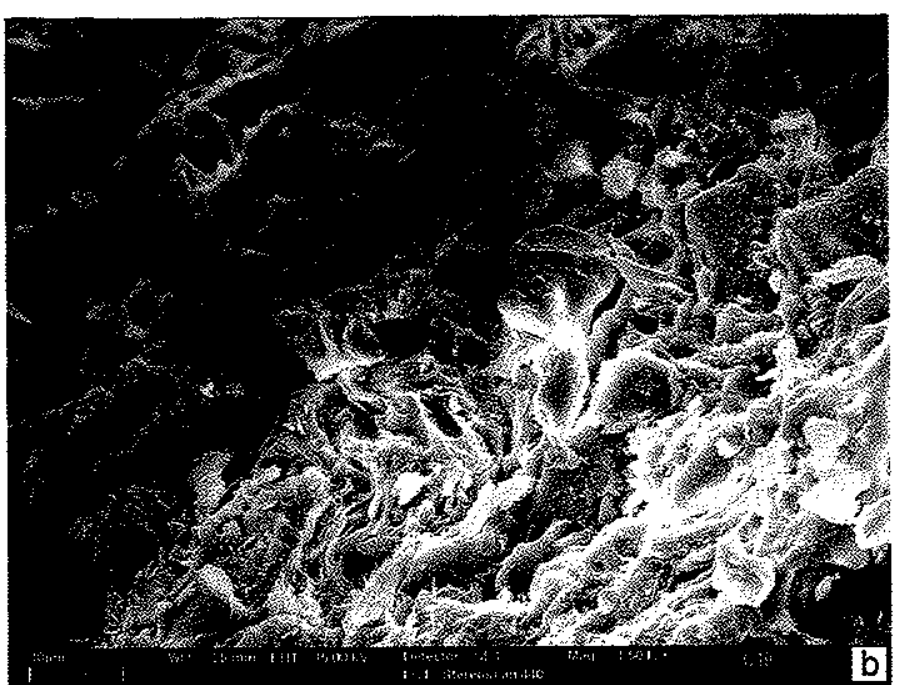

b

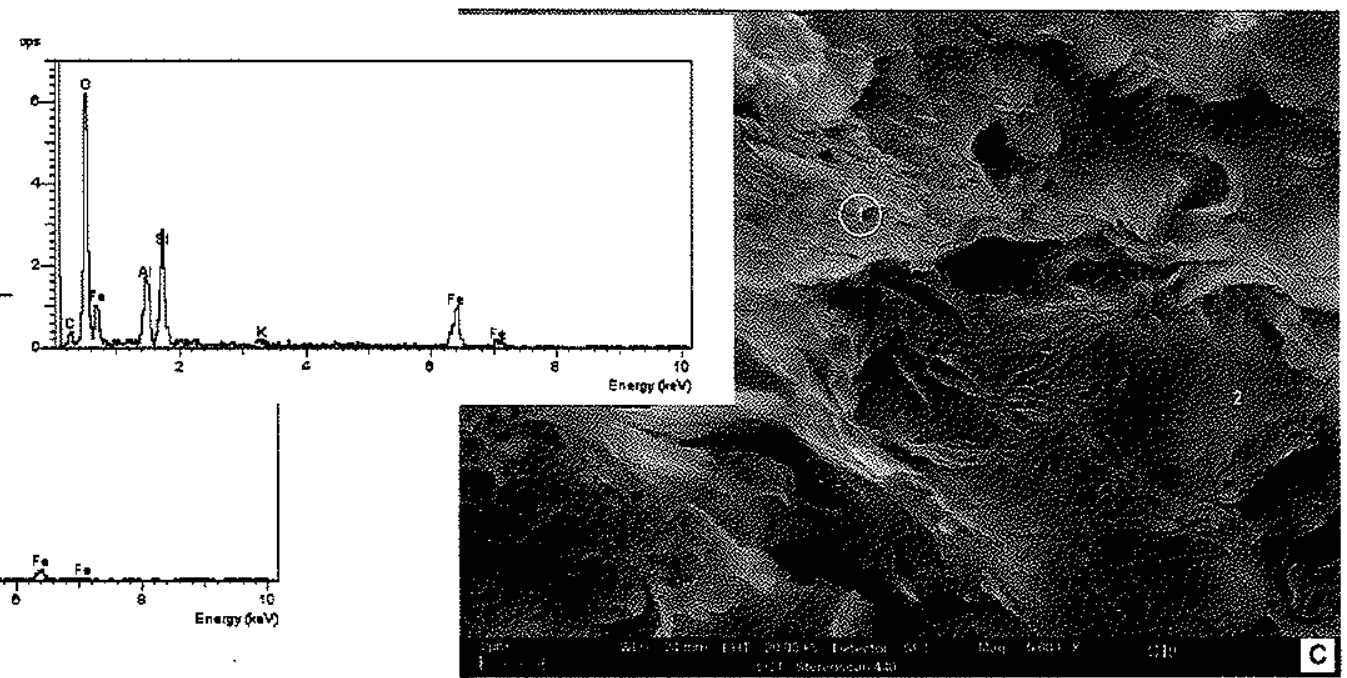

C

Prancha 6.5: Imagens ao microscópio eletrônico de varredura (MEV sinal de elétrons secundários) da amostra C19 tal qual: (a) aspecto geral da matriz argilosa e espectro de EDS mostrando composição esmectítica (?) na área circundada: (b) aspecto geral da matriz lamítica; (c) aspecto geral da matriz lamítica e espectro de EDS mostrando uma composição caulinítica; (d) argilominerais comespectro de EDS determinado na área circundada, mostrando a composição esmectítica. 


\subsection{Quantificação das fases mineralógicas}

A quantificação das fases mineralógicas foi realizada a partir da integração de informações obtidas na caracterização tecnológica.

A assembléia mineralógica é formada por esmectita (beidellita), caulinita, mica (illita?), quartzo e acessórios (goethita, feldspato, etc.). Desses minerais, apenas o quartzo $\left(\mathrm{SiO}_{2}\right)$ e a caulinita $\left(\mathrm{Al}_{2} \mathrm{O}_{3} \cdot 2 \mathrm{SiO}_{2} \cdot 2 \mathrm{H}_{2} \mathrm{O}\right)$ apresentam fórmulas químicas definidas, muito embora a segunda também possa apresentar variações. A esmectita e a illita apresentam composições químicas muito variáveis.

Se houvesse apenas uma espécie de argilomineral, a quantificação poderia se basear em perdas de massas obtidas de curvas termogravimétricas, como realizado por Zampieri (1989) em amostras cauliníticas. Porém o caráter poliminerálico não permitiu o uso dessa ferramenta.

A quantificação mineralógica de argilominerais por difração de raios $X$ é bastante complexa, e requer um conjunto de procedimentos especiais de preparação, aquisição e tratamento de dados, além de fornecer resultados com um nível de confiança pequeno. Além desses fatores, a presença de argilominerais de baixa cristalinidade, como a esmectita presente nas amostras, não permitiu a interpretação quantitativa com confiabilidade.

Por essas dificuldades, buscou-se integrar algumas das informações obtidas a fim de se determinar, mesmo com menor confiabilidade, a composição mineralógica das amostras. A quantificação foi realizada por estequiometria a partir da integração de duas bases de informação: distribuição granulométrica e composições químicas dos argilominerais obtidas em literatura.

O teor de quartzo das amostras foi definido pela massa de material com granulometria superior à $44 \mu \mathrm{m}$, desde que essa fração é basicamente formada por quartzo, como visto em estereomicroscópio. A utilização desse critério granulométrico foi reforçada pelos resultados de DRX obtidos por Sant'Anna (1999), nos quais o quartzo não foi identificado na fração $<31 \mu \mathrm{m}$, em lamitos da Formação Resende.

Para a illita e a caulinita foram utilizadas as composições quimicas, compiladas da literatura, conforme indicado na Tabela 6.6. 
Tabela 6.6: Composições químicas illita e caulinita.

\begin{tabular}{|c|c|c|c|c|c|c|c|}
\hline \multirow{2}{*}{ Mineral } & \multirow{2}{*}{ Origem } & $\mathrm{SiO}_{2}$ & $\mathrm{Al}_{2} \mathrm{O}_{3}$ & $\mathrm{Fe}_{2} \mathrm{O}_{3}$ & MgO & $\mathrm{K}_{2} \mathrm{O}$ & $\mathrm{H}_{2} \mathrm{O}$ \\
\hline & & \multicolumn{6}{|c|}{$\%$ (em peso) } \\
\hline \multirow{4}{*}{ illita } & Alexander County, Illinois ${ }^{(1)}$ & 52,23 & 25,85 & 4,04 & 2,69 & 6,56 & 8,63 \\
\hline & Geoschwitz, Germany ${ }^{(1)}$ & 51,65 & 21,67 & 6,20 & 3,60 & 7,98 & 8,90 \\
\hline & NP548 ${ }^{(2)}$ & 45,70 & 35,10 & 1,14 & 0,35 & 7,95 & 9,76 \\
\hline & Média & 49,86 & 27,54 & 3,79 & 2,21 & 7,50 & 9,10 \\
\hline caulinita & $\mathrm{Al}_{2} \mathrm{O}_{3} .2 \mathrm{SiO}_{2} .2 \mathrm{H}_{2} \mathrm{O}$ & 46,51 & 39,53 & & & & 13,95 \\
\hline
\end{tabular}

A composição da esmectita foi extraída de Sant'Anna (1999), obtida para uma amostra de lamito da Formação Resende da região de Mogi das Cruzes (amostra tb-49). Como a autora expressou os dados em fórmula anidra, as demais composições foram igualmente padronizadas, conforme a Tabela 6.7 .

Tabela 6.7: Composição química anidra para esmectita, illita e caulinita.

\begin{tabular}{|c|c|c|c|c|c|}
\hline \multirow{2}{*}{ Argilomineral } & $\mathrm{SiO}_{2}$ & $\mathrm{Al}_{2} \mathrm{O}_{3}$ & $\mathrm{Fe}_{2} \mathrm{O}_{3}$ & $\mathrm{MgO}$ & $\mathrm{K}_{2} \mathrm{O}$ \\
\cline { 2 - 6 } & \multicolumn{5}{|c|}{$\%$ (em peso) } \\
\hline Esmectita & 64,73 & 23,40 & 7,41 & 1,02 & 2,07 \\
\hline IIlita & 54,05 & 45,95 & & & \\
\hline Caulinita & 54,85 & 30,30 & 4,17 & 2,43 & 8,24 \\
\hline
\end{tabular}

Para a quantificação mineralógica foram, então, empregadas composições químicas anidras das amostras, tomando-se como base para os cálculos os óxidos $\mathrm{SiO}_{2}, \mathrm{Al}_{2} \mathrm{O}_{3} \mathrm{e}$ $\mathrm{K}_{2} \mathrm{O}$. Os demais óxidos não puderam ser utilizados devido à pequena proporção nas amostras, o que poderia conduzir a erros. Embora $\circ \quad \mathrm{Fe}_{2} \mathrm{O}_{3}$ apresentasse teores elevados, os dados não foram assumidos nos cálculos, uma vez que poderiam existir tanto em estruturas de argilominerais como na forma de óxidos de ferro amorfos. Os dados utilizados são apresentados na Tabela 6.8. 
Tabela 6.8: Composição química anidra dos óxidos $\mathrm{SiO}_{2 \text { total, }} \mathrm{SiO}_{2}$ livre e $\mathrm{SiO}_{2}$ ligado à estrutura de argilominerais, $\mathrm{Al}_{2} \mathrm{O}_{3}$ e $\mathrm{K}_{2} \mathrm{O}$.

\begin{tabular}{|c|c|c|c|c|c|}
\hline \multirow[t]{2}{*}{ Amostra } & $\mathrm{SiO}_{2}$ total & $\begin{array}{c}\mathrm{SiO}_{2} \text { livre } \\
\text { fração }>44 \mu \mathrm{m}\end{array}$ & $\begin{array}{c}\mathrm{SiO}_{2 \text { estrutura de }} \\
\text { argllominerais } \\
\left(\mathrm{SiO}_{2 \text { total }}-\mathrm{SiO}_{2 \text { livre }}\right)\end{array}$ & $\mathrm{Al}_{2} \mathrm{O}_{3}$ & $\mathrm{~K}_{2} \mathrm{O}$ \\
\hline & \multicolumn{5}{|c|}{ (\% em peso) } \\
\hline C2S & 65,97 & 21,68 & 44,29 & 24,12 & 1,99 \\
\hline C4A & 62,09 & 7,87 & 54,22 & 25,79 & 2,40 \\
\hline C4B & 63,04 & 8,86 & 54,18 & 24,88 & 2,84 \\
\hline C5A & 59,16 & 5,24 & 53,92 & 27,45 & 2,53 \\
\hline C5B & 72,57 & 25,99 & 46,58 & 18,40 & 2,65 \\
\hline $\mathrm{C6V}$ & 57,63 & 14,98 & 42,65 & 29,96 & 1,87 \\
\hline C11A & 58,06 & 1,92 & 56,14 & 29,95 & 2,35 \\
\hline C11B & 57,43 & 0,86 & 56,57 & 29,87 & 2,11 \\
\hline C11C & 58,08 & 0,55 & 57,53 & 28,20 & 2,20 \\
\hline C11D & 56,82 & 0,97 & 55,85 & 30,26 & 1,85 \\
\hline C11E & 56,83 & 0,56 & 56,27 & 30,81 & 1,85 \\
\hline C11F & 56,77 & 1,15 & 55,62 & 30,87 & 1,85 \\
\hline C13A & 78,17 & 50,70 & 27,47 & 15,01 & 3,19 \\
\hline C13B & 55,76 & 1,27 & 54,49 & 29,19 & 2,13 \\
\hline C18A & 56,30 & 1,67 & 54,63 & 28,31 & 2,17 \\
\hline C19AB & 58,55 & 3,33 & 55,22 & 28,13 & 2,06 \\
\hline C19CD & 58,32 & 3,76 & 54,56 & 28,26 & 2,14 \\
\hline
\end{tabular}

Da integração dessas informações foi então realizada a quantificação mineralógica, cujo resultado é apresentado na Tabela 6.9 .

Os lamitos mantiveram a tendência de homogeneidade composicional observada na distribuição granulométrica, composição química, etc.. A esmectita constituiu cerca de $49 \%$ das amostras de lamitos analisadas, enquanto que a caulinita representou $29 \%$. A illita apresentou-se em proporções médias de $14 \%$.

A amostra de lamito arenoso, C6V, mostrou-se mais caulinitica que a C2S. Apesar da esmectita não ter sido identificada em difratogramas de raios $X$ na amostra $C 6 V$, foi indicada pelos cálculos estequiométricos. Possivelmente, essa esmectita deve compor interestratificados com a illita.

Os siltitos arenosos C4A e C5B apresentaram composições esmectíticas, diferindo da amostra $\mathrm{C} 13 \mathrm{~A}$, que é illítica e quartzosa. Porém, o número reduzido de amostras desses litotipos não permitiu avaliar devidamente as variações entre as composições encontradas. 
Tabela 6.9: Resultados de quantificação mineralógica para as amostras.

\begin{tabular}{|c|c|c|c|c|c|c|c|}
\hline Amostra & Esmectita & Caulinita & Illita & $\begin{array}{c}\text { Argilominerais totais } \\
(\% \text { em peso })\end{array}$ & Quartzo & Outros & Total \\
\hline C4A & 54 & 20 & 16 & 89 & 8 & 3 & 97 \\
\hline $\mathrm{C} 5 \mathrm{~A}$ & 46 & 26 & 19 & 90 & 5 & 4 & 96 \\
\hline C11A & 45 & 33 & 17 & 95 & 2 & 3 & 97 \\
\hline C11B & 49 & 33 & 13 & 95 & 1 & 4 & 96 \\
\hline $\mathrm{C} 11 \mathrm{C}$ & 57 & 25 & 12 & 95 & 1 & 5 & 95 \\
\hline C11D & 48 & 36 & 10 & 94 & 1 & 5 & 95 \\
\hline $\mathrm{C} 11 \mathrm{E}$ & 47 & 37 & 11 & 95 & 1 & 5 & 95 \\
\hline $\mathrm{C} 11 \mathrm{~F}$ & 45 & 38 & 11 & 94 & 1 & 5 & 95 \\
\hline Média C11 & 48 & 34 & 13 & 94 & 1 & 5 & 95 \\
\hline C13B & 45 & 33 & 15 & 92 & 1 & 7 & 93 \\
\hline C18A & 48 & 29 & 14 & 91 & 2 & 7 & 93 \\
\hline C19AB & 52 & 28 & 12 & 92 & 3 & 5 & 95 \\
\hline C19CD & 48 & 29 & 14 & 91 & 4 & 5 & 95 \\
\hline Média C19 & 50 & 29 & 13 & 91 & 4 & 5 & 95 \\
\hline Média Lamito & 49 & 30 & 14 & 93 & 2 & 5 & 95 \\
\hline
\end{tabular}

\begin{tabular}{|c|c|c|c|c|c|c|}
\hline C2S & 32 & 27 & 16 & 75 & 22 & 3 \\
\hline C6V & 6 & 50 & 21 & 77 & 15 \\
\hline Média Lamito arenoso & $\mathbf{1 9}$ & $\mathbf{3 9}$ & $\mathbf{1 9}$ & $\mathbf{7 6}$ & $\mathbf{9}$ & $\mathbf{3}$ \\
\hline
\end{tabular}

\begin{tabular}{|c|c|c|c|c|c|c|c|}
\hline C4B & 53 & 15 & 21 & 89 & 9 & 2 & 98 \\
\hline $\mathrm{C} 5 \mathrm{~B}$ & 55 & 2 & 18 & 75 & 26 & 0 & 100 \\
\hline $\mathrm{C} 13 \mathrm{~A}$ & 1 & 10 & 38 & 50 & 51 & 0 & 100 \\
\hline Média siltito arenoso & 37 & 9 & 26 & 71 & 29 & 2 & 99 \\
\hline
\end{tabular}




\section{CAPITULO VII - RESULTADOS DOS ENSAIOS DE APLICAÇÃO}

\section{ENSAIOS DE APLICAÇÃO}

Para os ensaios específicos buscou-se avaliar a potencialidade de aplicação dos materiais de estudo, frente às suas características naturais e variabilidade.

\subsection{Ensaios Cerâmicos}

Os ensaios cerâmicos expeditos, feitos com o objetivo de avaliar a aplicabilidade dos materiais em cerâmica estrutural e cerâmica de revestimento, compreenderam, como detalhado no Capítulo IV, determinação das propriedades plásticas de amostras naturais e ensaios físicos pré e pós queima, nas temperaturas de 950 e $1100^{\circ} \mathrm{C}$, em corpos-de-prova prensados.

As oito amostras submetidas aos ensaios cerâmicos são relacionadas na Tabela 7.1.

Tabela 7.1: Amostras selecionadas para os ensaios cerâmicos.

\begin{tabular}{|c|c|}
\hline Material & Amostra \\
\hline \multirow{4}{*}{ Lamito } & $\mathrm{C} 4 \mathrm{~A}$ \\
\cline { 2 - 2 } & $\mathrm{C} 5 \mathrm{~A}$ \\
\cline { 2 - 2 } & $\mathrm{C} 11$ \\
\cline { 2 - 2 } & $\mathrm{C} 13 \mathrm{~B}$ \\
\cline { 2 - 2 } & $\mathrm{C} 19$ \\
\hline \multirow{2}{*}{ Lamito arenoso } & $\mathrm{C} 2 \mathrm{~S}$ \\
\hline \multirow{2}{*}{ Siltito arenoso } & $\mathrm{C} 6 \mathrm{~V}$ \\
\cline { 2 - 2 } & $\mathrm{C} 4 \mathrm{~B}$ \\
\hline
\end{tabular}

\subsubsection{Limites de Atteberg - Limites de Liquidez e Plasticidade}

Um material se encontra no estado líquido quando se apresenta como um fluido denso. $\AA$ medida em que ocorre evaporação da água, o material endurece e perde a capacidade de fluir (Limite de Liquidez - LL), mantendo porém a capacidade de ser moldado e conservar a sua forma. Com a perda contínua de umidade, o estado plástico gradativamente é alterado até o momento em que o material se desmancha ao ser trabalhado (Limite de Plasticidade LP), caracterizando o estado semi sólido. Continuando a secagem, ocorre a passagem gradual para o estado sólido (Limite de Contração - LC). $O$ índice de plasticidade (IP), determinado pela diferença entre os limites de liquidez e plasticidade, define a zona em que 
o material encontra-se no estado plástico. Quanto mais elevado o IP maior é a plasticidade do material (Caputo, 1975) (Figura 7.1).

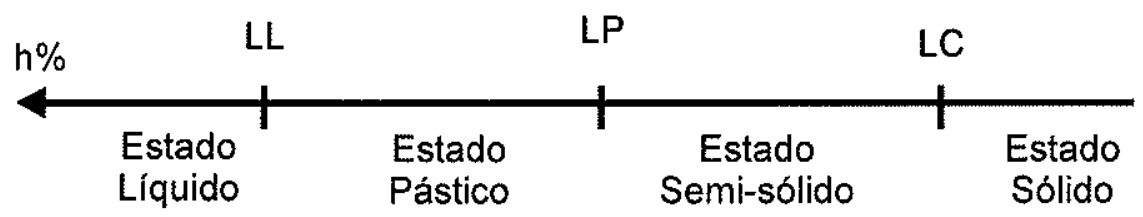

Figura 7.1: Estados de consistência e suas fronteiras (adaptado de Caputo, 1975).

Nos segmentos cerâmicos abordados, as propriedades plásticas são importantes para previsão do comportamento dos materiais em meio aquoso, tanto no aspecto tecnológico como no econômico. A quantidade de água necessária para obter a trabalhabilidade de massas cerâmicas, o tempo e a energia gastos na secagem, e a qualidade das peças são influenciados pelas propriedades plásticas das matérias-primas.

Em cerâmica vermelha, a conformação das peças ocorre com as matérias-primas no estado plástico. Numa situação ideal, esse estado é atingido com o limite de plasticidade entre 15 e $25 \%$ (Bain, 1986) e limite de liquidez entre 45 e 55\% (Gippini, 1969), que resulta em índice de plasticidade próximo a $30 \%$.

Os limites de Atteberg ou índices de consistência (LL, LP e IP) obtidos para as amostras estudadas são apresentados na Tabela 7.2.

Tabela 7.2: Resultados obtidos para os limites de liquidez e plasticidade, e índice de plasticidade.

\begin{tabular}{|c|c|c|c|c|}
\hline Material & Amostra & $\begin{array}{l}\text { Limite de } \\
\text { liquidez }(\%)\end{array}$ & $\begin{array}{c}\text { Limite de } \\
\text { Plasticidade(\%) }\end{array}$ & $\begin{array}{c}\text { Indice de } \\
\text { Plasticidade(\%) }\end{array}$ \\
\hline \multirow{7}{*}{$\frac{O}{E}$} & C11 & 105 & 39 & 66 \\
\hline & C13B & 74 & 40 & 34 \\
\hline & C18A & 69 & 39 & 30 \\
\hline & C19 & 91 & 46 & 45 \\
\hline & Média & 85 & 41 & 44 \\
\hline & Desvio Padrão & \pm 16 & \pm 3 & \pm 16 \\
\hline & Desvio Relativo (\%) & 19 & 8 & 37 \\
\hline & & & & \\
\hline \multirow{5}{*}{ 욤: } & $\mathrm{C} 2 \mathrm{~S}$ & 60 & 35 & 25 \\
\hline & $\mathrm{C} 6 \mathrm{~V}$ & 76 & 38 & 38 \\
\hline & Média & 68 & 36 & 32 \\
\hline & Desvio Padrão & \pm 11 & \pm 2 & \pm 9 \\
\hline & Desvio Relativo (\%) & 17 & 6 & 29 \\
\hline & & & & \\
\hline \multirow{5}{*}{ o } & $\mathrm{C} 4 \mathrm{~B}$ & 63 & 32 & 32 \\
\hline & $\mathrm{C} 5 \mathrm{~B}$ & 49 & 29 & 20 \\
\hline & Média & 56 & 30 & 26 \\
\hline & Desvio Padrão & \pm 10 & \pm 2 & \pm 8 \\
\hline & Desvio Relativo (\%) & 18 & 7 & 33 \\
\hline
\end{tabular}


Os Limites de Atteberg foram avaliados de duas formas. Na primeira, foi feita a comparação gráfica entre o Índice de Plasticidade x Limite de Liquidez, utilizando-se do Diagrama de Casagrande, modificado por Gippini (1969). Na segunda, utilizou-se o diagrama de Bain (1986), na qual são confrontados o Índice de Plasticidade e o Limite de Plasticidade.

No Diagrama de Casagrande (Gippini, 1969), a reta a $45^{\circ}$ é uma representação teórica de materiais que apresentariam índice de plasticidade igual ao limite de liquidez; a reta $\mathrm{IP}=0,90$ é o limite superior experimental para argilas naturais com limite de liquidez inferior a 8 (LL < 8); a reta $I P=0,73$, também chamada de Linha $A$, separa argilas essencialmente inorgânicas de argilas com conteúdos de colóides orgânicos; a reta $L L=50$, também chamada de Linha $B$ ( $L L<20)$, é uma linha convencional que separa argilas com elevada plasticidade à direita, daquelas que têm uma plasticidade média e baixa à esquerda (Figura 7.2).

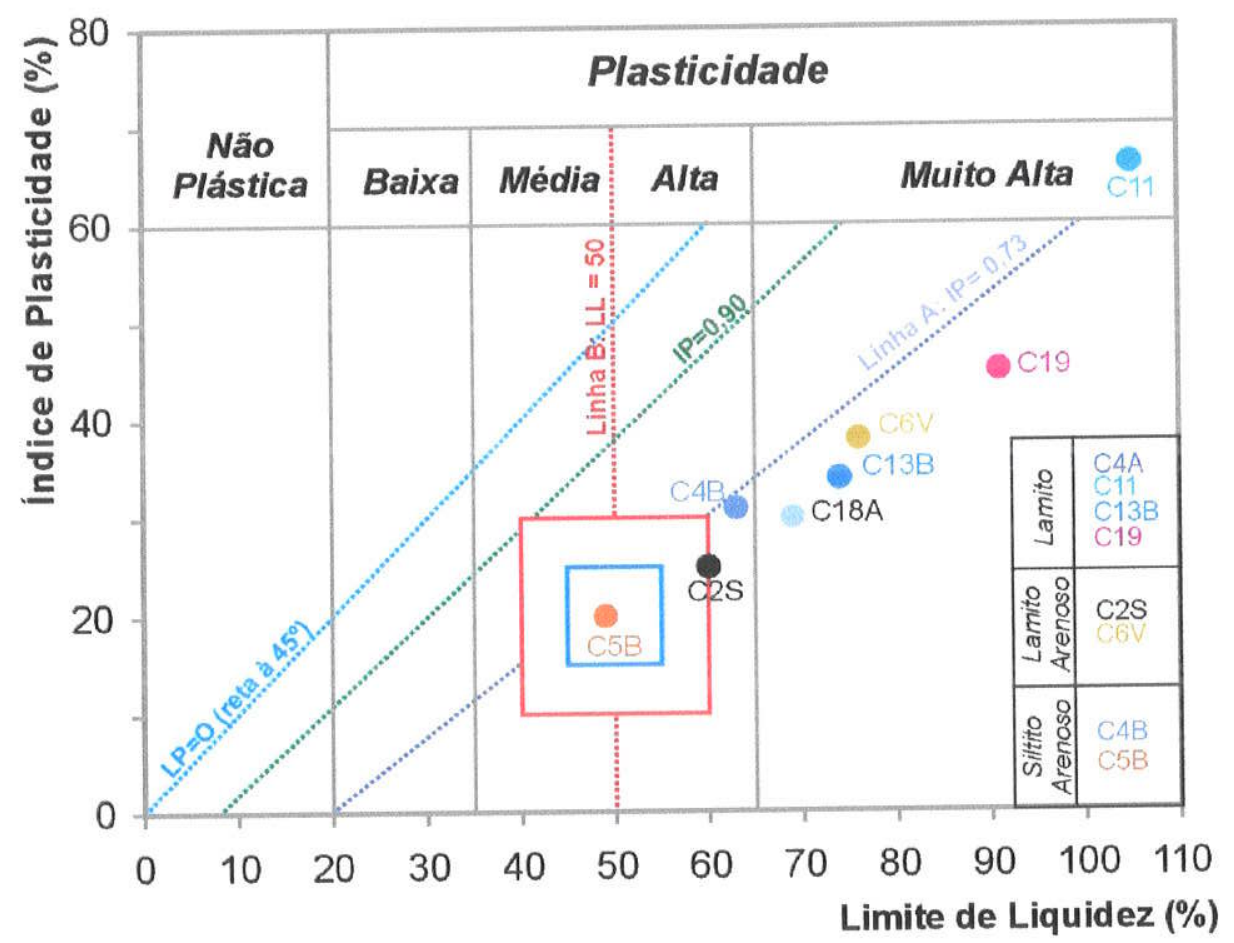

Figura 7.2: Diagrama de Casagrande, segundo Gippini (1969).

Matérias-primas cujas características plásticas enquadram-se no campo limitado em vermelho apresentam propriedades de moldagem e secagem aceitáveis. Idealmente as melhores condições seriam encontradas no campo limitado em azul.

Pôde-se notar no Diagrama de Casagrande, segundo Gippini (1969), que as propriedades obtidas refletiram, para a maioria das amostras, as características granulométricas das rochas analisadas. Em geral, os lamitos apresentaram maior plasticidade que os siltitos arenosos. 
Existem outros fatores além da granulometria do material que poderiam ter influenciado nas propriedades plásticas, como a natureza dos argilominerais e os respectivos graus de cristalinidade. A presença de esmectita, principalmente de baixa cristalinidade, pode ter contribuído para os altos índices de plasticidade obtidos.

Das 8 amostras analisadas somente duas (C5B e C2S), ambas de siltitos arenosos, apresentaram as propriedades plásticas adequadas à aplicação cerâmica, considerandose a confecção de peças extrudadas. As demais apresentaram índices de plasticidade bastante elevados, acima de 30\%, que atuariam negativamente durante a secagem, devido à elevada retração, resultando em deformações e trincas nas peças.

No diagrama de Bain (1986) são definidos campos para os índices de plasticidade e limites de plasticidade mais adequados para os diversos processos de conformação de massas cerâmicas, como indicado na Figura 7.3 na qual foram lançados os resultados obtidos neste estudo. Pôde-se perceber que os limites de plasticidade obtidos pouco variaram, porém verificou-se uma certa dependência entre os índices de plasticidade e as respectivas composições granulométricas/mineralógicas. Amostras mais argilosas (C11, por exemplo) apresentaram maiores índices de plasticidade que aquelas mais arenosas ( $C 4 \mathrm{~B}$, por exemplo).

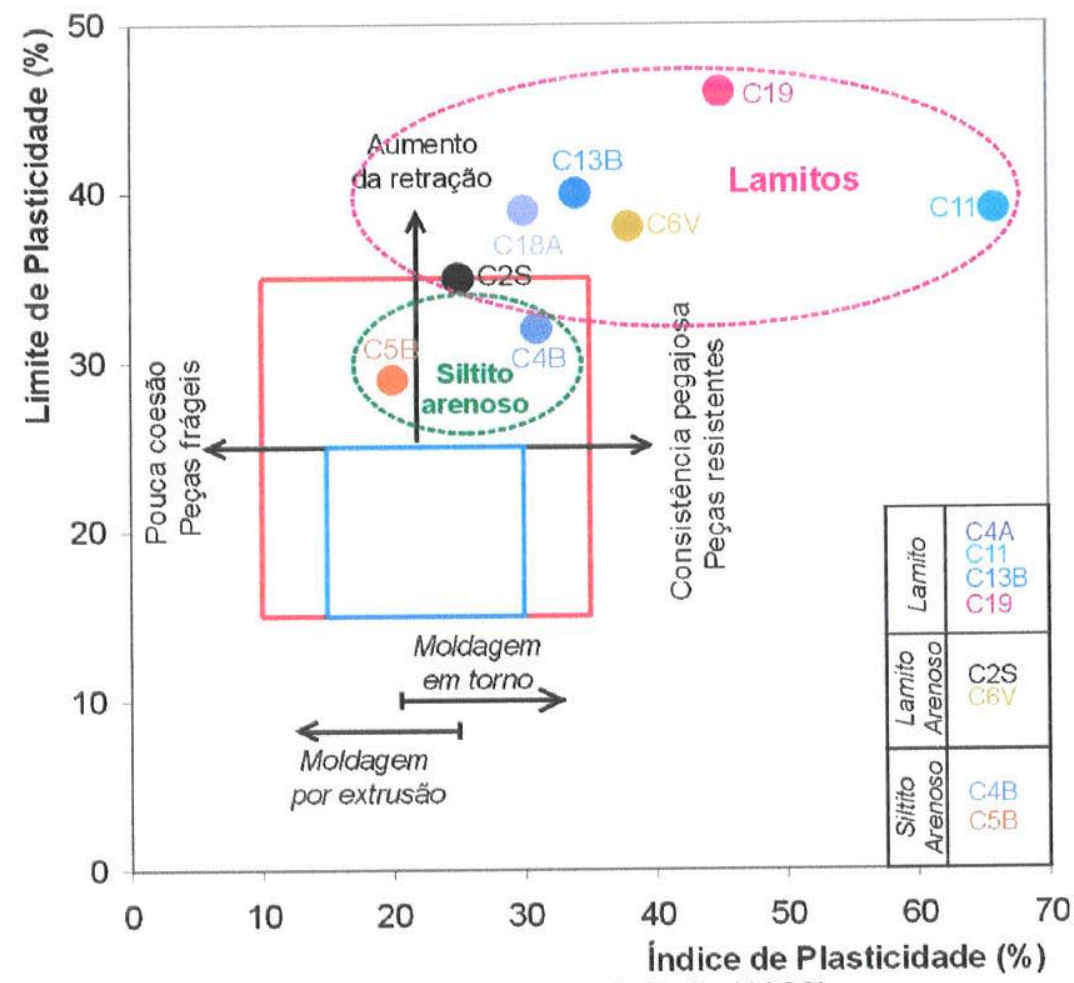

Figura 7.3: Diagrama de Bain (1986).

O retângulo vermelho define o intervalo de aceitação dos limites de plasticidade para cerâmica estrutural. Idealmente, os melhores índices encontram-se dentro do retângulo azul. Matérias-primas argilosas com índices à esquerda do diagrama são mais aceitáveis para conformação por extrusão, enquanto que para a direita, são mais apropriadas para moldagem manual ou em torno. 
Apenas as 3 amostras de siltitos arenosos mostraram-se apropriadas ao uso tal qual em cerâmica, considerando-se apenas o critério da plasticidade. As demais amostras mostraram-se excessivamente plásticas.

Os Limites de Atteberg obtidos mostraram que haveria a necessidade de adequação desses materiais aos limites aceitáveis. Essa correção poderia ser feita como Bain (1986) o fez, através da adição do mesmo volume de areia fina a uma argila montmorillonítica bastante plástica. No caso das amostras em estudo, o argilomineral beidellita pode apresentar propriedades reológicas diferentes da montmorillonita (bentonita), de forma que a correção poderia ser feita adicionando-se quartzo, na fração areia fina-silte, a fim de se atingir a plasticidade dos siltitos arenosos.

No caso da indústria de cerâmica de revestimento, as matérias-primas moídas são preparadas em barbotinas, que são suspensões aquosas com cerca de $60 \%$ de sólidos, nas quais o comportamento reológico é fundamental. Os limites de liquidez superiores a $50 \%$, promoveriam, no processamento a úmido, a necessidade de grande volume de água na preparação de barbotinas, consequentemente com maior gasto energético durante a atomização e secagem de peças conformadas.

Dessa forma, os resultados de plasticidade indicaram que os lamitos por si só não seriam adequados como matéria-prima cerâmica. No caso da cerâmica vermelha, o uso em proporções superiores a $50 \%$ seria vetado, devido à elevada plasticidade. Para a indústria cerâmica de revestimento, o material poderia ser empregado como aditivo, em dosagens a serem determinadas em estudos não contemplados nesse trabalho.

\subsubsection{Ensaios físicos nos corpos-de-prova pré queima}

Os parâmetros físicos determinados nos corpos de prova prensados e secos, umidade de prensagem $\left(H_{\text {prensa }}\right)$, retração linear de secagem (RS), módulo de ruptura à flexão (MRF) e cor, são apresentados na Tabela 7.3. Os resultados dos corpos-de-prova individuais estão no ANEXO 4.

As cores dos corpos-de-prova secos variaram entre levemente rosada, em amostras mais intemperizadas, e acastanhada a esverdeada, para amostras sãs. 
Tabela 7.3: Resultados de ensaios físicos nos corpos-de-prova a seco.

\begin{tabular}{|c|c|c|c|c|}
\hline Material & Amostra & Hprensa (\%) & RS (\%) & MRF (MPa) \\
\hline \multirow{4}{*}{ Lamito } & C4A & 5,154 & 0,678 & 3,6 \\
\cline { 2 - 5 } & C5A & 5,412 & 0,691 & 2,0 \\
\cline { 2 - 5 } & C11 & 5,519 & 0,711 & 3,0 \\
\cline { 2 - 5 } & C13B & 5,580 & 0,597 & 4,7 \\
\cline { 2 - 5 } & C19 & 5,993 & 0,721 & 3,5 \\
\hline \multirow{3}{*}{ Lamito arenoso } & C2S & 4,937 & 0,773 & 4,5 \\
\cline { 2 - 5 } & C6V & 4,897 & 0,420 & 2,6 \\
\hline \multirow{2}{*}{ Siltito arenoso } & C4B & 4,101 & 0,591 & 2,9 \\
\cline { 2 - 5 } & C5B & 4,344 & 0,722 & 2,4 \\
\hline
\end{tabular}

Umidade de prensagem ( $\left.H_{\text {prensa }}\right)$; retração linear de secagem $(R S)$ e Módulo de ruptura à flexão (MRF) para corpos-de-prova secos à $110^{\circ} \mathrm{C}$.

* determinado no eixo maior dos corpos-de-prova

A umidade de prensagem utilizada foi inferior a $6 \%$, sendo os maiores valores relacionados aos lamitos, refletindo a elevada higroscopia dos argilominerais esmectíticos. A retração linear de secagem foi inferior a $0,70 \%$, resultado relativamente elevado comparativamente ao $0,36 \%$ obtido para amostras de argilito e ritmito do Subgrupo Itararé, estudadas por Florêncio (1999).

As resistências mecânicas obtidas estão em conformidade com os valores-limite, estabelecidos por Souza Santos (1989), para corpos-de-prova secos. De maneira geral, as resistências mecânicas dos lamitos e lamitos arenosos foram superiores às de siltitos arenosos, fato possivelmente relacionado ao melhor empacotamento de partículas obtido na prensagem.

\subsubsection{Ensaios físicos em corpos-de-prova pós queima}

Os parâmetros determinados após a queima de corpos-de-prova, perda ao fogo (PF); retração linear de queima (RQ); módulo de ruptura à flexão (MRF); absorção de água (AA); massa específica aparente (MEA); massa especifica aparente da parte sólida $\left(M A_{s o l l d a}\right) ;$ porosidade aparente (PA) e cor de queima, são apresentados nas Tabelas 7.4 e 7.5. Os resultados dos corpos-de-prova individuais estão no ANEXO 4. 
Tabela 7.4: Resultados dos ensaios físicos nos corpos-de-prova queimados à $950^{\circ} \mathrm{C}$.

\begin{tabular}{|c|c|c|c|c|c|c|c|c|}
\hline \multirow[b]{2}{*}{ Material } & \multicolumn{8}{|c|}{ Queima a $950^{\circ} \mathrm{C}$} \\
\hline & Amostra & $\mathrm{PF}(\%)$ & RQ $(\%)$ & $\begin{array}{l}\text { MRF } \\
\text { (MPa) }\end{array}$ & $\mathrm{AA}(\%)$ & $\begin{array}{c}\mathrm{MEA} \\
\left(\mathrm{g} / \mathrm{cm}^{3}\right)\end{array}$ & $\begin{array}{l}\text { MEA sifd } \\
\left(\mathrm{g} / \mathrm{cm}^{2}\right)\end{array}$ & $\mathrm{PA}(\%)$ \\
\hline \multirow{5}{*}{ Lamito } & $\mathrm{C} 4 \mathrm{~A}$ & 8,04 & 2,31 & 10,00 & 17,17 & 1,84 & 2,69 & 31,62 \\
\hline & C5A & 9,67 & 3,11 & 9,50 & nd. & nd. & nd. & nd. \\
\hline & C11 & 9,33 & 3,92 & 14,10 & 18,06 & 1,82 & 2,72 & 32,92 \\
\hline & C13B & 9,72 & 3,73 & 9,70 & 17,32 & 1,87 & 2,76 & 32,33 \\
\hline & C19 & 9,19 & 3,53 & 16,20 & 16,38 & 1,89 & 2,73 & 30,92 \\
\hline & & & & & & & & \\
\hline \multirow{2}{*}{$\begin{array}{l}\text { Lamito } \\
\text { arenoso }\end{array}$} & $\mathrm{C} 2 \mathrm{~S}$ & 7,67 & 1,73 & 8,30 & 16,88 & 1,86 & 2,70 & 31,29 \\
\hline & $\mathrm{C} 6 \mathrm{~V}$ & 9,61 & 3,50 & 12,10 & 16,08 & 1,91 & 2,76 & 30,76 \\
\hline & & & & & & & & \\
\hline \multirow{2}{*}{$\begin{array}{l}\text { Siltito } \\
\text { arenoso }\end{array}$} & C4B & 7,53 & 1,69 & 8,70 & 16,44 & 1,87 & 2,71 & 30,77 \\
\hline & C5B & 5,87 & 0,61 & 4,10 & 15,52 & 1,88 & 2,65 & 29,11 \\
\hline
\end{tabular}

nd. não determinado

Os resultados foram avaliados individualmente, evitando-se assumir valores médios que pudessem mascarar alguma diferença significativa ou induzir a uma interpretação tendenciosa com base na litologia do material.

Os resultados dos ensaios físicos realizados em corpos-de-prova de lamitos queimados à $950^{\circ} \mathrm{C}$, apresentaram variações pouco significativas quando comparados aos siltitos arenosos.

Embora a amostra C6V seja de lamito arenoso, o comportamento após queima foi similar aos lamitos. Essa amostra é composta de 15\% de areia quartzosa e $85 \%$ de silte mais argila (caulinita e illita), e possui composição química semelhante aos lamitos, porém diferencia-se deles pela a ausência de esmectita, o que deve ter contribuído positivamente na definição dos parâmetros físicos.

As melhores resistências mecânicas foram encontradas em amostras de lamitos, seguidas pelas de lamitos arenosos e de siltitos arenosos, exceto pela amostra C6V. Esse comportamento seletivo deveu-se a características intrínsecas ao material natural. Os materiais lamiticos por serem granulometricamente finos, possibilitaram a melhor compactação na prensagem e melhor sinterização dos corpos-de-prova durante a queima, devido à maior relação óxidos fundentes $/$ óxidos $_{\text {refratários }}$ comparativamente aos siltitos arenosos.

Os parâmetros massa específica aparente do corpo-de-prova e massa específica aparente da parte sólida pouco variaram. Os resultados de perda ao fogo foram diretamente proporcionais à quantidade e ao tipo de argilominerais, que perderam massa durante a queima, enquanto que o quartzo sofreu apenas mudanças estruturais. 
Tabela 7.5: Resultados dos ensaios físicos nos corpos-de-prova queimados à $1100^{\circ} \mathrm{C}$.

\begin{tabular}{|c|c|c|c|c|c|c|c|c|}
\hline \multirow[b]{2}{*}{ Material } & \multicolumn{3}{|c|}{ 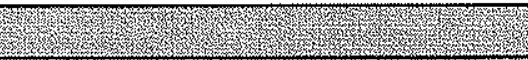 } & \multicolumn{2}{|c|}{ Queima a $1100^{\circ} \mathrm{C}$} & 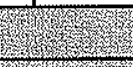 & 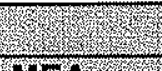 & \multirow[b]{2}{*}{$\mathrm{PA}(\%)$} \\
\hline & Amostra & $\mathrm{PF}(\%)$ & $R Q(\%)$ & $\begin{array}{l}\text { MRF } \\
(\mathrm{MPa})\end{array}$ & $\mathrm{AA}(\%)$ & $\begin{array}{c}\mathrm{MEA} \\
\left(\mathrm{g} / \mathrm{cm}^{3}\right)\end{array}$ & $\begin{array}{l}\text { MEAssilda } \\
\left(\mathrm{g} / \mathrm{cm}^{2}\right)\end{array}$ & \\
\hline \multirow{5}{*}{ Lamito } & C4A & 8,47 & 9,66 & 20,48 & 6,03 & 2,30 & 2,67 & 13,86 \\
\hline & C5A & 8,98 & 12,46 & 27,00 & nd. & nd. & nd. & nd. \\
\hline & $\mathrm{C} 11$ & 10,19 & 14,86 & 46,21 & 0,64 & 2,62 & 2,66 & 1,68 \\
\hline & C13B & 10,13 & 12,40 & 22,11 & 2,42 & 2,53 & 2,70 & 6,12 \\
\hline & $\mathrm{C} 19$ & 9,93 & 12,55 & 29,83 & 2,12 & 2,54 & 2,68 & 5,37 \\
\hline \multirow{2}{*}{$\begin{array}{c}\text { Lamito } \\
\text { arenoso }\end{array}$} & $\mathrm{C} 2 \mathrm{~S}$ & 8.14 & 6.40 & 12,76 & 8.22 & 2,19 & 2,67 & 18,01 \\
\hline & $\mathrm{C} 6 \mathrm{~V}$ & 10,22 & 11,91 & 39,77 & 2,12 & 2,59 & 2,74 & 5,45 \\
\hline & & & & & & & & \\
\hline \multirow{2}{*}{$\begin{array}{c}\text { Siltito } \\
\text { arenoso }\end{array}$} & $\mathrm{C} 4 \mathrm{~B}$ & 8,15 & 7,50 & 16,08 & 8,06 & 2,21 & $\frac{2,69}{2,61}$ & $\frac{17,79}{2416}$ \\
\hline & $\mathrm{C} 5 \mathrm{~B}$ & 5,95 & 2,96 & 6,03 & 12,20 & 1,98 & 2,61 & 24,16 \\
\hline
\end{tabular}

Módulos de ruptura à flexão após queima (MRF); absorção de água (AA); massa especifica aparente (MEA); massa especifica aparente $\left(M^{2} A_{\text {soblida }}\right)$ e porosidade aparente (PA).

nd. não determinado

A queima à $1.100^{\circ} \mathrm{C}$ promoveu importantes transformações nos constituintes mineralógicos das amostras, fato que se refletiu nas propriedades físicas dos corpos de prova. Comparando-se com os resultados de queima à $950^{\circ} \mathrm{C}$, as resistências mecânicas foram acrescidas em pelo menos $100 \%$, enquanto que a absorção de água foi sensivelmente reduzida de valores entre $15-18 \%$, para valores inferiores a $8,22 \%$, com exceção da amostra C5B que manteve absorção superior a $12 \%$ por ser a amostra mais arenosa.

Novamente a amostra C6V apresentou valores muito similares aos lamitos para todas as propriedades físicas determinadas.

Os produtos de queima apresentaram sempre coloração avermelhada, devido aos teores de $\mathrm{Fe}_{2} \mathrm{O}_{3}$ (Figura 7.4). Embora os resultados físicos obtidos tenham sido satisfatórios, foram observadas leves deformações em alguns corpos-de-prova (empenamento e pequenas trincas), possivelmente relacionadas à composição esmectítica do material (Figura 7.5). 

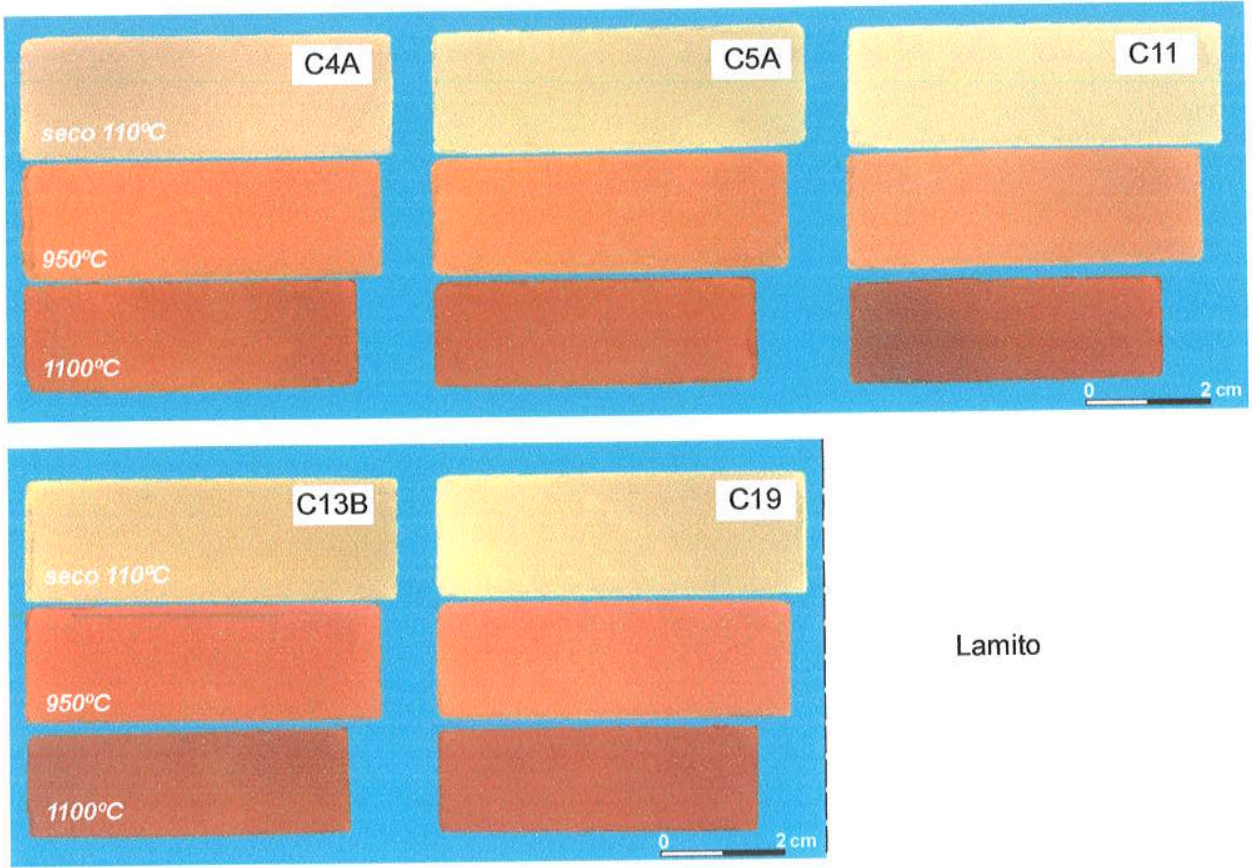

Lamito
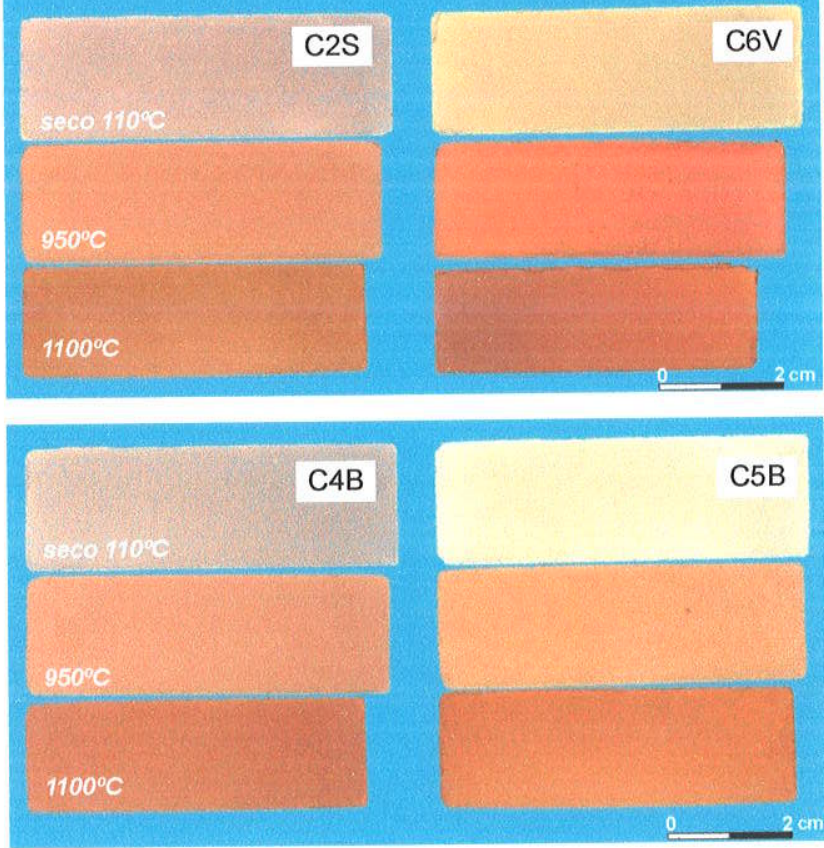

Lamito arenoso

Siltito arenoso

Figura 7.4: Corpos-de-prova secos e queimados à $950^{\circ} \mathrm{C}$ e $1100^{\circ} \mathrm{C}$.

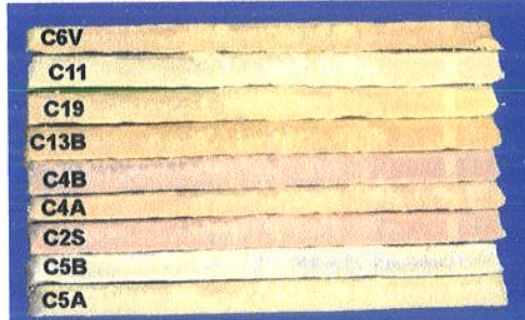

$\sec$ a $110^{\circ} \mathrm{C}$

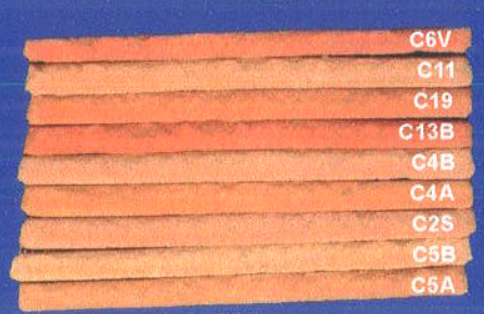

$950^{\circ} \mathrm{C}$

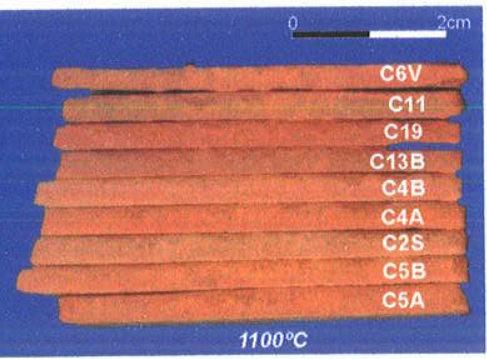

$1100^{\circ} \mathrm{C}$

Figura 7.5: Perfil dos corpos-de-prova secos e queimados à $950^{\circ} \mathrm{C}$ e $1100^{\circ} \mathrm{C}$. 


\subsubsection{Considerações gerais sobre os ensaios cerâmicos}

A avaliação conjunta dos resultados dos ensaios cerâmicos foi realizada através de uma matriz de correlação, considerando-se as propriedades cerâmicas e as características das amostras obtidas na caracterização. Resultaram dessa análise os coeficientes de correlação (Tabelas 7.6 e 7.7), obtidos com a ferramenta de Análise de Dados do Microsoft $\circledast$ Excel 97.

Os coeficientes de correlação foram classificados arbitrariamente em três intervalos: $\geq|0,70| ;|0,50|<$ correlação $<|0,70| e \leq|0,50|$. No primeiro intervalo estariam as correlações significativas, no segundo, correlações intermediárias, e no último, as correlações ruins.

Foram notadas algumas dependências entre as propriedades cerâmicas obtidas pela queima à $950^{\circ} \mathrm{C}$ e as características naturais das amostras. Os parâmetros físicos $\mathrm{PF}$, MRF, RQ e PA foram correlacionáveis aos parâmetros de granulometria, composição mineralógica e, também, à composição química da rocha.

A absorção de água e a massa específica aparente mostraram-se pouco correlacionáveis com as demais propriedades, devido às parciais transformações de fases ocorridas à temperatura de $950^{\circ} \mathrm{C}$. Como a temperatura não foi suficiente para promover a nucleação de novas fases cristalinas, o produto da queima manteve parte das propriedades originais. Provavelmente a absorção de água não resultou apenas do preenchimento de vazios (porosidade aparente), mas também decorreu da capacidade residual de adsorção de água do material original. Como o comportamento da massa especifica aparente é similar ao da absorção de água, a correlação também foi pequena com os demais parâmetros. 
Tabela 7.6: Matriz de correlação entre propriedades cerâmicas e características naturais das matérias-primas para produtos de queima à $950^{\circ} \mathrm{C}$.

\begin{tabular}{|c|c|c|c|c|c|c|c|c|c|c|c|c|c|c|c|}
\hline \multirow{2}{*}{$\begin{array}{c}\text { Coeficiente de } \\
\text { Correlação (R) } \\
950^{\circ} \mathrm{C}\end{array}$} & \multicolumn{7}{|c|}{ Propriedades fisicas dos corpos-de-prova queimados } & \multicolumn{4}{|c|}{$\begin{array}{l}\text { Propriedades texturais das amostras } \\
\text { naturais }\end{array}$} & \multicolumn{4}{|c|}{$\begin{array}{l}\text { Propriedades químicas das } \\
\text { amostras naturais }\end{array}$} \\
\hline & 㟔 す & d̊ & $\begin{array}{l}\frac{u}{\tilde{\sigma}} \\
\stackrel{\tilde{\alpha}}{\Sigma} \\
\stackrel{0}{\Sigma}\end{array}$ & \& & 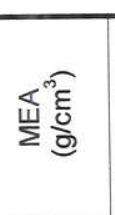 & 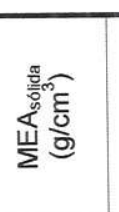 & $\llbracket \lesssim$ & 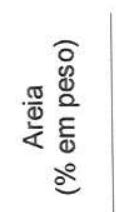 & 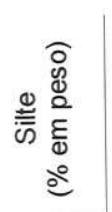 & 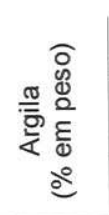 & 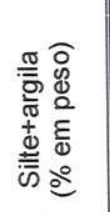 & 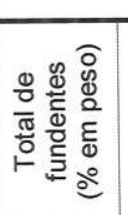 & 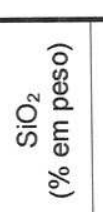 & 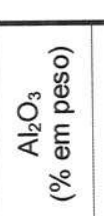 & 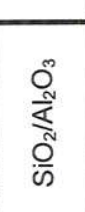 \\
\hline $\mathrm{PF}(\%)$ & 1,00 & & & & & & & & & & & & & & \\
\hline$R Q(\%)$ & 0,98 & 1,00 & & & & & & & & & & & & & \\
\hline MRF (MPa) & 0,80 & 0,85 & 1,00 & & & & & & & & & & & & \\
\hline $\mathrm{AA}(\%)$ & 0,54 & 0,58 & 0,43 & 1,00 & & & & & & & & & & & \\
\hline $\operatorname{MEA}\left(\mathrm{g} / \mathrm{cm}^{3}\right)$ & 0,08 & $-0,01$ & 0,02 & $-0,79$ & 1,00 & & & & & & & & & & \\
\hline $\operatorname{MEA}_{\text {solida }}\left(\mathrm{g} / \mathrm{cm}^{3}\right)$ & 0,94 & 0,87 & 0,67 & 0,32 & 0,33 & 1,00 & & & & & & & & & \\
\hline $\mathrm{PA}(\%)$ & 0,72 & 0,74 & 0,55 & 0,97 & $-0,60$ & 0,55 & 1,00 & & & & & & & & \\
\hline Areia (\% em peso) & $-0,72$ & $-0,79$ & $-0,70$ & $-0,67$ & 0,31 & $-0,55$ & $-0,74$ & 1,00 & & & & & & & \\
\hline Silte (\% em peso) & $-0,50$ & $-0,55$ & $-0,49$ & $-0,46$ & 0,23 & $-0,34$ & $-0,49$ & 0,15 & 1,00 & & & & & & \\
\hline Argila (\% em peso) & 0,79 & 0,87 & 0,77 & 0,73 & $-0,35$ & 0,58 & 0,80 & $-0,72$ & $-0,79$ & 1,00 & & & & & \\
\hline Silte+argila (\% em peso) & 0,72 & 0,79 & 0,70 & 0,67 & $-0,31$ & 0,55 & 0,74 & $-1,00$ & $-0,15$ & 0,72 & 1,00 & & & & \\
\hline Total de fundentes (\% em peso) & 0,82 & 0,81 & 0,61 & 0,49 & 0,03 & 0,80 & 0,65 & $-0,88$ & $-0,04$ & 0,57 & 0,88 & 1,00 & & & \\
\hline $\mathrm{SiO}_{2}(\%$ em peso $)$ & $-0,99$ & $-0,97$ & $-0,81$ & $-0,59$ & $-0,01$ & $-0,92$ & $-0,76$ & 0,80 & 0,40 & $-0,78$ & $-0,80$ & $-0,88$ & 1,00 & & \\
\hline $\mathrm{Al}_{2} \mathrm{O}_{3}$ (\% em peso) & 0,97 & 0,95 & 0,82 & 0,60 & 0,01 & 0,91 & 0,77 & $-0,72$ & $-0,42$ & 0,74 & 0,72 & 0,80 & $-0,98$ & 1,00 & \\
\hline $\mathrm{SiO}_{2} / \mathrm{Al}_{2} \mathrm{O}_{3}$ & $-0,96$ & $-0,93$ & $-0,82$ & $-0,62$ & 0,02 & $-0,91$ & $-0,79$ & 0,74 & 0,38 & $-0,72$ & $-0,74$ & $-0,83$ & 0,98 & $-0,99$ & 1,00 \\
\hline
\end{tabular}

Perda ao Fogo (PF); Retração linear de queima (RQ); Módulo de ruptura à flexão (MRF); Absorção de água (AA); Massa específica aparente (MEA); Massa específica aparente (MEA sólida) e Porosidade aparente (PA).

Coeficiente de correlação $\leq|0,50|$ - correlação ruim (célula branca)

$|0,50|<$ Coeficiente $<|0,70|$ - correlação intermediária (célula azul)

Coeficiente de correlação $\geq|0,70|$ - correlação significativa (célula cinza)

Valores positivos - correlação positiva

Valores negativos - correlação negativa 
Os produtos cerâmicos obtidos a partir da queima à $1100^{\circ} \mathrm{C}$ mostraram maior quantidade de correlações significativas com as características naturais das amostras, comparativamente aos resultados obtidos para os produtos de queima à $950^{\circ} \mathrm{C}$ (Figura 7.6).

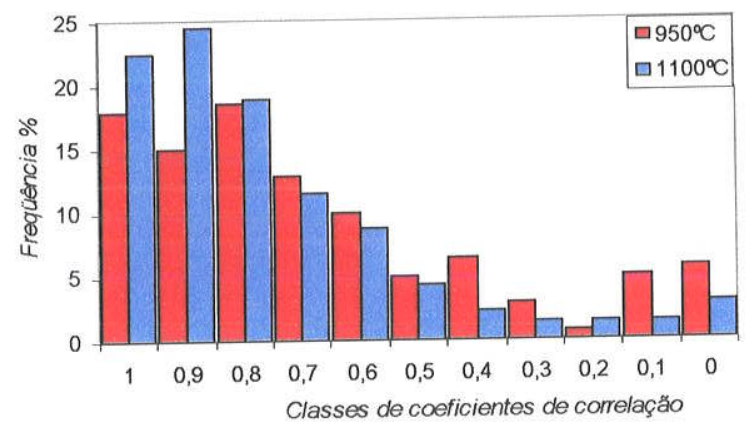

Figura 7.6: Histograma de distribuição de freqüências para os coeficientes de correlação para as temperaturas de queima de $950^{\circ} \mathrm{C}$ e $1100^{\circ} \mathrm{C}$.

Uma das mais importantes correlações observadas foi entre as propriedades cerâmicas MRF, $A A$ e RQ, e as características granulométricas e químicas. A Figura 7.7 mostra a variação das propriedades físicas dos corpos cerâmicos queimados à $1100^{\circ} \mathrm{C}$ em função da granulometria dos materiais estudados. Os lamitos apresentaram as maiores resistências mecânicas e retrações de queima, somadas aos menores índices de absorção de água. Por outro lado, os materiais mais arenosos mostraram resultados menos satisfatórios.

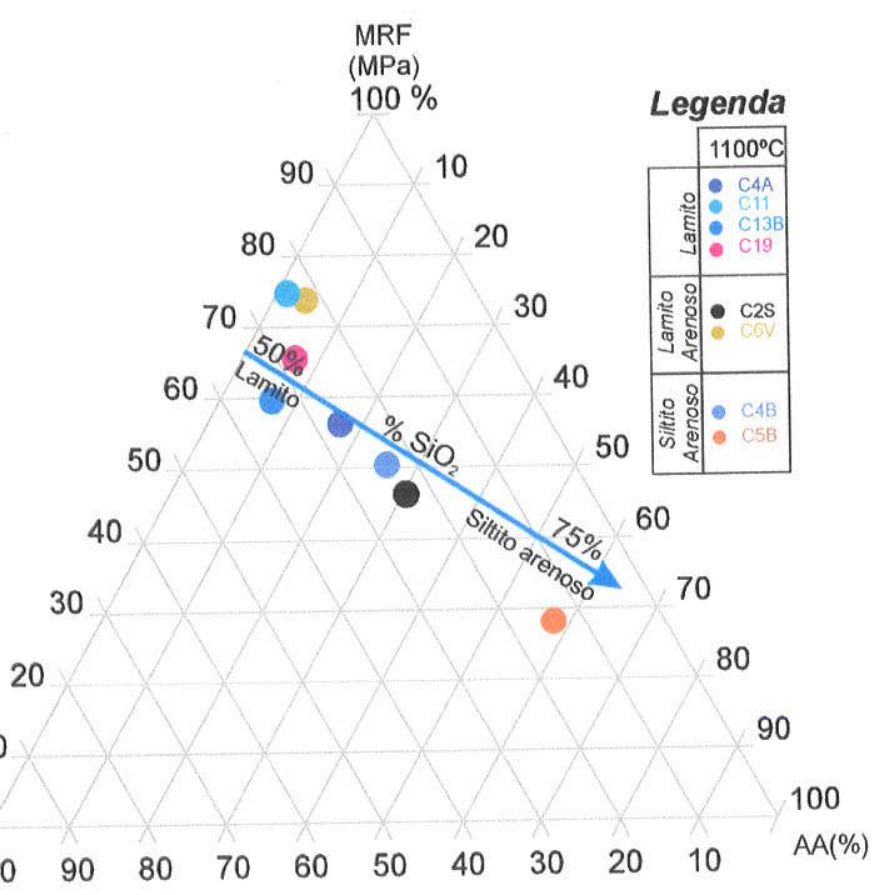

Figura 7.7: Diagrama ternário com MRFXAAxRQ para temperatura de $1100^{\circ} \mathrm{C}$, mostrando a influência da tipologia do material nas propriedades cerâmicas (resultados recalculados para 100\%). 
Tabela 7.7: Matriz de correlação entre propriedades cerâmicas e características naturais das matérias-primas para produtos de queima à $1100^{\circ} \mathrm{C}$

\begin{tabular}{|c|c|c|c|c|c|c|c|c|c|c|c|c|c|c|c|}
\hline \multirow{2}{*}{$\begin{array}{c}\text { Coeficiente de } \\
\text { Correlação (R) } \\
\qquad 1100^{\circ} \mathrm{C}\end{array}$} & \multicolumn{7}{|c|}{ Propriedades físicas dos corpos-de-prova queimados } & \multicolumn{4}{|c|}{$\begin{array}{l}\text { Propriedades texturais das amostras } \\
\text { naturais }\end{array}$} & \multicolumn{4}{|c|}{$\begin{array}{l}\text { Propriedades químicas das } \\
\text { amostras naturais }\end{array}$} \\
\hline & 4 号 & ๔o & 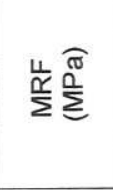 & 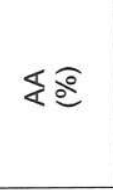 & 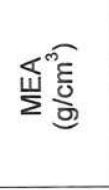 & 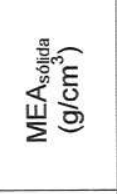 & $₫ \lesssim$ & 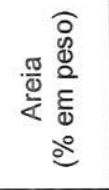 & 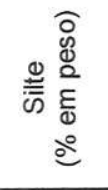 & 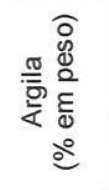 & 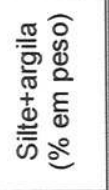 & 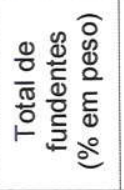 & 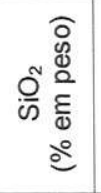 & 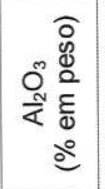 & 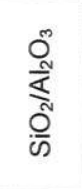 \\
\hline $\mathrm{PF}(\%)$ & 1,00 & & & & & & & & & & & & & & \\
\hline$R Q(\%)$ & 0,96 & 1,00 & & & & & & & & & & & & & \\
\hline $\operatorname{MRF}(\mathrm{MPa})$ & 0,84 & 0,90 & 1,00 & & & & & & & & & & & & \\
\hline $\mathrm{AA}(\%)$ & $-0,98$ & $-0,99$ & $-0,90$ & 1,00 & & & & & & & & & & & \\
\hline MEA $\left(\mathrm{g} / \mathrm{cm}^{3}\right)$ & 0,98 & 0,98 & 0,91 & $-1,00$ & 1,00 & & & & & & & & & & \\
\hline$M E A_{\text {solita }}\left(\mathrm{g} / \mathrm{cm}^{3}\right)$ & 0,74 & 0,56 & 0,52 & $-0,62$ & 0,66 & 1,00 & & & & & & & & & \\
\hline $\mathrm{PA}(\%)$ & $-0,96$ & $-0,99$ & $-0,91$ & 1,00 & $-0,99$ & $-0,58$ & 1,00 & & & & & & & & \\
\hline Areia (\% em peso) & $-0,73$ & $-0,84$ & $-0,59$ & 0,78 & $-0,74$ & $-0,25$ & 0,78 & 1,00 & & & & & & & \\
\hline Silte (\% em peso) & $-0,50$ & $-0,49$ & $-0,54$ & 0,54 & $-0,53$ & $-0,10$ & 0,56 & 0,15 & 1,00 & & & & & & \\
\hline Argila (\% em peso) & 0,80 & 0,86 & 0,74 & $-0,86$ & 0,83 & 0,22 & $-0,87$ & $-0,72$ & $-0,79$ & 1,00 & & & & & \\
\hline Silte+argila (\% em peso) & 0,73 & 0,84 & 0,59 & $-0,78$ & 0,74 & 0,25 & $-0,78$ & $-1,00$ & $-0,15$ & 0,72 & 1,00 & & & & \\
\hline Total de fundentes (\% em peso) & 0,81 & 0,80 & 0,50 & $-0,78$ & 0,77 & 0,58 & $-0,76$ & $-0,88$ & $-0,04$ & 0,57 & 0,88 & 1,00 & & & \\
\hline $\mathrm{SiO}_{2}(\%$ em peso) & $-0,99$ & $-0,96$ & $-0,81$ & 0,97 & $-0,97$ & $-0,72$ & 0,95 & 0,80 & 0,40 & $-0,78$ & $-0,80$ & $-0,88$ & 1,00 & & \\
\hline $\mathrm{Al}_{2} \mathrm{O}_{3}(\%$ em peso) & 0,99 & 0,95 & 0,85 & $-0,96$ & 0,96 & 0,77 & $-0,94$ & $-0,72$ & $-0,42$ & 0,74 & 0,72 & 0,80 & $-0,98$ & 1,00 & \\
\hline $\mathrm{SiO}_{2} / \mathrm{Al}_{2} \mathrm{O}_{3}$ & $-0,98$ & $-0,93$ & $-0,79$ & 0,94 & $-0,93$ & $-0,78$ & 0,91 & 0,74 & 0,38 & $-0,72$ & $-0,74$ & $-0,83$ & 0,98 & $-0,99$ & 1,00 \\
\hline
\end{tabular}

Perda ao Fogo (PF); Retração linear de queima (RQ); Módulo de ruptura à flexão (MRF); Absorção de água (AA); Massa específica aparente (MEA); Massa específica aparente (MEA $A_{\text {solida }}$ ) e Porosidade aparente (PA).

Coeficiente de correlação $\leq|0,50|$ - correlação ruim (célula branca)

$|0,50|<$ Coeficiente $<|0,70|$ - correlação intermediária (célula azul)

Coeficiente de correlação $\geq|0,70|$ - correlação significativa (célula cinza)

Valores positivos - correlação positiva

Valores negativos - correlação negativa 
A melhoria nas propriedades físicas cerâmicas pôde ser atribuída às transformações térmicas decorrentes da queima à $1100^{\circ} \mathrm{C}$ (sinterização), que foram confirmadas pela interpretação de difratogramas de corpos-de-prova queimados.

As ferramentas de microscopia eletrônica de varredura (MEV) e difração de raios $X$ (DRX) revelaram importantes transformações de fases ocorridas no processo cerâmico (Prancha 7.1). Para os produtos de queima à $950^{\circ} \mathrm{C}$, embora a textura original tenha sido pouco modificada, verificou-se nos difratogramas o desaparecimento das reflexões basais da caulinita à 7 e 3,5 $\AA$, enquanto que a esmectita sofreu a desidroxilação, e a posição de sua reflexão basal (001) passou a coincidir com o pico da illita à $10 \AA$, ainda preservada. Os picos agudos de alta intensidade corresponderam ao quartzo ou seu polimorfo de alta temperatura (cristobalita); fases amorfas foram reconhecidas por um abaulamento muito sutil do perfil difratométrico entre 18 e $422 \theta$.

As transformações de fases à $1100^{\circ} \mathrm{C}$ foram mais intensas que à $950^{\circ} \mathrm{C}$. Em MEV, observouse que $o$ aspecto originalmente composto por aglomerados de finas placas de argilominerais passou a compor uma textura aparentemente vítrea, na qual puderam ser reconhecidos alguns grãos isolados de quartzo. Por DRX, observou-se que os reticulos cristalinos minerais originais foram destruídos, tendo resultado em estruturas neoformadas como a mulita, cristobalita e espinélio (Prancha 7.1). 

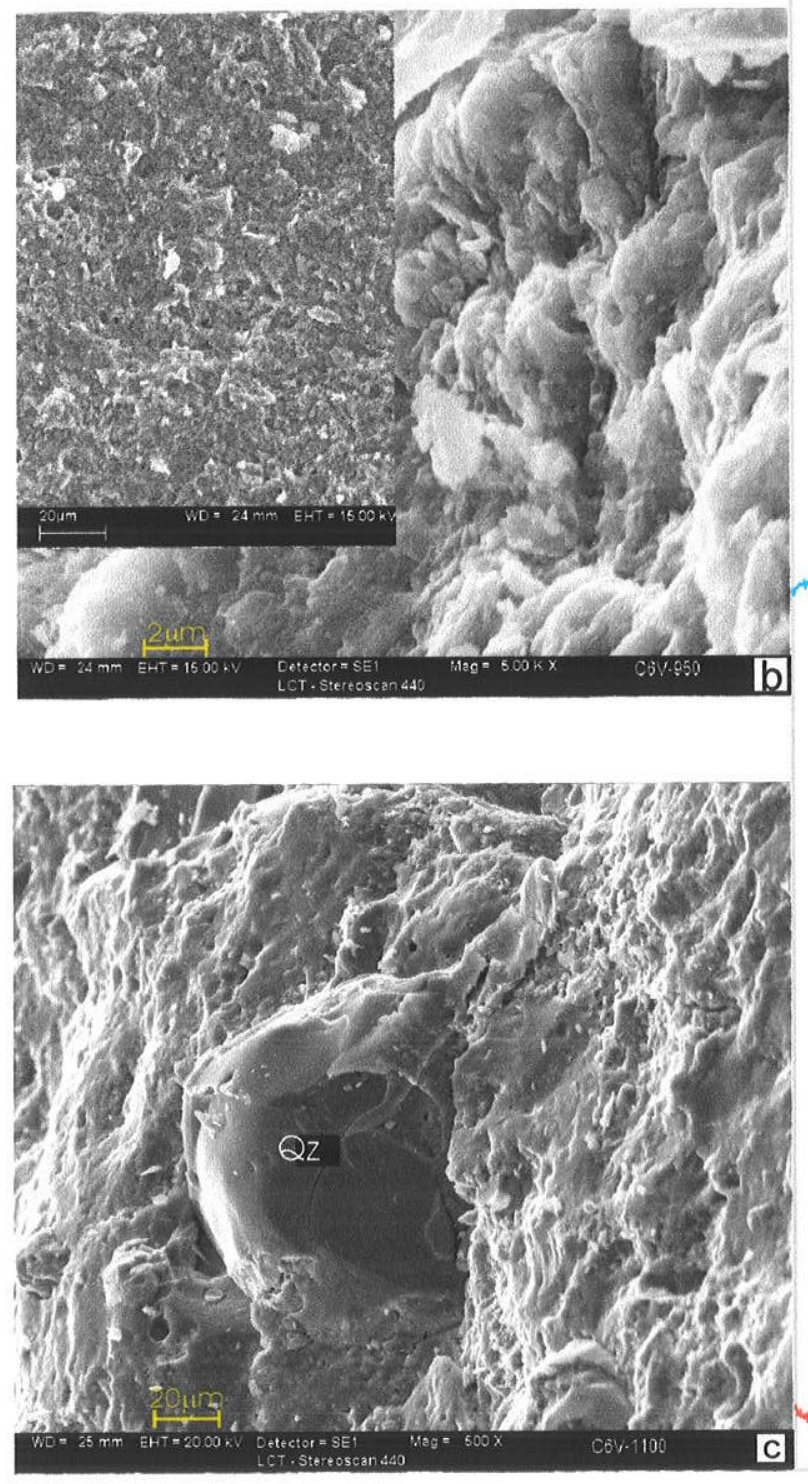

a

b
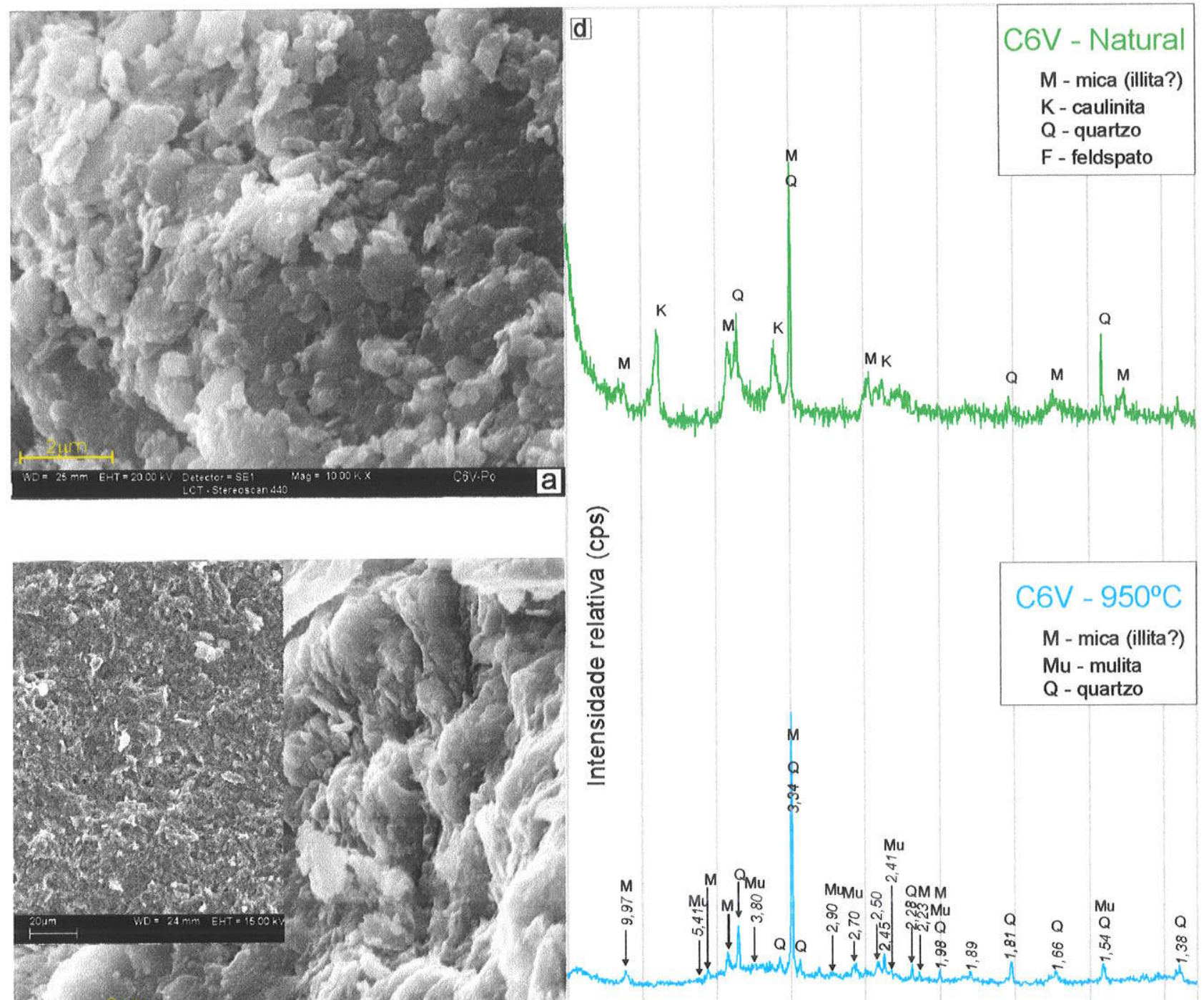

$$
\begin{aligned}
& \begin{array}{llllllll}
10,5 & 18,5 & 26,5 & 34,5 & 42,5 & 50,5 & 58,5 & 66,5
\end{array} \\
& 2 \theta-\mathrm{CuK} \alpha
\end{aligned}
$$

$\mathrm{C} 6 \mathrm{~V}-950^{\circ} \mathrm{C}$

$\mathrm{Cr}$ - cristobalita $S$ - espinélio He - hematita M - mica (illita?) Mu - mulita Q - quartzo

Prancha 7.1: Imagens obtidas ao microscópio eletrônico de varredura, utilizando elétrons secundários e difratogramas: (a) material natural; (b) queimado à $950^{\circ} \mathrm{C}$; (c) queimado à $1100^{\circ} \mathrm{C}$; (d) difratogramas de raios $\mathrm{X}$ (amostra C6V). 
Procurou-se verificar a aplicabilidade dos produtos de queima obtidos segundo as especificações dos segmentos de cerâmica estrutural e de revestimento. Os resultados de absorção de água e módulo de ruptura à flexão, em produtos de queima à $950^{\circ} \mathrm{C}$, foram comparados aos valores-limite atribuídos por Souza Santos (1989) para a qualificação de matérias-primas, em corpos-de-prova prensados em laboratório (Figura 7.8a).
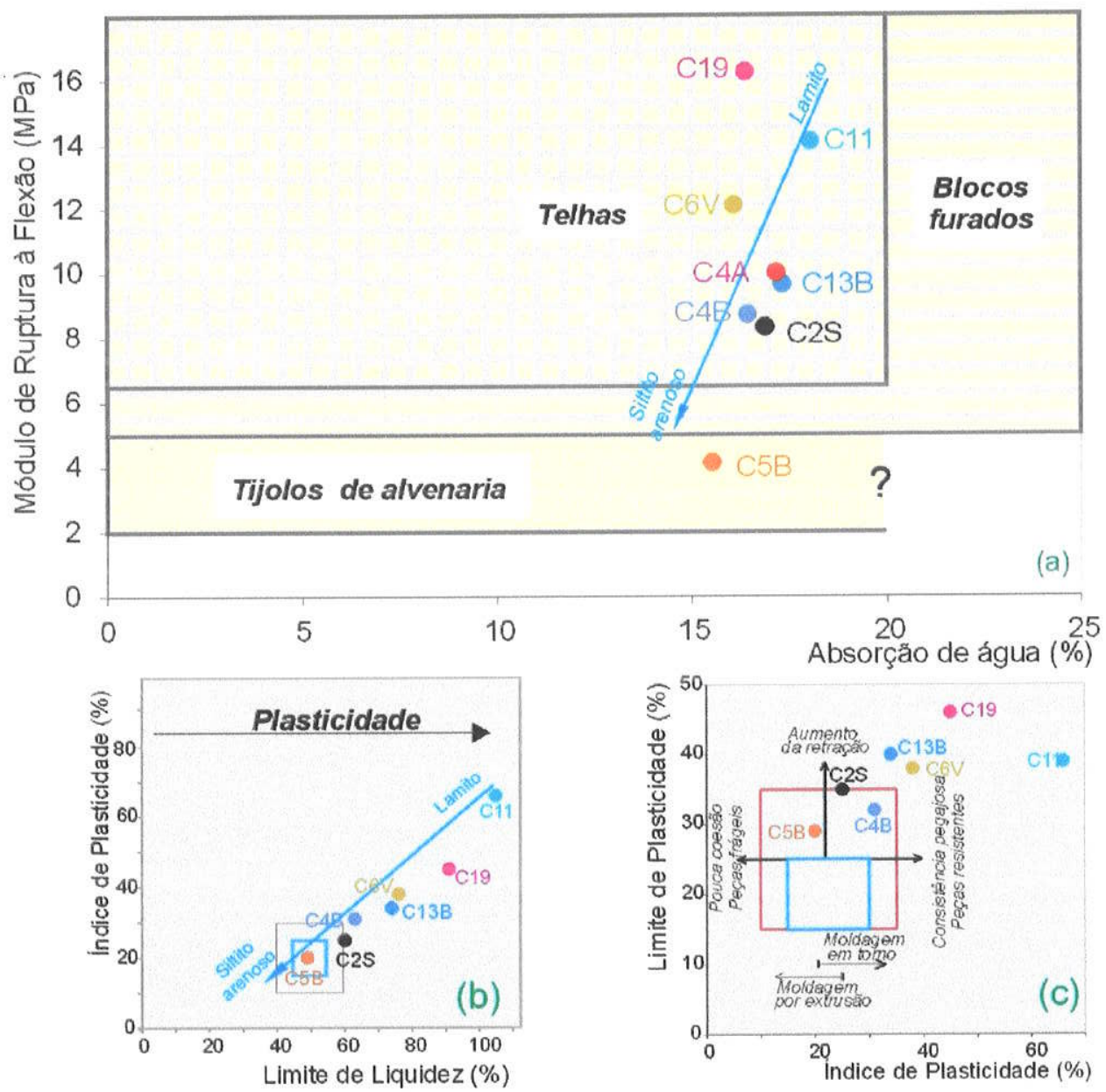

Figura 7.8: (a) Classificação dos produtos de queima, segundo Souza Santos (1989), baseada em absorção de água e módulo de ruptura à flexão, para corpos-de-prova conformados por prensagem. (A seta representa a linha de tendência obtida para o conjunto de dados); (b) Diagrama simplificado de Casagrande, segundo Gippini (1969), com os dados de limite de liquidez e índice de plasticidade; (c) Diagrama de Bain (1986).

Segundo a classificação de Souza Santos (1989), considerando-se apenas os parâmetros absorção de água e módulo de ruptura à flexão, os lamitos, lamitos arenosos e siltitos são plenamente adequados à confecção de tijolos de alvenaria. Para a fabricação de blocos furados e telhas os materiais estudados mostraram-se também adequados, exceto a amostra C5B, que por ser muito arenosa não apresentou bom desempenho mecânico. 
$\mathrm{Na}$ avaliação dos limites de plasticidade a amostra C5B mostrou os melhores resultados e, segundo a classificação de Gippini (1986) -Figura 7.8b, foi a que após a queima apresentou os piores resultados: os resultados obtidos para os corpos-de-prova queimados à $950^{\circ} \mathrm{C}$ não confirmaram as expectativas. Possivelmente, essa discrepância esteja associada à forma de conformação empregada.

A análise dos limites de Atteberg em conjunto com os resultados cerâmicos (absorção de água $x$ módulo de ruptura à flexão) permitiu verificar que os materiais mais plásticos apresentaram as maiores resistências mecânicas e os menores valores de absorção de água, como sugerido pelo diagrama de Bain (1986) - Figura 7.8c, para limites de plasticidade.

A partir dos ensaios realizados, buscou-se também verificar o enquadramento das amostras de acordo com as classes de resistência mecânica e absorção de água estabelecidas pela NBR13817 (ABNT, 1997) para placas cerâmicas de revestimento. Essa classificação foi realizada graficamente através do diagrama absorção de água x módulo de ruptura à flexão, na qual foram definidos campos separados por valores-limite de parâmetros, e por processos de conformação (extrusão e prensagem). A classificação em produtos acabados (porcelanato, grés, etc.) baseou-se em ABC (1998).

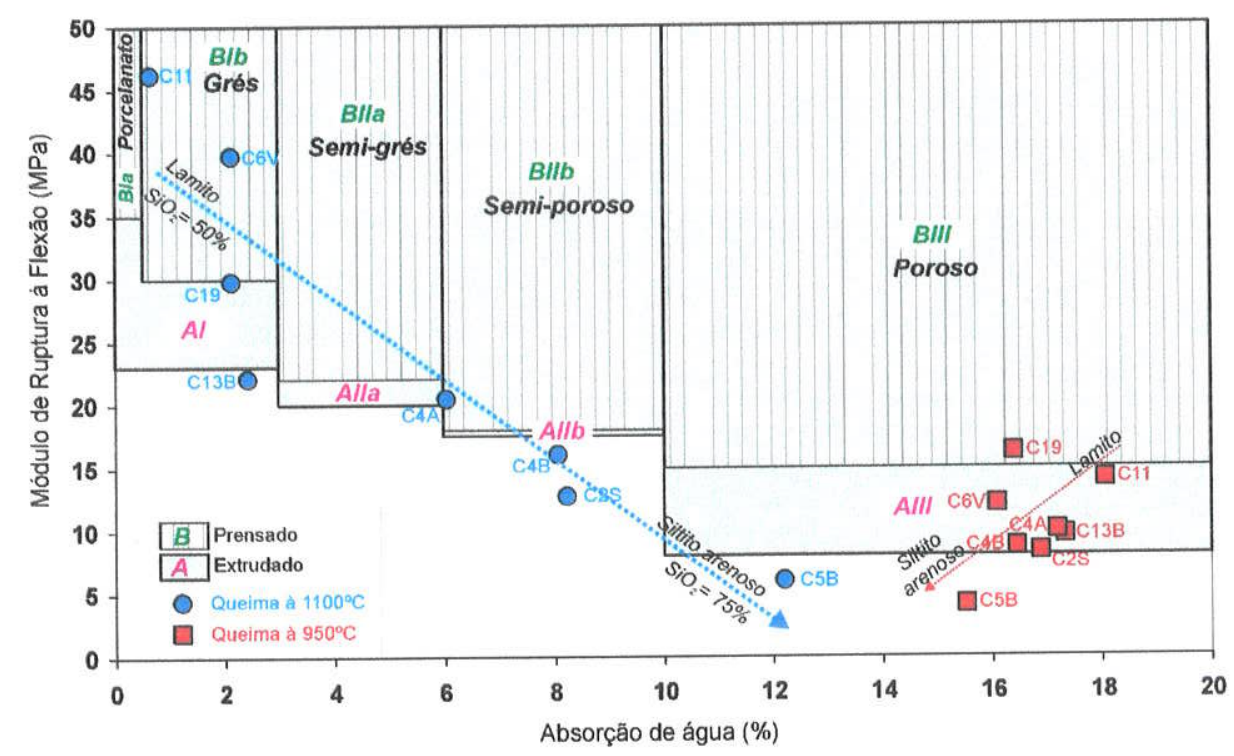

Figura 7.9: Classificação dos produtos de queima conforme recomendação da NBR13817 (ABNT, 1997), baseada em absorção de água e módulo de ruptura à flexão, para conformação por extrusão e por prensagem. (As setas representam as linhas de tendência obtidas para o conjunto de dados) 
$\mathrm{Na}$ temperatura de $950^{\circ} \mathrm{C}$ somente a amostra $\mathrm{C} 19$ apresentou conformidade com as especificações de um produto obtido por prensagem da classe BIII. As demais de lamitos não se mostraram em conformidade com a norma para produtos prensados, porém apresentariam propriedades satisfatórias se tivessem sido extrudidas. Para Florêncio (1999) as resistências mecânicas para produtos extrudidos são mais elevadas que para produtos prensados, devido ao grau de coesão das partículas. Tendo em vista essa observação, inferiu-se que em conformação por extrusão os resultados poderiam ser iguais ou superiores aos encontrados por prensagem.

Para a temperatura de $1100^{\circ} \mathrm{C}$, a classificação dos materiais variou em função das características já discutidas. Somente as amostras C11, C19 (lamitos) e C6V (lamito arenoso) apresentaram-se mais adequadas às especificações da classe Blb (grés), de placas cerâmicas conformadas por prensagem. As demais amostras apresentaram resultados um pouco inferiores às especificadas para a fabricação de semi-grés, semi-poroso e poroso.

Somando-se a avaliação prévia das propriedades plásticas das amostras naturais com a interpretação de resultados após queima, concluiu-se que os lamitos, lamitos arenosos e siltitos arenosos apresentaram características físicas interessantes, porém a utilização seria melhor conduzida se fossem adicionados às matérias primas convencionais (argilas comuns, quartzo, feldspato, etc.) a fim de se ressaltar as propriedades mais interessantes como a elevada plasticidade em formas naturais, e baixa absorção de água após queima.

\subsection{Ensaios pozolânicos}

As quatro amostras naturais representativas da área estudada - três lamitos (C5A, C11 e C19) e um lamito arenoso (C6V), e suas correspondentes calcinadas, foram submetidas aos ensaios de determinação dos índices de atividade pozolânica com cal e com cimento. Análises de difratometria de raios $X$ e microscopia eletrônica de varredura foram utilizadas para o monitoramento das transformações térmicas e químicas decorrentes.

A determinação das temperaturas de calcinação adequadas para a ativação térmica dos argilominerais apoiou-se em interpretação de curvas termodiferenciais, considerando-se que a temperatura de ativação ótima seria encontrada entre dois importantes marcos térmicos: a desidroxilação dos argilominerais (segundo pico endotérmico) e a cristalização de novas fases 
cristalinas (primeiro pico exotérmico) (Figura 7.10). Nesse intervalo de temperatura, entendeuse que haveria desarranjo das estruturas dos argilominerais, com a formação de fases amorfas.

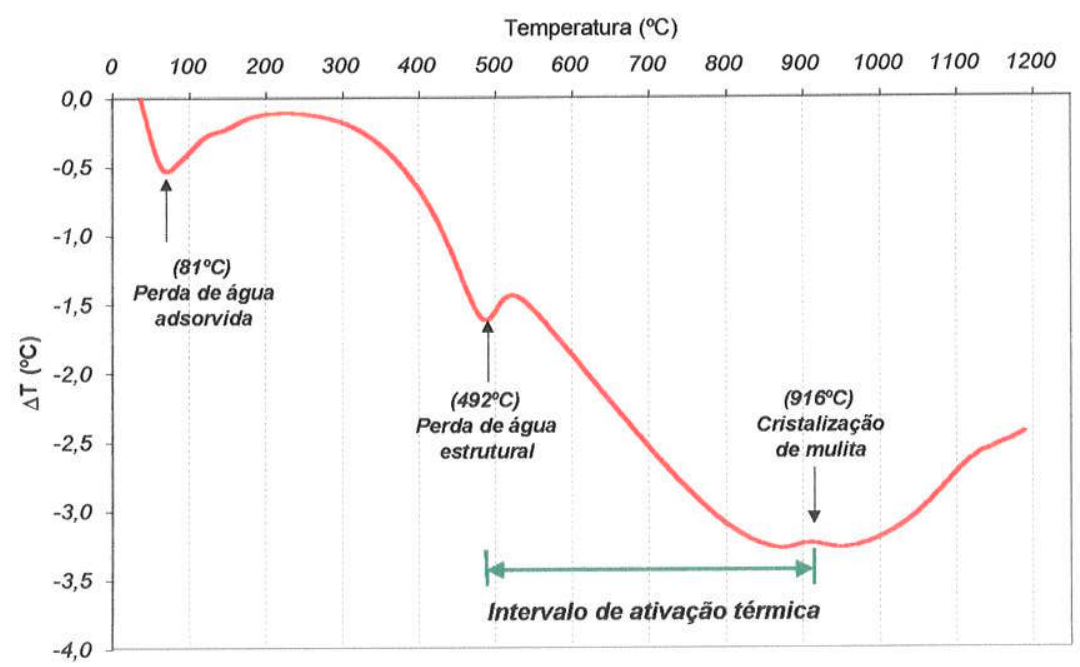

Figura 7.10: Curva termodiferencial típica das amostras esmectíticas estudadas (C11).

As curvas de análise termodiferencial (ATG) e termogravimétrica (ATG) apresentados nas Figuras 6.17 e 6.18 (Capítulo $\mathrm{VI}$ ) mostraram que, independentemente do litotipo estudado, tanto a desidroxilação, como a formação de novas fases cristalinas ocorreram em temperaturas semelhantes (Tabela 7.8).

Tabela 7.8: Reações e transformações térmicas de amostras de lamitos e lamito arenoso.

\begin{tabular}{|c|c|c|c|c|}
\hline \multirow{2}{*}{ Reações } & \multicolumn{2}{|c|}{ Temperatura $\left({ }^{\circ} \mathrm{C}\right)$} & \multirow{2}{*}{ Transformações } \\
\cline { 2 - 4 } & Lamito & Lamito arenoso & Perdas de água adsorvida \\
\cline { 2 - 4 } & \multirow{2}{*}{ endotérmicas } & 81,3 & 82,0 & $\begin{array}{c}\text { Perdas de água estrutural } \\
\text { (desidroxilação) }\end{array}$ \\
\cline { 2 - 4 } & 492,7 & 489,0 & Cristalização de novas fases \\
\hline
\end{tabular}

O intervalo entre 500 e $900^{\circ} \mathrm{C}$ foi o alvo definido para a ativação térmica, no qual foram selecionadas as temperaturas de $550,600,700$ e $850^{\circ} \mathrm{C}$ para investigação, com objetivo de determinar uma temperatura ótima de calcinação que propiciasse um melhor desempenho mecânico.

Somente algumas amostras foram selecionadas para as determinações de atividade pozolânica com cal e cimento, aquelas mais argilosas e representativas dos pacotes sedimentares observados em campo. O sumário dos ensaios executados para cada uma das 4 amostras ensaiadas é apresentado na Tabela 7.9. 
Tabela 7.9: Amostras selecionadas para as determinações de atividade pozolânica com cal e cimento.

\begin{tabular}{|c|c|c|c|c|c|}
\hline \multirow{3}{*}{$\begin{array}{l}\text { Temperatura } \\
\text { de ensaio }\left({ }^{\circ} \mathrm{C}\right)\end{array}$} & \multirow{3}{*}{ Ensaio } & \multicolumn{4}{|c|}{ Material pozolânico } \\
\hline & & \multicolumn{3}{|c|}{ Lamito } & $\begin{array}{l}\text { Lamito } \\
\text { arenoso }\end{array}$ \\
\hline & & C5A & $\mathrm{C} 11$ & C19 & $\mathrm{C6V}$ \\
\hline \multirow{2}{*}{ Natural } & Cal & $x$ & $x$ & nd. & $x$ \\
\hline & Cimento & nd. & $x$ & nd. & nd. \\
\hline \multirow{2}{*}{550} & Cal & $x$ & $x$ & nd. & nd. \\
\hline & Cimento & nd. & $x$ & nd. & nd. \\
\hline \multirow{2}{*}{600} & Cal & $x$ & $x$ & $x$ & $x$ \\
\hline & Cimento & nd. & $x$ & $x$ & $x$ \\
\hline \multirow{2}{*}{700} & Cal & $x$ & $x$ & nd. & nd. \\
\hline & Cimento & nd. & nd. & nd. & nd. \\
\hline \multirow{2}{*}{850} & Cal & nd. & $x$ & $x$ & $x$ \\
\hline & Cimento & nd. & $x$ & $x$ & $x$ \\
\hline
\end{tabular}

$x$ - índice determinado; $n d$ - indice não determinado

\subsection{1 Índice de atividade pozolânica com cal}

Para determinação do índice de atividade pozolânica com cal foram determinados os parâmetros: massa específica, área específica e resíduo na peneira de $45 \mu \mathrm{m}$ (Tabela 7.10).

Tabela 7.10: Propriedades fisicas das amostras naturais e calcinadas.

\begin{tabular}{|c|c|c|c|c|c|}
\hline \multirow{3}{*}{ Propriedade } & \multirow{3}{*}{ Temperatura $\left({ }^{\circ} \mathrm{C}\right)$} & \multicolumn{4}{|c|}{ Material pozolânico } \\
\hline & & Lamito arenoso & & Lamito & \\
\hline & & $\mathrm{C6V}$ & C5A & C11 & C19 \\
\hline \multirow{5}{*}{$\begin{array}{c}\text { Massa específica } \\
\left(\mathrm{g} / \mathrm{cm}^{3}\right)\end{array}$} & natural & 2,61 & 2,59 & 2,57 & nd. \\
\hline & 550 & nd. & 2,56 & 2,62 & nd. \\
\hline & 600 & 2,64 & 2,62 & 2,60 & 2,63 \\
\hline & 700 & nd. & 2,61 & 2,61 & nd. \\
\hline & 850 & 2,71 & nd. & 2,65 & 2,71 \\
\hline \multirow{5}{*}{$\begin{array}{l}\text { Área especifica } \\
\qquad\left(\mathrm{cm}^{2} / \mathrm{g}\right)\end{array}$} & natural & 11900 & 10190 & 10000 & nd. \\
\hline & 550 & nd. & 10220 & 11690 & nd. \\
\hline & 600 & 11580 & 10880 & 11160 & 10030 \\
\hline & 700 & nd. & 11030 & 11740 & nd. \\
\hline & 850 & 10480 & nd. & 9370 & 9090 \\
\hline \multirow{5}{*}{$\begin{array}{c}\text { Resíduo na } \\
\text { peneira de } \\
45 \mu \mathrm{m}(\%)\end{array}$} & natural & 12,9 & 18,4 & 19,0 & nd. \\
\hline & 550 & nd. & 19,4 & 19,8 & nd. \\
\hline & 600 & 18,9 & 19,1 & 16,8 & 19,5 \\
\hline & 700 & nd. & 19,3 & 17,8 & nd. \\
\hline & 850 & 19,9 & nd. & 18,6 & 19,7 \\
\hline
\end{tabular}

nd. - não determinado. 
A composição das argamassas foi definida segundo as recomendações da NBR 5751 (ABNT, 1992b), como apresentado na Tabela 7.11.

Tabela 7.11: Composição das argamassas para a determinação de atividade pozolânica com cal aos 7 dias de cura.

\begin{tabular}{|c|c|c|c|c|c|c|}
\hline \multirow{3}{*}{\multicolumn{2}{|c|}{ Materiais }} & \multirow{3}{*}{ Temperatura $\left({ }^{\circ} \mathrm{C}\right)$} & \multicolumn{4}{|c|}{ Material pozolânico } \\
\hline & & & \multirow{2}{*}{$\begin{array}{l}\text { Lamito } \\
\text { arenoso } \\
\mathrm{C} 6 \mathrm{~V}\end{array}$} & \multicolumn{3}{|c|}{ Lamito } \\
\hline & & & & C5A & C11 & C19 \\
\hline \multirow{14}{*}{$\frac{\widehat{D}}{\frac{0}{\mathbb{D}}}$} & Areia & & 936,0 & 936,0 & 936,0 & 936,0 \\
\hline & Cal & & 104,0 & 104,0 & 104,0 & 104,0 \\
\hline & & & & & & \\
\hline & \multirow{5}{*}{ Pozolana } & natural & 242,4 & 240,5 & 238,6 & nd. \\
\hline & & 550 & nd. & 237,7 & 243,3 & nd. \\
\hline & & 600 & 245,1 & 243,3 & 241,4 & 244,2 \\
\hline & & 700 & nd. & 242,4 & 242,4 & nd. \\
\hline & & 850 & 251,6 & nd. & 246,0 & 251,6 \\
\hline & \multicolumn{6}{|c|}{ (1) } \\
\hline & \multirow{5}{*}{ Água (1) } & natural & 384,0 & 386,0 & 410,0 & nd. \\
\hline & & 550 & nd. & 294,0 & 293,0 & nd. \\
\hline & & 600 & 290,0 & 290,0 & 285,0 & 285,0 \\
\hline & & 700 & nd. & 280,0 & 282,0 & nd. \\
\hline & & 850 & 266,0 & nd. & 265,0 & 266,0 \\
\hline
\end{tabular}

(1) Quantidade de água necessária para produzir argamassas com índice de consistência de $(225 \pm 5) \mathrm{mm}$ determinada de acordo com a NBR7215. (nd. - não determinado)

Após os sete dias de cura foram determinados os índices de atividade pozolânica com cal nos corpos-de-prova, o qual é definido pela resistência mecânica à compressão (Tabela 7.12). Os indices de atividade obtidos superaram o valor mínimo de resistência mecânica à compressão (6MPa), estabelecido pela NBR 12653/92 (ABNT, 1992a) em 17 a $77 \%$.

Tabela 7.12: Indice de atividade pozolânica com cal aos 7 dias de cura.

\begin{tabular}{||c|c|c|c|c|c|}
\hline \multirow{4}{*}{$\begin{array}{c}\text { Tindice de Atividade Pozolânica } \\
\text { Temperatura }\left({ }^{\circ} \mathbf{C}\right)\end{array}$} & $\begin{array}{c}\text { Lamito } \\
\text { arenoso }\end{array}$ & \multicolumn{4}{|c|}{ Lamito } \\
\cline { 3 - 6 } com cal (MPa) & & $\mathbf{C 6 V}$ & $\mathbf{C 5 A}$ & $\mathbf{C 1 1}$ & $\mathbf{C 1 9}$ \\
\cline { 2 - 6 } & natural & 0,0 & 1,6 & 0,0 & nd. \\
\cline { 2 - 6 } & 550 & nd. & 7,2 & 8,1 & nd. \\
\cline { 2 - 6 } & 600 & 10,1 & 9,1 & 9,6 & 8,5 \\
\cline { 2 - 6 } & 700 & nd. & 10,6 & 10,0 & nd. \\
\cline { 2 - 6 } & 850 & 7,8 & nd. & 7,6 & 7,0 \\
\hline
\end{tabular}

nd. - não determinado; ${ }^{(1)}$ Média de três corpos-de-prova. 
As amostras naturais apresentaram pouca ou nenhuma aptidão ao aproveitamento pozolânico devido à propriedade expansiva da esmectita, que refletiu na elaboração das argamassas pelo grande volume de água requerida, e também na resistência mecânica dos corpos-de-prova, devido ao fissuramento provocado pela expansão. A propriedade expansiva da esmectita foi sensivelmente reduzida pela calcinação, como pôde ser notada na preparação das argamassas com cal, pela redução em $30-35 \%$ da água requerida comparativamente às amostras naturais.

Das 4 amostras ensaiadas, o melhor resultado de resistência mecânica foi observado na amostra C6V. Atribui-se à presença de esmectita e illita o desempenho da amostra C5A um pouco inferior ao da amostra $\mathrm{C6V}$, apesar de tê-la superado quando calcinada à $700^{\circ} \mathrm{C}$ (Figura 7.11 ).

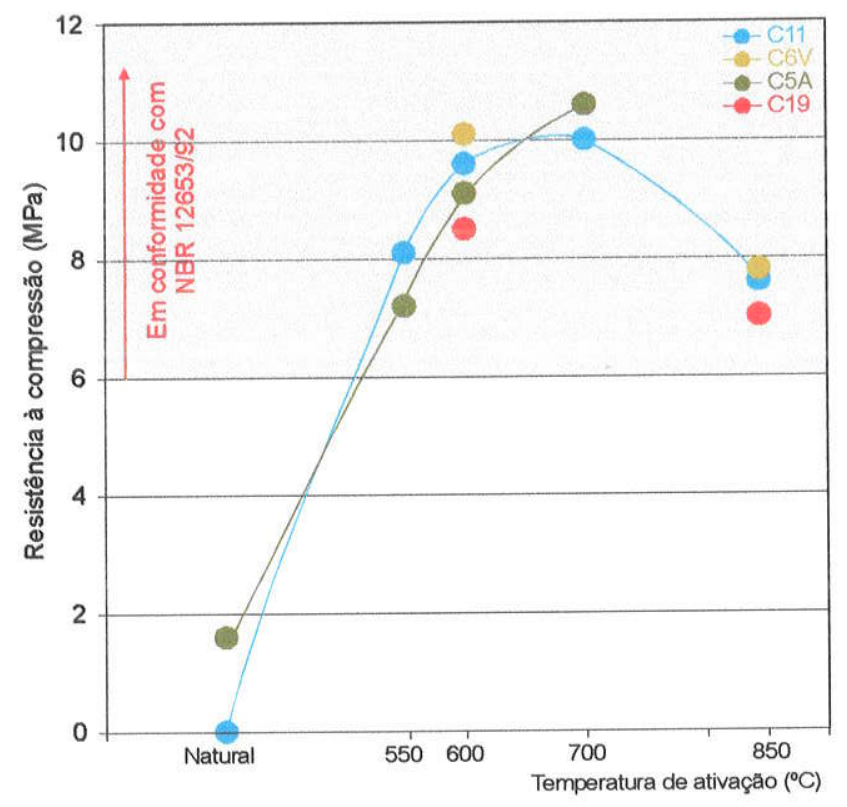

Figura 7.11: Resultados de resistências mecânicas (índice de atividade pozolânica com cal) para amostras naturais e calcinadas

A justificativa aventada para os resultados superiores da amostra C6V apoiou-se na composição mineralógica. Enquanto que a amostra C6V continha 50\% de caulinita, as demais, apesar de terem caulinita (30\%), apresentaram teores elevados de esmectita $(50 \%)$, o que deve ter contribuído para a redução dos índices de atividade pozolânica, devido à menor reatividade química desse argilomineral. Assim, supõe-se que deve ter havido muito hidróxido de cálcio em excesso em amostras mais esmectíticas que foi recristalizado na 
forma de portlandita, que segundo Zampieri (1989) colabora negativamente para a resistência mecânica do concreto.

A queda das resistências mecânicas para todas as amostras na temperatura de $850^{\circ} \mathrm{C}$ se justificaria pelo início da nucleação de mulita, cuja organização cristalina reduz sensivelmente a reatividade química. Essa nucleação foi notada na difração de raios $X$ (DRX), apresentada na Figura 7.12, e foi corroborada pelo aumento nas massas específicas e diminuição das áreas específicas dos materiais (Figura 7.13).

Os difratogramas de amostras calcinadas mostraram que na temperatura de $600^{\circ} \mathrm{C}$, a estrutura da caulinita foi totalmente destruída, com ausência das reflexões basais (001) e (002) a 7,0 e $3,5 \AA$, respectivamente. Tanto na temperatura de 600 como na de $850^{\circ} \mathrm{C}$, foi reconhecido um pico à $10 \AA$, referente à esmectita após desidroxilação e à reflexão basal da illita, ainda preservada. Há, para as duas temperaturas de calcinação, sugestiva presença de material amorfo, evidenciada pelo suave abaulamento do perfil difratométrico entre 18 e $422 \theta$ (Figura 7.12).

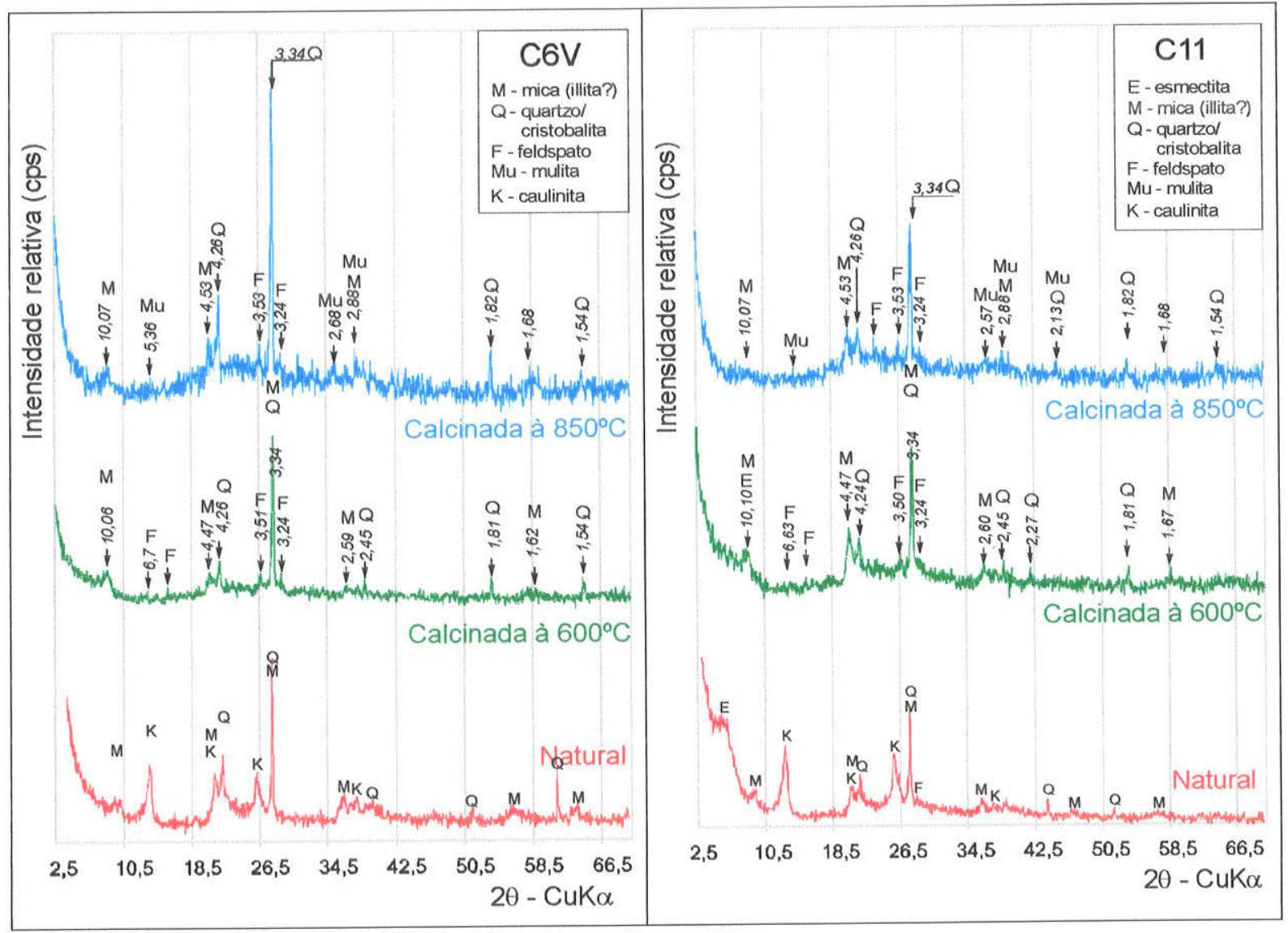

Figura 7.12: Difratogramas das amostras C6V e C11 na forma natural, calcinadas à 600 e $850^{\circ} \mathrm{C}$. 


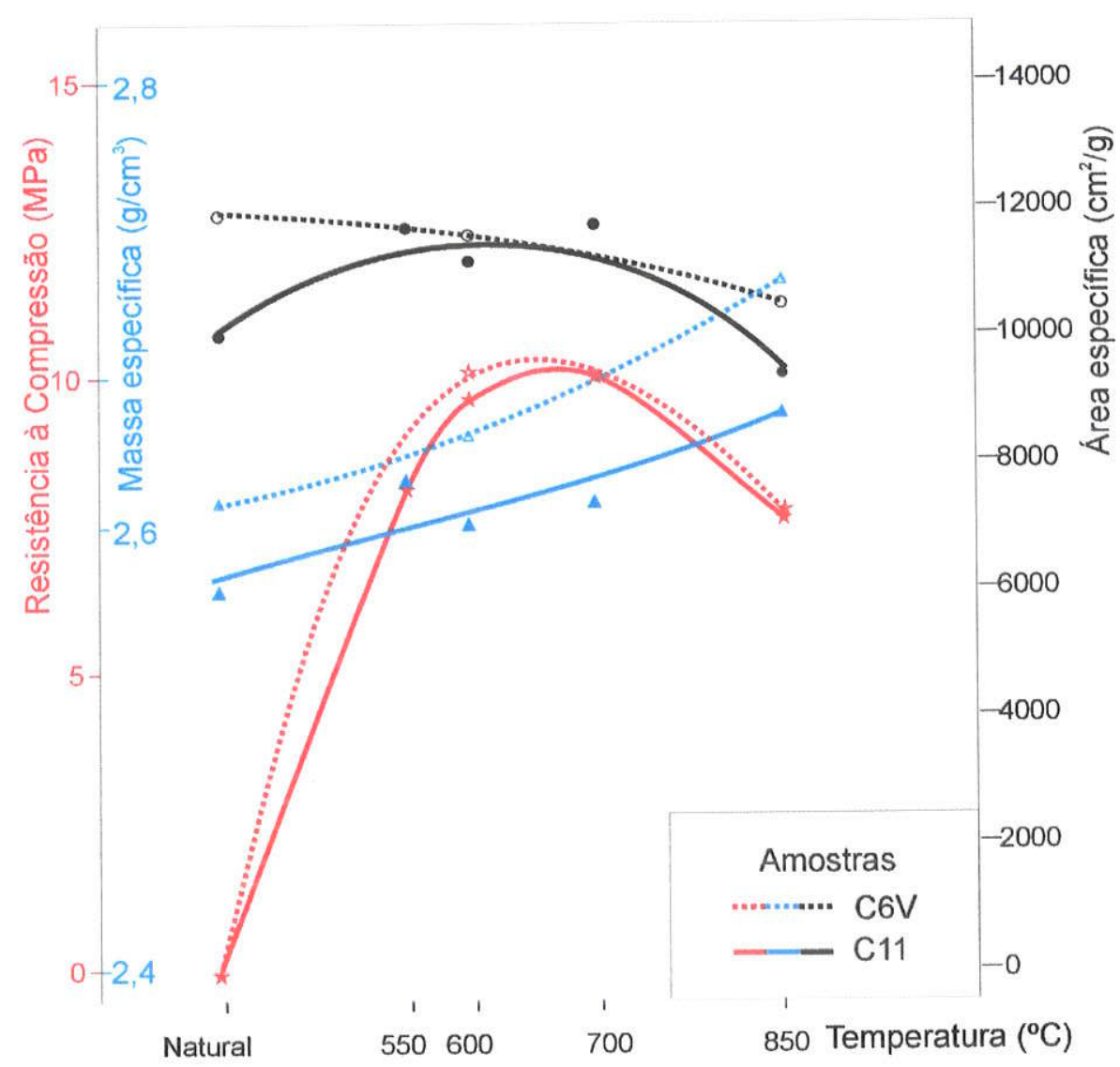

Figura 7.13: Influência da área específica e da massa específica sobre a resistência mecânica em função da temperatura de ativação

A atividade pozolânica com cal medida para as diferentes temperaturas descreveu graficamente uma tendência parabólica, com a temperatura ótima de ativação térmica em $700^{\circ} \mathrm{C}$, ponto a partir da qual verificou-se o decréscimo dos índices (Figura 7.13).

Foram efetuadas análises por DRX em fragmentos dos corpos-de-prova aos 7 dias de cura na perspectiva de identificar as fases cristalinas produzidas pela reação pozolânica entre o hidróxido de cálcio e os lamitos (Prancha 7.2 e 7.3). 

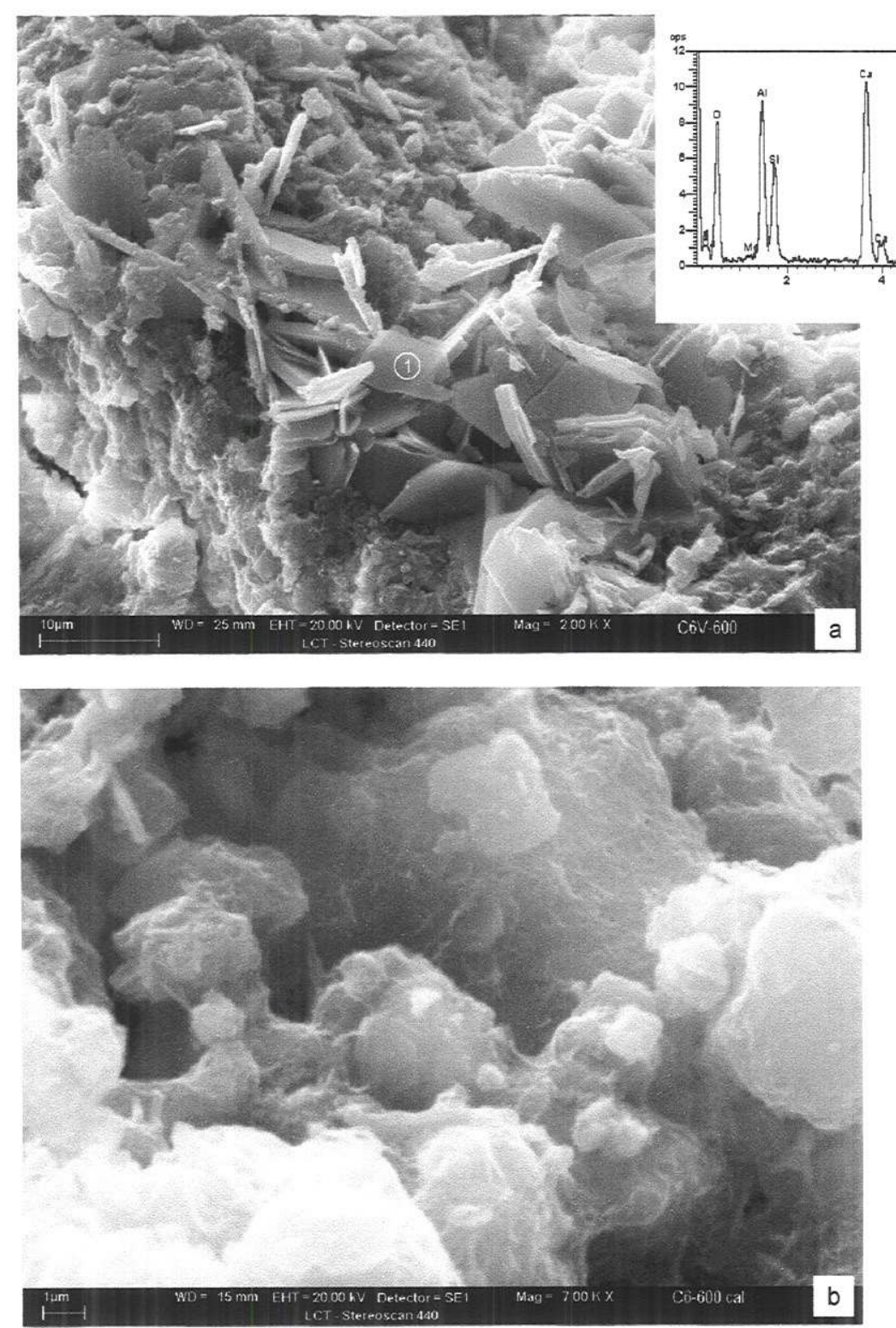

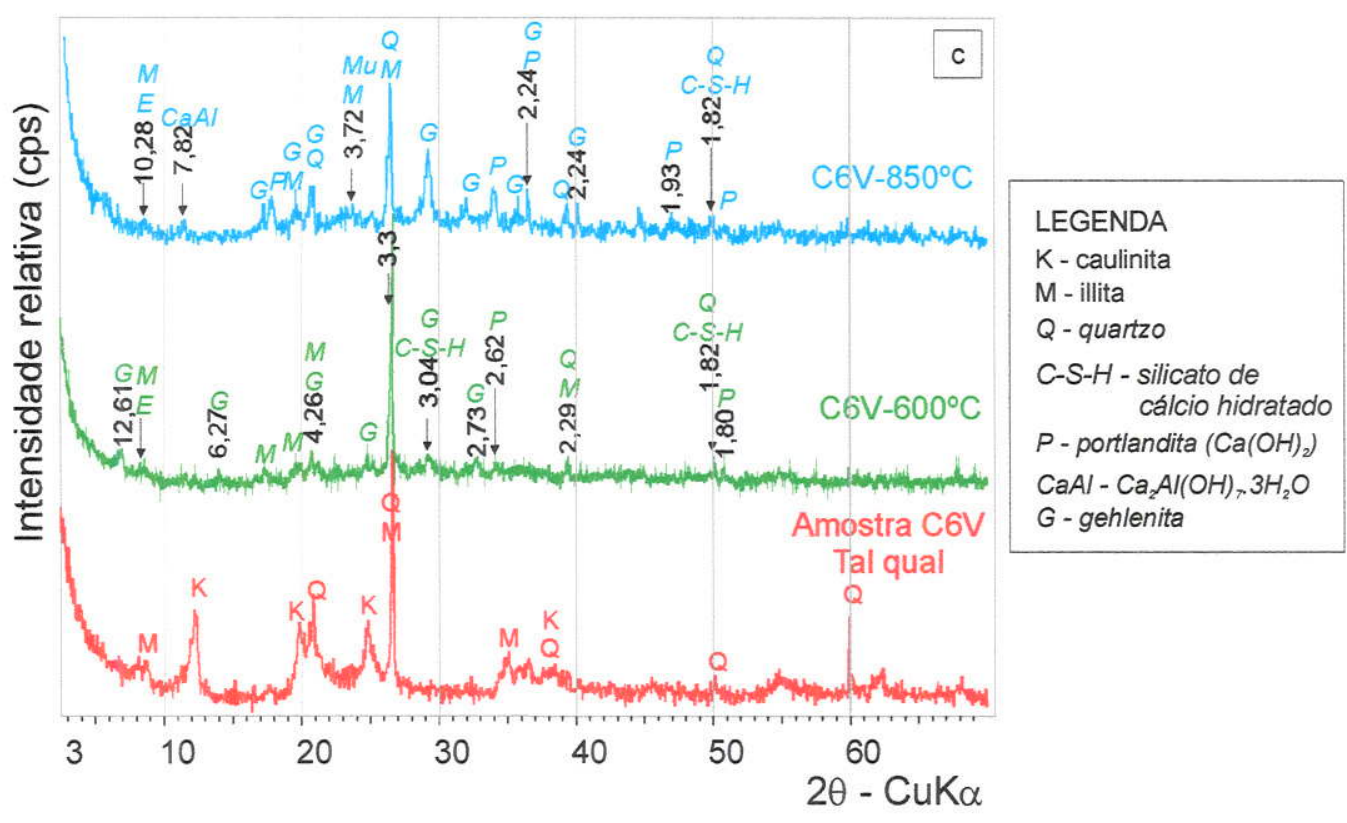

Prancha 7.2: Imagens de microscopia eletrônica de varredura: (a) fase neoformada a partir da reação pozolânica (placóide - gehlenita ?; rendilhado - C-S-H), com espectro de EDS para o ponto circundado; (b) material rendilhado recobrindo as placas de argilominerais; (c) difratogramas de raios X obtidos para amostras em estado natural e das misturas amostra+hidróxido de cálcio para as temperaturas de 600 e $850^{\circ} \mathrm{C}$ (amostra $\mathrm{C} 6 \mathrm{~V}+\mathrm{Ca}(\mathrm{OH})_{2}$ aos 7 dias de cura) 

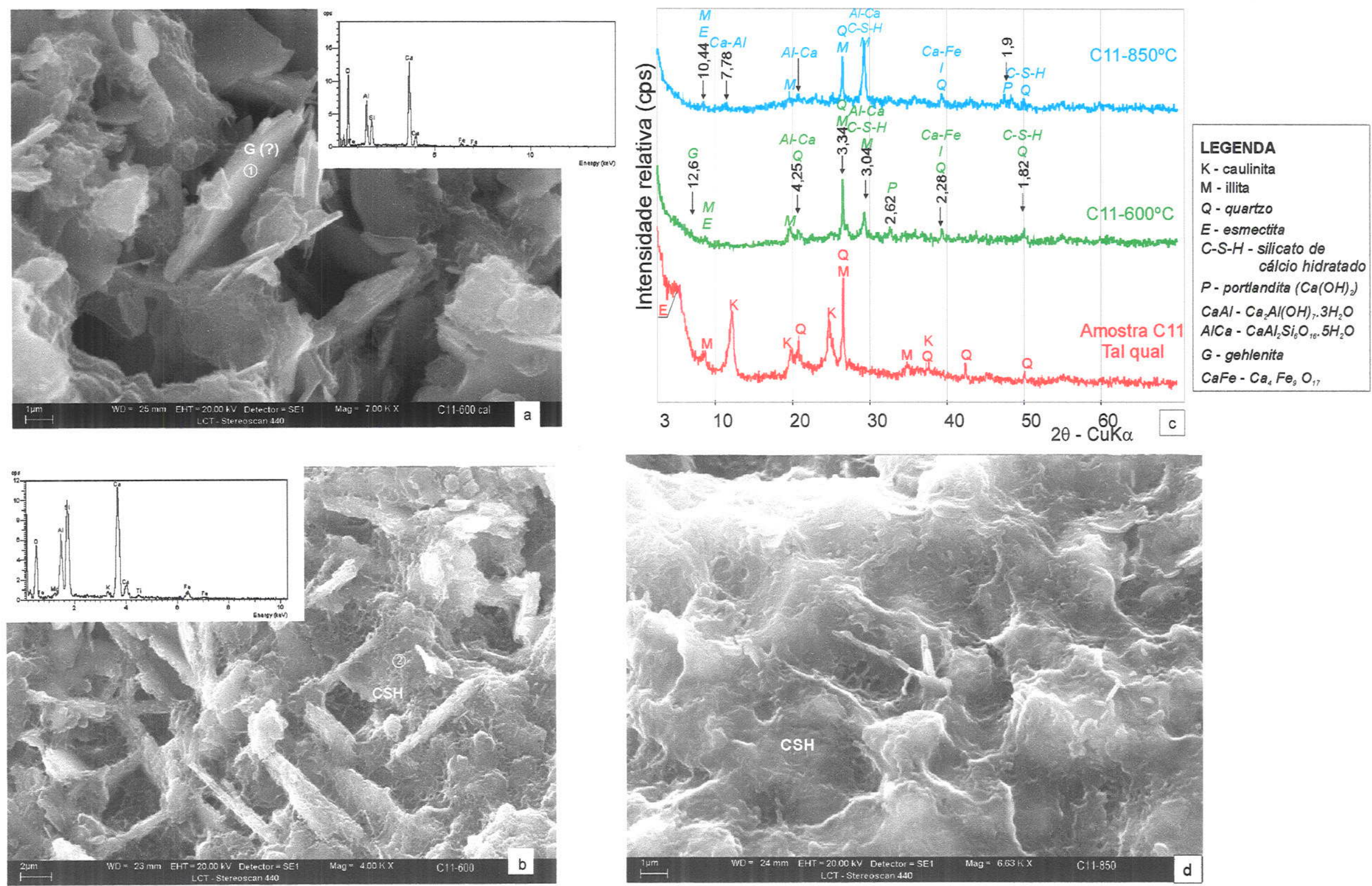

Prancha 7.3: Imagens de microscopia eletrônica de varredura: (a)fase neoformada a partir da reação pozolânica (placóide - gehlenita ?; rendilhado - CSH), com espectro de EDS para o ponto circundado; (b) material rendilhado recobrindo as placas de argilominerais, com espectro de EDS para o ponto circundado; (c) difratogramas de raios $\mathrm{X}$ obtidos para amostras em estado natural e das misturas amostra+hidróxido de cálcio para as temperaturas de 600 e $850^{\circ} \mathrm{C}$; (d) aspecto geral da pasta cal/pozolana (amostra $\mathrm{C} 11+\mathrm{Ca}(\mathrm{OH})_{2}$ aos 7 dias de cura) 
Os produtos da reação química entre a amostra $\mathrm{C} 6 \mathrm{~V}$-calcinada à $600^{\circ} \mathrm{C}$ e o $\mathrm{Ca}(\mathrm{OH})_{2}$, foram gehlenita $\left(\mathrm{Ca}_{2} \mathrm{Al}_{2} \mathrm{SiO}_{7} .8 \mathrm{H}_{2} \mathrm{O}\right)$, portlandita $\left(\mathrm{Ca}(\mathrm{OH})_{2}\right)$ e silicato de cálcio hidratado (C-S-H). Para a reação com a amostra calcinada à $850^{\circ} \mathrm{C}$, foram reconhecidas as mesmas fases e mais um carboaluminato hidratado. Ao MEV, o C-S-H e a gehlenita foram reconhecidos pelos hábitos rendilhado e placóide, respectivamente.

A reação entre a amostra $\mathrm{C} 11$-calcinada à $600^{\circ} \mathrm{C}$ e o Ca(OH $)_{2}$ foi menos intensa que a da amostra C6V, evidenciada em DRX e confirmadas ao MEV, pela pequena ocorrência de cristais de gehlenita. $\mathrm{Na}$ reação pozolânica com a amostra calcinada à $850^{\circ} \mathrm{C}$, foram identificados aluminossilicato de cálcio hidratado $\left(\mathrm{CaAl}_{2} \mathrm{Si}_{6} \mathrm{O}_{16} \cdot 5 \mathrm{H}_{2} \mathrm{O}\right)$, óxido de ferro e cálcio $\left(\mathrm{Ca}_{4} \mathrm{Fe}_{9} \mathrm{O}_{17}\right)$, carboaluminato hidratado $\left(\mathrm{Ca}_{2} \mathrm{Al}(\mathrm{OH})_{7} \cdot 3 \mathrm{H}_{2} \mathrm{O}\right)$ e silicato de cálcio hidratado $(\mathrm{C}-\mathrm{S}-\mathrm{H})$, sendo as duas primeiras fases diferentes daquelas obtidas para a amostra C6V calcinada à mesma temperatura.

Os maiores desempenhos mecânicos observados na amostra C6V puderam ser atribuídos à composição caulinítica, que permitiu o melhor desenvolvimento da reação pozolânica. No caso dos lamitos de composição esmectítica, a reação não ocorreu da mesma forma. Os resultados corroboram a observação de Zampieri (1989), de que as maiores resistências mecânicas estavam associadas ao predomínio de gehlenita e silicatos de cálcio hidratados sobre carboaluminato hidratado. Esse fato também deve ter contribuído para a obtenção dos melhores indices de atividade pozolânica com cal, observados para as amostras calcinadas em temperaturas inferiores à $850^{\circ} \mathrm{C}$.

\subsection{2 Índice de atividade pozolânica com cimento}

Além da determinação da atividade pozolânica com cal, foram determinadas as atividades pozolânicas com cimento aos 28 dias de cura, segundo NBR 5752/92 (ABNT, 1992c). Houve a caracterização física prévia das matérias-primas e do cimento utilizado na preparação das argamassas, conforme apresentado na Tabela 7.13.

Conforme recomendação da NBR 7215/96 (ABNT, 1996), foram preparados para cada argamassa três corpos-de-prova com adição de pozolana e um sem adição para a argamassa de referência. Para a determinação do índice de atividade pozolânica com cimento, a NBR 5752/92 recomenda que a argamassa (B) deve ter $35 \%$ do seu volume absoluto de cimento substituído por material pozolânico (Tabela 7.14). 
Tabela 7.13: Caracterização física dos materiais pozolânicos e do cimento utilizado nos ensaios.

\begin{tabular}{|c|c|c|c|c|c|}
\hline \multirow{3}{*}{ Propriedade } & \multirow{3}{*}{ Temperatura $\left({ }^{\circ} \mathrm{C}\right)$} & \multicolumn{3}{|c|}{ Material pozolânico } & \multirow{3}{*}{$\begin{array}{l}\text { Cimento } \\
\text { CP-II-F-32 }\end{array}$} \\
\hline & & \multirow{2}{*}{$\begin{array}{c}\text { Lamito } \\
\text { arenoso } \\
\mathrm{C} 6 \mathrm{~V}\end{array}$} & \multicolumn{2}{|c|}{ Lamito } & \\
\hline & & & C11 & C19 & \\
\hline \multirow{4}{*}{$\begin{array}{c}\text { Massa especifica } \\
\left(\mathrm{g} / \mathrm{cm}^{3}\right)\end{array}$} & natural & nd. & 2,57 & nd. & \multirow{4}{*}{3,10} \\
\hline & 550 & nd. & 2,62 & nd. & \\
\hline & 600 & 2,64 & 2,60 & 2,63 & \\
\hline & 850 & 2,71 & 2,65 & 2,71 & \\
\hline \multirow{4}{*}{$\begin{array}{l}\text { Área específica } \\
\qquad\left(\mathrm{cm}^{2} / \mathrm{g}\right)\end{array}$} & natural & nd. & 10000 & nd. & \multirow{4}{*}{3340} \\
\hline & 550 & nd. & 11690 & nd. & \\
\hline & 600 & 11580 & 11160 & 10030 & \\
\hline & 850 & 10480 & 9370 & 9090 & \\
\hline \multirow{4}{*}{ 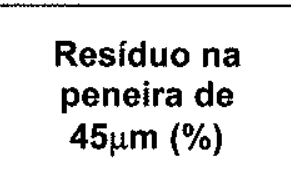 } & natural & nd. & 19,0 & nd. & \multirow{4}{*}{11,4} \\
\hline & 550 & nd. & 19,8 & nd. & \\
\hline & 600 & 18,9 & 16,8 & 19,5 & \\
\hline & 850 & 19,9 & 18,6 & 19,7 & \\
\hline
\end{tabular}

nd. não de terminado

Tabela 7.14: Composição das argamassas com cimento Portland.

\begin{tabular}{|c|c|c|c|c|c|c|}
\hline \multirow{2}{*}{\multicolumn{2}{|c|}{ Materiais }} & \multirow{3}{*}{ Temperatura $\left({ }^{\circ} \mathrm{C}\right)$} & \multirow{3}{*}{$\begin{array}{c}\text { Cimento } \\
\text { (A) }\end{array}$} & \multicolumn{3}{|c|}{ Material pozolânico (B) } \\
\hline & & & & \multirow{2}{*}{$\begin{array}{c}\text { Lamito } \\
\text { arenoso } \\
\text { C6V }\end{array}$} & \multicolumn{2}{|c|}{ Lamito } \\
\hline & & & & & $\mathrm{C11}$ & C19 \\
\hline \multirow{10}{*}{ 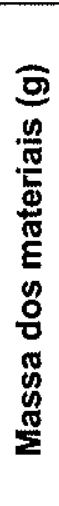 } & $\mathrm{CP} \| 1-\mathrm{F}-32$ & & 312,0 & 202,8 & 202,8 & 202,8 \\
\hline & Areia & & 936,0 & 936,0 & 936,0 & 936,0 \\
\hline & \multirow{4}{*}{ Pozolana } & natural & 0,0 & nd. & 91,1 & nd. \\
\hline & & 550 & 0,0 & nd. & 92,9 & nd. \\
\hline & & 600 & 0,0 & 93,0 & 91,6 & 92,6 \\
\hline & & 850 & 0,0 & 95,5 & 93,3 & 95,5 \\
\hline & \multirow{4}{*}{ Água (1) } & natural & 178,0 & nd. & 251,0 & nd. \\
\hline & & 550 & 178,0 & nd. & 207,0 & nd. \\
\hline & & 600 & 179,0 & 201,0 & 200,0 & 201,0 \\
\hline & & 850 & 179,0 & 196,0 & 196,0 & 197,0 \\
\hline
\end{tabular}

(1) Quantidade de água necessária para produzir argamassas com índice de consistência de (225 \pm 5$) \mathrm{mm}$ determinada de acordo com a NBR7215/96 (ABNT, 1996).

Os resultados dos índices de atividade pozolânica com cimento, obtidos para amostras calcinadas a $600^{\circ} \mathrm{C}$, mostraram-se próximos do limite de $75 \%$ especificado pela NBR $12653 / 92$ (ABNT,1992a). Para as amostras calcinadas a $850^{\circ} \mathrm{C}$, (C11 e C19) os resultados superaram em até $17 \%$ o índice mínimo requerido de $75 \%$, conforme indicado na Tabela 7.15. 
Tabela 7.15: Resultados das determinações da atividade pozolânica com cimento aos 28 dias de cura.

\begin{tabular}{|c|c|c|c|c|c|}
\hline \multirow{3}{*}{ Propriedade } & \multicolumn{5}{|c|}{ Identificação das argamassas } \\
\hline & (A) & & (B) & & \\
\hline & Cimento-CP II-F-32 & Temperatura $\left({ }^{\circ} \mathrm{C}\right)$ & C6V & C11 & C19 \\
\hline \multirow{4}{*}{$\begin{array}{c}\text { Resistência à } \\
\text { Compressãá } \\
\text { (MPa) }^{(1)}\end{array}$} & 30,6 & Natural & nd. & 11,5 & nd. \\
\hline & 30,3 & 550 & nd. & 22,5 & nd. \\
\hline & 34,0 & 600 & 26,5 & 25,2 & 24,4 \\
\hline & 34,0 & 850 & 29,6 & 29,5 & 28,5 \\
\hline \multirow{4}{*}{$\begin{array}{c}\text { Indice de Atividade } \\
\text { Pozolânica com } \\
\text { Cimento Portland } \\
(\%)\end{array}$} & & Natural & nd. & 36,7 & nd. \\
\hline & & 550 & nd. & 74,3 & nd. \\
\hline & & 600 & 77,9 & 74,1 & 71,8 \\
\hline & & 850 & 87,1 & 86,8 & 83,8 \\
\hline \multirow{4}{*}{$\begin{array}{c}\text { Água requerida } \\
(\%)\end{array}$} & & Natural & nd. & 141,0 & nd. \\
\hline & & 550 & nd. & 116,3 & nd. \\
\hline & & 600 & 112,3 & 111,7 & 112,3 \\
\hline & & 850 & 109,5 & 109,5 & 110,1 \\
\hline
\end{tabular}

${ }^{\pi}$ Média de três corpos-de-prova; nd. năo determinado.

Considerando as pozolanas obtidas a partir de lamitos calcinados nas temperaturas $600 \mathrm{e}$ $850^{\circ} \mathrm{C}$, a amostra $\mathrm{C} 6 \mathrm{~V}$ foi a que apresentou os melhores resultados, refletindo, novamente, uma composição mineralógica pobre em esmectita, como foi observado nos valores dos índices de atividade pozolânica com cal. Por outro lado, as amostras com esmectita calcinadas à temperatura de $850^{\circ} \mathrm{C}$ apresentaram índices de atividade em conformidade com a especificação (Figura 7.14).

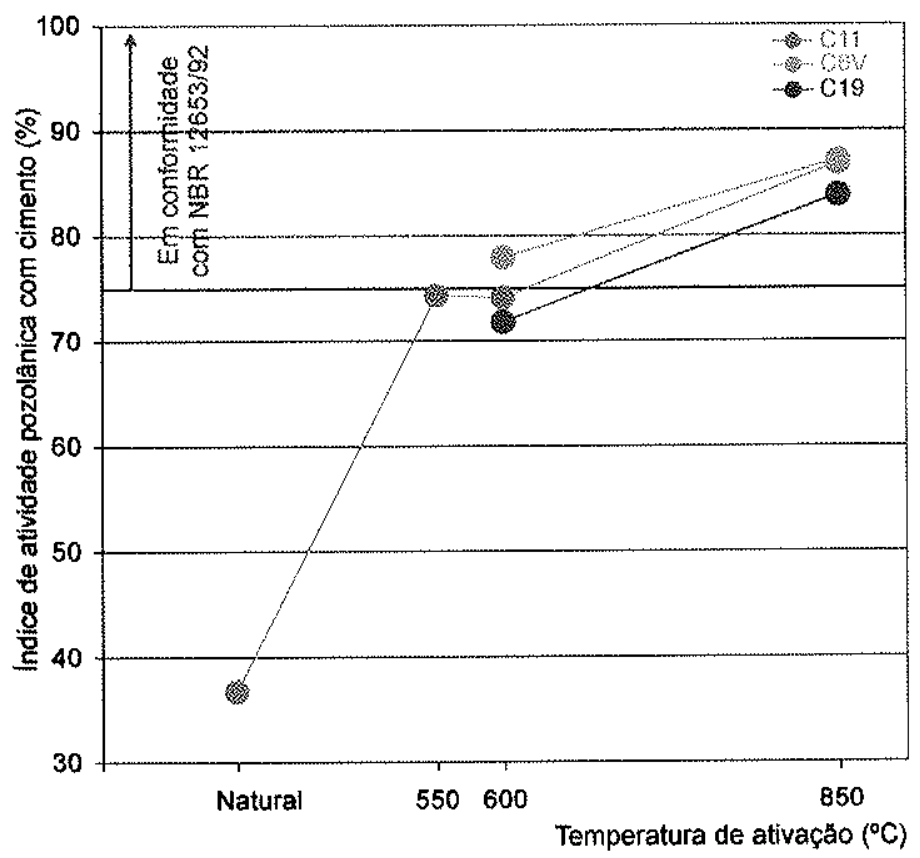

Figura 7.14: Resultados dos índices de atividade pozolânica em função da temperatura de ativação dos lamitos 


\subsubsection{Considerações gerais sobre os ensaios pozolânicos}

A princípio, como reportado na literatura, esperava-se que os índices de atividade pozolânica com cal aumentassem em proporção direta com a elevação da temperatura, porém os resultados obtidos contrariaram a expectativa inicial (Figura 7.15).

Comparando-se os resultados dos índices de atividade pozolânica com cal, aos 7 dias de cura, com os índices com cimento, aos 28 dias de cura, observou-se que as amostras submetidas à temperatura de calcinação de $850^{\circ} \mathrm{C}$, apresentaram resultados menores que os obtidos em temperaturas inferiores no primeiro ensaio, e maiores, no segundo ensaio.

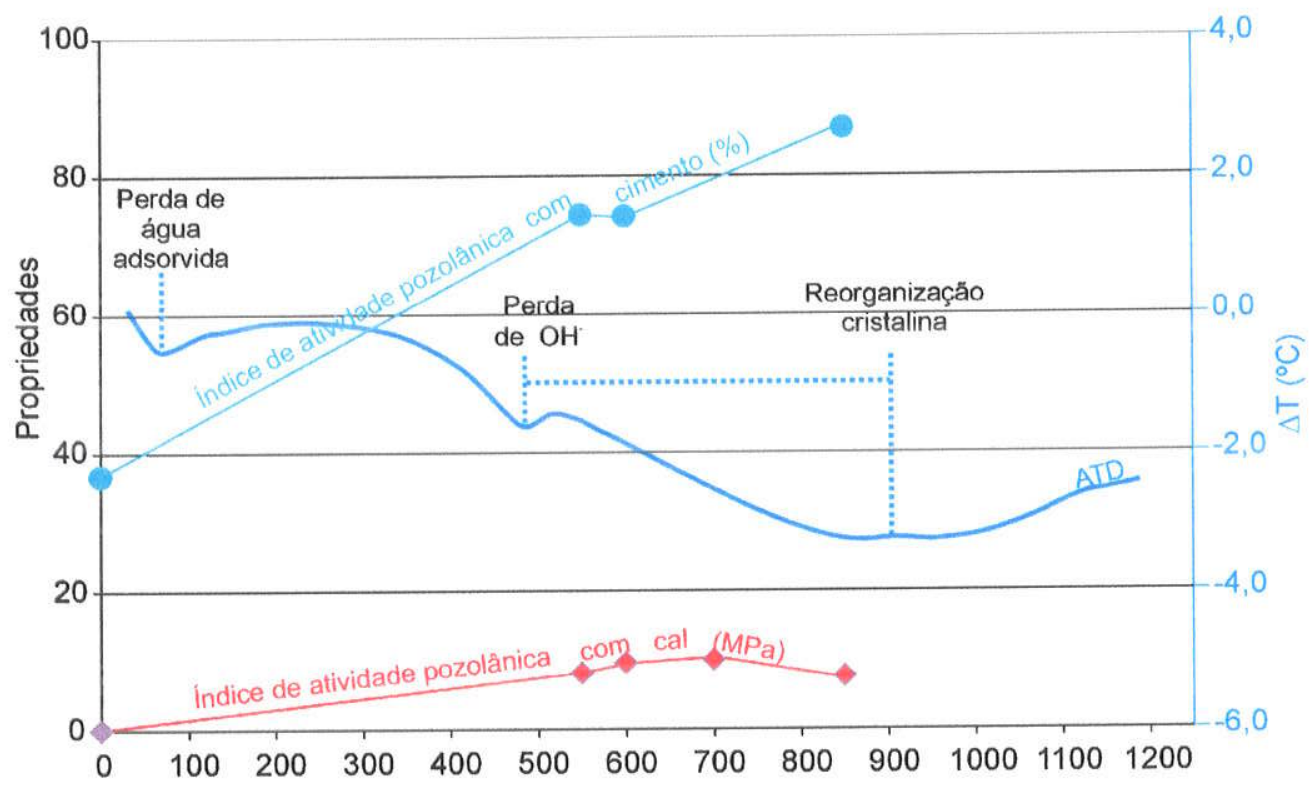

Figura 7.15: Índices de atividade pozolânica com cal (7 dias de cura), com cimento (28 dias de cura) e curva termodiferencial do lamito (exemplo C11)

A queda dos índices de atividade pozolânica com cal, aos 7 dias de cura, para todas as amostras calcinadas à $850^{\circ} \mathrm{C}$, foi entendida como resultado da incipiente nucleação da mulita, cuja reatividade química é menor que a da metacaulinita. Com a presença de um material menos reativo nas amostras, haveria um excesso de hidróxido de cálcio que é recristalizado na forma de portlandita, fase mecanicamente menos resistente.

Outro fato que contrariou as expectativas foi a elevação do índice de atividade pozolânica com cimento, aos 28 dias de cura, para todas as amostras calcinadas à $850^{\circ} \mathrm{C}$. Era esperado que os índices seguissem a mesma tendência obtida em ensaios 
com a cal, porém isso não ocorreu. Atribuiu-se este fato à cinética de reação entre as fases presentes e a cal, nos períodos de 7 e 28 dias. Como todas as amostras continham caulinita em suas composições, é possível que a reação pozolânica tenha ocorrido primeiramente entre a cal e a metacaulinita e findado aos 7 dias.

A calcinação em temperaturas inferiores à $700^{\circ} \mathrm{C}$ foi insuficiente para que a esmectita, a illita e os interestratificados de illita/esmectita sofressem destruição total do retículo cristalino e adquirissem maior reatividade química.

A calcinação em temperaturas mais elevadas teria permitido que os argilominerais atingissem estruturas metaestáveis e portanto, mais reativas, fato observado por Zampieri (1989, 1993) e Metha (1994). Assim, inferiu-se que a esmectita e a illita calcinadas à $850^{\circ} \mathrm{C}$, quando submetidas a um meio quimicamente agressivo de caráter fortemente alcalino, como uma mistura de cimento e água, possibilitariam a ocorrência de reação pozolânica, porém numa cinética de reação mais lenta do que a metacaulinita, e por isso teria sido constatada somente aos 28 dias de cura.

Por último buscou-se verificar a adequação dos resultados obtidos frente às especificações físicas e químicas estabelecidos pela NBR 12653/92 (ABNT, 1992a) (Tabela 7.16). Os resultados mostraram que os lamitos na forma natural não são pozolanas, contrapondo aos lamitos calcinados que se mostraram mais adequados como pozolanas. O desvio máximo relativo entre os valores obtidos e os especificados não ultrapassou $5 \%$, para as amostras calcinadas nas temperaturas de 550,600 e $700^{\circ} \mathrm{C}$. 
Tabela 7.16: Enquadramento dos resultados obtidos nas especificações NBR 12653/92 (ABNT, 1992a)

\begin{tabular}{|c|c|c|c|c|c|c|c|c|c|c|c|}
\hline \multirow{3}{*}{\multicolumn{2}{|c|}{ Amostra }} & \multicolumn{5}{|c|}{ Especificaçōes Químicas } & \multicolumn{3}{|c|}{$\begin{array}{l}\text { Especificações Físicas } \\
\text { Indice de atividade pozolânica }\end{array}$} & \multirow{3}{*}{\begin{tabular}{|c|}
$\begin{array}{c}\text { água requerida } \\
\text { (\% máx })\end{array}$ \\
115
\end{tabular}} & \multirow{3}{*}{ Conformidade } \\
\hline & & \multirow{2}{*}{$\begin{array}{c}\begin{array}{c}\mathrm{SiO}_{2}+\mathrm{Al}_{2} \mathrm{O}_{3}+ \\
\mathrm{Fe}_{2} \mathrm{O}_{3} \\
(\% \mathrm{~min} .)\end{array} \\
70\end{array}$} & \multirow{2}{*}{\begin{tabular}{|c|}
$\begin{array}{c}\mathrm{SO}_{3} \\
(\% \text { máx. })\end{array}$ \\
4 \\
\end{tabular}} & \multirow{2}{*}{$\begin{array}{c}\begin{array}{c}\text { Teor de } \\
\text { umidade } \\
\text { (máx.) }\end{array} \\
3\end{array}$} & \multirow{2}{*}{\begin{tabular}{|c|}
$\begin{array}{c}\text { Perda ao fogo } \\
(\% \text { máx. })\end{array}$ \\
10
\end{tabular}} & \multirow{2}{*}{$\begin{array}{c}\text { Álcalis } \\
\text { disponiveis em } \\
\begin{array}{c}\mathrm{Na}_{2} \mathrm{O} \\
(\% \text { máx. })\end{array} \\
1,5\end{array}$} & \multirow{2}{*}{$\begin{array}{c}\begin{array}{c}\text { Material retido na } \\
\text { peneira } 45 \mu \mathrm{m} \\
(\% \text { máx. }\end{array} \\
34\end{array}$} & \multirow{2}{*}{$\begin{array}{c}\begin{array}{c}\text { com cimento } \\
\text { aos } 28 \text { dias } \\
(\% \text { min. })\end{array} \\
75\end{array}$} & \multirow{2}{*}{$\begin{array}{c}\text { com o cal } \\
\begin{array}{c}\text { aos } 7 \text { dias } \\
(\mathrm{MPa})\end{array} \\
6\end{array}$} & & \\
\hline & & & & & & & & & & & \\
\hline \multirow{5}{*}{$\mathrm{C} 6 \mathrm{~V}$} & natural & 85,98 & \multirow{5}{*}{ nd. } & \multirow{5}{*}{ nd. } & 10,29 & \multirow{5}{*}{ nd. } & 12,9 & nd. & 0,0 & nd. & 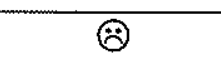 \\
\hline & 550 & & & & & & nd. & nd. & nd. & nd. & \\
\hline & 600 & & & & & & 18,9 & 77,9 & 10,1 & 112,3 & (:) \\
\hline & 700 & & & & & & nd. & nd. & nd. & nd. & \\
\hline & 850 & $95,84^{*}$ & & & & & 19,9 & 87,1 & 7,8 & 109,5 & (9) \\
\hline \multirow{5}{*}{ C5A } & natural & 85,28 & \multirow{5}{*}{ nd. } & \multirow{5}{*}{ nd. } & 9,81 & \multirow{5}{*}{ nd. } & 18,4 & nd. & 6 & nd. & $\theta$ \\
\hline & 550 & & & & & & 19,4 & nd. & 7,2 & nd. & () \\
\hline & 600 & & & & & & 19,1 & nd. & 9,1 & nd. & ()) \\
\hline & 700 & & & & & & 19,3 & nd. & 10,6 & nd. & () \\
\hline & 850 & $94,90^{*}$ & & & & & nd. & nd. & nd. & nd. & \\
\hline \multirow{5}{*}{ C11 } & natural & 85,16 & \multirow{5}{*}{ nd. } & \multirow{5}{*}{ nd. } & 10,25 & \multirow{5}{*}{ nd. } & 19,0 & 867 & 00 & 1410 & (2) \\
\hline & 550 & & & & & & 19,8 & 74,8 & 8,1 & $16 \%$ & $\theta$ \\
\hline & 600 & & & & & & 16,8 & 741 & 9,6 & 111,7 & $\Theta$ \\
\hline & 700 & & & & & & 17,8 & nd. & 10,0 & nd. & \\
\hline & 850 & $95,24^{*}$ & & & & & 18,6 & 86,8 & 7,6 & 109,5 & ()) \\
\hline \multirow{5}{*}{ C19 } & natural & 85,88 & \multirow{5}{*}{ nd. } & \multirow{5}{*}{ nd. } & 10,00 & \multirow{5}{*}{ nd. } & nd. & nd. & nd. & nd. & \\
\hline & 550 & & & & & & nd. & nd. & nd. & nd. & \\
\hline & 600 & & & & & & 19,5 & 71,6 & 8,5 & 112,3 & $\oplus$ \\
\hline & 700 & & & & & & nd. & nd. & nd. & nd. & \\
\hline & 850 & $95,73^{*}$ & & & & & 19,7 & 83,8 & 7,0 & 110,1 & (). \\
\hline
\end{tabular}

calculado a partir da análise química considerando-se perda ao fogo total na temperatura; nd. não determinado

(:) - parâmetros determinados em total conformidade; $)-$ - parâmetros determinados em parcial conformidade; $: 2$ - fora de especificação. 


\section{CAPÍTULO VIII - CONCLUSÕES}

Os trabalhos desenvolvidos em área de ocorrência da Formação Resende - Bacia de Taubaté, permitiram caracterizar o estéril da mineração de areia com o objetivo de apontar alternativas de valoração aos materiais atualmente desprezado, através de ensaios de aplicação específicos dos segmentos cerâmicos e de cimento. Esta Formação é constituída por pacotes tabulares métricos de lamitos, lamitos arenosos e siltitos arenosos, intercalados aos niveis arenosos métricos dos quais se extrai a areia.

A destinação industrial dos estéreis resultaria numa série de benefícios econômicos e ambientais. O impacto imediato seria observado na redução dos custos de produção da areia, e também no prolongamento da vida útil da jazida, devido à menor ocupação de áreas por bota-foras, e, como contribuição ao meio ambiente, a exposição de materiais às intempéries, evitando assim assoreamento de cursos d'água e a poluição visual.

Através da caracterização tecnológica foram obtidas as composições química e mineralógica, assim como a distribuição granulométrica dos diversos tipos de lamitos/siltitos mobilizados na lavra de areia. A assembléia mineralógica dos lamitos mostrou-se homogênea, composta por cerca de $50 \%$ de esmectita, $30 \%$ de caulinita e $15 \%$ de illita, e $5 \%$ de acessórios (quartzo, feldspato e outros). Os lamitos arenosos e os siltitos arenosos apresentaram composições mais heterogêneas, com variações químicas e mineralógicas, principalmente relativas às proporções de esmectita, caulinita e quartzo.

Ensaios específicos de aplicabilidade desses materiais no setor cerâmico, visando o segmento de cerâmica estrutural, indicaram a potencialidade de uso dos lamitos e lamitos arenosos como matéria-prima para a confecção de tijolos de alvenaria, blocos furados e telhas. Somente uma amostra de siltito arenoso teria sua aplicação retrita a tijolos de alvenaria, devido à baixa resistência mecânica encontrada $(4,10 \mathrm{MPa})$. Embora os índices de absorção de água e módulo de ruptura tenham sido satisfatórios, os materiais estudados apresentaram elevada plasticidade, o que refletiria em elevada retração de secagem e possivelmente geração de trincas.

Os resultados cerâmicos, absorção de água e módulo de ruptura à flexão, obtidos para corpos-de-prova de lamitos e lamitos arenosos, prensados e queimados à $950^{\circ} \mathrm{C}$, revelaram que algumas propriedades obtidas decorreram das características naturais parcialmente preservadas, como ocorreu com a absorção de água, mais elevada para os lamitos, devido à facilidade de adsorção da esmectita. 
Na temperatura de $1100^{\circ} \mathrm{C}$, os índices físicos obtidos foram mais elevados do que na de $950{ }^{\circ} \mathrm{C}$, com resultados mais dispersos, porém também correlacionados com as características naturais das amostras. Os lamitos na queima a $1100{ }^{\circ} \mathrm{C}$ apresentaram maiores valores de resistência mecânica e menores absorções de água que os siltitos arenosos, contrariamente ao ocorrido à $950^{\circ} \mathrm{C}$, em decorrência à nucleação de mulita e geração de fase vítrea.

Quanto à potencialidade de uso no segmento de cerâmica de revestimento, parte dos lamitos poderiam ser utilizados na fabricação de placas cerâmicas (piso e revestimento) com características de grés. As resistências mecânicas obtidas para os demais materiais foram pouco inferiores ao limite mínimo requerido na confecção de produtos semi-grés, semi-poroso e poroso. Assim, esses materiais poderiam ser utilizados na fabricação de revestimentos cerâmicos em adição às massas cerâmicas convencionais (argilas comuns, caulim, fundentes, quartzo, etc.), na qual seriam valorizadas a plasticidade elevada do material natural e a baixa absorção de água após a queima.

Foi investigada, ainda, a aplicabilidade desses materiais no setor de cimento, visando o uso como pozolana. Os estudos contemplaram aplicação no estado natural e após ativação por calcinação, tendo sido conduzidos ensaios com cal e com cimento.

Dos ensaios de atividade pozolânica com cal pôde-se concluir que as amostras não apresentaram nenhuma potencialidade como pozolanas naturais. Por outro lado, os indices de atividade pozolânica com cal para lamito e lamito arenoso, após a calcinação a $550,600,700$ e $850^{\circ} \mathrm{C}$, superaram em 17 e $76 \%$ o limite mínimo fixado pela norma brasileira $(6 \mathrm{MPa})$. Para esse ensaio, a temperatura ótima de calcinação foi encontrada em $700^{\circ} \mathrm{C}$, com as melhores resistências mecânicas.

Em relação à determinação do índice de atividade pozolânica com cimento, os resultados obtidos foram cerca de $5 \%$ abaixo do valor mínimo estabelecido pela norma brasileira (75\%), para os lamitos calcinados à 550,600 e $700^{\circ} \mathrm{C}$. Os maiores índices foram obtidos para lamitos calcinados à $850^{\circ} \mathrm{C}$, sendo essa, então, a temperatura ótima de ativação. Embora os melhores índices estejam relacionados à maior temperatura de calcinação, infere-se que resultados igualmente satisfatórios poderiam ser encontrados para as amostras calcinadas em temperaturas menores, entre 600 e $850^{\circ} \mathrm{C}$, desde que o volume de cimento substituído por pozolana fosse menor que o recomendado pela norma $e$ utilizado nos ensaios $(35 \%)$.

Verificou-se que dos três litotipos estudados, os lamitos foram os que apresentaram menor variabilidade em suas características naturais, fator que refletiu nos resultados de 
ensaios de aplicação. Esse fato representa para a mineração, a perspectiva da execução de lavra seletiva a partir da identificação dos tipos tecnológicos, o que para a indústria asseguraria o fornecimento de matérias-primas qualitativamente homogêneas.

Analisando-se sob o ponto de vista cerâmico, a distância de pelo menos $130 \mathrm{~km}$, entre Mogi das Cruzes e as possiveis consumidoras (indústrias de revestimento cerâmico de Mogi Guaçu, Porto Ferreira, etc.), tornaria o custo da matéria-prima inacessivel, comparado com as argilas comuns encontradas próximas às indústrias. Entretanto, se esses materiais forem utilizados em substituição a argilas plásticas (bentonitas, por exemplo), geralmente mais caras, a comercialização se tornaria mais atrativa. Por outro lado, a instalação de indústrias de cerâmica estrutural na região do Bairro do Taboão favoreceria a RMSP, pela potencialidade de abastecimento de blocos, tijolos, telhas, etc., e também às minerações, pela elevada demanda de matérias-primas.

Para as indústrias de cimento, a matéria-prima pozolânica pode ser no máximo transportada por $80 \mathrm{~km}$ (praticada em 2002 segundo informação verbal de consultores do setor), acima dessa distância o custo do transporte inviabilizaria o seu uso. No município de Mogi das Cruzes, há uma única unidade de moagem de clínquer da Cimento Tupi, que não fabrica o Cimento Portland Pozolânico. Assim, os lamitos da Formação Resende, apesar de se tornarem pozolanas adequadas após calcinação, se consistiriam em matérias-primas estratégicas para uma demanda futura.

Os sedimentares terciários da Formação Resende são amplamente distribuídos pela Bacia de Taubaté. Esse é um fato importante quando se trata de fornecimento de matérias-primas, por indicar existência de recursos minerais suficientes para abastecimento de um processo industrial.

Quanto o aspecto qualitativo desses materiais deve-se salientar a importância e a necessidade, para cada local, de caracterização das matérias-primas potenciais, definição da geometria dos pacotes lamíticos através de pesquisa geológica sistemática e determinação dos tipos litológicos presentes, haja visto que o presente trabalho restringiu-se um único depósito mineral. 


\section{REFERÊNCIAS BIBLIOGRÁFICAS}

AMADOR, E. S. (1975) Estratigrafia e sedimentação da Bacia de Resende, RJ. An. Acad. bras. Ci., 47: 181-225.

AMBROISE, J.; MARTIN-CALLE, S.; PÉRA, J. (1992) Pozzolanic behavior of thermally activated kaolin. In: FLY ASH, SILICA FUME, SLAG, AND NATURAL POZZOLANS IN CONCRETE. Proceedings Fourth International Conference, Istanbul, Turkey. Vol. I. Sp-132. ACl/CANMET.p731-761.

ASSOCIAÇÃO BRASILEIRA DE CERÂMICA - ABC. (2000) A indústria cerâmica brasileira. [www document] URL http:// www.abceram.org.br. Acesso em $15 / 10 / 2000$.

ASSOCIAÇÃO BRASILEIRA DE CERÂMICA - ABC. (2002) Anuário Brasileiro de Cerâmica 2002. São Paulo, ABC. 194p.

ASSOCIAÇÃO BRASILEIRA DE CIMENTO PORTLAND - ABCP \& INSTITUTO BRASILEIRO DO CONCRETO - IBRACON. (1993) Cimento Porltand: Atuais especificações e suas aplicações. Revista IBRACON, $n^{\circ} 43:$ 59-60.

ASSOCIAÇÃO BRASILEIRA DE CIMENTO PORTLAND - ABCP. (2001) Cimento Portland - Atuais especificações e suas aplicações. ABCP, 4p.

ASSOCIAÇÃO BRASILEIRA DE NORMAS TÉCNICAS - ABNT. (1983) Blocos cerâmicos para alvenaria. Especificação - NBR 7171. Rio de Janeiro. ABNT, $11 \mathrm{p}$.

ASSOCIAÇÃO BRASILEIRA DE NORMAS TÉCNICAS - ABNT. (1984a) Solo Determinação do limite de liquidez - NBR6459. Rio de Janeiro, ABNT.

ASSOCIAÇÃO BRASILEIRA DE NORMAS TÉCNICAS - ABNT. (1984b) Solo Determinação do limite de plasticidade - NBR7180. Rio de Janeiro, ABNT.

ASSOCIAÇÃO BRASILEIRA DE NORMAS TÉCNICAS - ABNT. (1986) Amostras de solo - Preparação para ensaios de compactação e ensaios de caracterização NBR 6457. Rio de Janeiro, ABNT.

ASSOCIAÇÃO BRASILEIRA DE NORMAS TÉCNICAS - ABNT. (1990) Aglomerantes de origem mineral - NBR 11172. Rio de Janeiro, ABNT. 5p. 
ASSOCIAÇÃO BRASILEIRA DE NORMAS TÉCNICAS - ABNT. (1991a) Cimento Portland Comum - NBR5732. Rio de Janeiro, ABNT. 5p.

ASSOCIAÇÃO BRASILEIRA DE NORMAS TÉCNICAS - ABNT. (1991b) Cimento Portland Composto - NBR11578. Rio de Janeiro, ABNT. 5p.

ASSOCIAÇÃO BRASILEIRA DE NORMAS TÉCNICAS - ABNT. (1991c) Cimento Portland Pozolânico - NBR5736/EB-758. Rio de Janeiro, ABNT. 6p.

ASSOCIAÇÃO BRASILEIRA DE NORMAS TÉCNICAS - ABNT. (1992a) Materiais pozolânicos - NBR12653. Rio de Janeiro, ABNT. 3p.

ASSOCIAÇÃO BRASILEIRA DE NORMAS TÉCNICAS - ABNT. (1992b) Materiais pozolânicos - Determinação da atividade pozolânica - Indice de atividade pozolânica com cal - NBR5751. Rio de Janeiro, ABNT. 3p.

ASSOCIAÇÃO BRASILEIRA DE NORMAS TÉCNICAS - ABNT. (1992C) Materiais pozolânicos - Determinação da atividade pozolânica com cimento Portland Indice de atividade pozolânica com cimento - NBR5752. Rio de Janeiro, ABNT. $3 p$.

ASSOCIAÇÃO BRASILEIRA DE NORMAS TÉCNICAS - ABNT. (1993) Cimento Portland e outros materiais em pó - Determinação do indice de finura por meio de peneirador aerodinâmico - NBR 12826. Rio de Janeiro. ABNT.

ASSOCIAÇÃO BRASILEIRA DE NORMAS TÉCNICAS - ABNT. (1996) Cimento Portland - Determinação da resistência à compressão - NBR7215. Rio de Janeiro, ABNT. 8p.

ASSOCIAÇÃO BRASILEIRA DE NORMAS TÉCNICAS - ABNT. (1997a) Placas cerâmicas para revestimento: Classificação - NBR13817. Rio de Janeiro, ABNT, $3 p$.

ASSOCIAÇÃO BRASILEIRA DE NORMAS TÉCNICAS - ABNT. (1997b) Placas cerâmicas para revestimento: Especificação e métodos de ensaio - NBR13818. Rio de Janeiro, ABNT, 77p.

ASSOCIAÇÃO BRASILEIRA DE NORMAS TÉCNICAS - ABNT. (1998) Cimento Portland - Determinação da finura pelo método de permeabilidade ao ar (Método Blaine) - NBR NM76. Rio de Janeiro. ABNT. 
ASSOCIAÇÃO BRASILEIRA DE NORMAS TÉCNICAS - ABNT. (2001) Cimento Portland - Determinação da massa específica - NBR NM23. Rio de Janeiro. ABNT.

ASSOCIAÇÃO NACIONAL DAS ENTIDADES DE PRODUTORES DE AGREGADOS PARA CONSTRUÇÃO CIVIL - ANEPAC. (2000) Vale do Paraíba: maior região produtora de areia do país. Revista Areia \& Brita $n^{\circ} 10: 5-19$.

ASSOCIAÇÃO NACIONAL DOS FABRICANTES DE CERÂMICA PARA REVESTIMENTO. (1999) Panorama da Indústria Cerâmica Brasileira. ANFACER.

ASSOCIAÇÃO NACIONAL DOS FABRICANTES DE CERÂMICA PARA REVESTIMENTO - ANFACER. (2002) Produção e capacidade instalada. ANFACER [www document] URL http://www.anfacer.org.br. Acesso em 05/05/2002.

ASSOCIAÇÃO TÉCNICA BRASILEIRA DAS INDÚSTRIAS AUTOMÁTICAS DE VIDRO. (2002) Desempenho global do setor vidreiro - 2002 para 2001. ABIVIDRO [www document] URL http://www.abividro.org.br. Acesso em $20 / 05 / 2002$.

BAILEY, S. W. (ed) . (1984) Micas. In: Reviews in mineralogy. Mineralogical Society of America, v. 13, 584 p. ill.

BAIN, J.A. (1986) Composition and properties of clays used in various fields of ceramics. In: Part 1. Fields reports. Lecture held on the occasion of the joint meeting of the DTTG (German Clay and Clay Minerals Group) and the Mid Regional Group of the German Ceramic Society (raw materials), Haiger Dillkreis, F.R.G. (ed.), p.536-538.

BARELLI, N.; SANTILLI, C.V.; CRESPI, M.S. (1994) Estudo de argilas do Vale do Paraíba, com ênfase no tamanho e distribuição de poros. Cerâmica, 40(264): 5-7.

BAUERMEISTER, K.H. (1996) Distribuição e disponibilidade das áreas de extração de areia para a construção civil, visando o abastecimento da Região Metropolitana de São Paulo. 108p: il. Dissertação de Mestrado. Instituto de Geociências -USP.

BOCCHILI, C. (2001) Consulta técnica. In: Contrução Mercado: Custos, suprimentos, planejamento e controle de obras. Ed. PINI., n². Ano 54. 
BRANDT NETO, M.; RICCOMINI, C.; COIMBRA, A.M.; MATOS, S. L.F. (1991) Argilominerais da Bacia de Taubaté. Bol. IG-USP, Publicação Especial $n^{\circ} 9$. Jornadas Científicas. São Paulo. p:111-115.

BUSTAMANTE, G.M. \& BRESSIANI, J.C. (2000) A indústria cerâmica Brasileira. Cerâmica Industrial, 5(3): 31-36.

BUSTAMANTE, G.M. (1998) Situação da indústria cerâmica brasileira (transparências de palestra apresentada em maio de 1998). 19p.

CAPUTO, H. P. (1975) Mecânica dos solos e suas aplicações. $5^{\circ}$ ed. Livros Técnicos e Científicos, Rio De Janeiro.

CENTRO CERÂMICO DO BRASIL - CCB. (1998) Qualidade e inovação tecnológica. CCB. 34p.

CENTRO CERÂMICO DO BRASIL - CCB (1999) Projeto Plataforma para indústria brasileira de revestimentos cerâmicos, São Paulo: CCB/PADCT (inédito).

CIA DE CIMENTO ITAMBÉ. (2001) [www document] URL http://www.cimentoitambé.com.br. Acesso em 20/05/2001.

COIMBRA, A. M.; RICCOMINI, C.; MELO, M.S. (1993) A Formação Itaquaquecetuba: evidências de tectonismo no quaternário paulista. In: SIMPOSIO REGIONAL DE GEOLOGIA, 4, São Paulo. Atas. São Paulo, SBG, p. 253-266.

CUCHIERATO, G. (2000) Caracterização dos resíduos de mineração de agregados da Região Metropolitana de São Paulo visando seu aproveitamento econômico. Dissertação de Mestrado. IGc-USP.

DEPARTAMENTO NACIONAL DE PRODUÇÃO MINERAL - DNPM. (1967) Código de Mineração Brasileiro (DECRETO-LEI N. ${ }^{\circ} 227$, de 27 fevereiro de 1967).

DEPARTAMENTO NACIONAL DE PRODUÇÃO MINERAL - DNPM. (2000) Portaria $n^{\circ} 40$, de 10 de fevereiro de 2000.

DEPARTAMENTO NACIONAL DE PRODUÇÃO MINERAL - DNPM (2001) Sumário Mineral. DNPM, 122p.

DEPARTAMENTO NACIONAL DE PRODUÇÃO MINERAL - DNPM. (2002) Cadastro Mineiro: Substância agrupadora areia, Município de Mogi das Cruzes e 
Guararema, Estado de São Paulo. DNPM/SICOM, [www document] URL http://www.dnpm.gov.br/sicom. Acesso em 29/04/2002.

DONDI, M. (1999) Clay materials for ceramics tiles from the Sassuolo District (Northern Apennines, Italy). Geology, composition and technological properties. Appied Clay Science, 15: 337-366.

FLORÊNCIO, R. V. DE SOUSA. (1999) As argilas do Subgrupo Itararé: potencialidades como matérias primas cerâmicas e como inertizadores de resíduos industriais. Tese de Doutoramento. Instituto de Geociências-USP. 179p + anexos.

FOLK, R.L. (1974) Petrology of sedimentary rocks. 2ed. Austin, Tex., Hemphill's. 182p.

GAMBULI, P. (2001) Tendência mundiais da produção de revestimentos cerâmicos. Cerâmica Industrial, 6(6): 7-10.

GARRONI, R. (1958) O papel do controle da qualidade na indústria cerâmica. Cerâmica, 4(14): 40.

GASPAR JR., L.A. (1998) Estudo mineralógico, químico e textural das rochas sedimentares da Formação Corumbatai (Jazida Peruchi) e suas implicações com a matéria-prima para cerâmica vermelha. Dissertação de Mestrado - UNESP. Rio Claro. 146p + anexos.

GIPPINI, E. (1969) Contribution à l'étude des propriétés de moulage des argiles et des mélanges optimaux de matières premières. L'Industrie Céramique, n619. p. 423-435.

GRIM, R. E. (1968) Clay mineralogy. New York, McGraw-Hill. $2^{\circ}$ ed. 596 p.

GROSS, F.J. (1957) Problemas de pesquisa na indústria nacional de produtos estruturais de argila. Cerâmica, 3(10): 63-71.

GUGGENHEIM, S. \& GROOS, A.F.K. van. (2001) Baseline studies of the Clay Minerals Society Cource Clays: The thermal analysis. Clay and Clay Minerals. Journal of the Clay Minerals Society, 49(5): 433-443.

HASUI, Y.; CARNEIRO, C.D.R.; COIMBRA, A. M. (1975) The Ribeira Folded Belt. Rev. Bras. Geoc.; 5: 257-266.

HASUI, Y.; DANTAS, A.S.; CARNEIRO, C.D.R.; BISTRICH, C.A. (1981) O Embasamento Pré-Cambriano e o Eopaleozóico em São Paulo. In: Mapa Geológico do Estado de São Paulo (escala 1:500.000). Pró-minério/Promocet, vol. 1, p 13-45. 
HE, C.; MAKOVICKY, E.; OSB/ECK. (1994) Thermal stability and pozzolanic activity of calcined kaolin. Applied Clay Science, 9: 165-187.

HE, C.; MAKOVICKY, E.; B, OSBAECK. (1995a) Thermal stability and pozzolanic activity of calcined illite. Applied Clay Science, 9: 337-354.

HE, C.; MAKOVICKY, E.; B, OSBAECK. (1996) Thermal treatment and pozzolanic activity of Na- and Ca-montmorillonite. Applied Clay Science, 10: 351-368.

HE, C.; MAKOVICKY, E.; OSBAECK. (2000) Thermal stabitity and pozzolanic activity of raw and calcined mixed-layer mica/smectite. Applied Clay Science 17: 141-164.

HE, C.; OSBAECK, B.; MAKOVICKY, E. (1995b) Pozzolanic reactions of six principal clay minerals: activation, reactivity assessments and technological effects. Cement and Concrete Research, 25(8): 1691-1702.

KIHARA, Y. ; ESPER, M. W. (1986) Perfil dos Cimentos Portland Pozolânicos Brasileiros. 2.ed. rev. atual. São Paulo, $A B C P, 36 p$.

LABORATÓRIO DE CARACTERIZAÇÃO TECNOLÓGICA - LCT. (2000) Caracterização Tecnológica de matérias-primas minerais. Curso de Extensão, março de 2000.

LIEBIG, E.; ALTHAUS, E. (1997) Kaolinit und montmorillonit als puzzolanische komponenten in kalkmörteln - unbehandelt und nach thermischer aktivierung. ZKG International, 50(5): 282-290.

LOLLI, L. NASSETTI, G.; MARINO, L.F.B. (2000). A preparação a seco de massas cerâmicas. Cerâmica Industrial, 5(2): 23-27.

MALHOTRA. V.M. MEHTA, P.K. (1996) Pozzolanic and Cementitious Materials. In Advances in Concrete Technology, Gordon and Breach Publishers. Ottawa, Ontario, Canada. Vol. 1, 191p.

MANCINI, F. (1995) Estratigrafica e aspectos da tectônica deformadora da Formação Pindamonhangaba, Bacia de Taubaté, SP. Dissertação de Mestrado - IGc-USP. 107p.

MASSAZZA, F. (2001) Pozzolana and pozzolanic cements. In: LEA'S Chemistry of Cement and Concrete. Forth Edition. Peter C. Hewlett (ed.). Editora Butterworth Heinemann, p.471-636. 
MEHTA, P.K. (1994) Capítulo 6. Aglomerantes hidráulicos. In: Concreto: estrutura, propriedades e materiais. Tradução e adaptação de CINCOTTO, M. A.; HELENE, P., Editora PINI Ltda. p.187-238.

MEHTA, P.K. (1998) Role of pozzolanic \& cementitious by-productos in sustainable development of the Concrete Industry in Sixth CANMET/ACl/JCl Conference: Fly Ash, Silica Fume, Slag \& Natural Pozzolans in Concrete, 1998. In: Environmental Building News - The leading Newsletter on Enviromentally Responsible Design and Construction. [www document] URL http://www.buildinggreeen.com. Acesso em 02/12/2000.

MIELENZ , R.C.; GREENE, K.T. \& SCHIELTZ, N.C. (1951) Natural pozzolan for concrete. Economic Geology, 46: 311-328.

MONTANHEIRO, T. J. (1999) Prospecção e caracterização de pozolanas na Bacia do Paraná, Estado de São Paulo. Tese de Doutoramento. IGC-USP. 226p.

MOORE, D.M.; REYNOLDS, R.C. (1997) X-ray diffraction and the identification and analysis of clay minerals. Oxford : Oxford University Press, New York : 2. ed., $378 p$.

MORGADO, A. F. (1993) Caracterização cerâmica de algumas argilas e caulins de Santa Catarina. Dissertação de Mestrado. Escola Politécnica USP - Depto de Engenharia Química. 75p.

MOTTA, J. F.M. (1991) Avaliação do potencial geológico para argilas plásticas para cerâmica branca no Estado de São Paulo. Dissertação de Mestrado . UNESPRio Claro. $176 p$ : il.

MOTTA, J.F.; CABRAL JR, TANNO, L.C. (1998) Panorama das matérias-primas utilizadas na indústria de revestimentos cerâmicos: Desafios ao setor produtivo. Cerâmica Industrial, 3(4m6): 30-37.

MOTTA, J.F.; ZANARDO, A.; CABRAL JR, M. (2001) As matérias-primas cerâmicas. Parte I: O perfil das principais indústrias cerâmicas e seus produtos. Cerâmica Industrial, 6(2): 30-39.

MURAT, M. (1983) Hydratation reaction and hardening of calcined clays and related minerals. II. Influence of mineralogical properties of the raw-kaolinite on the reactivity of metakaolinite. In: Cement and Concrete Research. Pergamon Press, Ldt. USA. Vol. 13. p.511-518. 
MURRAY, H.H. (1991) Overview - Clay mineral applications. Applied Clay Science, 5: 379-395.

MURRAY, H.H. (2000) Traditional and new application for kaolin, smectite, and palygorskite: a general overview. Applied Clay Science, 17: 207-221.

NASSETTI, G.; PALMONARI, C. (1997) Moagem fina à seco vs. moagem à úmido e atomização na preparação de massas de base vermelha para monoqueima rápida de pisos e vidrados. Cerâmica Industrial, 2(5/6): 11-15.

PAIVA NETO, J.E. de; NASCIMENTO, A.C. (1956) Argilas bentoníticas no Terciário do Vale do Paraiba. Boletim da Sociedade Brasileira de Geologia, 5(2): 5-16.

PERA, J. (2001). Metakaolin and calcined clays. In: Cement and Concrete Composities, 23:iii.

PRACIDELLI, S. ; MELCHIADES, F.G. (1997) Importância da composição granulométrica de massas para a cerâmica vermelha. Cerâmica Industrial, 2(01/02): 32-35.

PREFEITURA MUNICIPAL DE MOGI DAS CRUZES. (2002) Mogi e o Parque Industrial. [www document] URL http://www.mogidascruzes.sp.gov.br. Acesso em 10/12/2001.

RICCOMINI, C. \& COIMBRA, A. M. (1992) Geologia da bacia sedimentar. In: NEGRO JR., A.; FERREIRA, A.A.; ALONSO, U.R.; LUZ, P.A. (eds.) Solos da Cidade de São Paulo. ABMS/ABEF, São Paulo, p. 37-94.

RICCOMINI, C. ;COIMBRA, A.M.; SANT'ANNA, L.G.; BRANDT NETO, M.; VALARELLI, J.V. (1996) Argilominerais do paleolago Tremembé e sistemas deposicionais relacionados (Paleógeno, Rift Continental do Sudeste do Brasil). Revista Brasileira de Geociências, 26(3): 167-180.

RICCOMINI, C. (1989) Rift continental do sudeste do Brasil. Tese de Doutoramento. IG-USP. 256p : il +. mapa

RICCOMINI, C.; COIMBRA, A.M.; BRANDT NETO, M.; SANT'ANNA, L.G. (1994) Geologia e aspectos tecnológicos das argilas esmectíticas do Estado de São Paulo. in Workshop: Recursos Minerais Não-Metálicos para o Estado de São Paulo - Resumos Expandidos. SBG. p.43-57. 
RICCOMINI, C.; COIMBRA, A.M.; SUGUIO, K.; MIHÁLY, P.; MATURANA, E.C. (1991) Nova unidade litoestratigráfica cenozóica da Bacia de Taubaté, SP: Formação Pindamonhangaba. Boletim IC-USP. Publicação Especial $n^{\circ}$ 9. Jornadas Científicas. São Paulo. p:141-149.

RICCOMINI, C.; SUGUIO, K.; ALVARENGA, H.M.F.; FITTIPALDI, F. (1991) Estratigrafia e ambientes de sedimentação da porção central da Bacia de Taubaté, SP. In: XII CONGRESSO BRASILEIRO DE PALEONTOLOGIA. Roteiro de Excursões: Bacia do Paraná I, Bacia do Paraná II e Bacia de Taubaté. p:1-29.

RODRIGUES, S. \& SOUZA SANTOS, P. (1978) O "Sistema Argila-Água". Cerâmica, 24(101): 253-278.

RODRIGUEZ, S.K. (1998) Geologia urbana da Região Metropolitana de São Paulo. Tese de Doutoramento - IG-USP. 171p + anexos.

SABIR, B.B.; WILD, S.; BAI, J. (2001) Metakaolin and calniced clays as pozzolans for concrete: a review. In: Cement and Concrete Composities 23: 441-454.

SALLES, F. \& AZEVEDO, V. (1965) Os primórdios da indústria cerâmica em São Paulo. Cerâmica, 11(44): 25-33.

SANT'ANNA, L. (1999) Geologia, mineralogia e gênese das esmectitas dos depósitos paleogênicos do rift continental do Sudeste do Brasil . Tese de Doutoramento. 293p. : il. + anexos.

SHEPPARD, F.P. (1954) Revised nomenclature for depositional coastal features. Amer. Ass. Pet. Geol. Bull., Tulsa, 36(10): 1902-1912.

SINDICATO NACIONAL DAS INDÚSTRIAS DE CIMENTO - SNIC. (1998) 45 Anos: 1953-1997. Rio de Janeiro. SNIC, 62p.

SINDICATO NACIONAL DAS INDÚSTRIAS DE CIMENTO - SNIC. (1999) Anuário de 1998. Rio de Janeiro. SNIC, 58p.

SINDICATO NACIONAL DAS INDÚSTRIAS DE CIMENTO - SNIC. (2000) Anuário de 1999. Rio de Janeiro. SNIC, 58p.

SINDICATO NACIONAL DAS INDÚSTRIAS DE CIMENTO - SNIC. (2001) Anuário de 2000. Rio de Janeiro. SNIC, 58p. 
SINDICATO NACIONAL DAS INDÚSTRIAS DE CIMENTO- SNIC. (2002) Anuário de 2001. [www document] URL http://www.sindicatodocimento.com.br. Acesso em 20/05/2002.

SMYKATZ-KLOSS, W. (1974) Differential termal analysis - Application and results in mineralogy. Mineral and rocks, 11: 185p.

SOUZA SANTOS, P. \& SANTINI, P. (1965) Ocorrências de argilas montmorilloníticas no Brasil. Cerâmica, 11(44): 36-65.

SOUZA SANTOS, P. (1963) Análise térmica diferencial de argilas descorantes. Bol. Téc. PETROBRÁS, 6(2): 117-174.

SOUZA SANTOS, P. (1989) Ciência e Tecnologia das Argilas. Vol. 1. $2^{\circ}$ ed. São Paulo. $408 p$.

SRODÓN, J.; DRITS, V.A.; MCCARTHY, D. K.; HSIEK, J.C.C.; EBERL, D.D. (2001). Quantitative $x$-ray difraction analysis of clay bearing rocks from random preparations. Clay and clay Minerals, 49(6). 514-528.

STRAZZERA, B. Dondi, M.; Marsigli, M. (1997) Composition and ceramic properties of Tertiary clays from southern Sadinian (Italy). Applied Clay Science, 12: 247-266.

SUGUIO, K. (1973) Introdução à sedimentologia. Editora E. Blücher - São Paulo. 317p.

TALVANI, E. L.; VOLZONE, C. (1999) Adsorption of sulphuric acid on smectite from acidic solutions. Cerâmica, 45 (295): 133-136.

TANNO, L.C. \& MOTTA, J.F.M. (2000) Panorama setorial - Minerais industriais. Cerâmica Industrial, 5(3): 37-40.

TAYRA, F. (1998) Análise Setorial: A indústria do Cimento. Panorama Setorial, Gazeta Mercantil. Vol. 1, 202p.

THOREZ, J. (1976) Practical identification of clay minerals: a handbook for teachers and students in clay mineralogy. Dison: Lelotte, 90p.

VALVERDE, F. M. (Coord). (1997) Bases para o planejamento da mineração de areia na Região Metropolitana de São Paulo. São Paulo. CPRM, 133p.+ mapas.

VELDE, B. (1992) Introduction to clay minerals :chemistry, origins, uses, and environmental significance. London; New York : Chapman \& Hall, 1st ed., 198p. 
VOTORANTIN CIMENTO S.A. (2002) Cimento cinza. [www document] URL http://www.votoran.com.br. Acesso em 20/05/2002.

WILSON, A. (1993) Cement and Concrete: Enviromental Considerations, In Environmental Building News - The leading Newsletter on Enviromentally Responsible Design and Construction. [www document] URL http://www.buildinggreeen.com. Acesso em 15/10/1999.

YAMAMOTO, J.K.; KIHARA, Y.; COIMBRA, A.M.; MONTANHEIRO, T.J. (1997) Environmental impact reduction on the production of blended Portland cement in Brazil. Environmental Geociences, 4(4):192-206.

ZAMPIERI, V.A. (1989) Mineralogia e mecanismos de ativação e reação das pozolanas de argilas calcinadas. Dissertação de Mestrado. IGc-USP., 191p.

ZAMPIERI, V.A. (1993) Cimento Portland aditivado com pozolanas de argilas calcinadas: fabricação, hidratação e desempenho mecânico. Tese de Doutoramento. IGc-USP., 233p.

ZANCHETTA, L. M. (2000) Características tecnológicas de argamassas elaboradas com diferentes tipos de areias. Monografia de Trabalho de Formatura. Instituto de Geociências - USP. 80p.

ZANDONADI, A.R. \& SOUZA SANTOS, P. (1978) Propriedades reológicas de montmorilonitas ou esmectitas brasileiras. Cerâmica, 25(106): 355-370.

ZANDONADI, A.R. (1974) Estudos recentes de argilas montmoriloníticas realizados no Instituto de Pesquisas Tecnológica de São Paulo. Cerâmica, 20(77): 77-97.

ZANDONADI, A.R. (1982) Uso de bentonitas de Campina Grande, Paraíba em Cerâmica. Cerâmica, 28(148): 127-149.

ZVYAGIN, B.B. (2001) Current problems with the nomenclature of phyllossilicates. Clay and Clay Minerals, 49(6): 492-499. 


\section{ANEXO 1}

\section{Descrição litológica das rochas amostradas}


Anexo 1: Descrição litológica das amostras

\begin{tabular}{|c|c|c|c|}
\hline & Amostra & Espessura (m) & Descrição \\
\hline 1 & $\mathrm{C} 2 \mathrm{~S}$ & 0,80 & $\begin{array}{l}\text { Lamito arenoso esverdeado, com porçóes arroxeadas, com níveis } \\
\text { mais siltosos, com clastos milimétricos de quartzo e feldspato } \\
\text { caulinizado. }\end{array}$ \\
\hline 2 & C3 & 1,00 & Lamito arenoso variegado. \\
\hline 3 & $\mathrm{C} 4 \mathrm{~A}$ & 1,50 & $\begin{array}{l}\text { Lamito verde com porções arroxeadas }(<1 \%) \text {, localmente siltoso. } \\
\text { Observa-se a precipitaçäo de óxido de ferro ao longo de } \\
\text { descontinuidades. }\end{array}$ \\
\hline 4 & $\mathrm{C} 4 \mathrm{~B}$ & 1,50 & $\begin{array}{l}\text { Lamito verde com porções arroxeadas }(<5 \%) \text {, localmente mais } \\
\text { arenosa. }\end{array}$ \\
\hline 5 & $\mathrm{C} 4 \mathrm{C}$ & 0,90 & Siltito arenoso verde maciço. \\
\hline 6 & C4D & 0,90 & Siltito arenoso verde maciço. \\
\hline 7 & C4E & 1,40 & $\begin{array}{l}\text { Lamito verde, localmente com clastos milimétricos de quartzo e } \\
\text { feldspato caulinizado. Observam-se níveis siltosos intercalados. }\end{array}$ \\
\hline 8 & $\mathrm{C} 4 \mathrm{E} / 2$ & 1,40 & Lamito verde sem clastos. \\
\hline 9 & C5A & 3,00 & $\begin{array}{l}\text { Lamito verde com porções arroxeadas }(<1 \%) \text {, localmente siltoso. } \\
\text { Observa-se a precipitação de óxido de ferro ao longo de } \\
\text { descontinuidades. }\end{array}$ \\
\hline 10 & C5B & 1,80 & Siltito arenoso verde macico. \\
\hline 11 & C6S & 0,80 & $\begin{array}{l}\text { Lamito roxo, raros clastos de quartzo e feldspato caulinizado. } \\
\text { Material bastante argiloso. }\end{array}$ \\
\hline 12 & $\mathrm{C} 6 \mathrm{~V}$ & 1,40 & $\begin{array}{l}\text { Lamito verde com percolação de material oxidado }(<5 \%) \text {. } \\
\text { Observam-se clastos milimétricos de feldspato caulinizado e } \\
\text { quartzo. Localmente apresenta-se mais arenoso. }\end{array}$ \\
\hline 13 & $\mathrm{C} 61$ & 0,30 & $\begin{array}{l}\text { Lamito roxo com clastos milimétricos de feldspato caulinizado e } \\
\text { quartzo. }\end{array}$ \\
\hline 14 & $\mathrm{C7}$ & 3,35 & $\begin{array}{l}\text { Lamito verde com percolação de material oxidado }(<5 \%) \text {. } \\
\text { Observam-se clastos milimétricos de feldspato caulinizado e } \\
\text { quartzo. Localmente apresenta-se mais siltoso. }\end{array}$ \\
\hline 15 & C9A & 1,60 & $\begin{array}{l}\text { Lamito verde, com estrias de escorregamento. Localmente } \\
\text { observa-se a percolação de óxido de ferro. }\end{array}$ \\
\hline 16 & $\mathrm{C9B}$ & 1,40 & $\begin{array}{l}\text { Lamito verde, com estrias de escorregamento. Localmente } \\
\text { observa-se a percolação de óxido de ferro. }\end{array}$ \\
\hline 17 & $\mathrm{C} 9 \mathrm{C}$ & 1,20 & $\begin{array}{l}\text { Lamito verde a levemente marrom, maciço, com estrias de } \\
\text { escorregamento. Localmente observa-se a percolação de óxido de } \\
\text { ferro. }\end{array}$ \\
\hline 18 & C9D & 1,0 & $\begin{array}{l}\text { Lamito com lamito arenoso verde maciço, com poucos clastos } \\
\text { submilimétricos de feldspato caulinizado. }\end{array}$ \\
\hline 19 & C10A & 1,00 & Lamito verde com percolação de óxido de ferro localizada. \\
\hline 20 & $\mathrm{C} 10 \mathrm{~B}$ & 0,30 & Lamito verde com percolação de óxido de ferro localizada. \\
\hline 21 & $\mathrm{C} 10 \mathrm{C}$ & 1,00 & $\begin{array}{l}\text { Lamito verde, com estrias de escorregamento e percolação de } \\
\text { óxido de ferro localizada. }\end{array}$ \\
\hline 22 & C10D & 0,80 & $\begin{array}{l}\text { Lamito verde com estrias de escorregamento e percolação de } \\
\text { óxido de ferro localizada. }\end{array}$ \\
\hline 23 & C10E & 1,00 & $\begin{array}{l}\text { Lamito verde com porções acastanhadas, com estrias de } \\
\text { escorregamento. }\end{array}$ \\
\hline 24 & $\mathrm{C} 10 \mathrm{~F}$ & 0,70 & $\begin{array}{l}\text { Lamito verde com muitas porções arroxeadas }(50 \%) \text { maciço, com } \\
\text { porções acastanhadas, com estrias de escorregamento. }\end{array}$ \\
\hline 25 & C11A & 1,00 & $\begin{array}{l}\text { Lamito verde, com estrias de escorregamento e percolação de } \\
\text { oxido de ferro localizada. }\end{array}$ \\
\hline 26 & $\mathrm{C} 11 \mathrm{~B}$ & 1,00 & $\begin{array}{l}\text { Lamito verde, com estrias de escorregamento e percolação de } \\
\text { óxido de ferro localizada. }\end{array}$ \\
\hline
\end{tabular}


Anexo 1: Descrição litológica das amostras - continuação

\begin{tabular}{|c|c|c|c|}
\hline & Amostra & Espessura (m) & Descrição \\
\hline 27 & $\mathrm{c} 11 \mathrm{C}$ & 1,00 & $\begin{array}{l}\text { Lamito verde, com estrias de escorregamento e percolação de } \\
\text { óxido de ferro localizada. }\end{array}$ \\
\hline 28 & C11D & 1,00 & $\begin{array}{l}\text { Lamito verde, localmente marrom, maciço, com estrias de } \\
\text { escorregamento e percolação de óxido de ferro localizada. }\end{array}$ \\
\hline 29 & C11E & 1,00 & $\begin{array}{l}\text { Lamito verde a levemente marrom, maciço, com estrias de } \\
\text { escorregamento e percolação de óxido de ferro localizada. }\end{array}$ \\
\hline 30 & $\mathrm{C} 11 \mathrm{~F}$ & 1,00 & $\begin{array}{l}\text { Lamito levemente marrom esverdeada, maciço, com estrias de } \\
\text { escorregamento e raras manchas de percolação de óxido de ferro. }\end{array}$ \\
\hline 31 & $\mathrm{C} 12$ & 1,20 & $\begin{array}{l}\text { Siltito arenoso alaranjado, com porções argilosas maciço, muita } \\
\text { percolação e precipitação de oxido de ferro. }\end{array}$ \\
\hline 32 & C13A & 1,20 & Siltito arenoso verde maciço sem percolação de óxido de ferro \\
\hline 33 & C13B & 0,80 & $\begin{array}{l}\text { Lamito verde, localmente acastanhada, com estrias de } \\
\text { escorregamento e muita percolação de óxido de ferro. }\end{array}$ \\
\hline 34 & $\mathrm{C} 13 \mathrm{C}$ & 1,30 & $\begin{array}{l}\text { Diamictito de matriz argilosa verde maciça, com muitos clastos } \mathrm{mm} \\
\text { de quartzo e feldspato. Raramente clastos subcentimétricos } \\
(0,5 \mathrm{~cm}) \text {. Ocorrem manchas de precipitação de óxido de ferro. }\end{array}$ \\
\hline 35 & C14A & 1,10 & $\begin{array}{l}\text { Siltito arenoso verde sem manchas de percolação de óxido de ferro } \\
\text { ou niveis argillíticos. }\end{array}$ \\
\hline 36 & C14B & 0,90 & $\begin{array}{l}\text { Lamito verde sem clastos observáveis. Observam-se estrias de } \\
\text { escorregamento, percolação e precipitação de óxido de ferro. }\end{array}$ \\
\hline 37 & $\mathrm{C} 14 \mathrm{C}$ & 1,50 & $\begin{array}{l}\text { Diamictito de matriz argilosa verde maciça, com muitos clastos } \mathrm{mm} \\
\text { de quartzo e feldspato. Raramente clastos subcentimétricos } \\
(0,5 \mathrm{~cm}) \text {. Ocorrem manchas de precipitação de óxido de ferro. }\end{array}$ \\
\hline 38 & C15 & 0,95 & $\begin{array}{l}\text { Lamito verde sem clastos observáveis. Observam-se estrias de } \\
\text { escorregamento, percolação e precipitação de óxido de ferro. }\end{array}$ \\
\hline 39 & $\mathrm{C} 16$ & 1,60 & $\begin{array}{l}\text { Lamito arenoso, com clastos submilimétricos de quartzo. O material } \\
\text { assemelha-se a um diamictito com clastos finos. }\end{array}$ \\
\hline 40 & C17A & 1,40 & $\begin{array}{l}\text { Lamito verde com porções arroxeadas, com estrias de } \\
\text { escorregamento. Localmente observam-se clastos submilimétricos. }\end{array}$ \\
\hline 41 & C17B & 1,20 & $\begin{array}{l}\text { Diamictito de matriz argilosa acastanhada maciça, com muitos } \\
\text { clastos mm de quartzo e feldspato. Raramente clastos } \\
\text { subcentimétricos }(0,5 \mathrm{~cm}) \text {. Ocorrem muitas manchas de } \\
\text { precipitação de óxido de ferro. }\end{array}$ \\
\hline 42 & C18A & 1,10 & $\begin{array}{l}\text { Lamito verde sem clastos observáveis. Observam-se estrias de } \\
\text { escorregamento, percolação e precipitação de óxido de ferro. }\end{array}$ \\
\hline 43 & C19AB & 1,50 & $\begin{array}{l}\text { Lamito verde sem clastos observáveis. Observam-se estrias de } \\
\text { escorregamento, percolação e precipitação de óxido de ferro. }\end{array}$ \\
\hline 44 & C19CD & 1,50 & $\begin{array}{l}\text { Lamito verde com clastos submilimétricos observáveis. Observam- } \\
\text { se estrias de escorregamento, percolação e precipitação de óxido } \\
\text { de ferro. }\end{array}$ \\
\hline
\end{tabular}




\section{ANEXO 2}

Resultados de análises granulométricas 
Anexo 2 - Distribuicão granulométrica ( $\mu \mathrm{m})$ - \% em massa retida acumulada

\begin{tabular}{|c|c|c|c|c|c|c|c|c|c|c|c|c|c|c|c|c|c|c|c|c|c|c|}
\hline Amostra & 500,00 & 250,00 & 177,00 & 150,00 & 65,51 & 41,00 & 35,56 & 30,53 & 26,20 & 22,49 & 19,31 & 16,57 & 14,22 & 12,21 & 10,48 & 9,00 & 7,72 & 6,63 & 5,69 & 4,88 & 4,19 & 3,60 \\
\hline C2S & 1,04 & 2,08 & 2,75 & 3,21 & 8,50 & 12,98 & 2,40 & 2,37 & 2,25 & 2,10 & 1,97 & 1,98 & 2,01 & 2,08 & 2,18 & 2,31 & 2,43 & 2,54 & $\frac{2,62}{2,62}$ & 2,66 & 2,67 & 2,65 \\
\hline $\mathrm{C} 4 \mathrm{~A}$ & 0,22 & 0,44 & 0,65 & 0,82 & 4,33 & 9,30 & 2,67 & 2,82 & 2,88 & 2,88 & 2,85 & 2,86 & 2,97 & 3,12 & 3,31 & 3,53 & 3,75 & 3,95 & 4,10 & 4,16 & 4,13 & 4,01 \\
\hline $\mathrm{C} 4 \mathrm{~B}$ & 0,06 & 0,19 & 0,36 & 0,53 & 6,81 & 13,81 & 3,85 & 3,94 & 3,89 & 3,76 & 3,71 & 3,68 & 3,70 & 3,76 & 3,86 & 3,96 & 4,02 & 4,01 & 3,91 & 3,72 & 3,44 & 3,10 \\
\hline $\mathrm{C} 5 \mathrm{~A}$ & 0,29 & 0,48 & 0,67 & 0,81 & 2,88 & 6,76 & 2,41 & 2,66 & 2,86 & 3,01 & 3,14 & 3,27 & 3,41 & 3,56 & 3,70 & 3,82 & 3,91 & 3,94 & 3,92 & 3,84 & 3,70 & 3,54 \\
\hline $\mathrm{C} 5 \mathrm{~B}$ & 0,72 & 1,71 & 2,83 & 3,52 & 8,85 & 12,72 & 1,37 & 1,51 & 1,67 & 1,87 & 2,15 & 2,51 & 2,96 & 3,44 & 3,86 & 4,22 & 4,48 & 4,59 & 4,56 & 4,37 & 4,05 & 3,64 \\
\hline $\mathrm{C} 6 \mathrm{~V}$ & 1,45 & 2,24 & 2,50 & 2,58 & 3,96 & 6,58 & 1,62 & 1,84 & 2,05 & 2,26 & 2,49 & 2,75 & 3,04 & 3,35 & 3,57 & 3,76 & 3,88 & 3,91 & 3,85 & 3,70 & 3,47 & 3,21 \\
\hline C11A & 0,11 & 0,22 & 0,28 & 0,32 & 0,90 & 3,45 & 1,60 & 1,91 & 2,22 & 2,54 & 2,88 & 3,25 & 3,65 & 4,05 & 4,43 & 4,63 & 4,76 & 4,80 & 4,73 & 4,55 & 4,28 & 3,96 \\
\hline C11B & 0,04 & 0,08 & 0,12 & 0,14 & 0,40 & 1,85 & 0,90 & 1,08 & 1,26 & 1,46 & 1,69 & 1,97 & 2,33 & 2,76 & 3,24 & 3,73 & 4,19 & 4,43 & 4,63 & 4,74 & 4,75 & 4,70 \\
\hline C11C & 0,02 & 0,05 & 0,08 & 0,09 & 0,22 & 1,03 & 0,48 & 0,58 & 0,69 & 0,82 & 1,00 & 1,23 & 1,54 & 1,95 & 2,45 & 3,02 & 3,61 & 4,19 & 4,70 & 5,04 & 5,24 & 5,39 \\
\hline C11D & 0,05 & 0,10 & 0,16 & 0,19 & 0,62 & 2,09 & 0,85 & 0,90 & 0,94 & 1,00 & 1,12 & 1,31 & 1,60 & 2,00 & 2,48 & 3,01 & 3,54 & 4,03 & 4,43 & 4,59 & 4,71 & 4,78 \\
\hline C11E & 0,03 & 0,06 & 0,09 & 0,10 & 0,20 & 1,17 & 0,59 & 0,71 & 0,81 & 0,92 & 1,08 & 1,30 & 1,61 & 2,03 & 2,53 & 3,09 & 3,63 & 4,12 & 4,50 & 4,62 & 4,70 & 4,73 \\
\hline $\mathrm{C} 11 \mathrm{~F}$ & 0,08 & 0,15 & 0,19 & 0,20 & 0,25 & 0,78 & 0,56 & 0,78 & 1,02 & 1,29 & 1,62 & 2,01 & 2,48 & 3,02 & 3,59 & 4,17 & 4,68 & 5,08 & 5,15 & 5,18 & 5,11 & 4,97 \\
\hline $\mathrm{C} 13 \mathrm{~A}$ & 0,21 & 2,71 & 5,96 & 7,73 & 17,18 & 20,22 & 1,07 & 1,19 & 1,31 & 1,46 & 1,64 & 1,88 & 2,15 & 2,43 & 2,69 & 2,90 & 3,04 & 3,08 & 3,03 & 2,87 & 2,62 & 2,32 \\
\hline C13B & 0,06 & 0,11 & 0,15 & 0,18 & 0,64 & 2,88 & 1,36 & 1,64 & 1,91 & 2,19 & 2,48 & 2,79 & 3,14 & 3,52 & 3,90 & 4,22 & 4,41 & 4,54 & 4,59 & 4,54 & 4,41 & 4,23 \\
\hline C18A & 0,04 & 0,12 & 0,21 & 0,25 & 0,80 & 3,00 & 1,31 & 1,56 & 1,82 & 2,10 & 2,41 & 2,75 & 3,13 & 3,52 & 3,92 & 4,28 & 4,43 & 4,53 & 4,56 & 4,49 & 4,34 & 4,14 \\
\hline C19AB & 0,05 & 0,25 & 0,45 & 0,56 & 1,50 & 3,47 & 1,19 & 1,39 & 1,62 & 1,86 & 2,14 & 2,47 & 2,84 & 3,26 & 3,69 & 4,09 & 4,30 & 4,46 & 4,53 & 4,50 & 4,38 & 4,20 \\
\hline C19CD & 0,24 & 0,37 & 0,44 & 0,50 & 1,42 & 3,61 & 1,20 & 1,40 & 1,59 & 1,78 & 2,00 & 2,27 & 2,61 & 3,01 & 3,46 & 3,91 & 4,21 & 4,46 & 4,62 & 4,67 & 4,62 & 4,49 \\
\hline
\end{tabular}

Anexo 2 - Distribuição granulométrica $(\mu \mathrm{m})$ - \% em massa retida acumulada - Continuação

\begin{tabular}{|c|c|c|c|c|c|c|c|c|c|c|c|c|c|c|c|c|c|c|c|c|c|c|c|c|c|c|c|}
\hline nostral & 3,09 & 2,65 & 2,28 & 1,95 & 1,68 & 1,44 & 1,24 & 1,06 & 0,91 & 0,78 & 0,67 & 0,58 & 0,49 & 0,42 & 0,36 & $0, \mathbf{3 1}$ & 0,27 & 0,23 & 0,20 & 0,17 & 0,15 & 0,13 & 0,11 & 0,09 & 0,08 & 0,07 & 0,06 \\
\hline $\mathrm{C} 2 \mathrm{~S}$ & 2,63 & 2,63 & 2,64 & 2,65 & 2,65 & 2,62 & 2,54 & 2,41 & 2,21 & 2,00 & 1,71 & 1,37 & 1,09 & 0,85 & 0,59 & 0,44 & 0,34 & 0,24 & 0,16 & 0,12 & 0,09 & 0,07 & 0,06 & 0,04 & 0,03 & 0,02 & \\
\hline C4A & 3,82 & 3,58 & 3,33 & 3,06 & 2,78 & 2,51 & 2,23 & 1,96 & 1,67 & 1,39 & 1,13 & 0,87 & 0,66 & 0.49 & 0.32 & & 0,14 & & & & & & & & & & 0,00 \\
\hline$\overline{C A B}$ & 274 & 239 & 2.07 & 180 & 15 & 136 & $\overline{1.19}$ & & $\overline{0.8}$ & 0.74 & 0.61 & 048 & & & & & & 0.04 & & & & & 0.00 & & 00 & 00 & \\
\hline$\overline{C 5 A}$ & 3,37 & 3,21 & 3,09 & 2,98 & 2,87 & 2,75 & 2,60 & 2,41 & 2,18 & 1,93 & 1,64 & 1,29 & 1,01 & 77 & 0,51 & 0,35 & 0,23 & 0,13 & 0,06 & 02 & & 0,00 & 0,00 & 0,00 & 0,00 & 0,00 & 0,00 \\
\hline C5B & 3,20 & 2,77 & 2,38 & 2,02 & 1,71 & 1,44 & 1,20 & 0,99 & 0,79 & 0,61 & 0,47 & 0,33 & 0,23 & 0,15 & 0,07 & 0,03 & 0,01 & 0,00 & 0,00 & 0,00 & 0,00 & 0,00 & 0,00 & 0,00 & 0,00 & 0,00 & 0,00 \\
\hline & 2,96 & 2,74 & 2,58 & 2,47 & 2,39 & & 2,25 & 2,1 & 2,02 & & 1,68 & & & & & & & & & & & & & & & & \\
\hline C11A & 3,65 & 3,38 & 3,17 & 3,03 & 2,91 & 2,81 & 2,70 & 2,56 & 2,35 & 2,15 & 1,90 & 1,5 & 1,24 & & 0,66 & 0,49 & 0,39 & 0.25 & 0,14 & 0,07 & 0,0 & 0.0 & 0,01 & 0,00 & 100 & 0,00 & 00 \\
\hline C11E & 4,61 & 4,52 & 4,43 & 4,35 & 4,24 & 4,10 & 3,90 & 3,62 & 3,27 & 2,90 & 2,45 & 1,94 & 1,52 & 1,16 & 0,78 & 0,56 & 0,40 & 0,26 & 0,16 & 0,10 & & 0,0 & 0,03 & & 1,02 & 0,01 & 0,00 \\
\hline & 5,48 & 5,53 & 5,53 & 5,46 & 5,30 & 5,05 & 4,70 & 4,26 & 3,71 & 3,17 & 2,58 & 1,5 & 1,44 & & 0,63 & 39 & 0,24 & 0,11 & 0,04 & & 0,0 & 0,00 & 0,00 & 0,00 & 0,00 & 0,00 & 00 \\
\hline C11D & 4,82 & 4,83 & 4,83 & 4,81 & 4,74 & 4,62 & 4,41 & 4,11 & 3,7 & 3,3 & 2,82 & 2,2 & 1,7 & & & & & & & & & & 20 & & 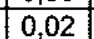 & & \\
\hline $\mathrm{C}_{\mathrm{C}}$ & $\frac{4,0<}{4,74}$ & $\frac{4,05}{4,75}$ & $\frac{4,00}{4,76}$ & $\frac{4,01}{4,78}$ & $\frac{4,47}{4,76}$ & $\frac{4,02}{4,68}$ & $\frac{4,41}{4,53}$ & $\frac{4,29}{4,29}$ & $\frac{0,1<}{3,93}$ & $\frac{3,5}{3,5}$ & $\frac{2,02}{3,09}$ & $\frac{2,20}{2,47}$ & $\frac{1, r 1}{1,99}$ & $\frac{1,56}{1,5 !}$ & 1,0 & 0,79 & 16. & 0,41 & 0,2 & & & & 0,0 & & & & \\
\hline & 4,78 & 4,59 & 4,41 & & 4,09 & 3,91 & & 3,43 & & 2,74 & & & & & & & & & & & & & & & & & \\
\hline $\mathrm{C} 13 \mathrm{~A}$ & 2,00 & 1,69 & 1,40 & 1,15 & 0,94 & 0,76 & 0,62 & 0,49 & 0,38 & 0,29 & 0,22 & 0,15 & 0,10 & 0,07 & 0,03 & 0,01 & 0,00 & 0,00 & 0,00 & 0,00 & 0,0 & & 0,00 & 0,0 & 0.0 & 0,00 & 0,00 \\
\hline C13B & 4,03 & 30 & & 3,58 & 3,47 & $\frac{19}{321}$ & $\frac{5,25}{3,19}$ & & & 2,45 & $\frac{2,21}{2,11}$ & & 1,36 & & & & & 0,29 & & & & & & & & & \\
\hline & 3,95 & 3,78 & 3,66 & 3,57 & 3,49 & 3,40 & 3,27 & & & & 2,19 & & 1,39 & & $\overline{0,7}$ & 0,53 & 0,40 & 0.26 & 0,15 & 0,09 & & & 0,02 & 0,02 & & 0,01 & 0.00 \\
\hline $9 A B$ & 4,00 & 3,82 & 3,68 & 3,57 & 3.48 & 3,37 & 3,24 & 3,06 & 2,81 & 2,56 & 2,22 & 1,80 & 1,45 & 1,15 & 0,80 & 0,59 & 0,45 & 0,30 & 0.18 & 0,11 & 0,07 & 0,04 & 0,03 & 0,01 & 0,01 & 0,00 & 0,00 \\
\hline $19 \mathrm{CD}$ & 4,33 & \begin{tabular}{|l|l|}
4,17 \\
\end{tabular} & 4,03 & 3,89 & 3,75 & 3.59 & 3,38 & 3,13 & 2,80 & 2,47 & \begin{tabular}{|l|}
2,08 \\
\end{tabular} & 1,63 & 1,27 & 0,96 & 0,62 & 0,43 & \begin{tabular}{|l|}
0,29 \\
\end{tabular} & 0.17 & 0.08 & 0,04 & 0,01 & & & & 0,00 & & 0,0 \\
\hline
\end{tabular}




\section{ANEXO 3 \\ Minerações de areia do Bairro do Taboão, Mogi das Cruzes (SP)}




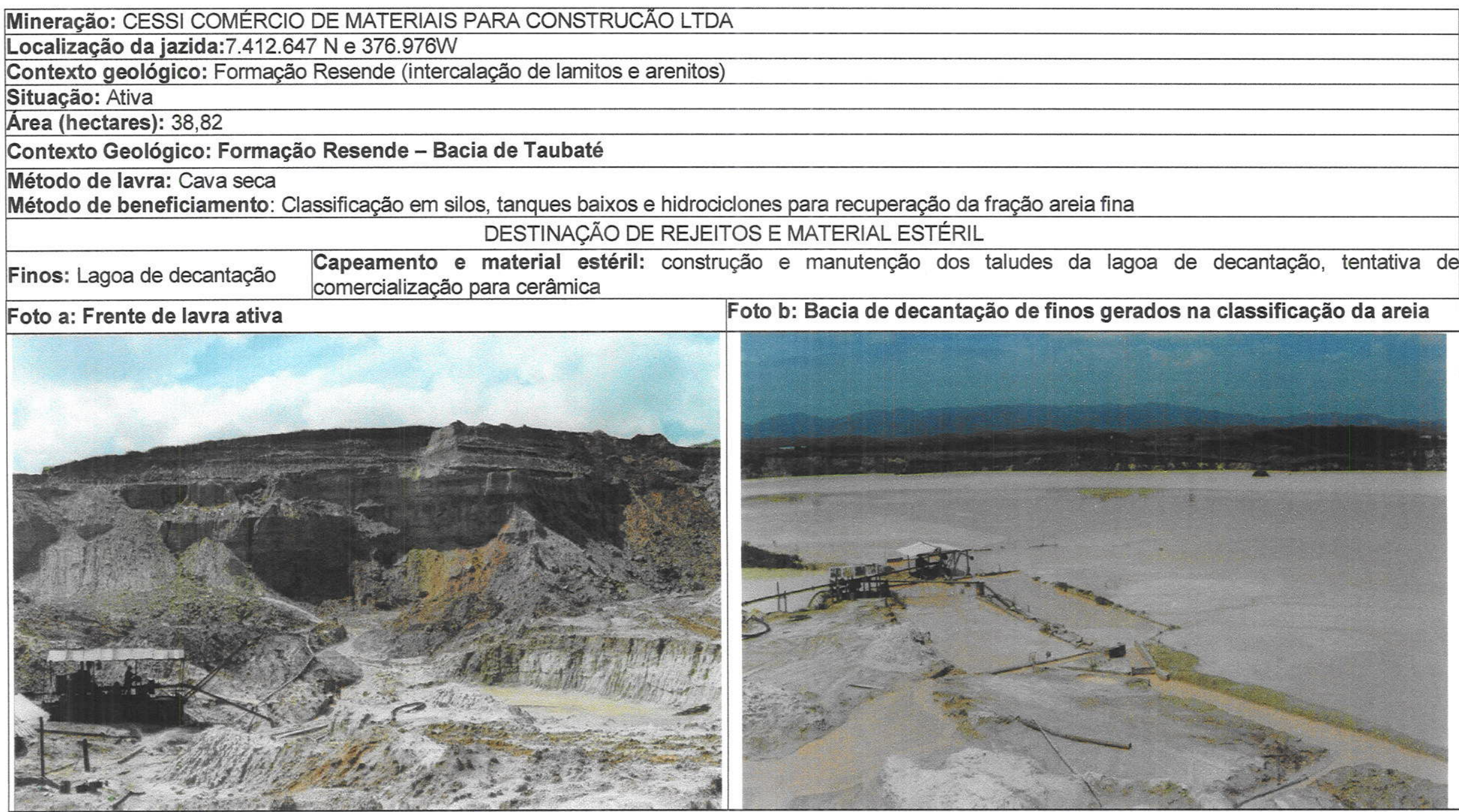


Mineração: EMPRESA DE MINERAÇÃO J.B.S. LTDA (I)

Localização da jazida: $7.412 .138 \mathrm{~N} ; 377.790 \mathrm{~W}$

Contexto geológico: Formação Resende (intercalação de lamitos e arenitos)

Situação: Ativa

Área (hectares): 49,43

Contexto Geológico: Formação Resende - Bacia de Taubaté

Método de lavra: Cava seca

Método de beneficiamento: Classificação em silos com uma lavagem. Atualmente instalando hidrociclone para recuperação da fração areia fina.

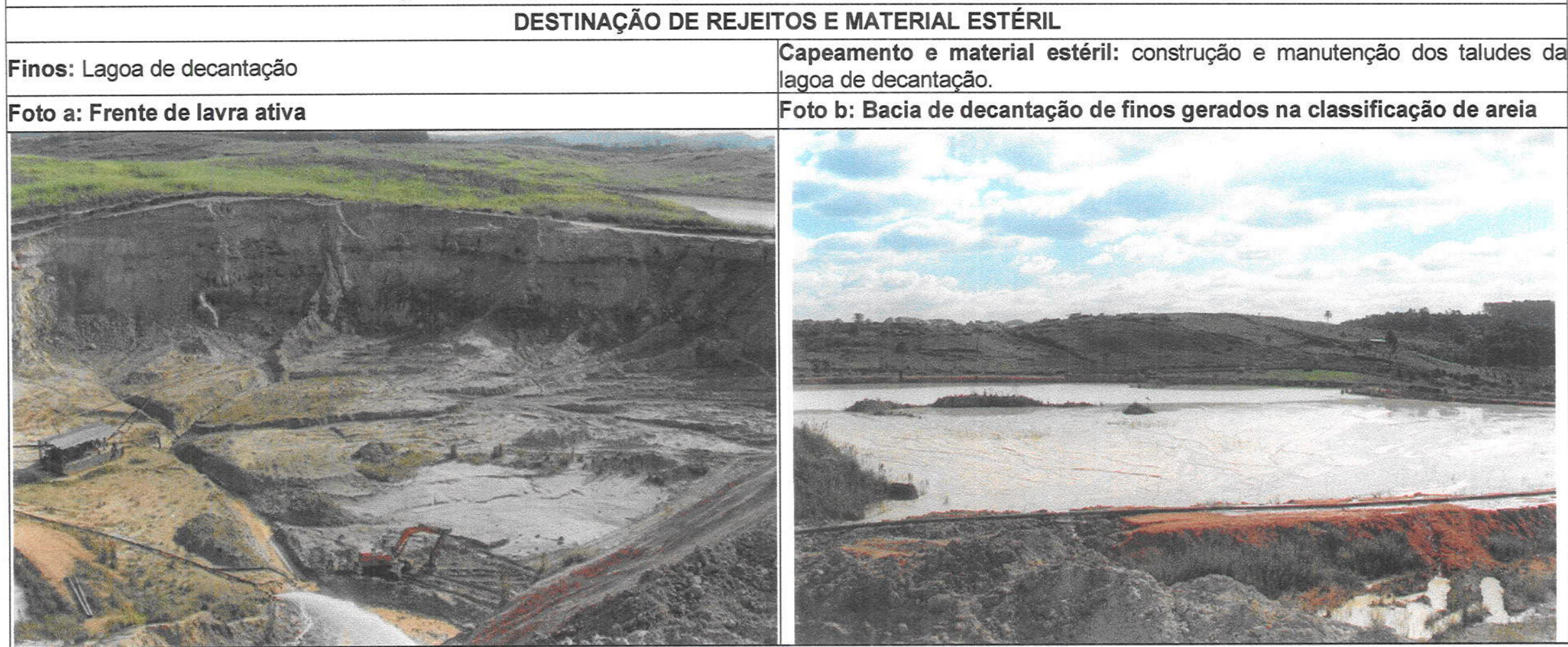




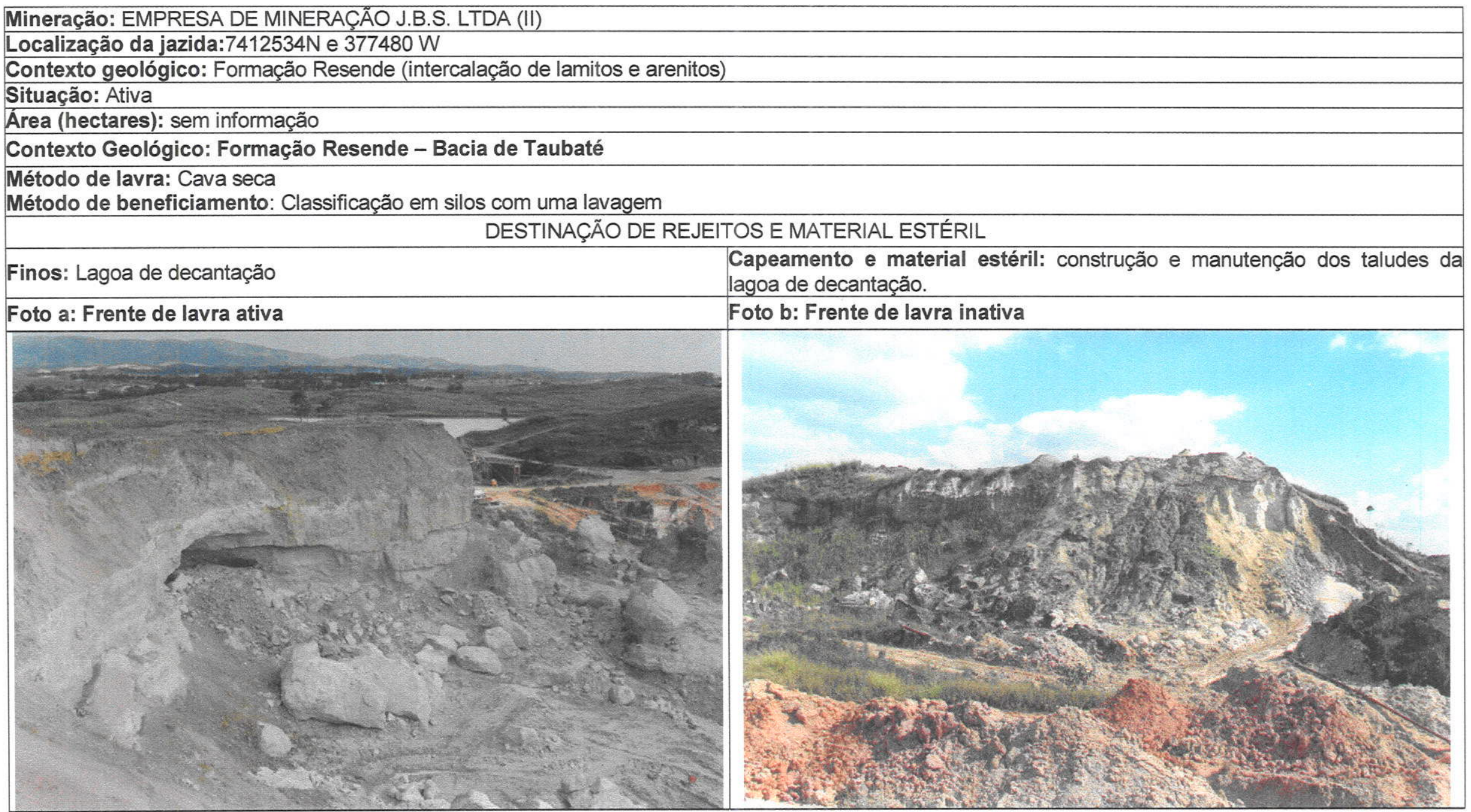


Mineração: MINERAÇÃO DO Sr RAUL LERÁRIO

Localização da jazida:7.411.399N e 377.910W

Contexto geológico: Formação Resende (intercalação de lamitos e arenitos)

Situação: Ativa

Área (hectares): não declarado

Contexto Geológico: Formação Resende - Bacia de Taubaté

Método de lavra: Cava seca

Método de beneficiamento: Classificacão em silos

DESTINAÇÃO DE REJEITOS E MATERIAL ESTÉRIL

\begin{tabular}{l|l} 
Finos: Lagoa de decantação & $\begin{array}{l}\text { Capeamento e mate } \\
\text { lagoa de decantação }\end{array}$ \\
\hline
\end{tabular}

Mineracão: ITAQUAREIA INDÚSTRIA EXTRATIVA DE MINÉRIOS

Localização da jazida: $7.413 .000 \mathrm{~N}$ e $377.781 \mathrm{~W}$

Contexto geológico: Formação Resende (intercalação de lamitos e arenitos)

Situacão: Ativa

Área (hectares): não declarado

Contexto Geológico: Formação Resende - Bacia de Taubaté

Método de lavra e beneficiamento: Cava seca

DESTINAÇÃO DE REJEITOS E MATERIAL ESTÉRIL

Finos: Lagoa de decantação $\quad$ Capeamento e material estéril: não declarado 
Mineração: PORTO E EXTRAÇÅO DE AREIA TRẾS COROAS LTDA

Localização da jazida:7.409.357N e 375.678W

Contexto geológico: Formação Resende (intercalação de lamitos e arenitos)

Situação: Ativa

Área (hectares): 18,52

Contexto Geológico: Formação Resende - Bacia de Taubaté

Método de lavra: Cava seca

Método de beneficiamento: Classificação em silos e tanques baixos

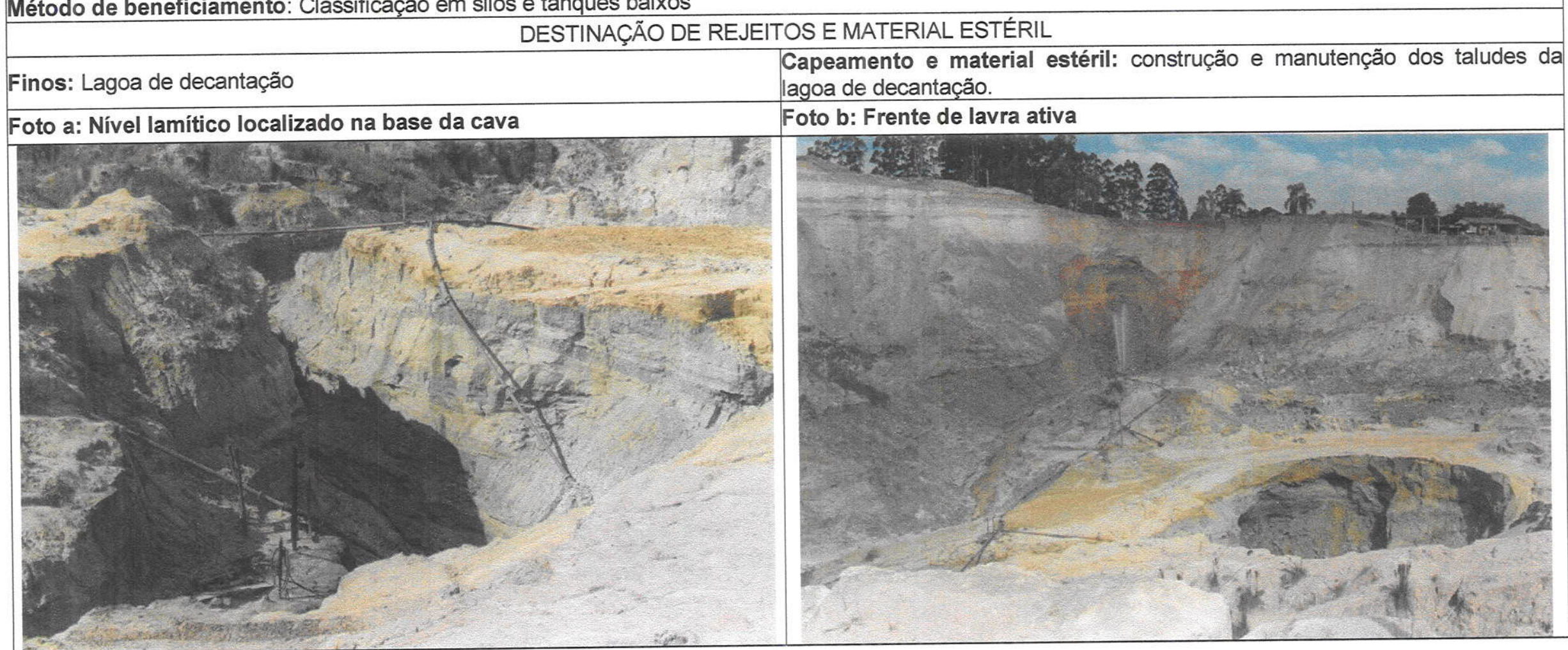


Mineração: DUTRA EXTRAÇÃO DE AREIA LTDA

Localização da jazida:Bairro do Taboão (coordenadas: 7.410.040N, 376.107W)

Contexto geológico: Formação Resende (intercalação de lamitos e arenitos)

Situação: Ativa

Área (hectares): 15,91

Contexto Geológico: Formação São Paulo - Bacia de Taubaté

Método de lavra: Cava seca

Método de beneficiamento: Classificação em silos

DESTINAÇÃO DE REJEITOS E MATERIAL ESTÉRIL

Finos: Lagoa de decantação

Capeamento e material estéril: construção e manutenção dos taludes da agoa de decantação.

Foto a: Frente de lavra ativa

Foto b: Bacia de decantação de finos gerados na classificação de areia

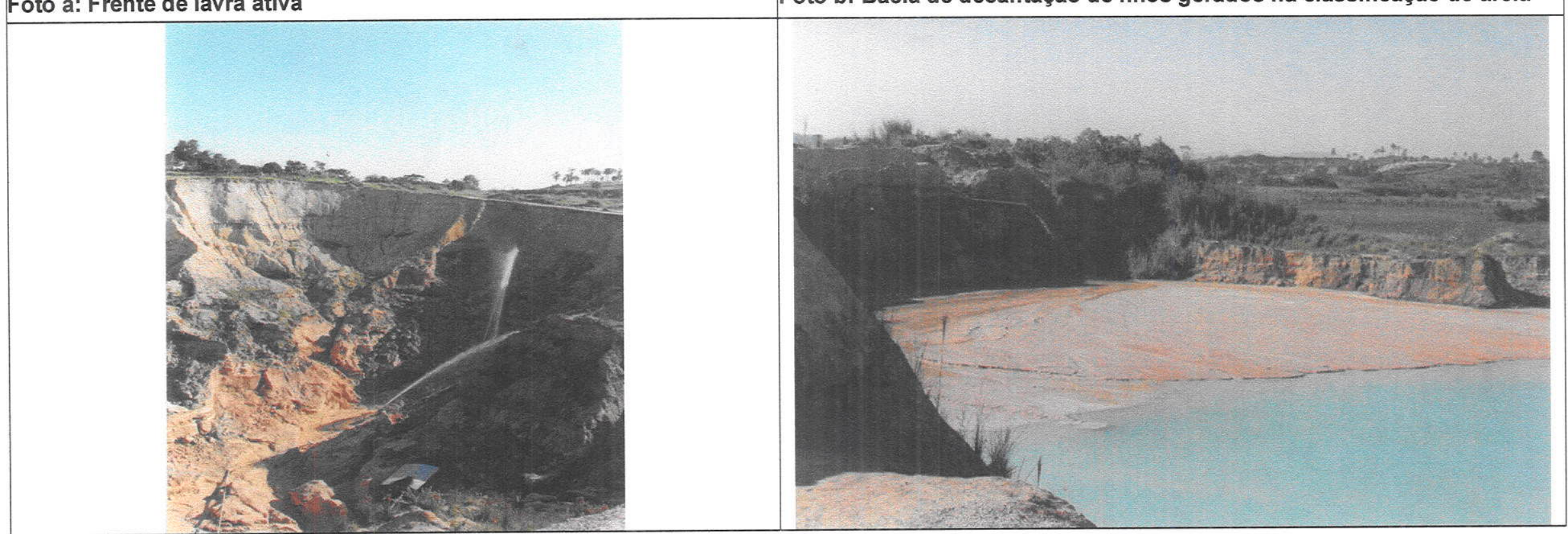


Mineração: JUSTO EXTRAÇẢO DE AREIA LTDA

Localização da jazida: ESTRADA DO LAMBARI,BAIRRO TABOAO

Contexto geológico: Formação Resende (intercalação de lamitos e arenitos)

Situação: Ativa

Área (hectares): 8,92

Contexto Geológico: Formação São Paulo - Bacia de Taubaté

Método de lavra: Cava seca

Método de beneficiamento: Classificação em silos e tanques baixos no solo

DESTINAÇÃO DE REJEITOS E MATERIAL ESTÉRIL

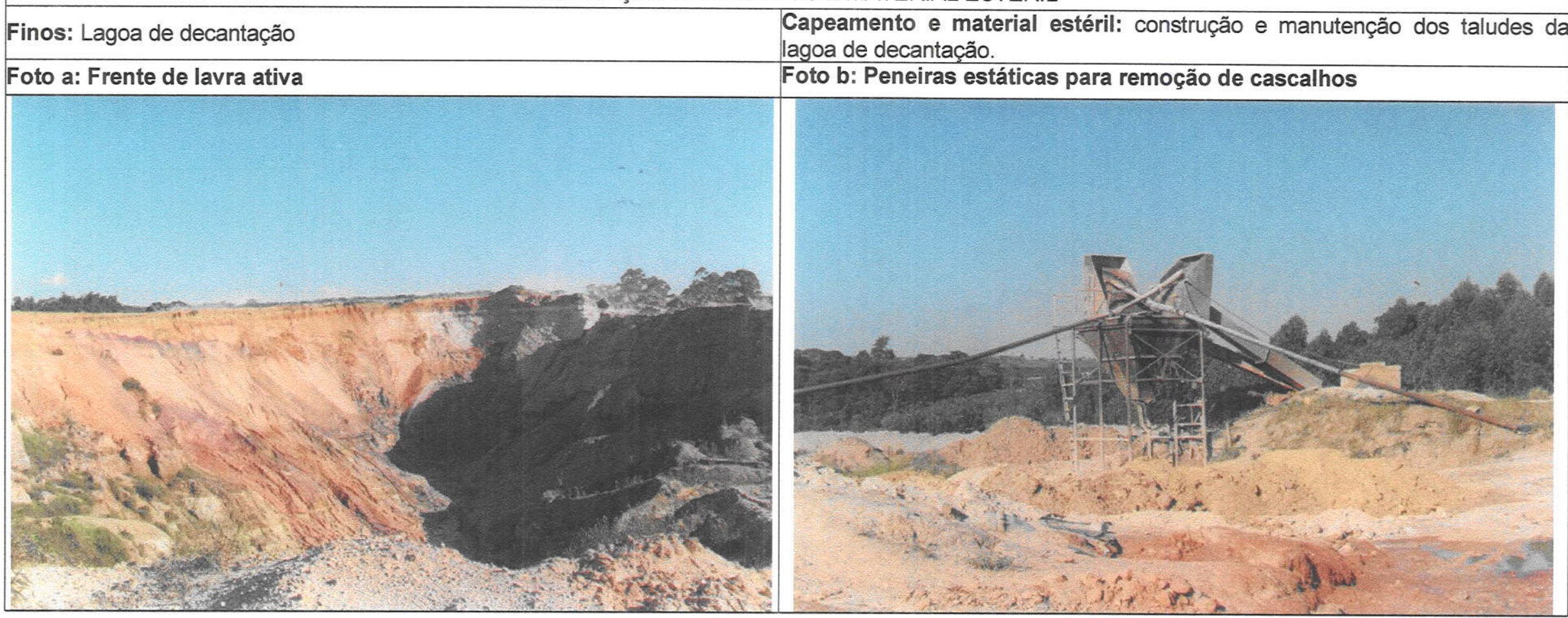


ANEXO 4

Resultados dos ensaios cerâmicos 
ANEXO 4: Resultados de ensaios cerâmicos: Amostra C2S

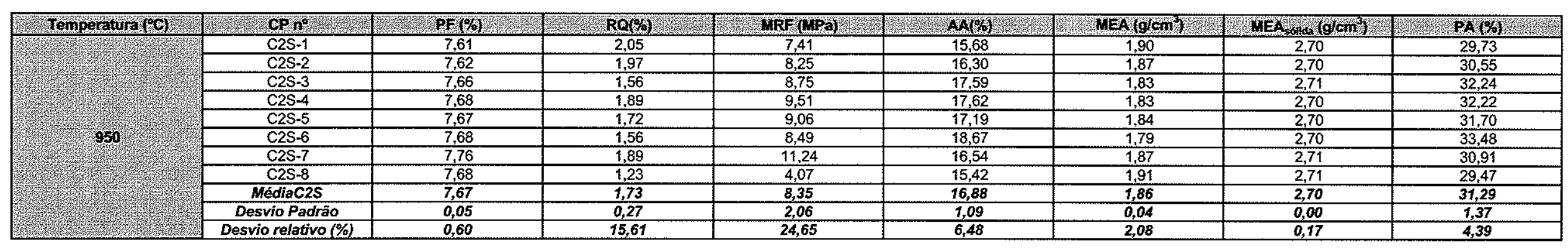

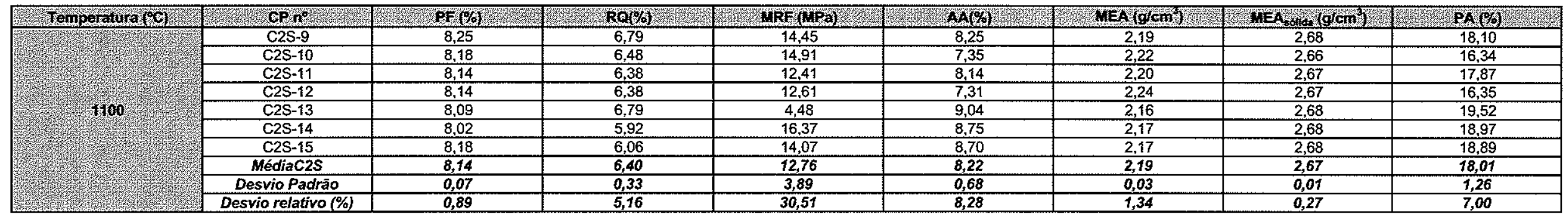

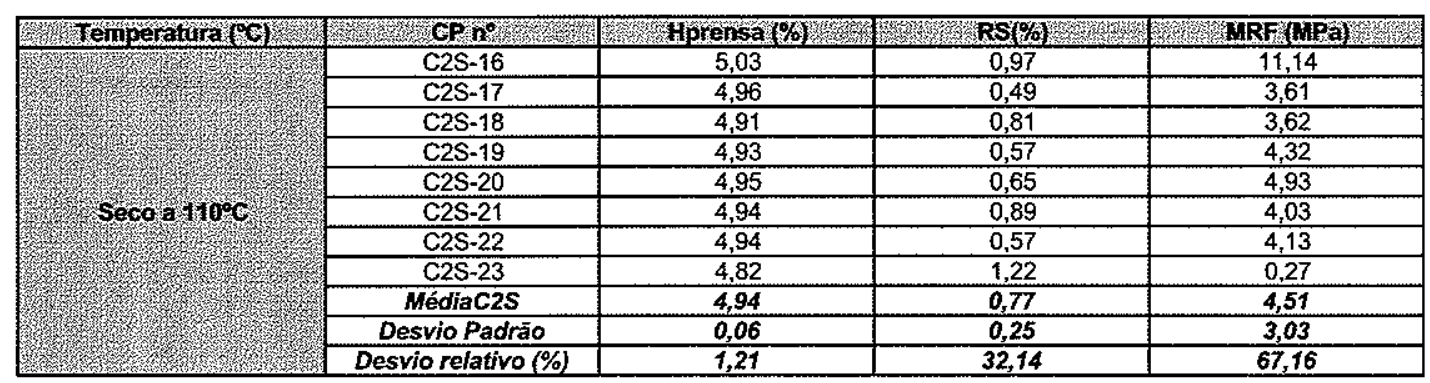

\begin{tabular}{l}
\multicolumn{1}{|c|}{ Legenda } \\
CP: corpo de prova \\
PF: Perda ao fogo \\
RQ: Retraçāo linear de queima \\
RQ: Retração linear de secagem \\
MRF: Módulo de ruptura à flexāo \\
AA: Absorção de água \\
MEA: Massa especifica aparente da parte sólida \\
MEA: Massa especíica aparente \\
PA: Porosisade aparente \\
Hprensa: Umidade de prensagem
\end{tabular}


ANEXO 4: Resultados de ensaios cerâmicos: Amostra C4A

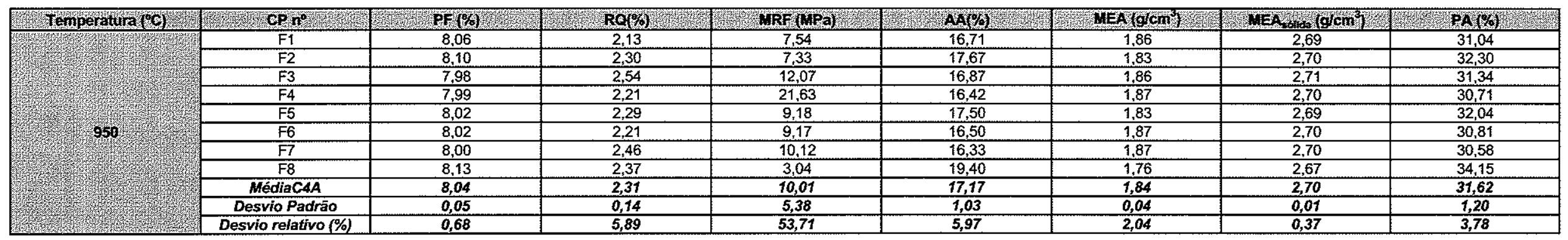

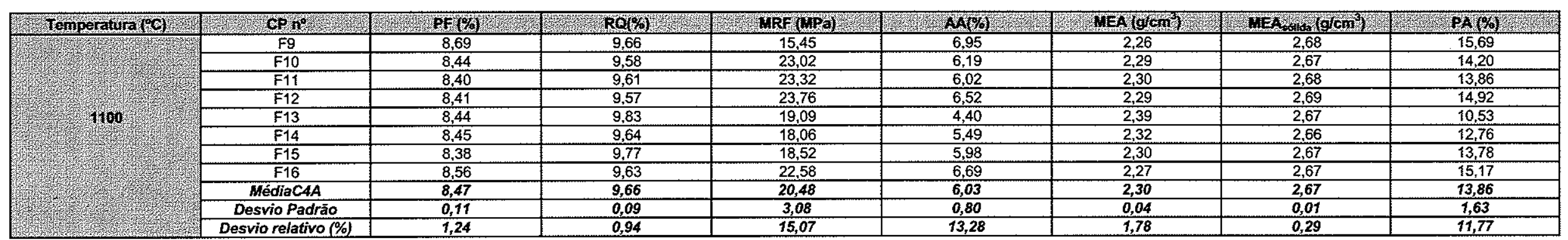

\begin{tabular}{|c|c|c|c|c|c|c|}
\hline Temperatura \&G] & A & Whensa (\%) & T. & URF (MPa) & \multirow{9}{*}{$\begin{array}{l}\text { CP: corpo de prova } \\
\text { PF: Perda ao fogo } \\
\text { RQ: Retração linear de queima } \\
\text { RQ: Retração linear de secagem } \\
\text { MRF: Módulo de ruptura à fiexāo } \\
\text { AA: Absorçāo de água }\end{array}$} & \multirow{10}{*}{$\begin{array}{l}\text { MEA: Massa especifica aparente } \\
\text { PA: Porosisade aparente } \\
\text { Hprensa: Umidade de prensagem }\end{array}$} \\
\hline \multirow{9}{*}{$\operatorname{secoda} 110^{\circ} \mathrm{C}$} & F17 & 5,34 & 0,89 & 2,00 & & \\
\hline & F18 & 5,18 & 0,81 & 4,29 & & \\
\hline & F19 & 5,16 & 0,49 & 3,61 & & \\
\hline & F20 & 5,06 & 0,57 & 3,68 & & \\
\hline & F21 & 5,03 & 0,65 & 3,97 & & \\
\hline & F22 & 5,16 & 0,65 & 3,89 & & \\
\hline & MédiaC4A & 5,15 & 0,68 & 3,57 & & \\
\hline & Desvio Padrão & 0,11 & 0,15 & 0,81 & & \\
\hline & Desvio relativo (\%) & 2,13 & 22,31 & 22,56 & MEA: Massa especifica aparente da parte sólida & \\
\hline
\end{tabular}


ANEXO 4: Resultados de ensaios cerâmicos: Amostra C4B

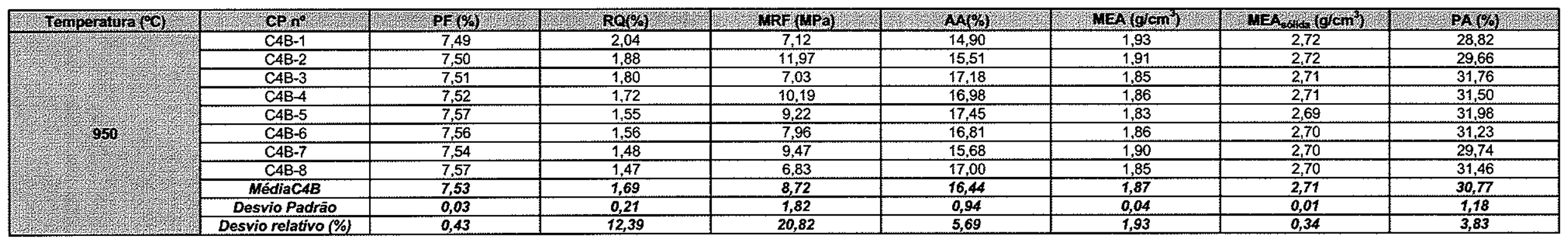

\begin{tabular}{|c|c|c|c|c|c|c|c|c|}
\hline Tenperatura $(\mathrm{C})$ & Gp r p & $P F(\%)$ & Ro/\% & MRf MPa & $\mathrm{No}(\mathrm{s} \%$ & 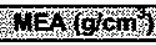 & MEA & PA (ख) \\
\hline \multirow{10}{*}{1100} & C4B-9 & 8,08 & 7,53 & 14,80 & 8,34 & 2,20 & 2,69 & 18,35 \\
\hline & CAB-10 & 8,02 & 7,62 & 18,58 & 6,99 & 2,27 & 2,69 & $\{5,85$ \\
\hline & $\mathrm{C} 4 \mathrm{~B}-11$ & 8.16 & 7,52 & 14,48 & 8,75 & 2,17 & 2,69 & 19,02 \\
\hline & $\mathrm{C} 4 \mathrm{~B}-12$ & 8,09 & 7.54 & 18,27 & 7,46 & 2,23 & 2,68 & 16,67 \\
\hline & C4B-13 & 8,12 & 7.40 & 16,36 & 8,22 & 2,20 & 2,69 & 18,09 \\
\hline & $\mathrm{C} 4 \mathrm{~B}-14$ & 8,21 & 7,53 & 16,11 & 8,47 & 2,19 & 2,69 & 18,58 \\
\hline & C4B-15 & 8,40 & 7.38 & 13,97 & 8.18 & 2,20 & 2,68 & 17,98 \\
\hline & MédiaC4B & 8,15 & 7,50 & 16,08 & 8,06 & 2,21 & 2,69 & 17,79 \\
\hline & Desvio Padrāo & 0,12 & 0,09 & 1,81 & 0,61 & 0,03 & 0,01 & 1,12 \\
\hline & Desvio relativo (\%) & 1,52 & 1,14 & 11,28 & 7,61 & 1,40 & 0,23 & 6,32 \\
\hline
\end{tabular}

\begin{tabular}{|c|c|c|c|c|}
\hline Temperaturaral & $\cosh ^{\circ}$ & Aprensaro & RSI\% & MRF(MPa) \\
\hline \multirow{10}{*}{ Seco a $10^{\circ} \mathrm{C}$} & $\mathrm{C} 4 \mathrm{~B}-17$ & 4,13 & 0,41 & 3,08 \\
\hline & C4B-18 & 4,11 & 0,49 & 3,06 \\
\hline & $\mathrm{C} 4 \mathrm{~B}-19$ & 4,20 & 0,49 & 2,77 \\
\hline & $\mathrm{C} 4 \mathrm{~B}-20$ & 4,15 & 0,88 & 2,79 \\
\hline & C4B-21 & 4,06 & 0,49 & 3.56 \\
\hline & C4B-22 & 4,08 & 0,65 & 3,32 \\
\hline & C4B-23 & 3,99 & 0,73 & 1.65 \\
\hline & MédiaC4B & 4,10 & 0,59 & 2,89 \\
\hline & Desvio Padrāo & 0,07 & 0,17 & 0,61 \\
\hline & Desvio relativo (\%) & 1,63 & 28,56 & 21,20 \\
\hline
\end{tabular}

Legenda
CP: corpo de prova
PF: Perda ao fogo
RQ: Retraçäo linear de queima
RQ: Retraçäo linear de secagem
MRF: Módulo de ruptura à flexāo
AA: Absorção de água
MEA: Massa especifica aparente da parte sólida
MEA: Massa especifica aparente
PA: Porosisade aparente
Hprensa: Umidade de prensagem


ANEXO 4: Resultados de ensaios cerâmicos: Amostra C5A

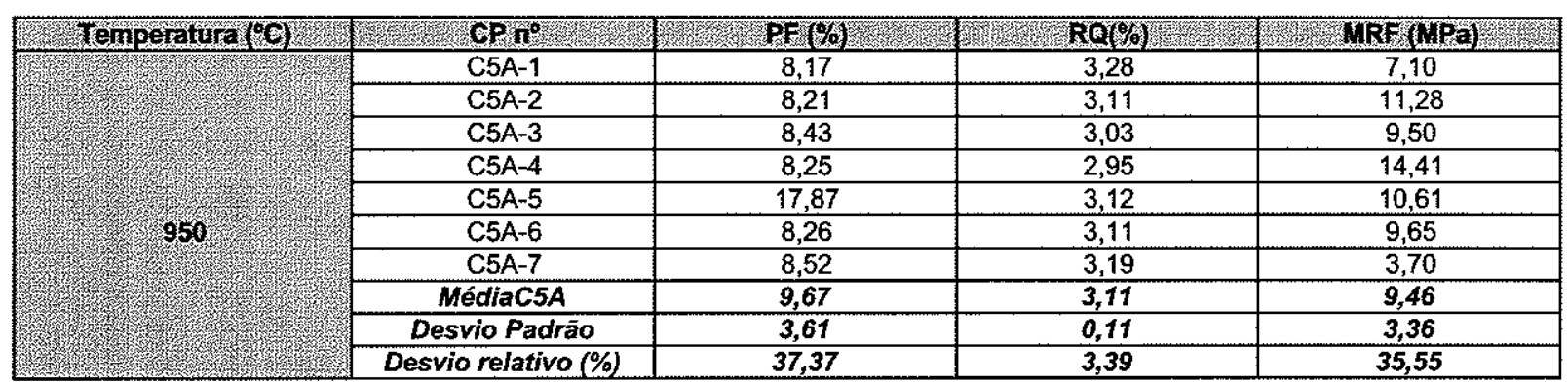

\begin{tabular}{|c|c|c|c|c|}
\hline Temperatura (c) & GPI & PEF $1 \%$ & RQF\%) & NRF (MPa) \\
\hline \multirow{10}{*}{1100} & C5A-8 & 8,99 & 12,46 & 24,09 \\
\hline & C5A-9 & 8,99 & 12,44 & 28,45 \\
\hline & $\mathrm{C} 5 \mathrm{~A}-10$ & 8,98 & 12,50 & 20,19 \\
\hline & $\mathrm{C} 5 \mathrm{~A}-11$ & 8,91 & 12,60 & 37,03 \\
\hline & $\mathrm{C} 5 \mathrm{~A}-12$ & 8,95 & 12,44 & 22,54 \\
\hline & $\mathrm{C} 5 \mathrm{~A}-13$ & 8,99 & 12,36 & 30,15 \\
\hline & $\mathrm{C} 5 \mathrm{~A}-14$ & 9,03 & 12,40 & 26,87 \\
\hline & MédiaC5A & 8,98 & 12,46 & 27,05 \\
\hline & Desvio Padrão & 0,04 & 0,08 & 5,59 \\
\hline & Desvio relativo (\%) & 0,40 & 0,63 & 20,66 \\
\hline
\end{tabular}

\begin{tabular}{|l|}
\hline \multicolumn{1}{|c|}{ Legenda } \\
CP: corpo de prova \\
PF: Perda ao fogo \\
RQ: Retraçāo linear de queima \\
RQ: Retração linear de secagem \\
MRF: Módulo de ruptura à flexão \\
Hprensa: Umidade de prensagem \\
\hline
\end{tabular}

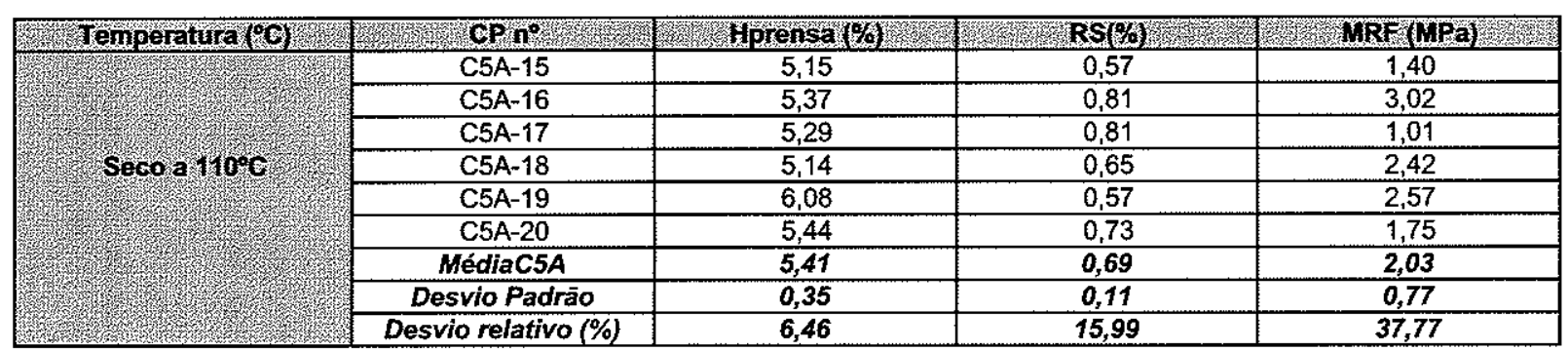


ANEXO 4: Resultados de ensaios cerâmicos: Amostra C5B

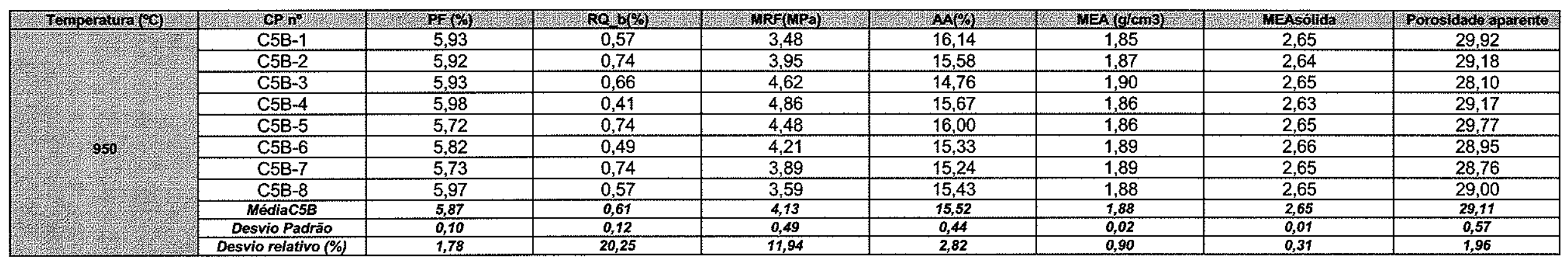

\begin{tabular}{|c|c|c|c|c|c|c|c|c|}
\hline Tenperard ( $C)$ & AP & 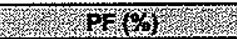 & RQ(\%) & MRF MPa) & $(8 \times(\%)$ & MEA $(g(\mathrm{~min})$ & MEA & $P \alpha(\%)$ \\
\hline \multirow{11}{*}{1100} & C5B-9 & 6,11 & 3,20 & 5,88 & 11,21 & 2,03 & 2,63 & 22,76 \\
\hline & C5B-10 & 5,91 & 3,20 & 7,34 & 11,74 & 2,01 & 2,63 & 23,57 \\
\hline & C5B-11 & 5,90 & 3,03 & 5,52 & 11,15 & 2,03 & 2,63 & 22,64 \\
\hline & C5B-12 & 5,89 & 2,96 & 5,81 & 12,29 & 1,97 & 2,60 & 24,24 \\
\hline & $\mathrm{C} 5 \mathrm{~B}-13$ & 5,91 & 3,03 & 6,55 & 12,66 & 1,96 & 2,61 & 24,82 \\
\hline & C5B-14 & 5,88 & 2,71 & 6,61 & 12,26 & 1,98 & 2,61 & 24,25 \\
\hline & C5B-15 & 5,93 & 2,87 & 6,18 & 11,81 & 2,00 & 2,62 & 23,62 \\
\hline & $\mathrm{C} 5 \mathrm{~B}-16$ & 6,08 & 2,71 & 4,35 & 14,51 & 1,89 & 2,60 & 27,38 \\
\hline & MédiaC5B & 5,95 & 2,96 & 6,03 & 12,20 & 1,98 & 2,62 & 24,16 \\
\hline & Desvio Padrão & 0,09 & 0,19 & 0,89 & 1,07 & 0,05 & 0,01 & 1,50 \\
\hline & Desvio relativo (\%) & 1,51 & 6,49 & 14,69 & 8,76 & 2,35 & 0,43 & 6,21 \\
\hline
\end{tabular}

\begin{tabular}{|c|c|c|c|c|}
\hline Teroperatura $(\mathrm{C})$ & (1) & Horbsa (\%) & RTH & 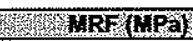 \\
\hline \multirow{11}{*}{ Seroo a $110 \circ \mathrm{C}$} & C5B-17 & 4,35 & 0,57 & 2,06 \\
\hline & C5B-18 & 4,34 & 0,73 & 1,97 \\
\hline & C5B-19 & 4,33 & 0,73 & 2,69 \\
\hline & $\mathrm{C} 5 \mathrm{~B}-20$ & 4,40 & 0,81 & 2,24 \\
\hline & C5B-21 & 4,41 & 0,73 & 2,30 \\
\hline & C5B-22 & 4,33 & 0,65 & 2,33 \\
\hline & C5B-23 & 4,24 & 0,89 & 3,58 \\
\hline & C5B-24 & 4,34 & 0,65 & 2,06 \\
\hline & MédiaC5B & 4,34 & 0,72 & 2,40 \\
\hline & Desvio Padräo & 0,05 & 0,10 & 0,53 \\
\hline & Desvio relativo (\%) & 1,16 & 14,03 & 21,93 \\
\hline
\end{tabular}

Legenda
CP: corpo de prova
PF: Perda ao fogo
RQ: Retração linear de queima
RQ: Retração linear de secagem
MRF: Módulo de ruptura à flexão
AA: Absorção de água
MEA: Massa especifica aparente da parte sólida
MEA: Massa especifica aparente
PA: Porosisade aparente
Hprensa: Umidade de prensagem


ANEXO 4: Resultados de ensaios cerâmicos: Amostra C6V

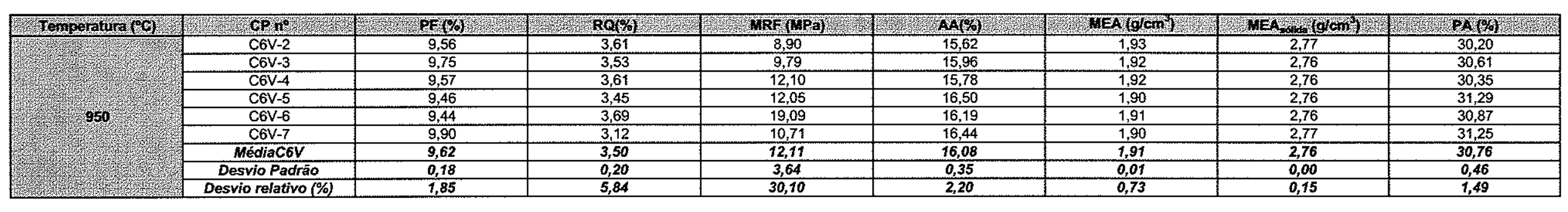

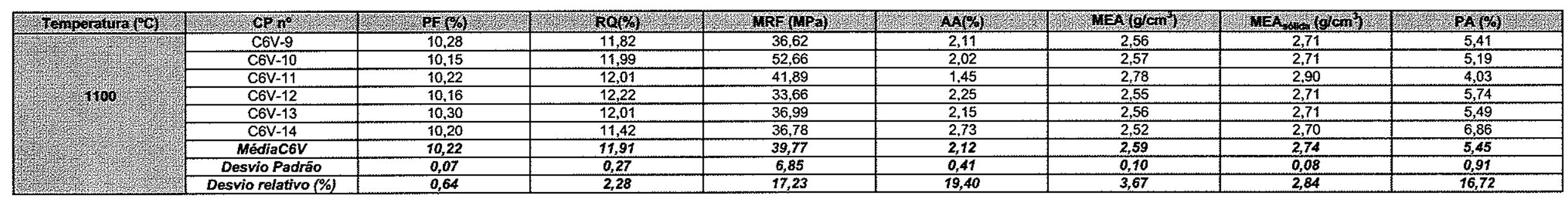

\begin{tabular}{|c|c|c|c|c|}
\hline Temperatura (C) & 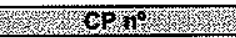 & 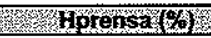 & RS(\%) & MRF (GPa) \\
\hline \multirow{10}{*}{ Seco a 1100} & C6V-8 & 4,98 & 0,33 & 2,21 \\
\hline & C6V-9 & 5,05 & 0,57 & 1,56 \\
\hline & $\mathrm{C} 6 \mathrm{~V}-10$ & 4,88 & 0,57 & 2,39 \\
\hline & $\mathrm{C} 6 \mathrm{~V}-11$ & 4,85 & 0,25 & 3,22 \\
\hline & $\mathrm{C} 6 \mathrm{~V}-12$ & 4,86 & 0,33 & 3,28 \\
\hline & $\mathrm{C} 6 \mathrm{~V}-13$ & 4,87 & 0,57 & 2,27 \\
\hline & $\mathrm{C} 6 \mathrm{~V}-14$ & 4,79 & 0,33 & 3,01 \\
\hline & Médiac6V & 4,90 & 0,42 & 2,56 \\
\hline & Desvio Padrāo & 0,09 & 0,14 & 0,63 \\
\hline & Desvio relativo (\%) & 1,79 & 34,36 & 24,61 \\
\hline
\end{tabular}

Legenda
CP: corpo de prova
PF: Perda ao fogo
RQ: Retraçäo linear de queirna
RQ: Retração linear de secagem
MRF: Módulo de ruptura à flexāo
AA: Absorção de água
MEA: Massa especifica aparente
MEA: Massa específica aparente da parte sólida
PA: Porosisade aparente
Hprensa: Umidade de prensagem


ANEXO 4: Resultados de ensaios cerâmicos: Amostra C11

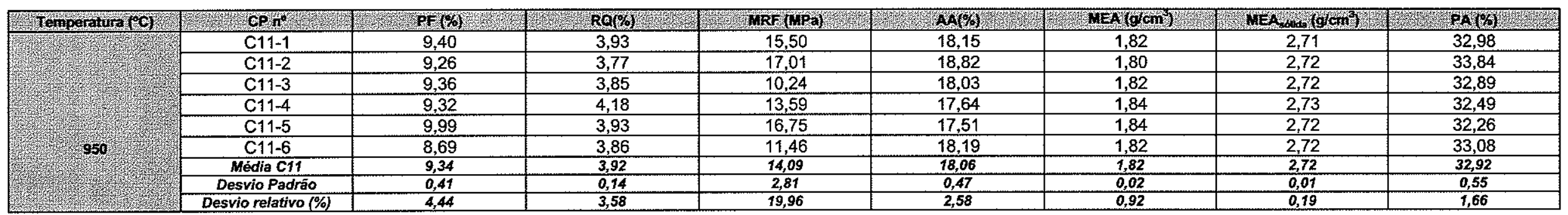

\begin{tabular}{|c|c|c|c|c|c|c|c|c|}
\hline Temporalura $(29$ & CP & $p(p)=2$ & 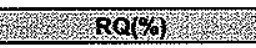 & N & $\mathrm{AA}\left(\mathrm{O}_{0}\right)_{2}$ & NES $(\mathrm{g} / \mathrm{cm} / \mathrm{M}$ & 1EA- in $(9 \mathrm{~cm})$ & S \\
\hline \multirow{8}{*}{1100} & C11-8 & 10,15 & 14,60 & 36,61 & 0.47 & 2,63 & 2,66 & 1,24 \\
\hline & C11-9 & 10,16 & 15,02 & 59,84 & 0,37 & 2,64 & 2,67 & 0.97 \\
\hline & C11-10 & 10,16 & 15,02 & 48,74 & 0,88 & 2,60 & 2,66 & 2,29 \\
\hline & C11-11 & 10,21 & 14,89 & 43,44 & 0,54 & 2,63 & 2,67 & 1,41 \\
\hline & C11-13 & 10,25 & 14,78 & 42,43 & 0,96 & 2,59 & 2,66 & 2,48 \\
\hline & Média C11 & 10,19 & 14,86 & 46,21 & 0,64 & 2,62 & 2,66 & 1,68 \\
\hline & Desvio Padrão & 0,04 & 0,18 & 8,75 & 0,26 & 0,02 & 0,00 & 0,67 \\
\hline & Desvio relativo (\%) & 0,42 & 1,21 & 18,93 & 40,60 & 0,78 & 0,12 & 39,85 \\
\hline
\end{tabular}

\begin{tabular}{|c|c|c|c|c|}
\hline \multirow{7}{*}{$\operatorname{secos} 110 \circ \mathrm{C}$} & 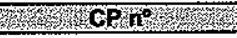 & Hprensa $(\%)$ & STES & H MRE MPa) \\
\hline & $\mathrm{C} 11-16$ & 5,29 & 0,73 & 2,46 \\
\hline & $\mathrm{C} 11-19$ & 5,31 & 0,65 & 3,06 \\
\hline & C11-20 & 6,35 & 0,65 & 3,09 \\
\hline & C11-21 & 5,13 & 0,81 & 3,32 \\
\hline & Média C11 & 5,52 & 0,71 & 2,98 \\
\hline & Desvio Padrāo & 0,56 & 0,08 & 0,37 \\
\hline & Desvio relativo (\%) & 10,13 & 10,91 & 12,35 \\
\hline
\end{tabular}

CP: corpo de prova

PF: Perda ao fogo

RQ: Retração linear de queima

RQ: Retração linear de secagem

AA: Absorção de água

Legenda

MEA: Massa especifica aparente da parte sólida

MEA: Massa especifica aparente

PA: Porosisade aparente

Hprensa: Umidade de prensagem 
ANEXO 4: Resultados de ensaios cerâmicos: Amostra C13B

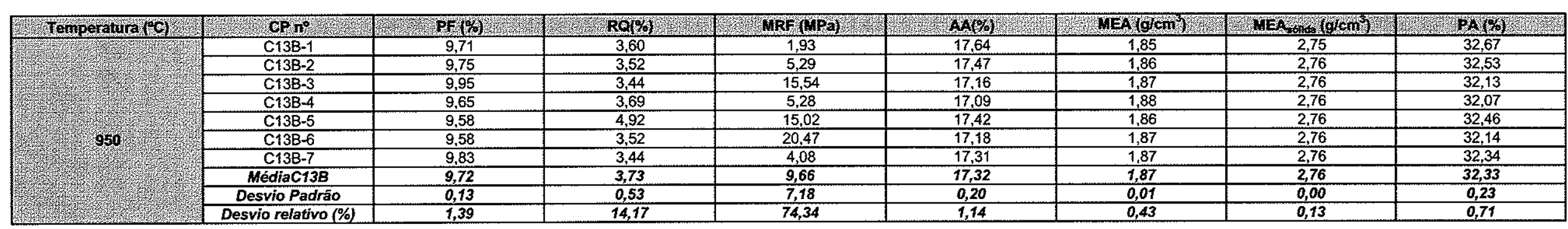

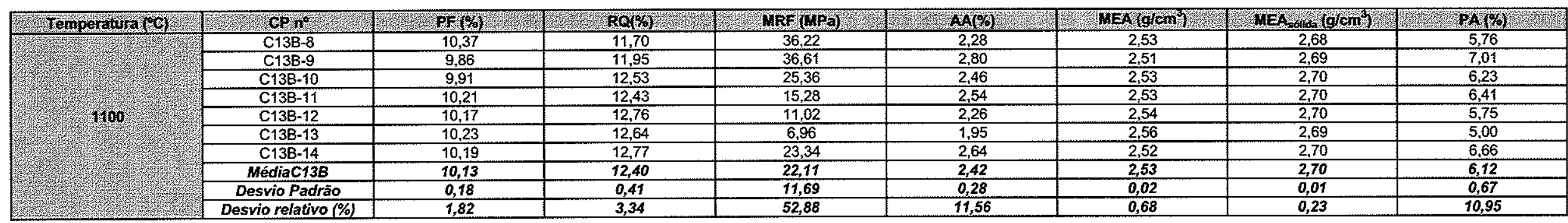

\begin{tabular}{|c|c|c|c|c|}
\hline Temperatura ( $C)$ & CP no: & 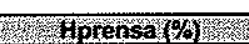 & S RS(\%) & 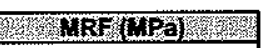 \\
\hline \multirow{9}{*}{ seco a 1100} & $\mathrm{C} 13 \mathrm{~B}-18$ & 5,46 & 0,65 & 3,42 \\
\hline & C13B- 19 & 5,59 & 0,65 & 5,24 \\
\hline & C13B-20 & 5,68 & 0,57 & 4,47 \\
\hline & C13B-21 & 5,65 & 0,49 & 4,72 \\
\hline & C13B-22 & 5,58 & 0,57 & 4,78 \\
\hline & $\mathrm{C} 13 \mathrm{~B}-23$ & $\frac{5,52}{5,52}$ & 0,65 & 5,43 \\
\hline & MédiaC13B & $\frac{5,58}{5,58}$ & 0,60 & 4,68 \\
\hline & Desvio Padrão & 0,08 & 0,07 & 0,71 \\
\hline & Desvio relativo (\%) & 1,42 & 11,03 & 15,21 \\
\hline
\end{tabular}

Legenda

CP: corpo de prova

RO: Perda ao fogo

RQ: Retraçāo linear de secagem

RQ: R :

AA: Absorção de água

MEA: Massa especifica aparente da parte sólida

MEA: Massa especíica aparente

PA: Porosisade aparente

Hprensa: Umidade de prensagem 
ANEXO 4: Resultados de ensaios cerâmicos: Amostra C19

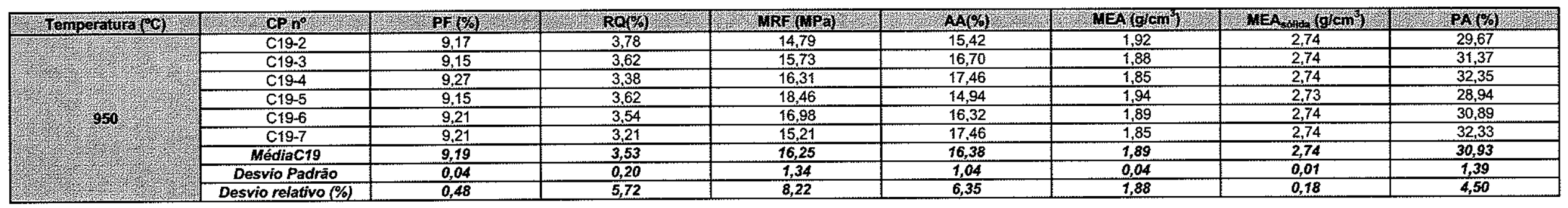

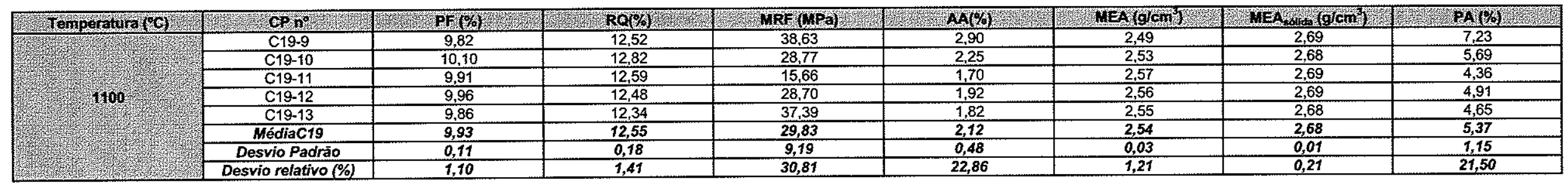

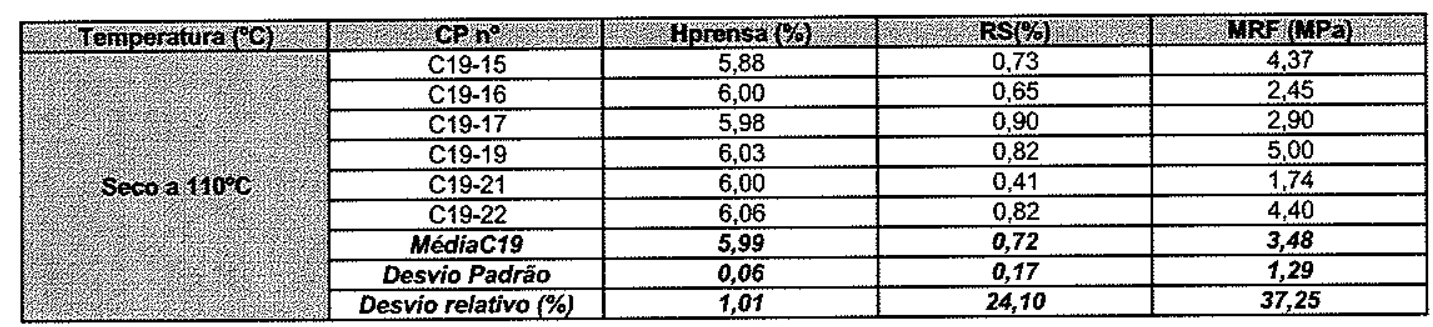

Legenda
CP: corpo de prova
PF: Perda ao fogo
RQ: Retração linear de queima
RQ: Retração linear de secagem
MRF: Módulo de ruptura à flexăo
AA: Absorção de águra
MEA: Massa especifica aparente da parte sólida
MEA: Massa especifica aparente
PA: Porosisade aparente
Hprensa: Umidade de prensagem

